UNIVERSIDADE DE SÃO PAULO

FACULDADE DE FILOSOFIA, LETRAS E CIÊNCIAS HUMANAS

DEPARTAMENTO DE LETRAS CLÁSSICAS E VERNÁCULAS

PROGRAMA DE PÓS-GRADUAÇÃO EM FILOLOGIA E LÍNGUA PORTUGUESA

\title{
Imagens de si no discurso das instituições financeiras nas propagandas em revistas dos séculos XX e XXI: um estudo multimodal
}

\author{
VERSÃO CORRIGIDA
}

LUCIMAR REGINA SANTANA RODRIGUES

SÃO PAULO

2019 


\title{
Imagens de si no discurso das instituições financeiras nas propagandas em revistas dos séculos XX e XXI: um estudo multimodal
}

\author{
VERSÃO CORRIGIDA \\ Tese de Doutorado apresentada ao Departamento de Letras Clássicas e \\ Vernáculas, da Faculdade de Filosofia, Letras e Ciências Humanas, da \\ Universidade de São Paulo, como requisito para obtenção de título de \\ Doutor em Letras. \\ Programa de Pós-Graduação em Filologia e Língua Portuguesa \\ Linha de pesquisa: Linguística Textual e Teorias do Discurso no \\ Português \\ Orientadora: Profa. Dra. Maria Lúcia C. V. O. Andrade
}

SÃO PAULO

2019 
Autorizo a reprodução e divulgação total ou parcial deste trabalho, por qualquer meio convencional ou eletrônico, para fins de estudo e pesquisa, desde que citada a fonte.

Catalogação na Publicação

Serviço de Biblioteca e Documentação

Faculdade de Filosofia, Letras e Ciências Humanas da Universidade de São Paulo

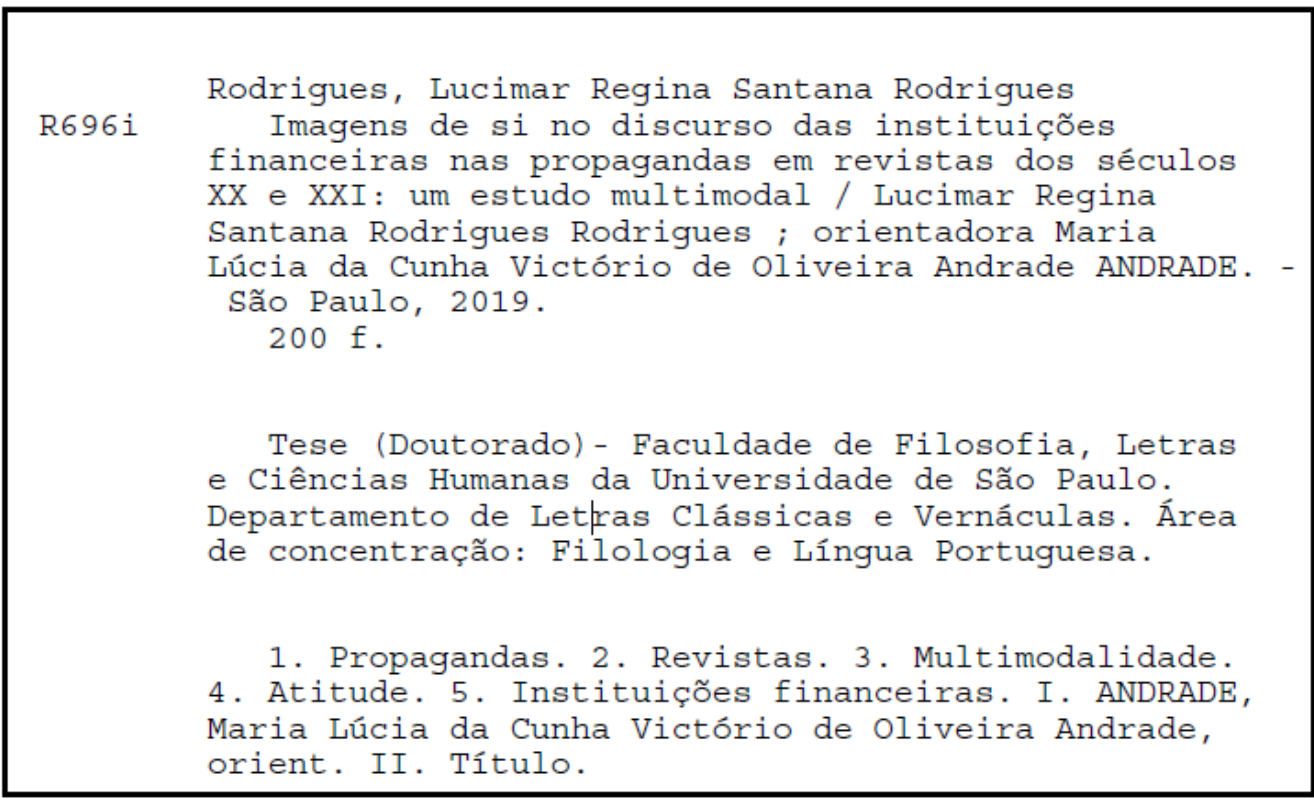




\section{ENTREGA DO EXEMPLAR CORRIGIDO DA DISSERTAÇÃO/TESE}

\section{Termo de Ciência e Concordância do (a) orientador (a)}

Nome do (a) aluno (a): LUCIMAR REGINA SANTANA RODRIGUES

Data da defesa: $\underline{26 / 09 / 2019}$

Nome do Prof. (a) orientador (a): MARIA LÚCIA DA CUNHA VICTÓRIO DE OLIVEIRA ANDRADE

Nos termos da legislação vigente, declaro ESTAR CIENTE do conteúdo deste EXEMPLAR CORRIGIDO elaborado em atenção às sugestões dos membros da comissão Julgadora na sessão de defesa do trabalho, manifestando-me plenamente favorável ao seu encaminhamento e publicação no Portal Digital de Teses da USP.

São Paulo, 25/11/2019

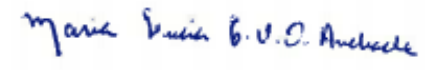


RODRIGUES, L. R. S. Imagens de si no discurso das instituições financeiras nas propagandas em revistas dos séculos XX e XXI: um estudo multimodal. Tese (Doutorado) - Faculdade de Filosofia, Letras e Ciências Humanas, Universidade de São Paulo, 2019.

Tese apresentada ao Programa de PósGraduação em Filosofia e Língua Portuguesa do Departamento de Letras Clássicas e Vernáculas da Faculdade de Filosofia, Letras e Ciências Humanas da Universidade de São Paulo para obtenção do título de Doutor em Letras.

Aprovado em: 26/09/2019

Banca Examinadora

Profa. Dra.Ana Rosa Ferreira Dias

Julgamento: Aprovado

Profa. Dra.Kelly Cristina de Oliveira

Julgamento: Aprovado

Profa. Dra.Paula de Souza G.Morasco

Julgamento: Aprovado
Instituição: FFLCH - USP

Assinatura:

Instituição: IFSP

Assinatura:

Instituição: IFSP

Assinatura: 


\section{AGRADECIMENTOS}

A Deus que sempre iluminou meus caminhos e guiou os meus passos.

À minha orientadora, professora doutora Maria Lúcia da Cunha Victório de Oliveira Andrade, obrigada pela dedicação, pelo empenho e, principalmente, pelo carinho e conforto em todo o meu percurso na Universidade de São Paulo, desde o mestrado.

À professora Dra. Paula de Souza Gonçalves Morasco, pela gentileza, pela disponibilidade e contribuições feitas na minha qualificação.

À professora Dra. Kelly Cristina de Oliveira, pela amizade que perdura desde o início do processo do nosso mestrado, pela companhia nos eventos e por ser um exemplo de vida de conquistas.

À professora Dra.Ana Rosa Ferreira Dias, agradeço pela disponibilidade e dedicação à leitura de minha tese e pela presença em minha defesa. É uma honra tê-la conosco nesse momento ímpar. Gratidão.

À querida Célia Araes, que, mais que uma amiga, considero minha irmã, que me acompanha e protege sempre, independentemente das dificuldades e perdas pelas quais tenha passado em todo o nosso tempo de amizade.

A todos os colegas que foram e ainda são orientandos da nossa querida Maria Lúcia, pois nos tornamos uma grande família, que estuda e se diverte juntos.

Aos meus pais Valdir e Edith, por terem me indicado o caminho, aos meus irmãos Dolores e Idair, por caminharem sempre junto comigo, ao meu esposo Márcio, pelo incentivo e companhia sempre, aos meus filhos Ana Paula e Caio, pela compreensão pelas minhas ausências e, aos meus dois anjinhos Valdirene e Thiago que, com certeza, estão me olhando lá do infinito.

À amiga revisora Marilu, pelo olhar que tanto contribuiu com os meus textos e que faz parte desta conquista. 


\section{RESUMO}

RODRIGUES, L. R. S. Imagens de si no discurso das instituições financeiras nas propagandas em revistas dos séculos $\mathbf{X X}$ e XXI: um estudo multimodal. Tese (Doutorado) - Faculdade de Filosofia, Letras e Ciências Humanas, Universidade de São Paulo, 2019.

Esta pesquisa tem o objetivo de analisar o discurso das instituições financeiras em propagandas publicadas em revistas impressas direcionadas a públicos distintos, no Brasil, no decorrer dos séculos XX e XXI, mostrando como esses discursos vão se construindo e se transformando no decorrer do tempo e das mudanças da sociedade. $O$ corpus compreende propagandas da marca sequencial Banco da Lavoura - Banco Real - Banco Santander publicadas, dos anos 1960 até 2018, nas revistas Claudia, Veja e Exame - direcionadas a diferentes segmentos da sociedade: público feminino, público geral e público executivo, respectivamente. A escolha por propagandas de bancos justifica-se pelo fato de se tratar de instituições pertencentes à área de economia e finanças - uma fatia do mercado que acreditamos ser marcada pela objetividade, lógica e, consequentemente, frieza nas relações interpessoais, que se confronta com a propaganda cuja finalidade é seduzir e encantar o consumidor. A partir das perspectivas da multimodalidade, realizamos as análises com base nos processos e categorias da gramática do design visual, de Kress e Van Leeuwen (2006), somados aos postulados da cena enunciativa de Maingueneau (2013) e do sistema da valoração ou avaliatividade de Martin e White (2005). Considerando o papel crucial da propaganda e seu poder de persuasão e sedução, somam-se à fundamentação teórica Charaudeau (2010), Sandmann (2012) e Amossy (2018). Com o intuito de compreender o contexto sóciohistórico-econômico em que os discursos das instituições financeiras estavam inseridos no decorrer das seis décadas mencionadas, contamos com a contribuição de autores como Brandão (1995) e Fausto (2006). As análises mostram que os recursos verbais e imagéticos têm igual importância na construção da imagem das instituições financeiras; que a seleção desses recursos se transforma no decorrer do tempo e se diferencia quando direcionados a leitores diferentes (geral, feminino, executivo) e que as instituições financeiras selecionadas para esta pesquisa buscam construir com o público-alvo leitores das revistas impressas - uma relação pautada nos valores atitudinais de afeto.

Palavras-chave: Propagandas; Revistas; Multimodalidade; Afeto; Instituições financeiras 


\begin{abstract}
RODRIGUES, L.R.S. Images of itself in the discourse of financial institutions in advertisements by $20^{\text {th }}$ and $21^{\text {st }}$ century magazines: a multimodal study. Thesis (Doctorate) - Faculdade de Filosofia, Letras e Ciências Humanas, Universidade de São Paulo, 2019.
\end{abstract}

This research aims to analyze the discourse of financial institutions in advertisements published in printed journals directed to various kinds of audiences. Over the course of the twentieth and twenty-first centuries, Brazilian financial institutions' advertisements have shown how this kind of discourse was built and altered throughout time, and how it led to changes in society. This corpus, which includes pieces of advertisement published from the 1960s to 2018, comprises of the following associations: Banco da Lavoura, Banco Real and Banco Santander. We also analyzed advertisements published in the magazines Claudia, Veja and Exame, which were directed to audiences from numerous segments of society: female public, public in general and executive public, respectively. The selection of banks' advertisements is justified by the fact that they are institutions that are part of the economics and finance field - a market share that we believe to be permeated with objectivity, logic and thus a cold behavior towards interpersonal relationships. Additionally, announcements that have the intent to seduce and enchant consumers are regularly faced by these interpersonal relationships. From the perspective of Multimodality, we performed the analyses based on the processes and categories of the visual design grammar by Kress and Van Leeuwen (2006), then added the system of valuation or evaluation by Martin and White (2005) to the postulates of the enunciative scene by Maingueneau (2013). Considering the crucial role of propaganda and its power of persuasion and seduction, we added the theoretical foundation Charaudeau (2010), Sandmann (2012) and Amossy (2018). In order to understand the social, historical and economic context in which these genres of discourse from financial institutions were inserted, taking into consideration those six decades indicated, we relied on the contributions of authors such as Brandão (1995) and Fausto (2006). The analyses showed that the verbal and imagetic resources have equivalent importance in the construction of the financial institutions' ethos. Furthermore, it showed that the selection of those resources had been altered throughout time and differed when directed to specific readers (general, feminine, executive, e.g.). Apart from that, it was explained that the financial institutions chosen for this research sought to build a relationship based on the attitudinal values of affection with their target audience, the readers of printed journals.

Keywords: Advertisements; Magazines; Multimodality; Affection; Financial institutions 


\section{LISTA DE FIGURAS}

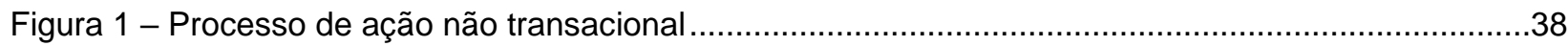

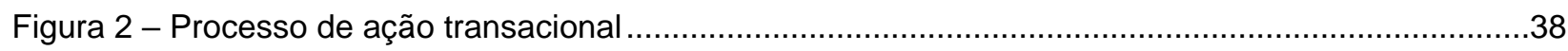

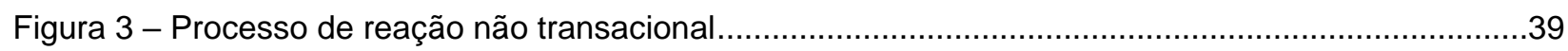

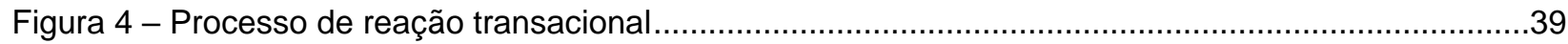

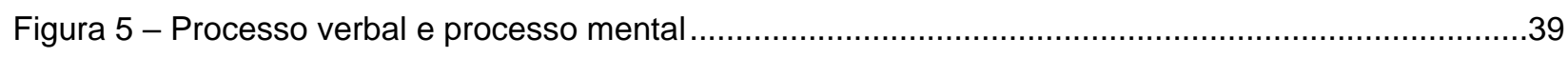

Figura 6 - Processo classificatório implícito …............................................................................ 40

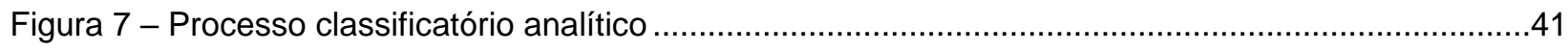

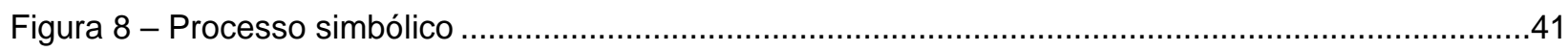

Figura 9 - Contato - demanda

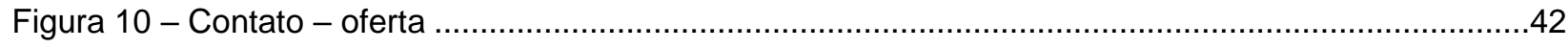

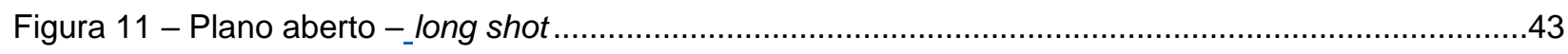

Figura 12 - Plano médio - medium shot ……................................................................................

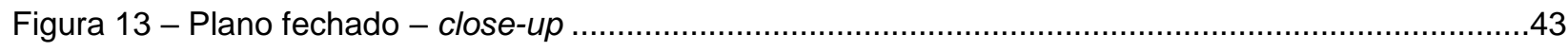

Figura 14 - Ângulo frontal - relação de proximidade ..................................................................43

Figura 15 - Ângulo oblíquo - médio distanciamento ......................................................................43

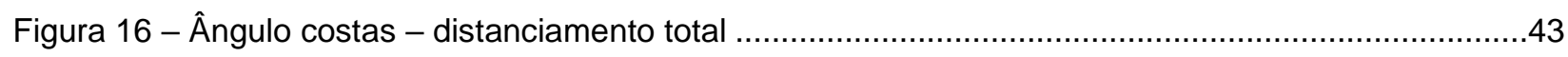

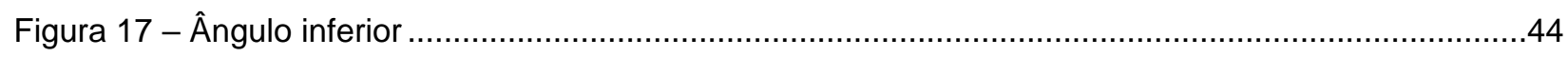

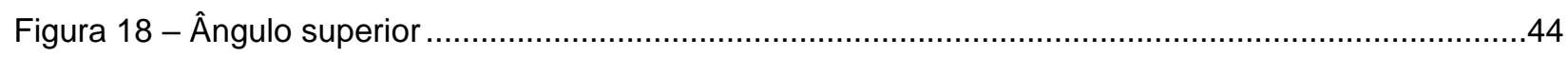

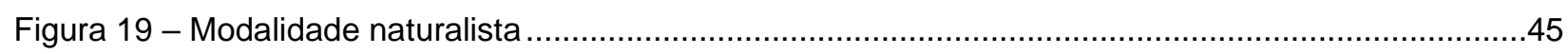

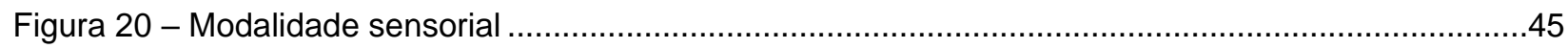

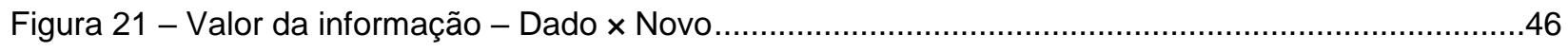

Figura 22 - Valor da informação - Ideal $\times$ Real ........................................................................47

Figura 23 - Valor da informação - Principal $\times$ Marginal ...................................................................47

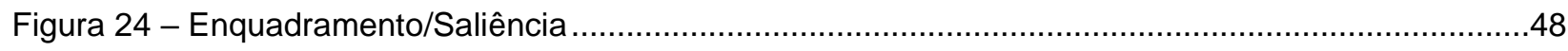

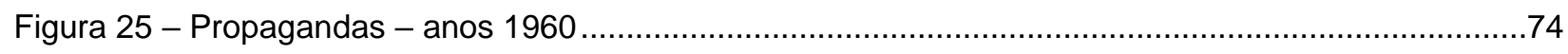

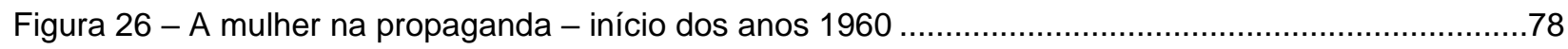

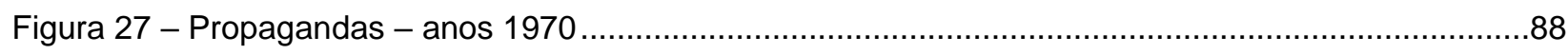

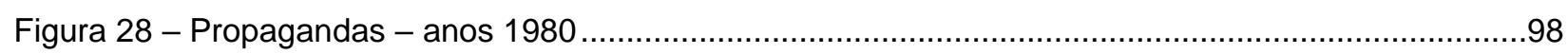

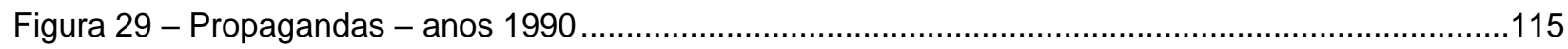

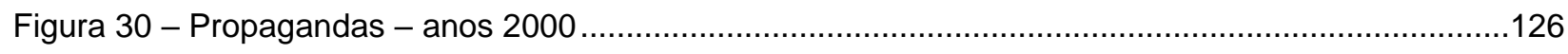

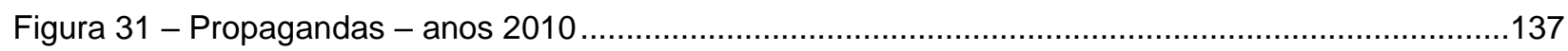




\section{LISTA DE QUADROS}

Quadro 1 - Organização metafuncional da linguagem: contexto, atividade e sistema ............. 35 Quadro 2 - Visão das funções e categorias da gramática visual por Kress e van Leeuwen ..... 37

Quadro 3 - Classificação do afeto em seis fatores ........................................................... 59

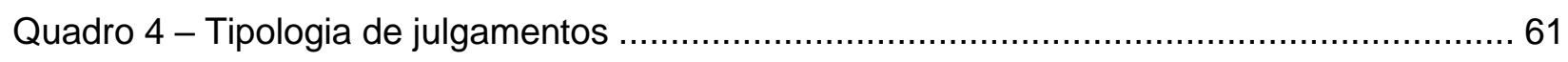

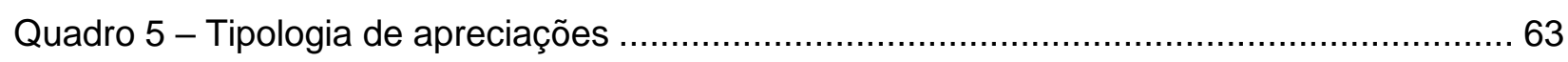




\section{LISTA DE ABREVIATURAS}

$\begin{array}{ll}\text { OR } & \text { Obrigações rodoviárias } \\ \text { GDV } & \text { Gramática do design visual } \\ \text { LSF } & \text { Linguística sistêmico-funcional } \\ \text { GSF } & \text { Gramática sistêmico-funcional } \\ \text { PME } & \text { Pequenas e médias empresas } \\ \text { CPD } & \text { Centro de Processamento de Dados } \\ \text { TI } & \text { Tecnologia da informação } \\ \text { Febraban } & \text { Federação Brasileira de Bancos }\end{array}$




\section{SUMÁRIO}

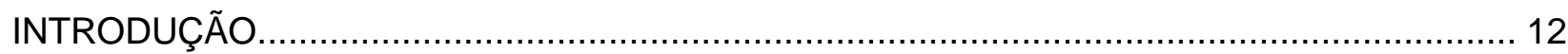

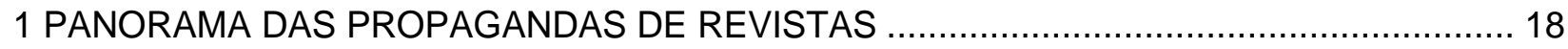

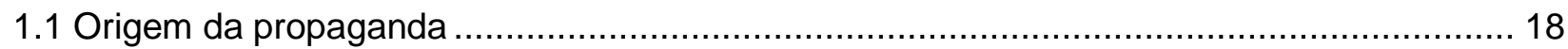

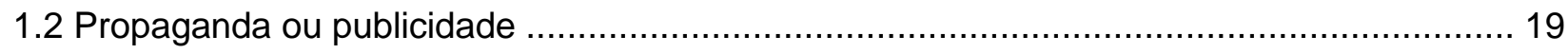

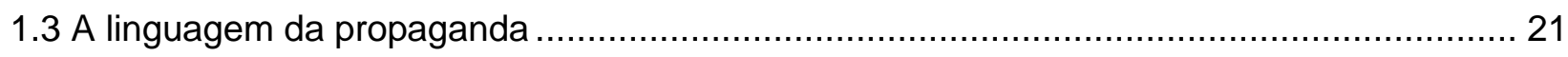

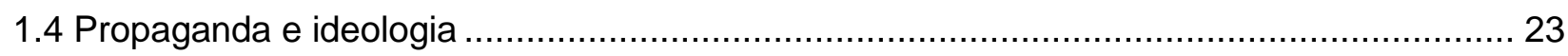

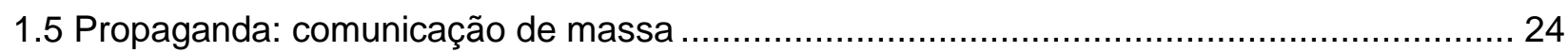

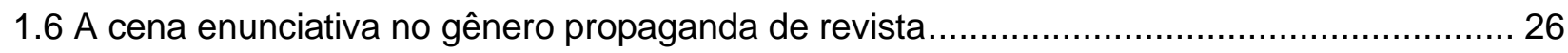

2 A MULTIMODALIDADE NAS PROPAGANDAS EM REVISTAS IMPRESSAS …................... 31

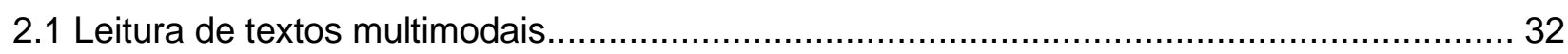

2.2 As categorias das estruturas visuais de Kress e van Leeuwen ........................................ 33

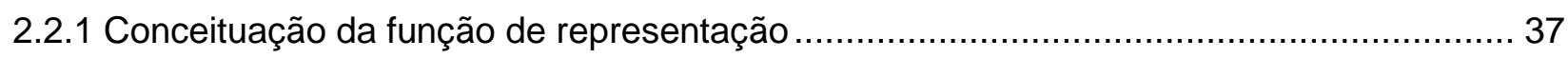

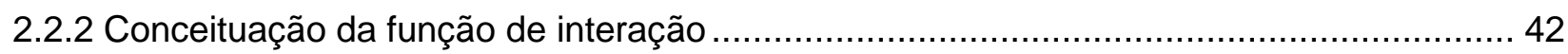

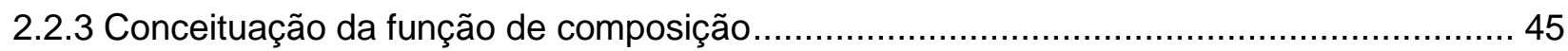

3 A CONSTRUÇÃO DA IMAGEM NOS DISCURSOS DAS INSTITUIÇÕES FINANCEIRAS EM

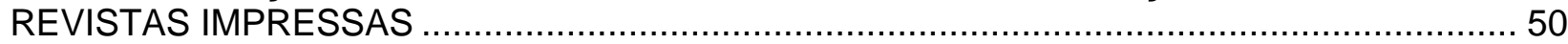

3.1 A imagem que o (hoje) Banco Santander faz de si mesmo............................................ 51

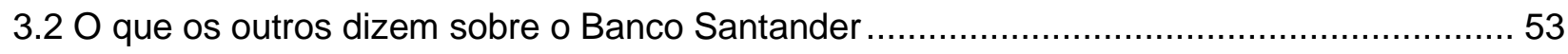

3.3 A argumentação no discurso das instituições financeiras nas propagandas ....................... 54

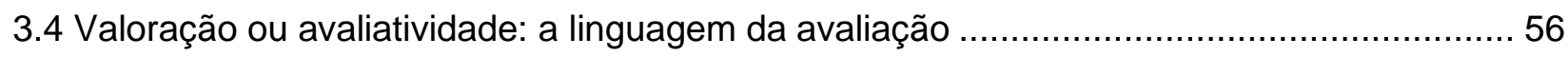

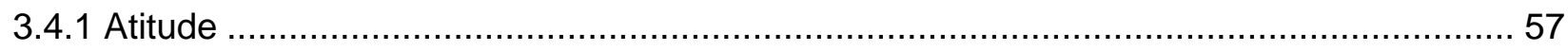

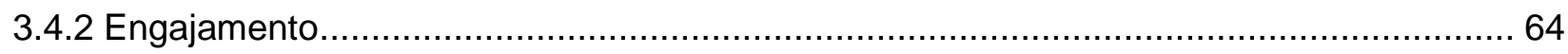

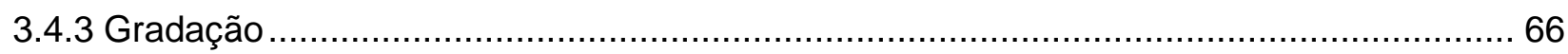

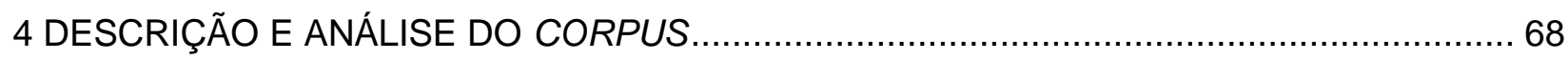

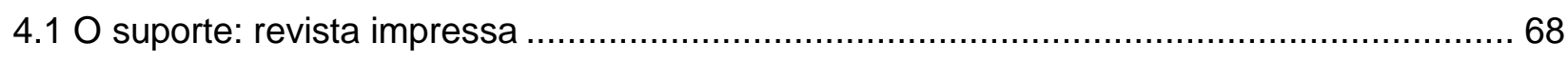

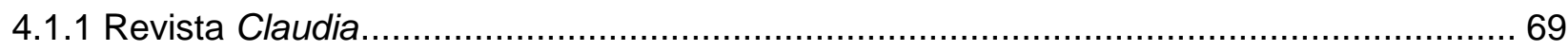

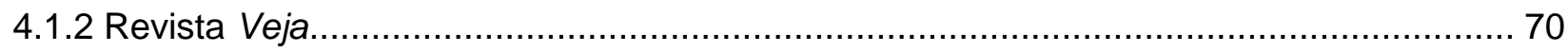

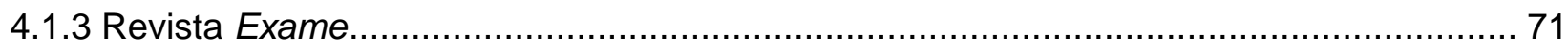

4.2 Propagandas de instituições financeiras em revistas dos séculos XX e XXI: análise do corpus 72

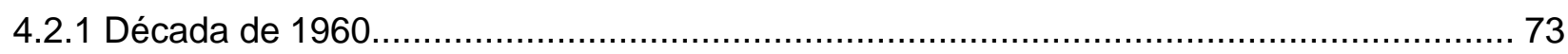

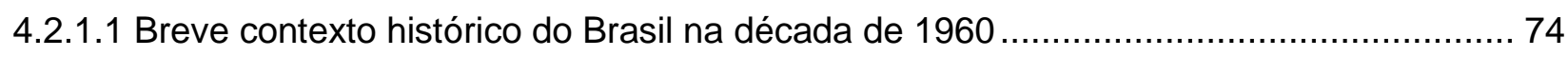

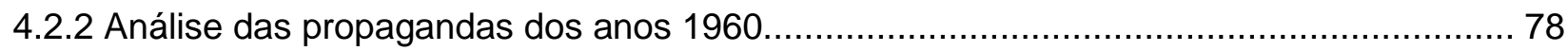

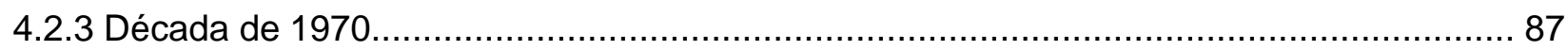

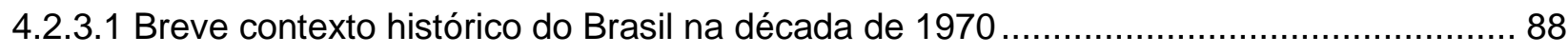




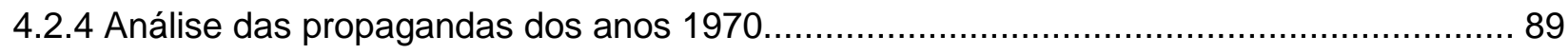

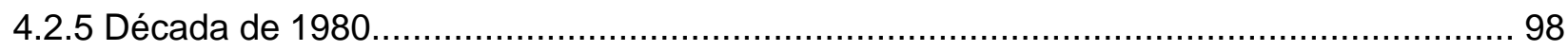

4.2.5.1 Breve contexto histórico do Brasil na década de 1980: uma década promissora para as

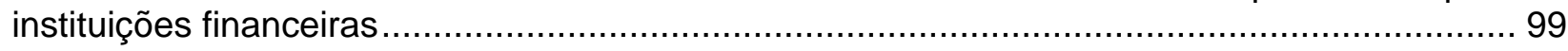

4.2.5.2 Anos 1980: tempos de aberturas e de planos econômicos ...................................... 101

4.2.6 Análise das propagandas dos anos 1980....................................................... 102

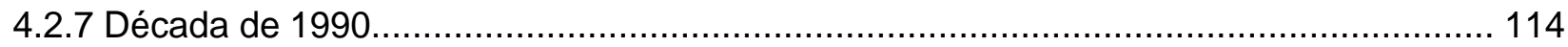

4.2.7.1 Breve contexto histórico do Brasil e das instituições financeiras na década de 1990 .. 116

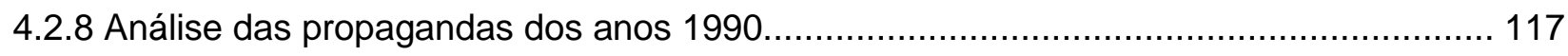

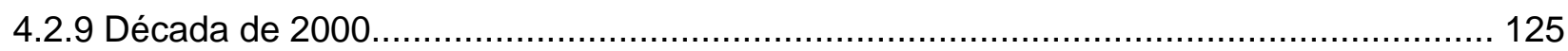

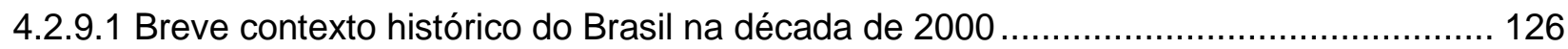

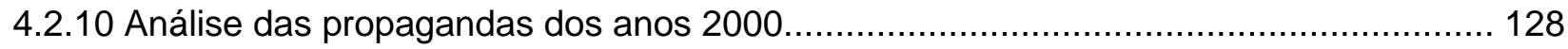

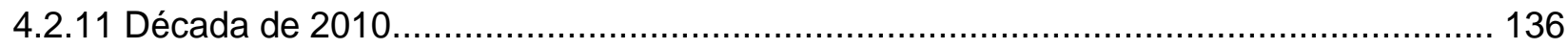

4.2.11.1 Breve contexto histórico do Brasil na década de 2010 ........................................ 137

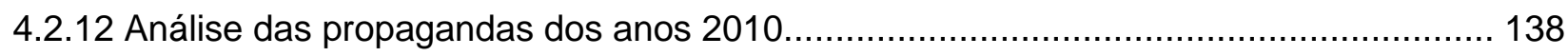

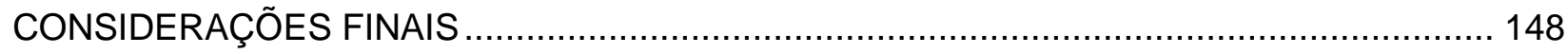

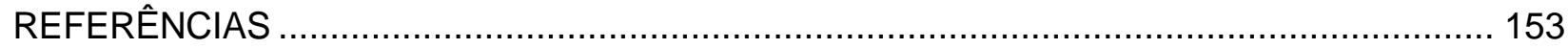

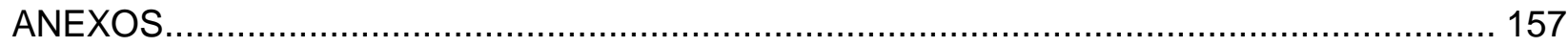




\section{INTRODUÇÃO}

A partir de um cuidadoso levantamento de recursos da linguagem verbal e visual, pretende-se desenvolver uma análise multimodal diacrônica de propagandas veiculadas em revistas impressas das décadas 60, 70, 80, 90, 2000 e 2010.

O objetivo geral desta tese é contribuir para o aprofundamento das análises de propagandas de instituições financeiras publicadas em revistas impressas direcionadas a públicos diversos, no Brasil, no decorrer dos séculos $\mathrm{XX}$ e $\mathrm{XXI}$, mostrando como os discursos de tais instituições vão se construindo e se transformando no decorrer do tempo e das mudanças da sociedade.

Os objetivos específicos são:

- Levantar os recursos multimodais utilizados pelos anunciantes para a construção da imagem institucional do Banco da Lavoura - Banco Real - Banco Santander em revistas dos anos 1960 a 2018.

- Analisar as estratégias utilizadas para a construção da imagem e sua identificação com o público-alvo, leitores de revistas, publicadas nos séculos XX e XXI;

- Investigar a relação construída entre a instituição financeira e o cliente do banco a partir do binômio identificação e atitude, levando em consideração a visada intenção de atrair e fidelizar o cliente, criando uma imagem institucional positiva.

O corpus selecionado incorpora propagandas das marcas sequenciais - Banco da Lavoura / Banco Real / Banco Santander, desde a década de 1960 até o final da década de 2010, publicadas em revistas de circulação nacional, ou seja, abrange sessenta anos de três revistas - Claudia, Veja e Exame - direcionadas a públicos de diferentes segmentos da sociedade: público feminino, público geral e público executivo, respectivamente.

A escolha por propagandas de instituições financeiras justifica-se pelo fato de se tratar de instituições relacionadas à área de economia e finanças - uma fatia do mercado supostamente marcada pela frieza nos relacionamentos interpessoais - que se confronta com a propaganda, cuja finalidade é seduzir/encantar o consumidor e criar opinião favorável a um determinado serviço ou produto. Diante disso, lançamo-nos aos seguintes 
problemas de pesquisa: Qual é a imagem que se pretende construir das instituições financeiras nas propagandas de revistas impressas? Que recursos multimodais (verbais e visuais) são utilizados para a construção dessa imagem nas propagandas? O contexto sócio-histórico-econômico influencia a seleção de recursos para a construção dessa imagem? O meio de comunicação/público-alvo interfere na seleção de recursos utilizados para a construção da imagem das instituições financeiras nas propagandas em revistas?

Com o intuito de responder a essas questões, o trabalho tem como base teórica os seguintes autores: Martin e White (2005), Kress e van Leeuwen (2006), Sandmann (2012), Maingueneau (2013); Amossy (2018), dentre outros. A sustentação desta pesquisa está nas categorias multimodais da gramática do design visual, contribuirão também para as análises outras teorias como: o sistema da valoração ou avaliatividade,; o discurso da mídia e a linguagem da propaganda; a construção da imagem e aspectos da argumentação e do discurso e, ainda, tópicos da teoria da enunciação, permeados pela evolução do tempo e da sociedade brasileira, no decorrer das décadas 1960 a 2018.

Esta investigação insere-se no Projeto para a História do Português Brasileiro, cujo objetivo é pesquisar nossa língua, historiando-a amplamente em seus sistemas gramatical, lexical, semântico e textual, estudados a partir de dados constantes de um amplo corpus diacrônico, editado com rigor filológico, do qual faz parte a Profa. Dra. Maria Lúcia C. V. O. Andrade, orientadora desta pesquisa.

Entende-se por propaganda a técnica de criar opinião pública favorável a um determinado produto, serviço, instituição ou ideia, visando a orientar o comportamento humano num determinado sentido.

De um lado, as publicações impressas, em geral, sempre foram pontos de venda atraentes para muitos anunciantes, especialmente os que oferecem produtos que visam aos grandes grupos de consumidores. Por outro lado, a tendência geral na propaganda é cada vez mais abandonar os jornais e as revistas privilegiando a TV e a internet, porém, se hoje as empresas estão buscando maneiras diferenciadas, e mais objetivas, de atrair o público, podemos observar que, em décadas passadas, anunciar em uma revista de grande circulação era sinônimo de caminho certo para o sucesso empresarial.

Uma grande quantidade de páginas das revistas era tomada por propagandas, feitas por empresas dos mais diversos segmentos, inclusive instituições financeiras. Em 
artigo relativo às propagandas na Claudia, as autoras Rossini, Tissiane e Oliveira Filha (2011) mensuraram que, das 190 páginas da revista, 31\% destinavam-se a propagandas de páginas inteiras, além daquelas que ocupavam parte das páginas, somadas ainda às chamadas propagandas indiretas, que fornecem orientação de moda, maquiagem e determinadas peças de roupa com as referências de preço e local de venda, ou seja, mais de $50 \%$ das páginas das revistas são ocupadas por propagandas.

As propagandas veiculadas em revistas impressas são constituídas por textos verbais e por recursos visuais (gráficos, tabelas, desenhos, fotografias etc.), resultando portanto, em comunicação multimodal, mais eficiente para atingir os objetivos emergenciais da propaganda: persuadir e seduzir o público leitor.

As teorias relacionadas à multimodalidade são significativas nos estudos que envolvem propagandas impressas. O design do texto e do discurso das propagandas surge como uma preocupação importante, posto que a oferta de mídias e objetos de leitura se ampliam e se diversificam em dispositivos e em modos de produção. De acordo com Ribeiro (2016, p. 33):

Os textos jornalísticos circulam após terem sido objeto de um design complexo e evidentemente multimodal. Texto, leiaute, imagens e gráficos se articulam, de forma a constituir um design que pauta o dia a dia de nossa sociedade. Cada vez mais essa multimodalidade se evidencia, não apenas porque se deseja informar o leitor (influenciá-lo, convencê-lo e mesmo confundi-lo), mas também porque os recursos técnicos capazes de imprimir (ou publicar) imagens, textos e cores foram se aperfeiçoando, especialmente ao longo do século XX.

As propagandas são compostas por textos cuidadosamente diagramados, por imagens, por cores que chamam a atenção e despertam a curiosidade e o interesse do leitor. Acrescenta a autora (2016, p. 34) que "a escolha do leiaute, das cores, da hierarquia das informações desenha uma página e um discurso", isso confirma a relevância dos estudos da multimodalidade para as análises das características da linguagem das propagandas das instituições financeiras, publicadas em revistas, selecionadas para este estudo.

Interessa-nos, especificamente, as propagandas do Banco da Lavoura de Minas Gerais, fundado em 1925, com sede em Belo Horizonte, que, em 1971, mudou de nome para Banco Real e, em 2008, foi adquirido pelo grupo espanhol Santander. Em 2010, todas as agências do Banco Real assumiram a marca Santander em suas fachadas e processos. 
Nos discursos dos anunciantes evidenciados nas propagandas das instituições financeiras, nota-se com clareza, não só uma enorme preocupação de construir uma imagem positiva a partir dos textos representados pela seleção do léxico e de imagens, mas também e, principalmente, a busca pela identificação do anunciante com os valores do seu público-alvo ${ }^{1}$, e, consequentemente, transmitir sua confiabilidade. Ao se mostrar próximo do público alvo, valorizando as escolhas, cultivando os mesmos valores, o anunciante ganha identificação e confiabilidade. À medida que o mundo vai evoluindo e as pessoas vão assumindo outros valores, os anunciantes também vão alterando seus discursos veiculados nas propagandas.

A seleção das propagandas deu-se pela marca do grupo institucional, extensiva, portanto, a todos os produtos e serviços comercializados pelo Banco da Lavoura (anos 1960), Banco Real (anos 1970 a 2008) e Santander (2008 a 2018). Optamos pelas revistas Claudia, lançada em 1961, Veja, lançada em 1968, e Exame, lançada em 1967, todas editadas até os dias atuais. Da década de 1960 à década de 2018, selecionamos propagandas colhidas nas três revistas, podendo, assim, traçar paralelos entre propagandas publicadas em revistas direcionadas a públicos diferentes, a fim de constatar alterações relevantes nos discursos nelas contidos, considerando a hipótese de ocorrerem tais alterações. A seleção do período de sessenta anos (de 1960 a 2018) se deu por permitir a análise de três títulos diferentes de revistas direcionadas a públicos distintos, favorecendo, inclusive a possibilidade de traçarmos paralelos entre textos de final de um século $(X X)$ e início de outro $(X X I)$ da história da propaganda e das instituições financeiras no Brasil.

As propagandas foram coletadas tanto das homepages quanto das versões impressas de revistas pesquisadas na Hemeroteca da Biblioteca Mario de Andrade, na Biblioteca da Faculdade de Economia e Administração (FEA/USP) e na Biblioteca da Fundação Getúlio Vargas (FGV/SP), postadas e publicadas no período indicado. O corpus é composto de três propagandas por década, entre o final dos anos 1960 e o final de 2018, totalizando dezoito textos multimodais das instituições Banco da Lavoura, Banco Real e Banco Santander, que nomeamos como P1, P2 (Propaganda 1,

\footnotetext{
${ }^{1}$ Quando nos referimos às instituições financeiras e a seus clientes/futuros clientes, utilizamos os termos "anunciantes" e "leitores/público alvo", no entanto, preservamos as terminologias advindas das teorias apresentadas como: enunciador/coenunciador; locutor/alocutário; autor/leitor dentre outros.
} 
Propaganda 2), e assim sucessivamente. Utilizamos também outras dezenove propagandas das mesmas instituições que ilustram as categorias da gramática visual ou servem para exemplificações outras, nomeadas figuras (Figura 1, Figura 2, e assim sucessivamente), totalizando trinta e sete, sendo dezenove veiculadas na revista Veja, oito na Claudia, oito na Exame e duas não identificadas nos sites.

Entendemos que a quantidade de textos e a periodicidade relacionadas sejam suficientes para observar mudanças significativas nos discursos das instituições financeiras e na construção de uma imagem que busca identificação e confiabilidade, visando a atrair clientes e à criação de uma imagem institucional positiva.

A metodologia prevê uma pesquisa sócio-histórica das décadas analisadas e a inserção das instituições financeiras nesses períodos, em função disso, somam-se às bases teóricas já mencionadas autores como Brandão (1995) e Fausto (2006). Outros autores ainda como Gregolin (2003), Dionísio (2005), Wolf (2009), Nascimento, Bezerra e Heberle (2011), Bonifácio (2011), Ribeiro (2016), Almeida (2016), Kersch, Coscarelli e Cani (2016), também são relevantes para a análise do corpus que permeia esta pesquisa.

O trabalho está dividido em quatro capítulos, assim denominados: (1) Panorama das propagandas de revistas; (2) A multimodalidade nas propagandas em revistas impressas; (3) A construção da imagem nos discursos; (4) Descrição e análise do corpus.

O Capítulo 1 mostra um panorama das propagandas publicadas em revistas, parte da origem do termo propaganda e discute os termos empregados por autores como Sant'anna (1981), Garcia (1982) e Sandmann (2012), que se dividem entre propaganda e publicidade, e apresenta nossa opção por aquele que também é utilizado pelas revistas selecionadas para o corpus, que é propaganda. O mesmo capítulo também descreve o papel da linguagem no gênero propaganda como comunicação de massa e veículo de ideologias de classes e épocas, abordando ainda a cena enunciativa na propaganda, pela perspectiva de Maingueneau (2013).

O Capítulo 2 centra-se nos estudos da multimodalidade como estratégias de produção e leitura de textos a partir das estruturas da gramática do design visual de Kress e van Leeuwen (2006). Sentiu-se, então, a necessidade de descrever brevemente as metafunções da linguística sistêmico-funcional e apresentar as possíveis relações entre estas categorias verbais e aquelas categorias visuais. 
O Capítulo 3, assim como o anterior, destina-se à fundamentação teóricometodológica que embasa as análises desta tese. Nele, realiza-se um estudo sobre a construção da imagem das instituições financeiras nos discursos veiculados nas propagandas em revistas impressas, a partir de pressupostos da argumentação e do sistema da valoração (ou avaliatividade).

O Capítulo 4 destina-se, enfim, à descrição e análise do corpus - propagandas impressas em três revistas de seis décadas. Busca-se aqui realizar um levantamento de recursos lexicais e visuais no intuito de mostrar possíveis mudanças na imagem institucional construída com os leitores a partir da identificação e da atitude, numa perspectiva sócio-histórica.

Nas Considerações finais, apresentamos um balanço de todo o trabalho, desde a introdução até as análises, remetendo às conclusões obtidas com a pesquisa.

Em seguida, relacionamos as referências e disponibilizamos os anexos, que compreendem todas as propagandas analisadas e também aquelas que serviram somente para exemplificações no decorrer desta tese. 


\section{PANORAMA DAS PROPAGANDAS DE REVISTAS}

"As mídias desempenham o papel de mediação entre os leitores e a realidade" (GREGOLIN, 2003, p. 97). A mídia amplia as visões e diminui as distâncias, ela transforma o individual em coletivo, "participa ativamente, na sociedade atual, da construção do imaginário social, no interior do qual os indivíduos percebem-se em relação a si mesmos e em relação aos outros" (p. 97). Gregolin afirma ainda que "dessa percepção vem a visualização do sujeito como parte de uma coletividade" (p. 97).

A diversidade de imagens que circula na mídia, segundo Gregolin (2003, p. 104), "insere-se no processo sócio-histórico de produção de sentidos, no interior do qual as relações são fecundadas pelas instituições produtoras de textos, que realizam o trabalho significante da cultura".

As revistas são importantes suportes midiáticos e as propagandas que circulam nas revistas fazem parte do relevante processo histórico e social de produção de sentidos tanto dos indivíduos quanto da sociedade em que vivemos.

\subsection{Origem da propaganda}

O termo propaganda origina-se do nome de uma congregação criada em Roma, em 1622, Congregatio de propaganda fide, ou seja, "Congregação da fé que deve ser propagada", ou ainda, "pela propagação da fé". O termo tem origem também na palavra francesa propagande, que significa propagar, multiplicar, aumentar (SANDMANN, 2012)

De acordo com Childs (1967, p. 96):

A expansão da democracia e a extensão do sufrágio, o aumento das facilidades educacionais e da alfabetização, a evolução tecnológica no campo das comunicações, as transformações econômicas, tanto na produção quanto na distribuição e no consumo de riquezas, bem como o ritmo crescente das modificações sociais e a necessidade cada vez maior de cooperação social, tudo isso afetou grandemente o papel da propaganda na sociedade. O significado histórico da propaganda é maior quando ela é executada sistemática e duradouramente por grupos amplos e bem organizados. 
Assim como a sociedade se transformou, alterando desde a maneira de se vestir até a maneira de se comportar e de conviver no trabalho e em família, a propaganda também foi se modificando, dando origem a novos significados. Deixou de ser de uso exclusivo da divulgação da fé para transmitir outras novas ideias de instituições políticas, governamentais, econômicas, sociais. Passou a desempenhar um importante papel no nosso meio, nas mais diferentes atividades da sociedade.

Observa-se que o significado de propaganda pode diferir de acordo com a origem das línguas. Em inglês, o termo propaganda é usado para propagação de ideias, mais especificamente, ideias políticas. Em alemão, propaganda é de ideias, pois, para anúncio, eles usam o termo reklame, emprestado do francês.

\subsection{Propaganda ou publicidade}

A primeira questão a ser levantada é quanto ao emprego dos termos propaganda e publicidade. Verifica-se uma grande polêmica em torno desses termos, pois há autores que os distinguem atribuindo sentidos diferentes para cada um deles, enquanto outros não fazem distinção e os aplicam como sinônimos.

O Dicionário eletrônico Houaiss da língua portuguesa descreve os termos da seguinte forma:

\section{propaganda}

substantivo feminino

1. divulgação de uma ideia, crença, religião

Ex.: trabalho de p. da Igreja católica

2. ação de exaltar as qualidades para um grande número de pessoas

Exs.: fazer $p$. de um candidato

a p. é a alma do negócio

3. Rubrica: publicidade.

difusão de mensagem verbal, pictórica, musical etc., de conteúdo informativo e persuasivo, em TV, jornal, revista etc.; publicidade

Ex.: escritório de $p$.

4. Derivação: por extensão de sentido.

peça de propaganda; anúncio

Ex.: gosto muito dessa $p$.

publicidade

substantivo feminino 
1. característica do que é público

2. Rubrica: publicidade.

arte, ciência e técnica de tornar (algo ou alguém) conhecido nos seus melhores aspectos, para obter aceitação do público

3. Rubrica: publicidade.

divulgação de matéria jornalística, ger. por encomenda de uma empresa, pessoa, instituição etc., por qualquer veículo de comunicação

4. Rubrica: publicidade.

m.q. propaganda ('difusão')

Segundo o dicionário, propaganda é publicidade, publicidade é propaganda, termos sinônimos, portanto.

Sant'anna (1981, p. 81) emprega propaganda a partir da ideia de "implantar, de incutir uma idéia [sic], uma crença na mente alheia" e publicidade com o significado de divulgar, tornar público. Já Garcia (1982, p. 10-11) descreve propaganda "com o significado de propaganda ideológica, técnica de difusão de concepções gerais da realidade, com o objetivo de dirigir o comportamento dos indivíduos na sociedade. Distingue-se da publicidade destinada a induzir à compra de produtos ou utilização de serviços".

Sandmann (2012, p. 10) afirma que o termo "publicidade é usado para a venda de produtos ou serviços e propaganda tanto para a venda de produtos como no sentido de publicidade. Propaganda é, portanto, o termo mais abrangente e que pode ser usado em todos os sentidos".

Corroborando a escolha do termo propaganda, a revista Exame publicou no ano de 1977 um anúncio assinado pela Lage, Dammann \& Stabel Publicidade no qual ocorrem enunciados como:

Se a propaganda conseguiu vender um produto como este imagine o que pode fazer pelo seu. (Exame, jan. 1977, p. 50; grifo nosso) Anexo B, p. 195.

Propaganda: quem anuncia, anuncia para vender. (Exame, jan. 1977, p. 50; grifo nosso), p.195.

[...] não há nada que uma boa campanha de propaganda não venda. (Exame, jan. 1977, p. 50; grifo nosso), p. 195. 
Nos anos 1990, em outra revista do corpus, encontramos um anúncio assinado pela ABAP (Associação Brasileira de Agências de Propaganda, contendo os seguintes enunciados:

Aproveite para tomar um café puro enquanto você vê o que a propaganda está fazendo pelo café. (Veja, abr. 1992, p. 88-89; grifo nosso) Anexo B, p. 196.

Propaganda. Quem usa bem sabe o valor que tem. (Veja, abr. 1992, p. 88-89; grifo nosso), p. 196.

Como nosso intuito é o de estudar as características da linguagem da propaganda, mais especificamente a multimodalidade dos textos, não nos deteremos por mais tempo nessa polêmica e optaremos pelo termo propaganda, aproveitando o sentido mais abrangente sugerido por Sandmann (2012).

Outros autores ampliam os estudos sobre propaganda e publicidade e acrescentam que ambos se dividem em categorias: a propaganda pode ser ideológica, política, eleitoral, governamental, institucional, corporativa, legal, religiosa e social; a publicidade pode ser de produtos, de promoção, de serviços, cooperativa, comparativa e industrial (IASBECK, 2002).

Conforme Queiroz (2011), a propaganda pode ser oral, impressa, radiofônica, televisiva e na internet. Neste trabalho, em que analisaremos propagandas em revistas, interessa-nos, exclusivamente, as propagandas impressas.

\subsection{A linguagem da propaganda}

O papel da linguagem da propaganda (verbal e imagética) é persuadir, convencer e levar à ação pela palavra, portanto essa modalidade de linguagem precisa ser atrativa, motivadora. O grande desafio da linguagem da propaganda é fazer o consumidor parar e prestar atenção no texto, o que, muitas vezes, se dá pelo choque, pela provocação (SANDMANN, 2012). O texto deve provocar o estranhamento do consumidor, levando-o, 
assim, a se interessar pela leitura e, consequentemente, pelo produto, pelo serviço ou pela ideia propagada.

Carlos Drummond de Andrade (JORNAL DO BRASIL, 16 out. 1971) poeticamente comenta:

[...] Confesso que um dos meus prazeres é saborear os bons anúncios jornalísticos de coisas que não pretendo, não preciso ou não posso comprar, mas que atraem pela novidade de concepção, utilizando macetes psicológicos sutis e muito refinamento de arte. É admirável a criatividade presente nestas obras de consumo rápido, logo substituídas por outras. São anúncios que muitas vezes nos prestam serviços, pela imaginação ou pelo bom humor que contêm. E se nos vendem pelo menos um sorriso, ajudam a construir um dia saudável de trabalho.

A propaganda precisa prender a atenção do leitor e levá-lo à ação de consumir um produto ou serviço, ou ainda, a aderir a uma ideia, e isso deve acontecer de forma prazerosa, sedutora, atrativa.

As propagandas, como já mencionado anteriormente, podem ser classificadas pela sua natureza, de acordo com Muniz (2004), a partir da seguinte tipologia:

- Propaganda social - são as campanhas voltadas para as causas sociais, como desemprego, adoção de crianças, combate à desidratação, à aids, aos tóxicos, entre outras.

- Propaganda religiosa - tem por propósito divulgar a essência de uma igreja de comunicar a boa nova que vem de Deus, por meio de testemunho das pessoas ou da pregação de um religioso perante um grupo de pessoas.

- Propaganda legal - trata-se da propaganda que divulga, no Diário Oficial e em outros jornais, os balanços, atas de convocação e editais de empresas de capital aberto ou não. Promulgada pela Lei n. 6.404, de 1976.

- Propaganda corporativa - objetiva divulgar e informar sobre as políticas, funções e normas de uma companhia; de construir opinião favorável; e de criar uma imagem de confiabilidade acionária ou financeira da companhia.

- Propaganda institucional - tem por propósito preencher as necessidades legítimas da empresa, aquelas diferentes de vender um produto ou serviço.

- Propaganda governamental - tem por objetivo criar, reforçar ou modificar a imagem de determinado governo. 
- Propaganda eleitoral - objetiva conquistar votos para determinado candidato a cargo eletivo, valorizando ideias e indivíduos mediante processos delimitados.

- Propaganda política - tem como objetivo difundir ideologias políticas, programas e filosofias partidárias.

- Propaganda ideológica - responsável pela difusão de uma dada ideologia. Presta-se a orientar o comportamento social dos indivíduos.

A linguagem da propaganda carrega consigo visões de mundo de determinadas sociedades em espaços de tempo da história, caracterizando, assim, a relação entre linguagem de propaganda e ideologia.

\subsection{Propaganda e ideologia}

Ao carregar visões de mundo de sociedades e períodos da história, a propaganda veicula ideologias de épocas, de anunciantes, de grupos sociais. Essas ideologias podem ser marcadas nas propagandas somente como forma de sintonia e atualização dos anunciantes com os valores daquele período ou ainda como exercício e manutenção do poder de determinada classe dominante.

Segundo van Dijk (2015, p. 46):

[...] ao reconhecer o controle exercido sobre os mais fracos no domínio socioeconômico [...] um componente importante do exercício e da manutenção do poder é ideológico e baseia-se em vários tipos de aceitação, negociação, contestação e consenso.

Complementa ainda o autor (2015, p. 47) que "Torna-se crucial, desse modo, analisar o papel estratégico do discurso e de seus agentes (falantes, escritores, editores e assim por diante) na reprodução dessa forma de hegemonia sociocultural".

Os valores da sociedade transformam-se com o decorrer do tempo, como podemos observar em duas propagandas de cosméticos, uma da Helena Rubinstein e outra da Natura veiculadas na revista Claudia, uma nos anos 1980 e outra na contemporaneidade, em 2016: 
Hoje, transforme em realidade uma pele de aparência mais jovem. (Claudia, anos 1980) Anexo B, p. 197.

Estudar, transar, recomeçar, namorar, trabalhar, arriscar. Velho é julgar. Não existe idade certa para você fazer o que gosta. Faça parte dessa conversa. \#Velhapraisso. (Claudia, 2016) Anexo B, p. 198.

Nos valores da sociedade do século $X X$, a beleza, geralmente, estava condicionada à mulher jovem a quem o tempo não deveria transformar, a pele não deveria aparentar envelhecimento e, sim, jovialidade. No século XXI, os valores dessa mesma sociedade já tendem a destacar a mulher idosa competente para as mais diversas atividades e isenta de qualquer tipo de julgamento em função de sua maturidade/envelhecimento.

Além da beleza, outras muitas ideologias são evidenciadas nas propagandas das revistas, como requinte, classe, sucesso, elegância, status, alto padrão de vida, erotismo, origem estrangeira etc. Adjetivos (puro, nobre, privée), substantivos (elegância, modernidade, charme, conforto) aparecem com frequência nos textos de propagandas de revistas para enaltecer a ideologia ou visão de mundo de uma classe ou grupo social, como destacaremos no avançar de nossas análises.

\subsection{Propaganda: comunicação de massa}

A propaganda veiculada nas revistas configura uma forma de comunicação de massa e, assim, um fator importante nesse processo é a audiência. É a audiência que vai interpretar/compreender a ideologia da classe dominante evidenciada nas propagandas. Segundo Wolf (2009, p. 23), "a audiência compartilha em grande parte os pontos de vista próprios dos emissores, enquanto o mecanismo que essa formulação sugere é o de uma relação causal entre as opiniões do destinatário e seu comportamento fruitivo de comunicação de massa". 
O autor acrescenta ainda que "a interpretação transforma e modela o significado da mensagem recebida, preparando-a para as opiniões e para os valores do destinatário, às vezes a ponto de mudar radicalmente o sentido da própria mensagem" (2009, p. 24). A interpretação que a audiência processa pode gerar inúmeros sentidos que podem convergir com os do destinatário ou mesmo divergir dele.

A credibilidade do anunciante é outro fator relevante na comunicação estabelecida pela propaganda. Wolf (2009, p. 27) pontua que "os estudos experimentais sobre essa variável questionam se a reputação da fonte é um fator que influencia as mudanças de opinião que podem ser obtidas na audiência $e$, correlativamente, se a falta de credibilidade do emissor incide de modo negativo sobre a persuasão". Mais adiante, o autor afirma "que o problema da credibilidade da fonte não concerne à quantidade efetiva de informação recebida, mas à aceitação das indicações que acompanham essa informação" (2009, p. 28). Então podemos entender que a aceitação da comunicação estabelecida na propaganda está condicionada à credibilidade que a audiência deposita no anunciante. Outras vezes, ainda, a credibilidade da audiência está relacionada à celebridade (ator, cantor, jogador, médico, político) que divulga o produto pela propaganda daquele anunciante.

Quando trata do contexto social e dos efeitos dos meios da comunicação de massa, Wolf (2009, p. 37) afirma que:

os efeitos provocados pelos meios de comunicação de massa 'dependem das
forças sociais que prevalecem num determinado período' (LAZARSFELD, 1940,
p. 330): a teoria dos efeitos limitados desloca, portanto, o acento de um nexo
causal direto entre propaganda de massa e manipulação da audiência para um
processo mediato de influência, em que as dinâmicas sociais se cruzam com
processos de comunicação.

Podemos entender, portanto, que a propaganda impressa em revistas, como meio de comunicação de massa, tem como função relevante a persuasão do público leitor (consumidor) quanto à ideologia de uma época ou de uma classe e que a interpretação dessa comunicação está condicionada tanto à audiência quanto à credibilidade do anunciante e ao contexto social em que está inserida, o que demonstraremos em nossas análises. 


\subsection{A cena enunciativa no gênero propaganda de revista}

A partir do exposto anteriormente, levantamos um questionamento: Como analisar a construção da imagem das instituições financeiras nas propagandas de revistas impressas se nos textos de comunicação dessas propagandas há um intermediário que é o publicitário/agência de propaganda contratada? Entendemo-nos diante de uma questão que pode ser esclarecida a partir dos pressupostos da teoria da enunciação.

Para Maingueneau (2013), o que define a situação de enunciação linguística são: o enunciador, o coenunciador, o momento e o lugar da enunciação. Ele afirma que "todo enunciado implica um enunciador em relação ao qual é definido o 'você', constituído como tal pelo enunciador", acrescenta ainda que "se esse enunciador, suporte do ato de enunciação, coincide com o sujeito da frase, ele é representado sob a forma 'eu'; se coincide com o objeto direto, sob a forma 'me'; após a preposição aparece como 'mim' etc." (2013, p. 127) e conclui que "o 'eu' não é enunciador, mas apenas sua marca [...] e que 'você' não é coenunciador, mas, sim, um vestígio desse coenunciador, quando coincide com o sujeito da frase" (MAINGUENEAU, 2013, p. 127-128). Segue exemplo de enunciado retirado do corpus em que o coenunciador coincide com o sujeito da frase:

Aplicando em OR uma parte das economias que você faz, você se habilita aos mais fabulosos prêmios da história. E não arrisca um só centavo. (P1, Claudia, ago.1962), p.158.

No exemplo anterior, "você" denomina aquele que lê a propaganda exatamente no momento que está lendo, os verbos "faz", "arrisca" e "se habilita" demonstram a referência temporal e a espacial da situação de enunciação (aqui e agora). Para Maingueneau (2013, p. 128), "todo enunciado possui marcas de modalidade que indicam a atitude do enunciador em relação ao seu enunciado ou a seu coenunciador", ele acrescenta ainda que essas marcas de modalidade têm pesos modais diferentes: desde a simples apresentação de um fato estabelecido; passando pela atuação direta sobre o coenunciador por força da própria enunciação, ex.: "faça"; até a emissão de juízos de modalidade lógica "é possível que" ou de modalidade apreciativa "infelizmente". 
O autor (2013, p. 129) defende que o enunciador pode marcar sua presença a partir do que ele diz, direta ou indiretamente, e define que embreagem é "o conjunto das operações pelas quais um enunciado se ancora na sua situação de enunciação, e embreantes (também chamados de 'elementos dêiticos'), os elementos que no enunciado marcam essa embreagem"(grifos do autor). Como exemplos de embreantes ou dêiticos de pessoa, relaciona os pronomes pessoais eu, tu/você, nós, vós/vocês; os determinantes meu/teu, nosso/vosso, seu e suas flexões de gênero e número; e os pronomes o meu, o teu/o seu, o nosso, o vosso e suas flexões de gênero e número.

Maingueneau (2013) emprega o termo embreantes como dêiticos que, para Guimarães (1999, p. 9), "identificam-se como os elementos linguísticos que mais claramente mostram a presença do emissor no enunciado, o qual se realiza numa situação definida pelas coordenadas espaciais e temporais", ela assume ainda a definição de dêiticos como sinais que mostram/apontam e não que conceituam.

Retomando os embreantes de Maingueneau (2013), o autor exemplifica como temporais ontem, amanhã, hoje, há dois dias, dentro de um ano etc. e como espaciais aqui, lá e os grupos nominais compostos por este/esse ("esta casa", "essa mesa"), para determinar um objeto inanimado mostrado pelo enunciador (correspondente à terceira pessoa ou ainda não pessoa). Segundo o autor (2013, p. 131), "os embreantes distinguem-se dos outros tipos de signos linguísticos pela maneira como permitem ao coenunciador identificar seu referente" (2013, p. 131), os referentes podem remeter a três tipos de referências: baseadas na enunciação, baseadas no cotexto ou fora do contexto. O enunciado a seguir, extraído do corpus, exemplifica a referência baseada na enunciação:

Extrato descomplicado e extrato consolidado. A sua empresa, apoiada na simplicidade desses dois extratos, terá mais rapidez no seu dia-a-dia [sic] com o descomplicado e no fim do ano com o consolidado. (P9, Exame, maio 1982), p. 166.

O embreante "no fim do ano" marca a referência temporal ao ano vigente, ou seja, o momento da enunciação, o ano da publicação da propaganda naquela revista.

A teoria de Maingueneau também se dedica a dividir os planos de enunciação embreados, quando, além dos embreantes, apresenta outras marcas de presença do 
enunciador como: apreciações, interjeições, exclamações, ordens, interpelação do coenunciador. Esse plano é bastante comum nos textos em geral, como podemos perceber em outro exemplo retirado do corpus:

GOSTAMOS DE INVESTIDORES DESCONFIADOS. São os que mais facilmente compram nossas letras de câmbio. [...] Fale com o gerente de qualquer agência do Banco da Lavoura de Minas Gerais [...]. (P2, Veja e Leia, set. 1969) (grifo nosso), p. 159.

Nesse exemplo, o verbo "gostamos" e o pronome "nossas" remetem ao embreante nós - Banco da Lavoura, portanto, ao enunciador. O verbo no presente do indicativo "compram" remete ao embreante vocês, ou seja, o coenunciador. Além desses embreantes, observamos outras marcas da presença do enunciador, como sua apreciação quanto ao sentimento positivo em "gostamos" e quanto à característica dos investidores - "desconfiados". O enunciador apresenta sua apreciação implícita de que o coenunciador é desconfiado - exemplo de plano embreado. "Fale" é uma marca de interpelação do coenunciador, também ratifica o plano embreado.

O plano de enunciação não embreado é aquele em que ocorre a ausência de embreantes, ou seja, ocorre o apagamento do par "eu" e "você" assim como dêiticos de tempo e espaço, como se o enunciado estivesse isolado da situação de enunciação. No exemplo a seguir, observamos o apagamento do par "eu" e "você". As terminações verbais indicam que o evento ocorre no momento da enunciação, que situa os extratos como autônomos, como se existissem independentemente do enunciador e do coenunciador. Estes só aparecem de maneira indireta ao final do enunciado "Aproveite" (= você - coenunciador) e "do Banco Real" (= anunciante - enunciador), o que pode ser constatado no exemplo retirado do corpus: 
EXTRATO DESCOMPLICADO E EXTRATO CONSOLIDADO

O Extrato Real Descomplicado, além de fornecer os números dos cheques, data e valor, por ordem numérica, ainda apresenta a situação do Realmaster, o dinheiro que entrou e saiu, os valores bloqueados, aplicações em Open Market, empréstimos e vencimentos futuros. $\mathrm{O}$ Extrato Real Consolidado reúne o saldo da conta-corrente, os empréstimos feitos, os juros pagos. Aproveite estes serviços pioneiros do Banco Real. (P9, Exame, maio 1982), p.166.

Mangueneau (2013) mostra que, no discurso publicitário, que visa a provocar o coenunciador, podemos nos deparar com o apagamento do enunciador, do coenunciador e de outros embreantes, denominado duplo apagamento.

Há também, segundo a teoria do autor, um elemento on, do francês. Esse elemento "apresenta uma grande polivalência", pois, dependendo do contexto, "pode ser interpretado como referência ao enunciador, ao coenunciador, à dupla enunciador + coenunciador, à não pessoa, a um indivíduo, um grupo ou um conjunto indefinido (= as pessoas)" (MAINGUENEAU, 2013, p. 159), como o "quem" no exemplo a seguir, retirado do corpus. "Quem" pode ser qualquer pessoa, uma ou mais pessoas, ou seja, apresenta uma generalização. A seguir, exemplo retirado do corpus:

Quem compra Certificado de Depósito Bancário, Letras de Câmbio, Letras Imobiliárias e outros papéis tem que ser desconfiado. Quem é desconfiado gosta de prêto [sic] no branco. [...] (P2, Veja e Leia, set. 1969), p. 159.

Após essas discussões, passamos então ao ponto que responderá à questão inicial quando o teórico (2013, p. 166) afirma que "não se deve confundir o locutor com o produtor do enunciado" e esclarece que "o produtor é quem elaborou materialmente o enunciado" (o publicitário ou agência de propaganda) e "locutor é quem realiza a enunciação, é aquele a quem se referem 'eu', 'meu' etc. e que se encontra em um lugar que pode ser designado como 'aqui'” (o anunciante, nesta pesquisa, as instituições financeiras Banco da Lavoura/Banco Real/Santander). Assim, em nossas análises, consideramos como locutor: o anunciante (enunciador) - as instituições financeiras - que se dirige a/constitui um coenunciador - a quem denominamos leitor ou público-alvo. Quanto ao produtor caberá simplesmente a função de elaboração material dos 
enunciados. Nesse caso, ratifica Maingueneau (2013, p. 173) "[...] a criação de publicidades mobiliza um conjunto de pessoas trabalhando para as agências, as quais não aparecem: é a marca que, em relação ao público, se apresenta como responsável pela publicidade".

Maingueneau (2013) acrescenta que o locutor pode acumular diversificados papéis, ora como aquele que constrói a enunciação, ora como ponto de referência aos embreantes, ora como responsável pelos seus próprios pontos de vistas, ora como aquele que encena em sua fala as vozes daqueles a quem se dirige - a voz do "você", a voz de outro indivíduo ou grupo de indivíduos ( $3^{\text {a }}$ pessoa), a voz da coletividade ("sabese", "como se diz"). As incidências mais observadas no corpus são do locutor como ponto de referência aos embreantes e o locutor como responsável pelo seu próprio ponto de vista.

O autor admite que, às vezes, o locutor faz ouvir outras vozes e se situa em relação a elas, não se contentando em expressar somente as próprias opiniões. Tal posicionamento pode demonstrar neutralidade em relação ao que é dito, pode demonstrar estar de acordo com o ponto de vista, pode refutar, pode negar, pode marcar movimentos de concessão e de pressuposição, enfim, todos esses fenômenos Maingueneau (2013) denomina polifonia.

Além das questões relacionadas à cena enunciativa nesse gênero, é importante também observar que as propagandas não são compostas apenas de enunciados ou apenas de imagens, são textos e imagens e isso nos remete à necessidade de ampliar a discussão para a multimodalidade veiculada nas propagandas impressas, que apresentamos no decorrer do próximo capítulo. 


\section{A MULTIMODALIDADE NAS PROPAGANDAS EM REVISTAS IMPRESSAS}

O estudo da multimodalidade é um evento recente - as primeiras análises surgiram a partir da obra de Kress e van Leeuwen, em 1996. Textos multimodais são produzidos há muito tempo, mas não havia um olhar atento e dedicado a esse importante movimento da organização dos textos.

Segundo Rojo (s/d, p. 1):

As mudanças relativas aos meios de comunicação e à circulação da informação, o surgimento e ampliação contínuos de acesso às tecnologias digitais da comunicação e da informação provocaram a intensificação vertiginosa e a diversificação da circulação da informação nos meios de comunicação analógicos e digitais, que, por isso mesmo, distanciam-se hoje dos meios impressos, muito mais morosos e seletivos, implicando, segundo alguns autores, como Chartier e Beaudouin, mudanças significativas nas maneiras de ler, de produzir e de fazer circular textos nas sociedades.

A autora acrescenta ainda que:

já não basta mais a leitura do texto verbal escrito - é preciso colocá-lo em relação com um conjunto de signos de outras modalidades de linguagem (imagem estática, imagem em movimento, som, fala) [...]. Esses textos multissemióticos extrapolaram os limites dos ambientes digitais e invadiram, hoje, também os impressos (jornais, revistas, livros didáticos).

O mundo atual exige uma nova maneira de produzir textos que não se bastam mais somente pela escrita, hoje, mais do que palavras, necessitamos de imagens, cores, texturas, relevos e é isso que os textos multimodais nos proporcionam. E, se há uma nova maneira de produzir textos, há de se (re)criar uma nova maneira de ler esses textos.

Conforme Dionísio (2005, p. 161):

1. As ações sociais são fenômenos multimodais;

2. Gêneros textuais orais e escritos são multimodais;

3. O grau de informatividade visual dos gêneros textuais da escrita se processa num contínuo;

4. Há novas formas de interação entre o leitor e o texto, resultantes da estreita relação entre o discurso e as inovações tecnológicas.

Dionísio (2005, p. 161-162) afirma ainda que os textos escritos e orais são fenômenos multimodais, pois quando produzimos um texto (escrito ou falado), utilizamos mais de um modo de representação, ou seja, "palavras e gestos, palavras e entonações, palavras e imagens, palavras e tipográficas, palavras e sorrisos, palavras e animações". 
Seguindo essa linha, entendemos que o gênero propaganda impressa é um fenômeno multimodal, pois, nele, comumente encontramos, ao mesmo tempo, palavras e imagens, palavras e tipografias, palavras e charges, palavras e desenhos, palavras e ilustrações, palavras e mapas. A primeira página de um jornal também é um excelente exemplo de texto multimodal por veicular a pluralidade de linguagens que é recorrente nas propagandas impressas nas revistas.

\subsection{Leitura de textos multimodais}

$\mathrm{Na}$ tentativa de esquematizar o processo cognitivo desenvolvido na leitura dos textos que aliam a materialidade visual à escrita, Paes de Barros (2009, p. 166) descreve as seguintes estratégias de observação da multimodalidade:

1. Seleção e verificação das informações verbais - refere-se à ativação das capacidades de compreensão e apreciação da leitura dos textos verbais, como parte do processo de compreender a significação do texto como um todo.

2. Organização das informações da sintaxe visual - trata-se da observação dos elementos pictográficos de modo a selecionar e organizar as informações relevantes à construção da significação.

3. Integração das informações verbais e não verbais - trata-se da capacidade de observar e conjugar as informações da materialidade verbal à pictográfica, relacionando-as no ato de construção dos sentidos dos textos.

4. Percepção do todo unificado de sentido que se compõe através da integração dos materiais verbais e não verbais - trata-se da ativação de diversas capacidades linguístico-discursivas e de leitura aliadas à organização e observação das informações, através das quais o leitor constrói um todo de significação.

A autora sugere, portanto, que a multimodalidade nos textos exige mais que uma simples leitura. Demanda seleção, organização, integração e percepção das informações verbais e da sintaxe visual - materialidade visual e escrita. Para ler, adequadamente, um texto multimodal, mobilizam-se processos cognitivos complexos e realiza-se uma leitura inferencial, que gera a construção de significados ou, mais especificamente, no caso das propagandas de revistas, a produção de sentidos para o leitor.

O público leitor das revistas encontra nas propagandas impressas uma multiplicidade de textos verbais e recursos visuais. A leitura proficiente das tendências 
da multimodalidade é a nova competência necessária ao público leitor das propagandas em revistas no século $X X I$.

\subsection{As categorias das estruturas visuais de Kress e van Leeuwen}

Conforme Kress e Van Leeuwen (2006, p. 47), "Estruturas visuais não reproduzem simplesmente estruturas da realidade. Pelo contrário, elas produzem imagens da realidade que estão relacionadas com os interesses de instituições sociais [...]. Elas são ideológicas"2.

Alguns analistas já se dedicaram à tradução e descrição da importante obra Reading images: the grammar of visual design, dos autores Gunther Kress e Theo van Leeuwen. Encontramos em Nascimento, Bezerra e Heberle (2011), Bonifácio (2011) e Carmo (2016) uma leitura bastante sistematizada das categorias propostas pelos autores europeus, portanto faremos uso desses estudos, apesar de recorrermos, com frequência, ao texto original de Kress e van Leeuwen (2006).

As categorias das estruturas da gramática do design visual (GDV) de Kress e van Leeuwen (1996 [2006]) relacionam-se com as metafunções da linguística sistêmicofuncional (LSF) propostas e desenvolvidas por Halliday e Matthiessen (1978, 1985 [1994] e 2004 [2014]), como detalharemos no decorrer deste subitem.

Este trabalho não objetiva o estudo aprofundado da LSF, mas entendemos ser necessário apresentar uma síntese das metafunções para compreender melhor as relações que mencionamos anteriormente. De acordo com Martin e White (2005, p. 7):

Em seu cerne, LSF é um modelo multi-perspectivo [sic], projetado para prover os analistas de visões complementares para a interpretação da língua em uso. Uma das mais básicas complementariedades é a noção de tipos de significado - a ideia de que a língua é um recurso para mapear significados ideacional, interpessoal e textual uns nos outros em praticamente qualquer ato de comunicação. ${ }^{3}$

\footnotetext{
2 "Visual structures do not simply reproduce the structures of 'reality'. On the contrary, they produce images of reality which are bound up with the interests of the social institutions [...]. They are ideological." [N.A.: Tradução livre]

3 "At heart SFL is a multi-perspectival model, designed to provide analysts with complementary lenses for interpreting language in use. One of the most basic of these complementarities is the notion of kinds of
} 
A LSF, segundo Gouveia (2009, p. 14), "corresponde a uma teoria geral do funcionamento da linguagem humana, concebida a partir de uma abordagem descritiva baseada no uso linguístico". Ainda conforme o autor, pode ser concebida como um modelo de análise textual, pois fornece descrição, técnica e metalinguagem bastante úteis para a análise de textos, além de descrições que demonstram a variação da língua tanto entre grupos de falantes como entre contextos de usos diferentes.

Para Fuzer e Cabral (2014, p. 21), "na perspectiva sistêmico-funcional, a linguagem é um recurso para fazer e trocar significados, utilizada no meio social de modo que o indivíduo possa desempenhar papéis sociais". Os estudos de Halliday (2004, p. 23) remetem a pressupostos de que "a língua é um recurso para produzir significado, e o significado reside em padrões sistêmicos de escolhas"4. Para o autor, a linguagem desempenha três funções, além da função básica de comunicação, ela serve para a expressão de conteúdos, para estabelecimento e manutenção de relações sociais de uns com os outros e para estabelecimento de relação entre as partes de uma mesma instância de uso da fala. Ele nomeia essas funções como ideacional, interpessoal e textual.

As metafunções estão inter-relacionadas às variáveis do contexto situacional: ideacional/campo, textual/modo, interpessoal/relações. Essas categorias são descritas do seguinte modo:

O campo consiste em uma categoria contextual que concerne a um conjunto de sequências de atividades orientadas em relação a algum objetivo institucional global. [...]

O modo concerne à canalização da comunicação, ou seja, à textualização do fluxo informacional nos diversos meios semióticos, o que envolve, na contemporaneidade, as diversas tecnologias comunicativas [...]

As relações, por sua vez, envolvem o conjunto de relações sociais significativas entre participantes, tanto no que se refere a seus atributos permanentes quanto aos próprios papéis assumidos por eles em dada interação. (HALLIDAY, 1978 apud GONÇALVES SEGUNDO, 2011, p.151-152)

Para melhor entender de forma resumida a organização metafuncional da linguagem, apresentamos a seguir o quadro elaborado por Gonçalves Segundo (2014):

meaning - the idea that language is a resource for mapping ideational, interpersonal and textual meaning onto one another in virtually every act of communication." [N.A.: tradução livre]

4 "A language is a resource for making, and meaning resides in systemic patterns of choice". [N.A.: tradução livre] 


\begin{tabular}{|l|l|l|l|}
\hline Metafunção & Ideacional & Interpessoal & Textual \\
\hline $\begin{array}{l}\text { Parâmetro } \\
\text { contextual }\end{array}$ & $\begin{array}{l}\text { Campo: refere-se à } \\
\text { natureza da ação } \\
\text { social, ao conjunto } \\
\text { de atividades } \\
\text { orientadas em } \\
\text { geral, a objetivos } \\
\text { institucionais } \\
\text { globais. }\end{array}$ & $\begin{array}{l}\text { Relaçães: } \\
\text { concerne à } \\
\text { natureza da } \\
\text { relação social entre } \\
\text { os participantes da } \\
\text { interação em } \\
\text { termos de papéis } \\
\text { assumidos e de } \\
\text { diferença de poder. }\end{array}$ & $\begin{array}{l}\text { Modo: diz respeito à } \\
\text { canalização da comunicação, } \\
\text { ao suporte comunicativo e à } \\
\text { sua influência na construção } \\
\text { semiótica. }\end{array}$ \\
\hline Atividade & $\begin{array}{l}\text { Oração como } \\
\text { representação } \\
\text { (língua com } \\
\text { reflexão). }\end{array}$ & $\begin{array}{l}\text { Oração como } \\
\text { negociação (língua } \\
\text { como ação). }\end{array}$ & $\begin{array}{l}\text { Oração como mensagem } \\
\text { (criação da tessitura). }\end{array}$ \\
\hline $\begin{array}{l}\text { Principais } \\
\text { sistemas (HASAN, } \\
\text { 2009) }\end{array}$ & $\begin{array}{l}\text { Transitividade, } \\
\text { referência, } \\
\text { expansão, } \\
\text { projeção, tempo } \\
\text { secundário. }\end{array}$ & $\begin{array}{l}\text { Modo, modalidade, } \\
\text { tempo primário, } \\
\text { avaliatividade } \\
\text { envolvimento. }\end{array}$ & $\begin{array}{l}\text { Tema, informação, } \\
\text { foricidade, voz, conjunção. }\end{array}$ \\
\hline
\end{tabular}

Fonte: Gonçalves Segundo (2014, p. 1290)

Quadro 1 - Organização metafuncional da linguagem: contexto, atividade e sistema

Apesar das especificidades de cada uma das teorias - a LSF com a linguagem verbal e a GDV com a linguagem visual, podemos observar semelhanças entre a metafunção ideacional e a função de representação; entre a metafunção interpessoal e a função de interação; entre a metafunção textual e a função de composição.

Carmo (2016) não se propõe a pormenorizar as metafunções da LSF, mas contribui com uma síntese bastante relevante sobre as três categorias, permitindo-nos construir um paralelo entre aquelas e as da GDV, que esmiuçaremos posteriormente. Segundo a autora (2016, p. 92), "ideacional, para a transferência de experiências e visões de mundo", correspondendo ao retrato de participantes vivendo experiências e apresentando suas visões de mundo nos processos de ação, reação, mentais e verbais, da função representacional; Carmo (2016, p. 92) descreve também a vivência "interpessoal para permitir a interação e compreensão da dimensão produzida na esfera da alteridade", o que corresponde à função interacional que pode ser observada nas imagens de participantes em relação de contato, de distância social, de atitude e de modalidades naturalista ou sensorial. Prossegue ainda a autora, "textual para se compreenderem as formas de organização da linguagem como mensagem inteligível e coesa" (2016, p. 92), que podemos relacionar ao modo como os textos multimodais 
(imagéticos ou verbais) são organizados no espaço da página multimodal ou propaganda analisada.

Nas palavras de Carmo (2016, p. 92), as relações elaboradas no parágrafo anterior são concluídas da seguinte forma:

os significados representacionais, que descreveriam os participantes em ação; os significados interativos, que descreveriam a interação social construída por meio da imagem; e os significados composicionais, para buscar apreender de que forma os elementos que constituem a imagem são combinados e ajustados a uma proposição coesa e coerente.

Acrescenta ainda a autora que "essa descrição, por sua vez, está fundamentada na percepção de que existem semelhanças com as metafunções, mas que, no domínio do visual, elas se manifestam de outra forma".

Segundo Carmo (2016, p. 92) ${ }^{5}$ : "Tal qual na GSF quanto às escolhas feitas no sistema linguístico, em GDV, a inclusão ou exclusão de imagens ou de determinados detalhes está diretamente relacionada a implicações ideológicas", ou seja, o que a LSF realiza a partir da linguagem verbal, a GDV realiza a partir de recursos imagéticos e ambas utilizam-se de argumentos visuais ou verbais para defender ideias e promover visões de mundo que representam ideologias de uma classe ou de um período da história, como observamos nas décadas contempladas por este estudo.

Passaremos a demonstrar, resumidamente, como entendemos as categorias da gramática do design visual, a partir da qual norteamos nossas análises.

\footnotetext{
${ }^{5}$ Carmo (2016, p. 92) utiliza a terminologia GFS - gramática sistêmico-funcional.
} 


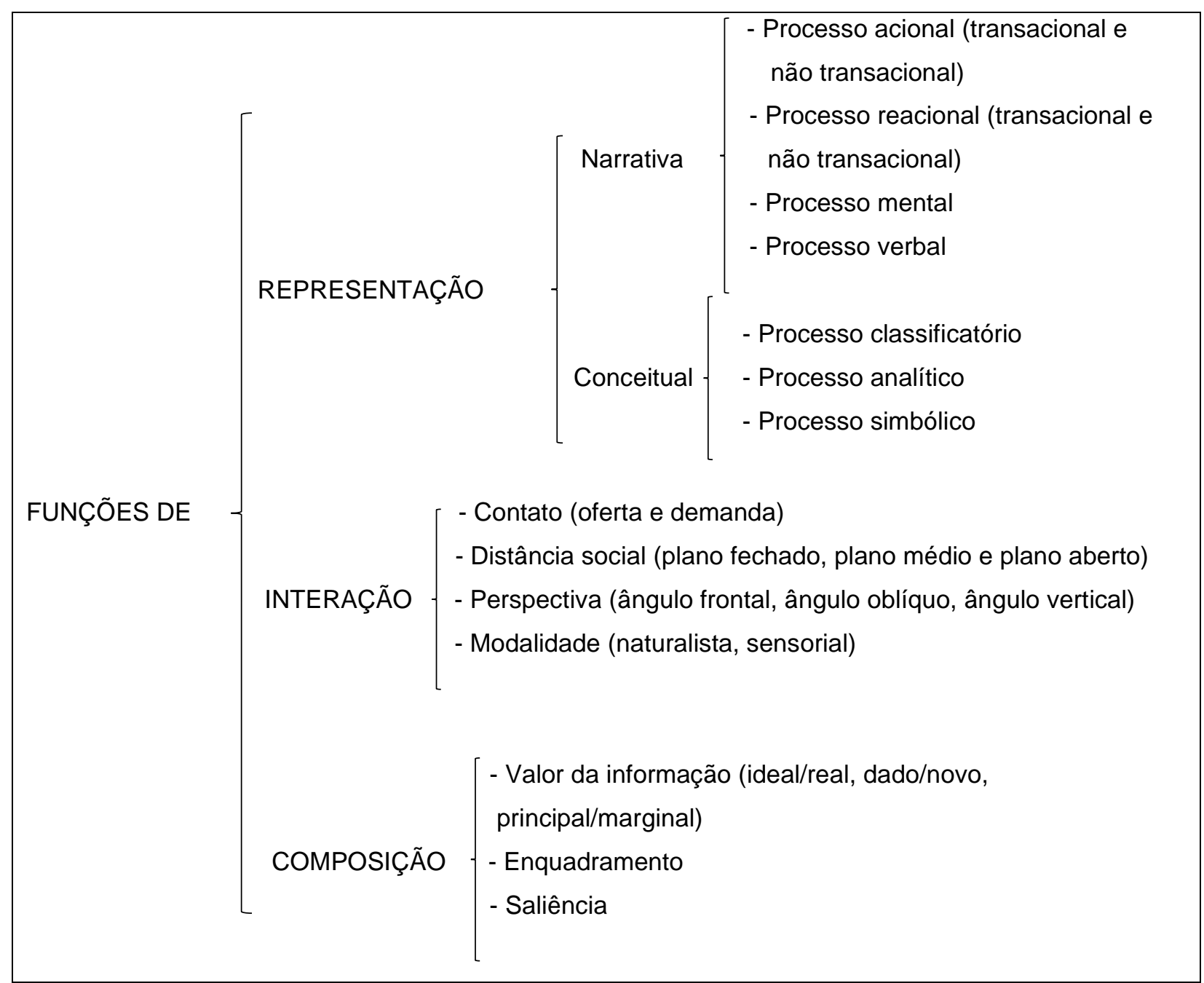

Adaptado de Carmo (2016, p. 93)

Quadro 2 - Visão das funções e categorias da gramática visual por Kress e van Leeuwen

As funções de representação, de interação e de composição serão descritas e exemplificadas nos itens desenvolvidos a seguir.

\subsubsection{Conceituação da função de representação}

Quanto à representação das imagens, Kress e van Leeuwen (2006) consideram as funções narrativas e conceituais. As narrativas "retratam participantes realizando ações sobre outros participantes ou envolvidos em acontecimentos" (NASCIMENTO; 
BEZERRA; HEBERLE, 2011, p. 534), demandam a presença de participantes, vetores e circunstâncias de tempo e espaço em que o evento se desenvolve.

As representações narrativas podem ser divididas em quatro tipos:

- Processos de ação - podem ser subdivididos em transacionais e não transacionais. Os processos de ação transacionais envolvem dois participantes e um vetor, os processos de ação não transacionais envolvem somente um participante e um vetor, como podemos diferenciar nas imagens abaixo:

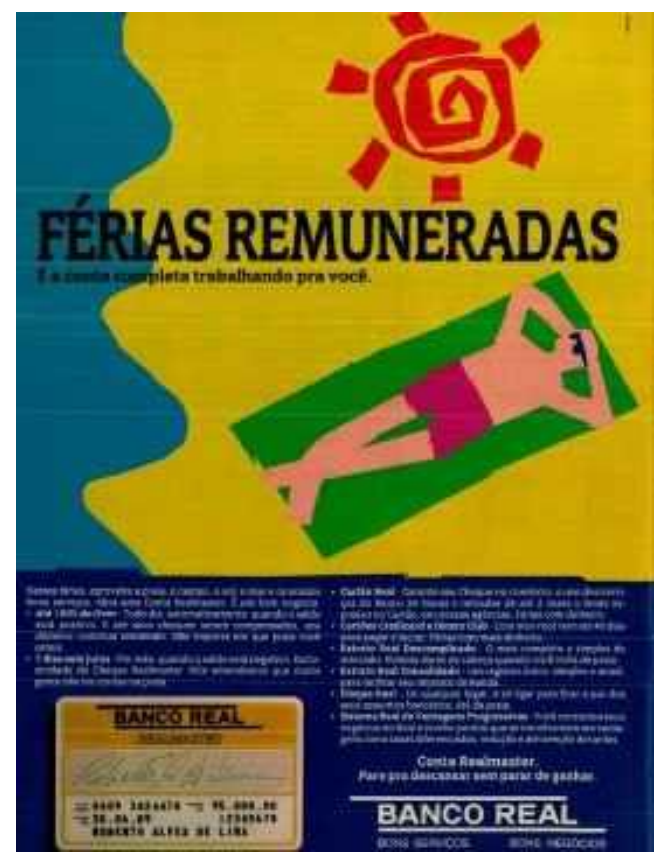

Figura 1 - Processo de ação não transacional (Veja, jan. 1989), p. 176.

Participante deitado na esteira exposto ao sol ação não é direcionada a nada - ou a ninguém.

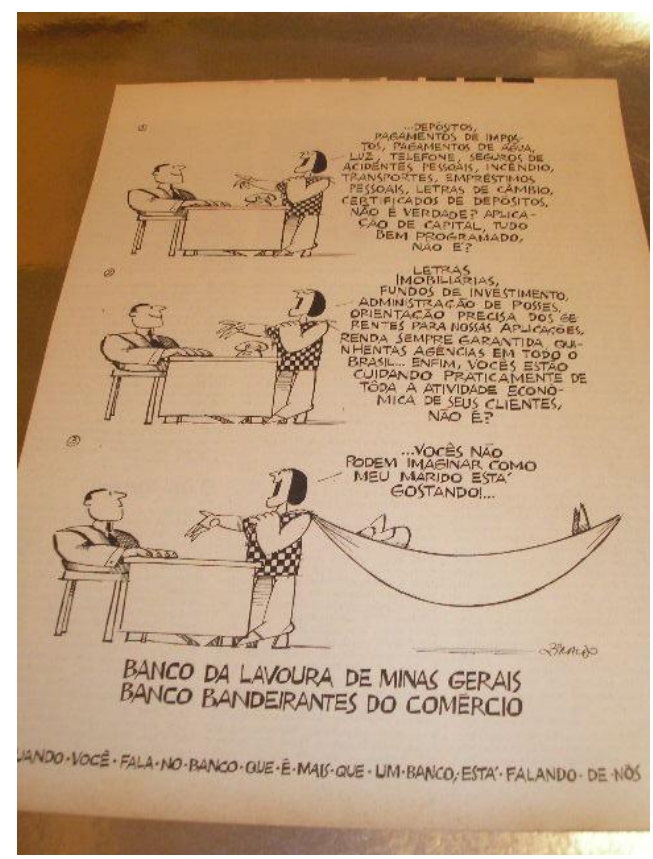

Figura 2 - Processo de ação transacional (www.propagandasemrevistas.com.br), p. 177.

Dois participantes, um falando e apontando para o outro com a mão. (vetor)

- Processos de reação - também podem ser transacionais e/ou não transacionais. Os processos de reação caracterizam-se por um vetor que é sempre o foco do olhar do participante. Quando identificamos o alvo do olhar, o processo é transacional, quando não identificamos o alvo, é não transacional, como podemos observar nas imagens a seguir: 


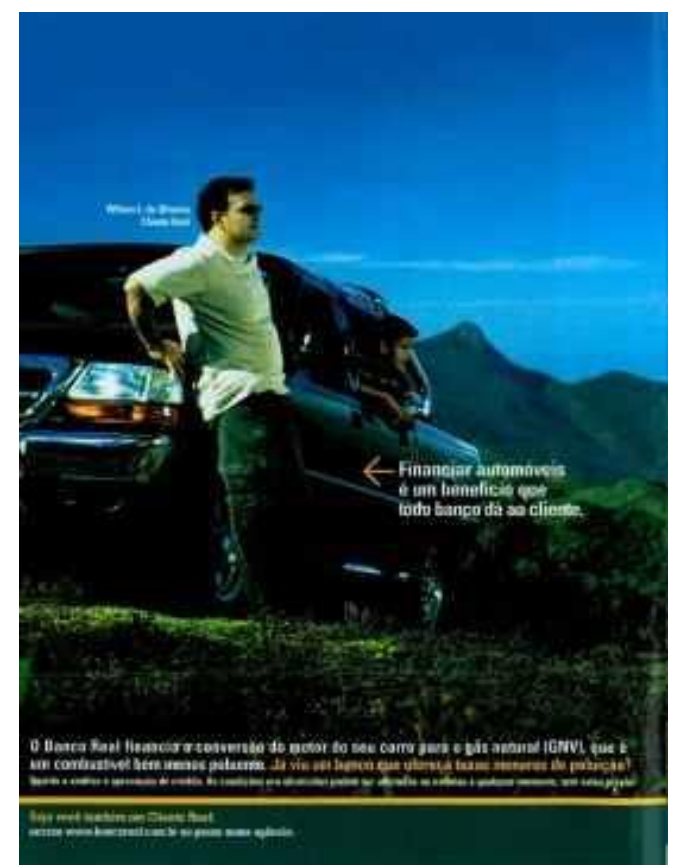

Figura 3 - Processo de reação não transacional (Veja, dez. 2003), p. 178.

Participante olhando para algo não identificado.

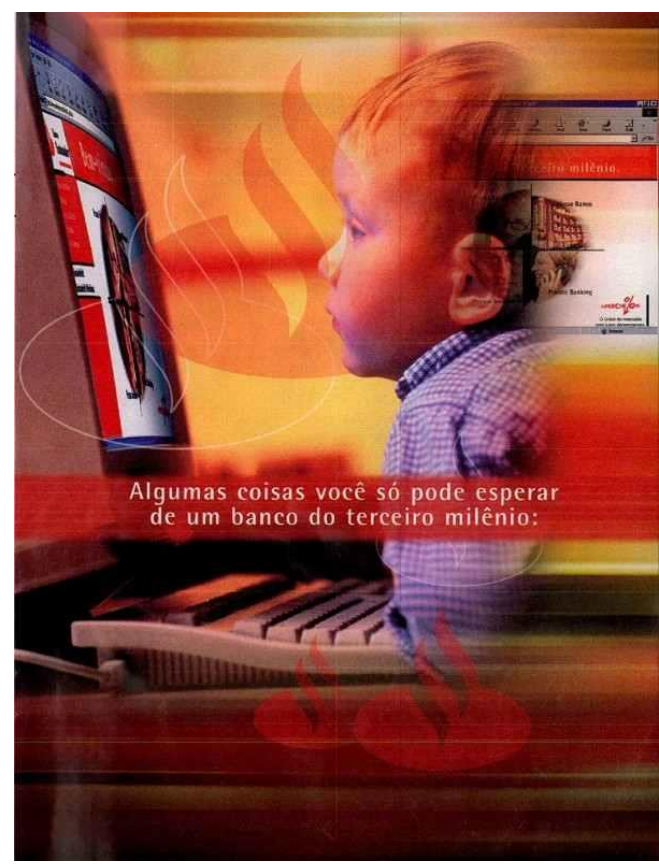

Figura 4 - Processo de reação transacional (Veja, já.2001), p. 179.

Participante olhando para a tela do computador, ou seja, o olhar direcionado à imagem na tela.

- Processos mentais - são identificados na imagem a seguir pelo balão de pensamento, indicando o que o participante está pensando.

- Processos verbais - são identificados na imagem a seguir pelo balão de fala, indicando o que o participante está falando.

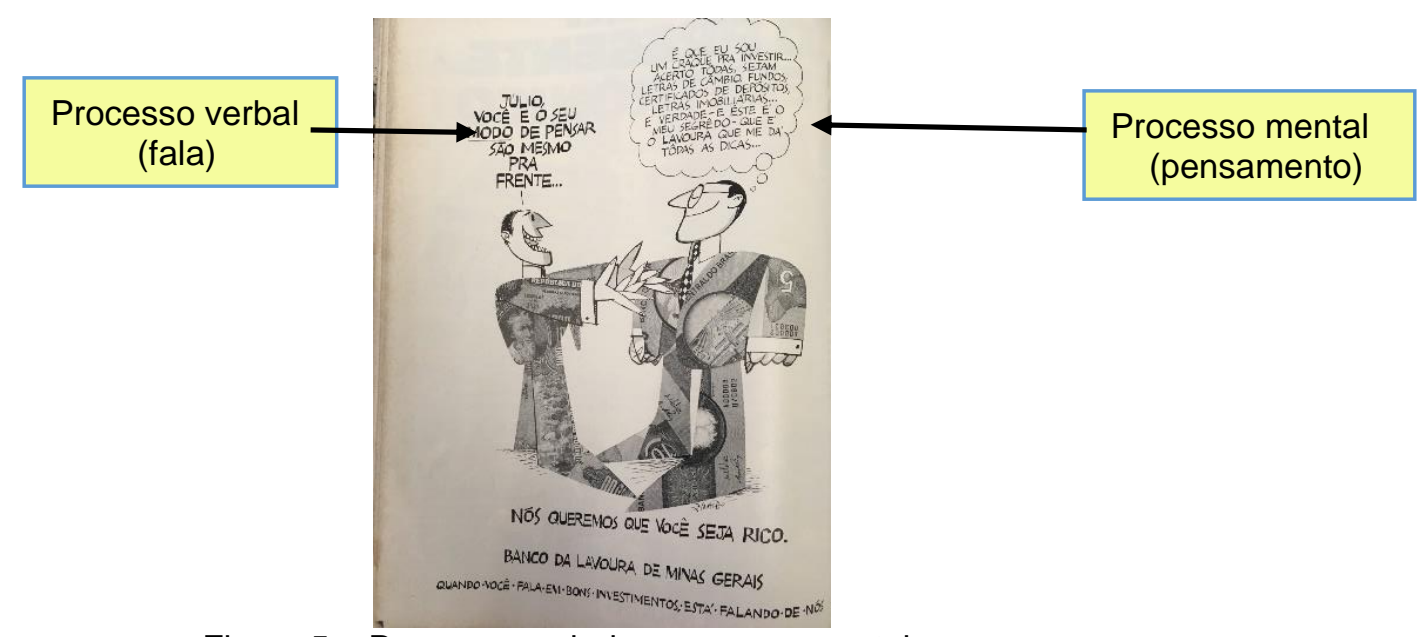

Figura 5 - Processo verbal e processo mental (Exame, dez. 1970, p. 41), p. 180. 
No mesmo exemplo, encontramos o processo verbal representado pelo balão de fala do personagem da esquerda (gerente) e o processo mental representado pelo balão de pensamento do personagem Júlio da direita (cliente).

As representações conceituais têm como foco os atributos e as identidades dos participantes e podem ser identificadas pela disposição dos participantes por agrupamentos e categorias, pela apresentação de participantes da parte pelo todo, pela ausência de vetores, pelo direcionamento do foco para os participantes, o que remete à ausência ou ao menor detalhamento do pano de fundo. As representações conceituais subdividem-se em três tipos:

- Processos classificatórios - são identificados pela categorização de participantes em determinada categoria, conjunto ou grupo. A classificação pode ser implícita ou explícita. É implícita quando não é acompanhada de legenda e é explícita quando é acompanhada de legenda que descreve os participantes.

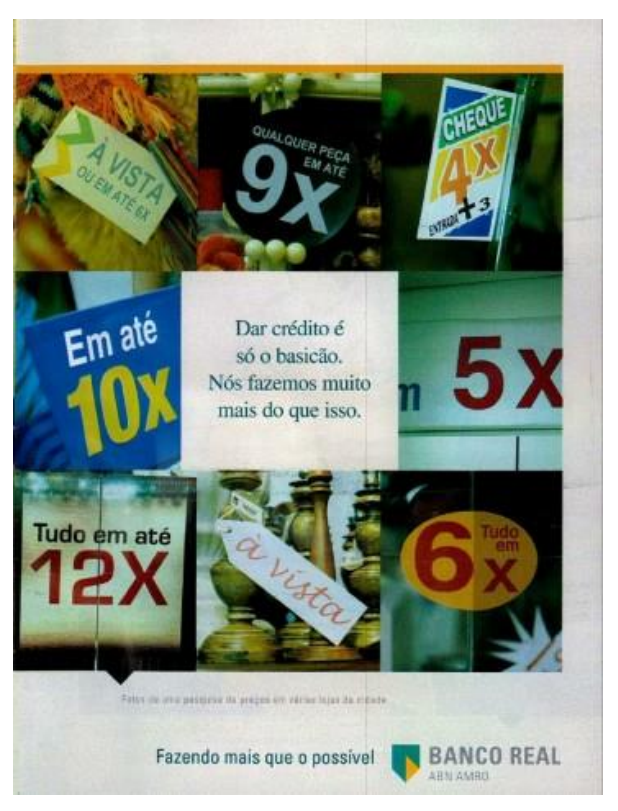

Figura 6 - Processo classificatório implícito (Veja, jun. 2006), p. 181.

Placas de quantidade de parcelas (não acompanhadas de legenda).

- Processos analíticos - são identificados quando a imagem traz uma representação da parte pelo todo. Exemplo: 


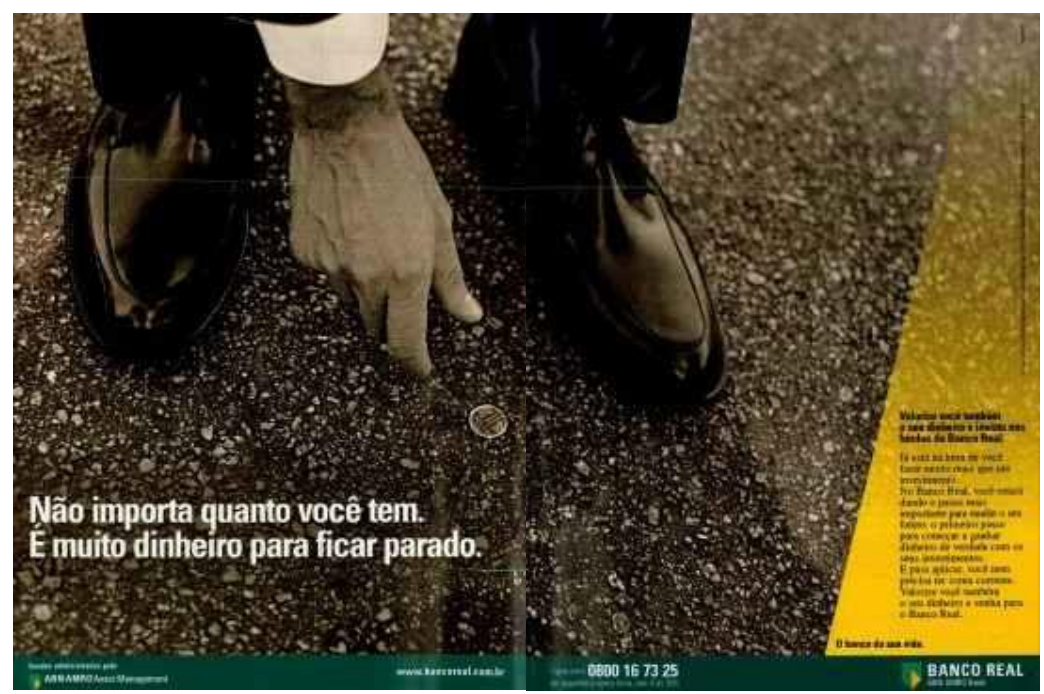

Figura 7 - Processo classificatório analítico (Veja, jun. 2001), p. 182.

A mão e os pés representando uma pessoa/cliente do banco.

- Processos simbólicos - identificados pela presença de elementos que simbolizam uma característica que não é intrínseca ao ser representado. Exemplo:

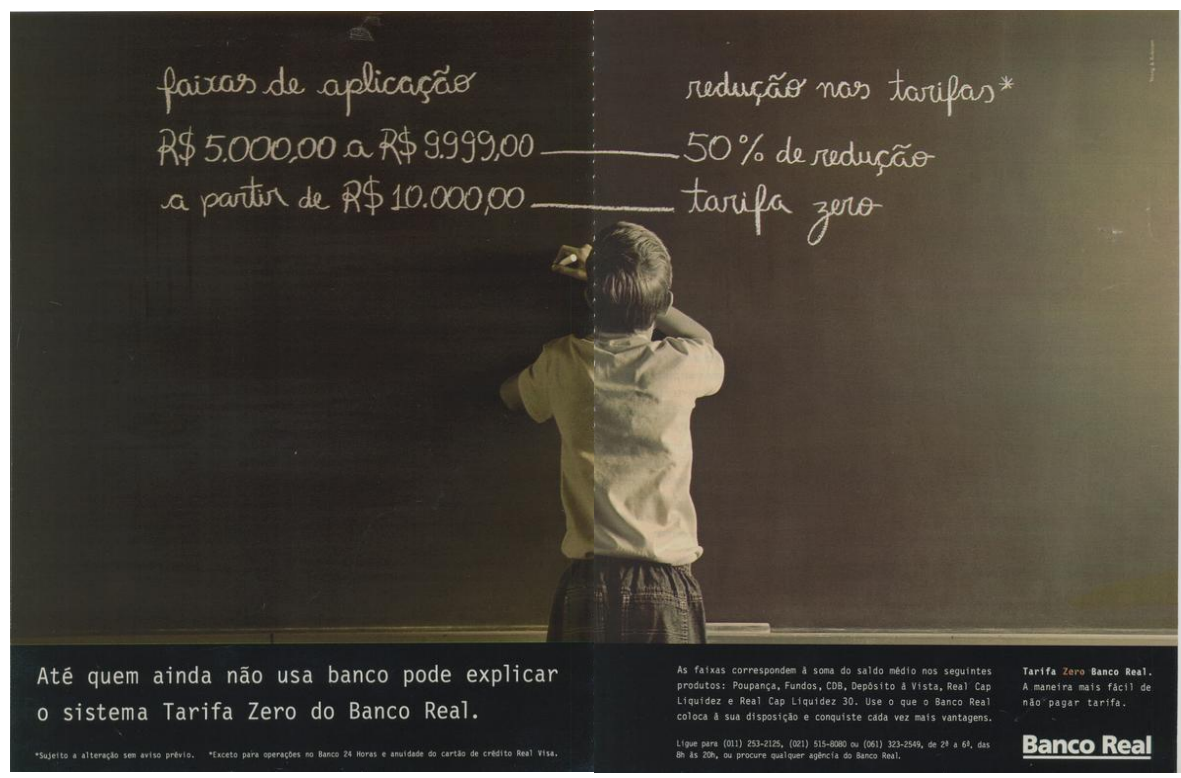

Figura 8 - Processo simbólico (Claudia, jul. 1997), p. 183.

Uma criança escrevendo cálculos matemáticos complexos como um professor. 


\subsubsection{Conceituação da função de interação}

Ao trabalhar com imagens, deparamo-nos com dois tipos de interação: a interação que ocorre entre os participantes daquela determinada imagem e a interação que ocorre entre os participantes da cena e quem lê a imagem, ou seja, o leitor. Essa relação pode ocorrer pelo contato, pela distância social, pela perspectiva ou ainda pela modalidade.

- Contato - ocorre a partir da linha do olhar do participante para com o leitor, de forma direta, denominada demanda (KRESS; VAN LEEUWEN, 2006) ou indireta, denominada oferta.

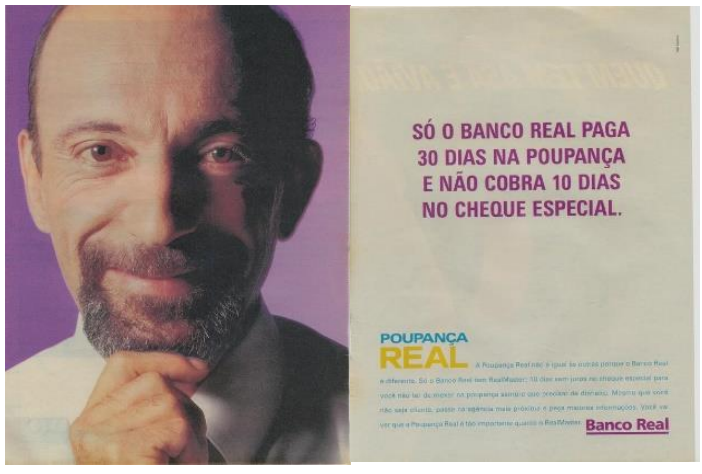

Figura 9 - Contato - demanda (Veja, out. 1996), p.184.

O participante olha diretamente para o leitor, relação pessoal.

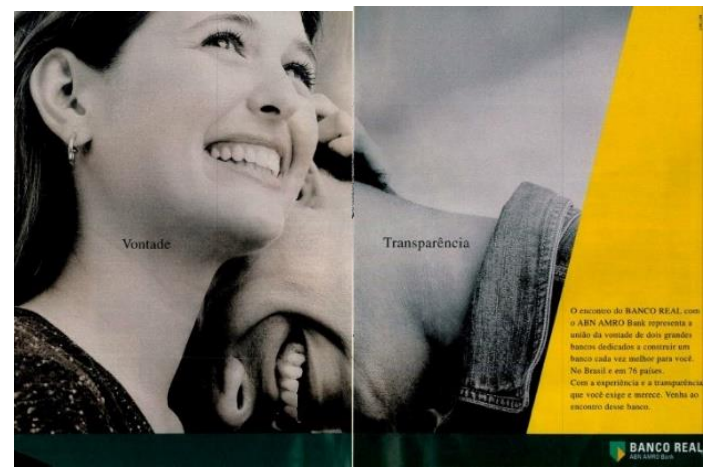

Figura 10 - Contato - oferta (Veja, mar. 2000), p. 185.

Os participantes parecem servir somente para a apreciação do leitor, não estabelecem contato direto do olhar, remetendo a uma relação impessoal.

- Distância social - essa função de interação está relacionada à proximidade ou ao distanciamento entre o participante e o leitor. O que determina isso é a distância ou proximidade do participante na imagem. Quanto mais distante (plano aberto long shot) mais impessoalidade, quanto mais próximo (plano fechado - close-up) mais intimidade. Kress e van Leeuwen também consideram o plano médio (medium shot) ou relação de nível social entre participante e leitor. 


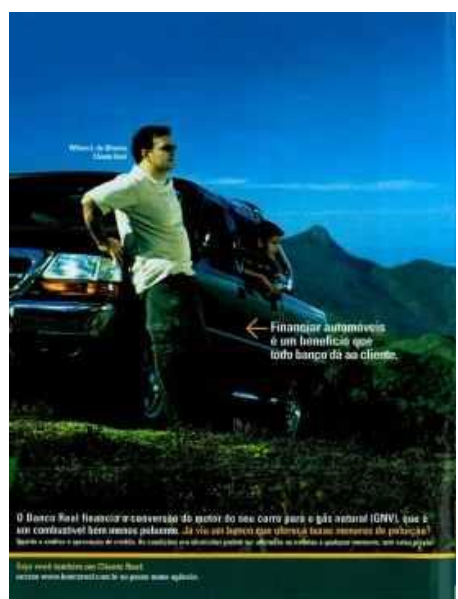

Figura 11 - Plano aberto long shot

Impessoalidade (Veja, dez. 2003), p.178.

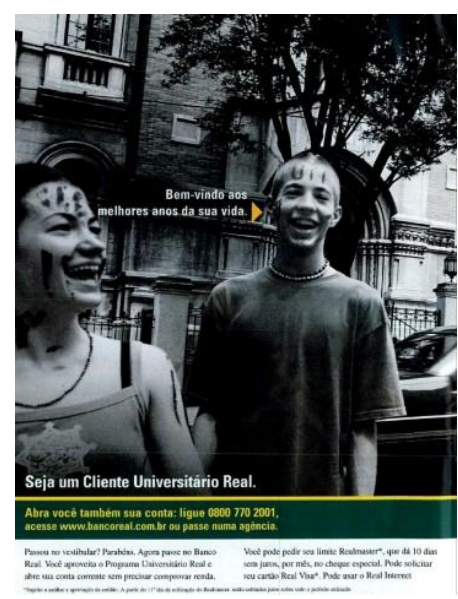

Figura 12 - Plano médio medium shot

Nível social (Veja, mar. 2002), p. 186.

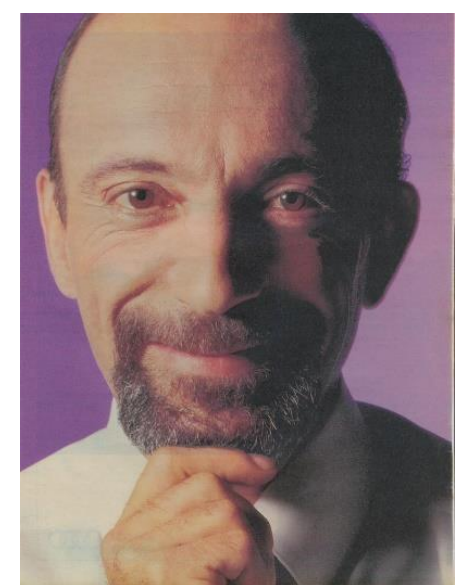

Figura 13 - Plano fechado close-up

Intimidade (Veja, out. 1996), p.184.

- Perspectiva/atitude - o ângulo sob o qual o participante é captado na imagem também remete à proximidade ou ao distanciamento entre ele o leitor. $\mathrm{O}$ participante pode ser captado de frente (mais íntimo), de lado (médio distanciamento) e de costas (distanciamento total - impessoalidade).

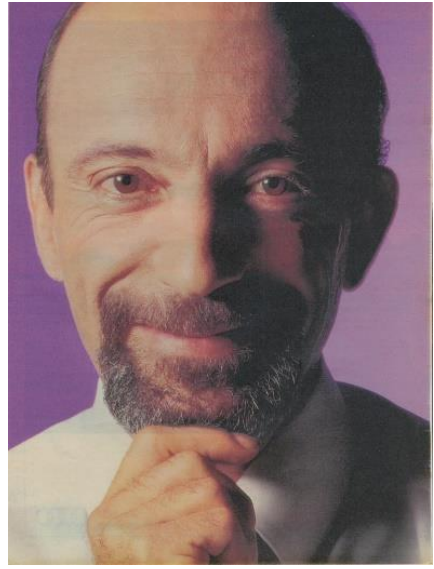

Figura 14 - Ângulo frontal - relação de proximidade (Veja, out. 1996), p. 184.

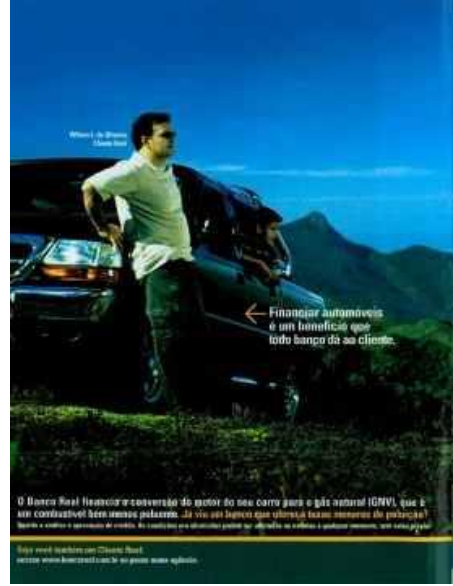

Figura 15 - Ângulo oblíquo - médio distanciamento (Veja, dez. 2003), p.178.

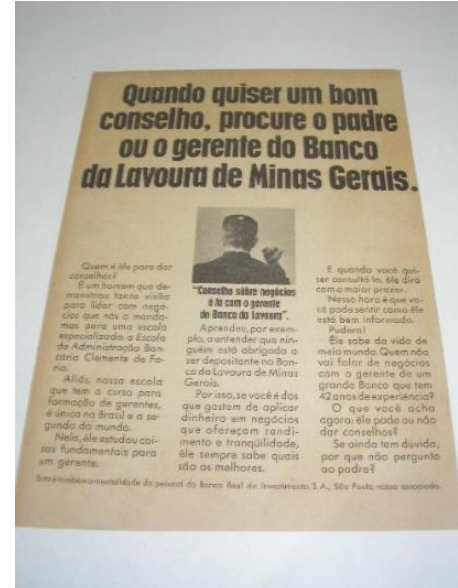

Figura 16 - Ângulo costas distanciamento total (www.propagandaemrevista.com), p.187.

Ainda no plano da perspectiva, o participante pode ser captado por um ângulo superior, por um ângulo de igualdade ou por um ângulo inferior, remetendo 
a um nível de poder do leitor: igualdade (como na propaganda da Veja, out. 1996, acima), mais poder ou menos poder, como exemplificado nas imagens a seguir.

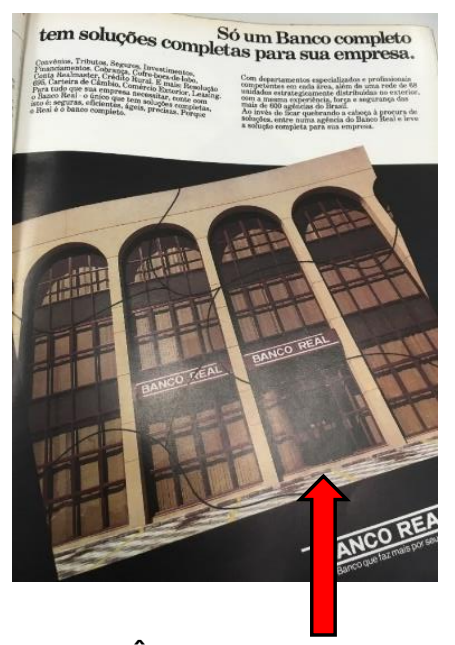

Figura 17 - Ângulo inferior (Exame, ago. 1985), p. 188.

O leitor observa a imagem de um ponto de vista inferior $=$ menor poder do leitor diante do enorme tamanho do prédio da agência bancária.

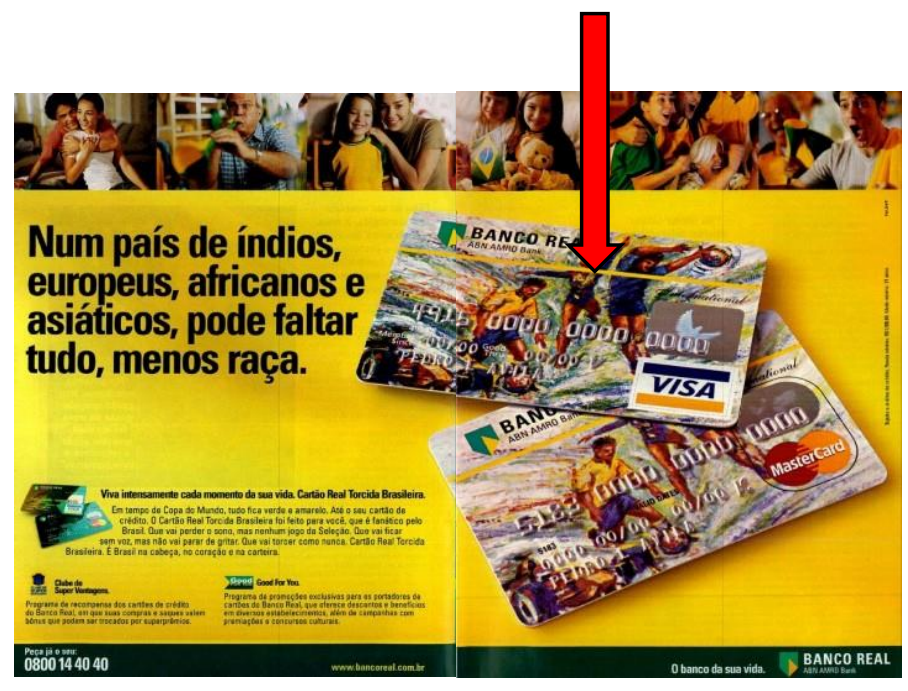

Figura 18 - Ângulo superior (Veja, jun. 2002), p. 189.

O leitor observa a imagem de um ponto de vista superior $=$ maior poder do leitor, diante das possibilidades que o cartão do banco pode lhe proporcionar.

- Modalidade - além do contato, da distância social e da perspectiva, a função interacional também pode ser expressa pela modalidade. Há duas categorias de modalidade: naturalista, quando a cena equivale à realidade, e sensorial, quando a imagem provoca um efeito que vai além da realidade, remetendo a emoções subjetivas, como podemos perceber nas duas imagens a seguir. 


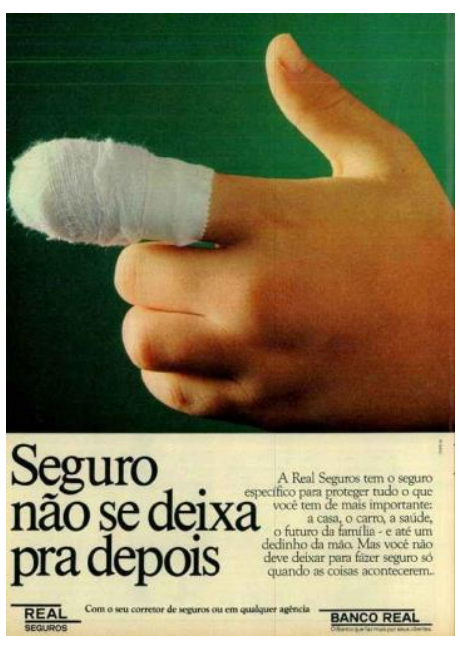

Figura 19 - Modalidade naturalista (Veja, dez. 1985), p. 190.

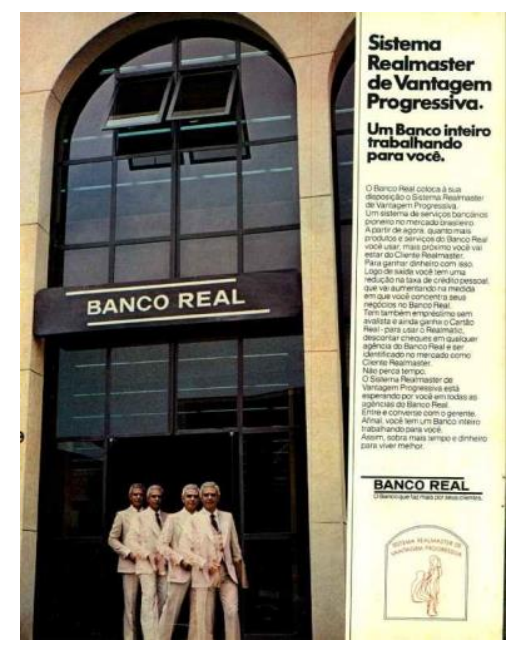

Figura 20 - Modalidade sensorial (Veja, jun. 1983), p. 191.

\subsubsection{Conceituação da função de composição}

A terceira e última função descrita por Kress e van Leeuwen (2006) é a composicional, que integra as funções de representação e de interação, relacionando-se ao modo como os textos multimodais são organizados no espaço da página das revistas em análise, por exemplo.

A função composicional subdivide-se em três aspectos: o valor da informação, enquadramento e saliência.

- Valor da informação - Kress e van Leeuwen (2006, p. 177) descrevem que "O posicionamento dos elementos [...] dota-os com valores informacionais específicos ligados às várias 'zonas' da imagem: esquerda e direita, acima e abaixo, centro e margem". 6

\footnotetext{
6 "The placement of elements [...] endows the with the specific informational values attached to the 'zones' of the image: left and right, top and bottom, centre and margin."
} 
A partir da descrição dos autores, podemos compreender que, em uma propaganda de página dupla, na página da esquerda, encontra-se o dado (conhecido) e, na página da direita, o novo. Exemplo:

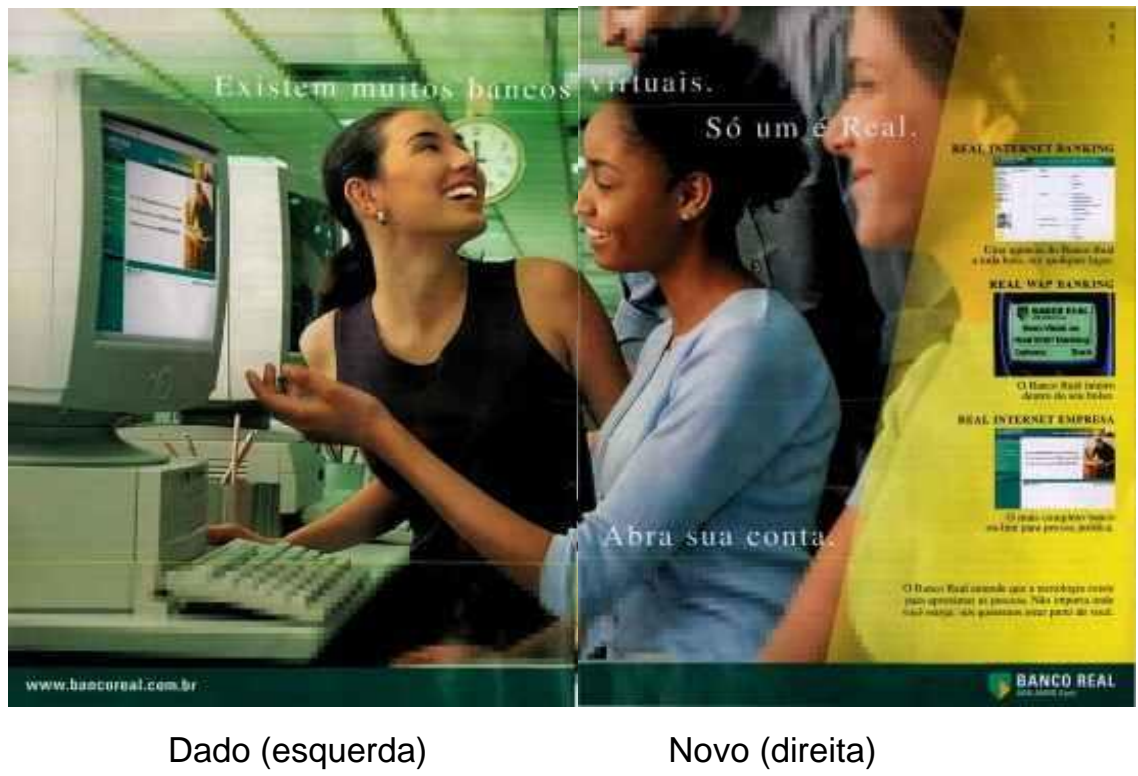

Figura 21 - Valor da informação - Dado × Novo (Veja, jan. 2001), p. 192.

Com relação às informações localizadas no topo (superior) ou na base (inferior) da propaganda, também se encontram valores diferentes. No topo, está o valor da informação ideal, enquanto na base está o valor da informação real. Exemplo: 


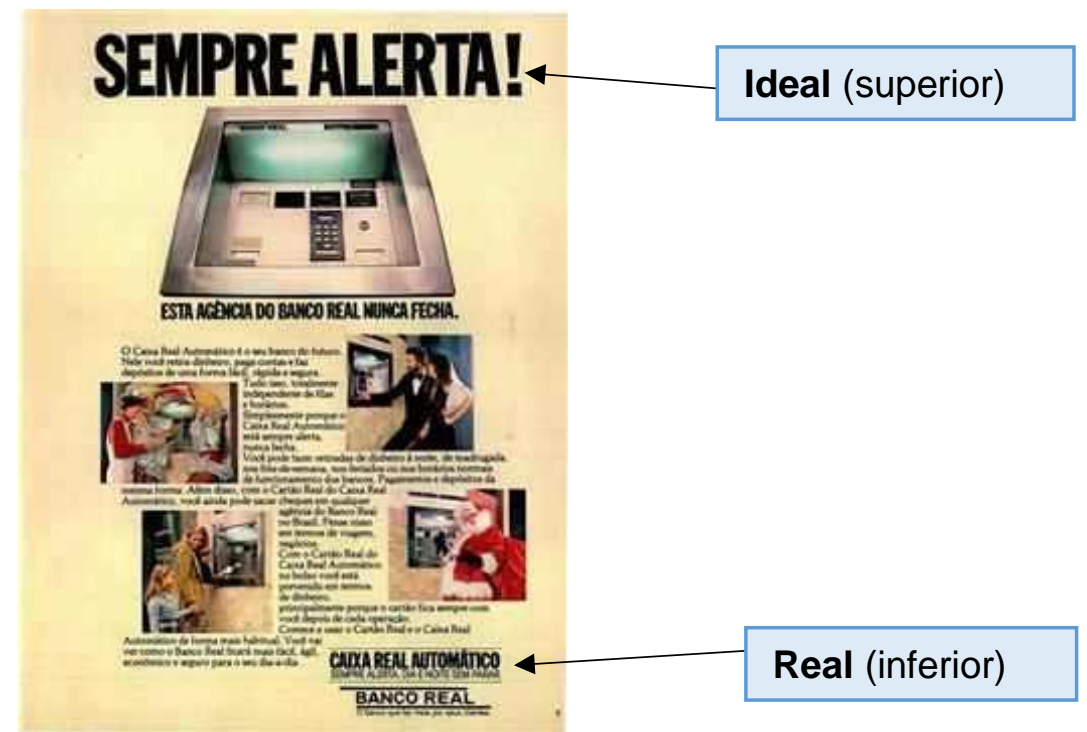

Figura 22 - Valor da informação Ideal $\times$ Real

(Veja, jun. 1982), p.193.

E ainda com relação ao centro e à margem da propaganda, podemos identificar o valor da informação principal e da marginal (complementar). Exemplo:

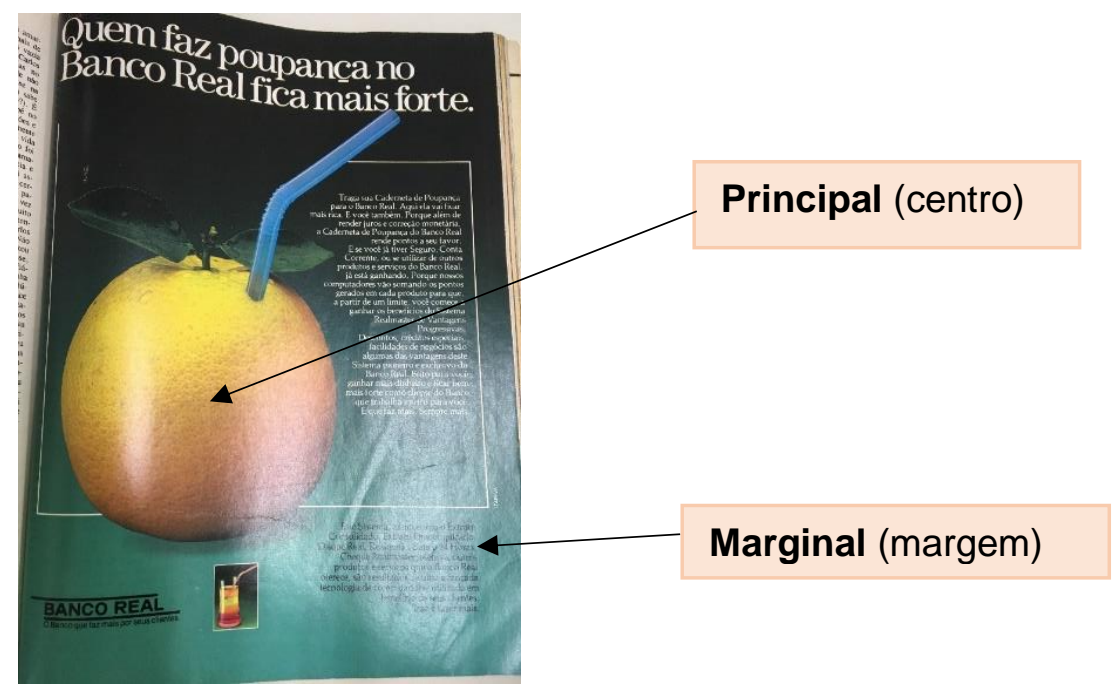

Figura 23 - Valor da informação Principal $\times$ Marginal (Claudia, out. 1984), p.194.

- Enquadramento - "A presença ou a ausência de dispositivos de enquadramento [...] desconecta ou conecta elementos de imagem, significando que eles estão ou 
não estão associados"7 (KRESS; VAN LEEUWEN, 2006, p. 177). Por exemplo, o singelo copo de suco com canudinho, fora da moldura que parece enquadrar a laranja.

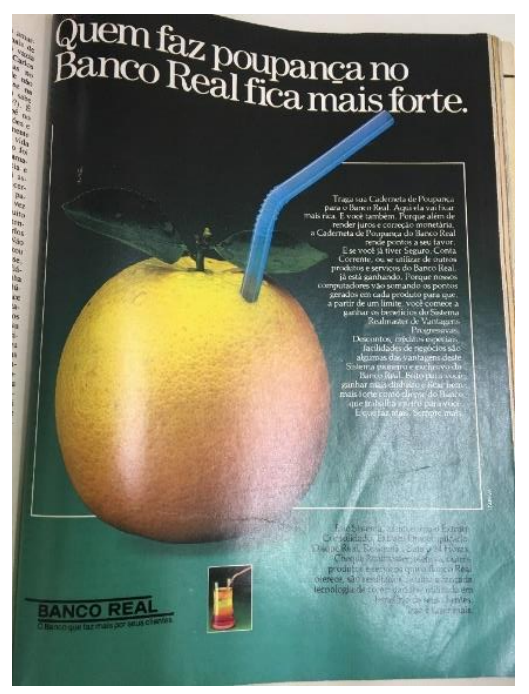

Figura 24 - Enquadramento/Saliência

(Claudia, out. 1984), p. 194.

- Saliência - segundo os autores, "os elementos [...] são dispostos para atrair a atenção do leitor em diferentes graus por meio de fatores como posicionamento em primeiro plano ou ao fundo, tamanho relativo, contrastes em valor tonal (ou cores), diferença em acuidade, etc." ${ }^{8}$ (2006, p. 177). Exemplo: o tamanho grande da laranja em relação à página.

Observa-se, a partir do exposto, que, na multimodalidade, as ilustrações, o texto verbal, as cores e o estilo tipográfico são intensivamente explorados nas propagandas impressas, veiculando significados e favorecendo a identificação do cliente com o produto anunciado ou, mais especificamente, com o anunciante (instituição financeira).

Dadas as especificidades das propagandas selecionadas e as características das modalidades da gramática visual, não realizamos as análises utilizando todas as categorias anteriormente descritas em todas as propagandas de todas as décadas, selecionamos para cada trio de propagandas aquelas categorias que comportam

\footnotetext{
7 "The presence or absence of framing devices [...] disconnects or connects elements of the image, signifying that they belong or do not belong together in some sense."

8 "The elements [...] are made to attract the viewer's attention to different degrees, as realized by such factors as placement in the foreground or background, relative size, contrasts in tonal value (or color), differences in sharpness, etc."
} 
subsídios significativos para o nosso propósito de análise. Entendemos também que assim evitaremos repetições e redundâncias.

No próximo capítulo, apresentamos as teorias sobre a construção de imagem e a argumentação no discurso defendidas por Amossy (2018) e sobre aspectos da identificação e atitude, a partir dos pressupostos de Martim \& White (2005). 


\section{A CONSTRUÇÃO DA IMAGEM NOS DISCURSOS DAS INSTITUIÇÕES FINANCEIRAS EM REVISTAS IMPRESSAS}

"Todo ato de tomar a palavra implica a construção de uma imagem de si" afirma Amossy (2018a, p. 9) na introdução da obra Imagens de si no discurso: a construção do ethos, texto que apresenta uma análise bastante completa e relevante sobre a construção da imagem nos discursos - desde a retórica clássica às teorias contemporâneas.

Segundo a autora, são as competências linguísticas e enciclopédicas, as crenças e o estilo que constroem a representação de alguém. O discurso efetua a apresentação do locutor, à revelia dos parceiros, nos mais diversos processos de interação humana. Amossy (2018a) alicerça suas convicções nos pressupostos de Aristóteles, Barthes e Mangueneau (1996) sobre a construção de uma imagem de si desde a antiga retórica. Envereda na linguística da enunciação, partindo de Benveniste até chegar a KerbratOrecchioni (1980), passando por Pêcheux (1969), "para quem A e B, nas duas pontas da cadeia de comunicação, fazem uma imagem um do outro" (AMOSSY, 2018a, p. 11) e, ainda, reciprocamente, uma imagem de si e do outro.

Ao apresentar as perspectivas interacionais, Amossy (2018a) menciona a importância dos trabalhos de Goffman (1973) voltados à produção de uma imagem de si nas interações e a influência desses trabalhos nos estudos da análise da conversação. Goffman (1974) introduz conceitos de representação, de papel e de face, resultando disso a ideia de que é possível criar uma boa imagem de uma profissão ou de uma religião a partir da construção de uma boa imagem de si mesmo.

Amossy (2018a) revela que o termo ethos tem sua primeira aparição nas ciências da linguagem a partir da semântica pragmática de Ducrot (1984), para quem o ethos está ligado ao locutor no discurso e, para conhecê-lo, é necessário analisar a aparência que Ihe é conferida nas modalidades de sua própria fala, portanto é a fala que influencia o outro.

Quanto à noção de ethos na análise do discurso de Mangueneau (1984), Amossy (2018, p. 16) afirma que "a maneira de dizer autoriza a construção de uma verdadeira imagem de si e, na medida em que o locutário se vê obrigado a depreendê-la a partir de 
diversos índices discursivos, ela contribui para o estabelecimento de uma inter-relação entre o locutor e seu parceiro", ou seja, a partir da eficácia da palavra, a imagem cria uma impressão positiva e suscita a adesão do outro.

O ethos nas teorias da argumentação contemporânea encontra uma atualização de suas noções. Perelman (1958 [1970]) inovou os estudos da retórica, mostrando o lugar central da arte de persuadir, reforçando "a necessidade que tem o orador de se adaptar a seu auditório, portanto, de fazer uma imagem dele e, correlativamente, de construir uma imagem confiável de sua própria pessoa, em função das crenças e valores que ele atribui àqueles que o ouvem" (AMOSSY, 2018a, p. 19). Conforme a autora, nos estudos subsequentes, destacam-se o panfletário, a narratologia e os estudos culturais, como novas perspectivas sobre o ethos.

A partir das discussões apresentadas, observamos que a construção da imagem nos discursos das propagandas de revistas analisadas decorre de argumentos de persuasão, e as instituições financeiras no papel de anunciantes buscam construir uma imagem positiva, sustentável, confiável e crível. O leitor é persuadido pelo discurso da propaganda quando se identifica com os valores daquele anunciante. Quando as instituições financeiras possuem as mesmas qualidades que o seu público-alvo tem ou deseja ter, provocam uma adesão muito mais efetiva dos leitores que compõem aquele público.

Apresentamos, a seguir, a imagem que o Banco Santander faz de si mesmo em seu site oficial e a imagem que outros fazem do banco em matérias de revistas e em redes sociais.

\subsection{A imagem que o (hoje) Banco Santander faz de si mesmo}

No website do hoje Banco Santander, a primeira frase que aparece, em letras destacadas, é "Somos hoje o terceiro maior banco privado do Sistema Financeiro Nacional". É assim, portanto, que a instituição financeira se vê e fala de si mesma. 
No mesmo website, o banco conta a própria história mencionando sua atuação no mercado brasileiro e sua estrutura, dividida entre banco comercial com atendimento de varejo, que abrange pessoas físicas e pequenas e médias empresas, e de atacado, que engloba grandes empresas e operações no mercado de capitais.

Relata atuar no mercado nacional desde 1982, com extensa rede de agências, postos de serviços e caixas eletrônicos e integrar o grupo espanhol Santander.

Descreve sua atuação no país da seguinte forma: "A operação do Brasil inspira sua atuação no propósito global 'Contribuir para que as pessoas e os negócios prosperem', de forma simples, pessoal e justa. Isso orienta a cultura, o processo de decisão e os comportamentos do Santander no Brasil e de suas empresas"9.

O Santander relaciona um cronograma de momentos importantes em sua história e nele constam desde a abertura do escritório de representação, três grandes aquisições - Banco Geral do Comércio, Banco Meridional, Bozano Simonsen e Banespa, e, por fim, Banco Real. Além disso, destaca a abertura de capital, a unificação da marca Santander e a finalização do novo datacenter.

Ainda falando de si mesmo, o banco disponibiliza no website seu código de conduta ética, que inicia assim: "Uma organização só é capaz de gerar vínculos sustentáveis e de confiança com os diferentes públicos com quem se relaciona quando tem uma forte cultura e princípios de conduta ética que sejam não só conhecidos como também praticados por todos os que fazem parte dela".

Constata-se, portanto, que a instituição financeira Santander busca por vínculos sustentáveis e de confiabilidade com seus clientes e com outros públicos com os quais se relaciona.

Na sequência, mostramos a imagem que os outros fazem do Banco Santander em matéria assinada na revista Exame e comentários no Facebook, pois, segundo Amossy (2018a, p. 18), baseando-se na definição de Quintiliano, "o argumento exposto pela vida de um homem tem mais peso que suas palavras" e é a partir da vida do Santander que o público constrói a imagem do banco.

9 Disponível em: <www.santander.com.br/institucional-santander/santander-no-brasil>. Acesso em: 20 jun. 2019. 


\subsection{O que os outros dizem sobre o Banco Santander}

Em matéria da revista Exame, de 25 de julho de 2018, assinada por Mariana Fonseca, o Santander aparece como o Banco que lucrou $R \$ 5,9$ bi no primeiro semestre daquele ano e é descrito como a instituição financeira que mais se expôs e obteve resultados acima dos demais bancos. "O Santander se expôs mais do que a concorrência no mercado de crédito e a estratégia deu resultados acima da média do mercado - e estamos falando do já bilionário mundo dos bancos". O que confirma a posição do banco como terceiro maior no Sistema Financeiro Nacional.

A matéria traz diversos números positivos para o banco e sua relação com os clientes, menciona muitos produtos e serviços diferenciados a executivos, às mulheres, aos estudantes, informa a respeito da campanha de dez dias sem juros que está fazendo do Santander um banco atrativo e próximo das necessidades de seus clientes. A matéria é encerrada afirmando que "Dando ou vendendo crédito, o lucro do Santander no Brasil não para de crescer". Portanto, o banco possui uma imagem positiva, sustentável e crível para os seus clientes e outros públicos que pretende conquistar, como investidores e consumidores de produtos e serviços bancários.

À matéria acima, soma-se outra divulgada nos meios eletrônicos, em novembro de 2000, ocasião em que o Santander adquiriu o Banespa: "o Banco Santander arrematou hoje o Banespa e assumiu o terceiro lugar no ranking das instituições privadas do País" e ainda "O maior conglomerado financeiro espanhol foi decidido a ganhar no leilão"10. Tais declarações parecem confirmar o que afirma o próprio banco de si mesmo em seu site oficial, descrito no item anterior.

$\mathrm{Na}$ busca de isenção nos comentários, posto que as matérias anteriores podem ter sido pagas ou encomendadas pelo banco, recorremos também ao Facebook do Banco Santander e encontramos duas postagens de clientes e/ou funcionários, como esta: "Quebre o espelho do medo e acredite em você!! Recebi o maior prêmio do Banco Santander Brasil, onde os melhores de cada segmento são homenageados em uma noite de muitas emoções e reconhecimento" (Bruna Pires - 05/04/2018), e esta: "Prêmio certo

\footnotetext{
10 Disponível em: <https://www.terra.com.br/economia/2000/11/20/047.htm>. Acesso em: 20 jun. 2019.
} 
4 trimestre. Nós ganhamos. Melhores da rede. Banco Santander aqui é o lugar" (Ana Paula Rocha - 20/03/2017). Esses enunciados nos parecem ser de funcionários que foram premiados por atingir as metas internas. Além desses, encontramos outros dois comentários de clientes sobre divulgação de vagas para trabalhar no Banco.

Diante disso, podemos perceber que a instituição valoriza e reconhece seus colaboradores/clientes e é bem avaliada por eles e reconhecida como uma boa empresa para se trabalhar.

\subsection{A argumentação no discurso das instituições financeiras nas propagandas}

Favero e Koch (1998 [1983]), nos primeiros estudos sobre linguística textual distinguiam texto e discurso da seguinte forma: "o termo discurso parece ter significado mais amplo que texto, visto englobar tanto enunciados pertencentes a uma mesma formação discursiva como as suas condições de produção" (1998, p. 24). É neste sentido mais amplo e abrangente que analisaremos os discursos das instituições financeiras nos textos multimodais das propagandas selecionadas para esta pesquisa.

Em sua obra Argumentação e discurso, Amossy (2018b) questiona a extensão da argumentação no discurso. Menciona que a análise argumentativa transcorre em corpŏra que circulam desde a conversação, passando pelo discurso político, das mídias e da internet até o texto literário. Complementa que "há argumentação quando uma tomada de posição, um ponto de vista, um modo de perceber o mundo se expressa sobre um fundo de posições e visões antagônicas, ou tão somente divergentes, tentando prevalecer ou fazer-se aceitar" (AMOSSY, 2018b, p. 42). Entendemos, portanto, que a extensão da argumentação no discurso está condicionada a uma situação em que há, no mínimo, duas opções previstas.

Segundo a autora, a argumentação instaura-se a partir de aspectos variados, "permite dar conta da argumentatividade que atravessa o discurso, revestindo-se de aspectos que, às vezes, são muito diferentes" (p. 44). A dimensão argumentativa inerente 
a muitos discursos diferencia-se daquela que caracteriza alguns discursos apenas. A mera transmissão de um ponto de vista que não almeja mudar as posições do alocutário não deve ser confundida com a intenção de persuasão consciente subsidiada por estratégias pensadas para essa finalidade.

No tocante ao agrupamento dos gêneros, Amossy (2018b) menciona a publicidade ou propaganda, tema de nossas análises, como discursos com visada persuasiva. Encerra as considerações iniciais de sua obra definindo argumentação como "meios verbais que uma instância de locução utiliza para agir sobre seus alocutários, tentando fazê-los aderir a uma tese, modificar ou reforçar as representações e as opiniões que ela Ihes oferece, ou simplesmente orientar suas maneiras de ver, ou de suscitar um questionamento sobre um dado problema" (p. 47), ou seja, a argumentação, numa definição reformulada e ampliada de Perelman (1970), é multifacetada.

Em outro capítulo da mesma obra de Amossy (2018b), a autora trata da adaptação do discurso e, portanto, da argumentação, ao auditório e cita Perelman e OlbrechtsTyteca (1970, p. 21), que afirmam que "a argumentação visa a obter a adesão daqueles a quem se dirige, ela é, por inteiro, relativa ao auditório que procura influenciar". Aqui percebemos a importância do público-alvo - leitor de revistas e das propagandas nelas contidas - para a construção da imagem objetivada pelas instituições financeiras.

Se a relação entre orador e auditório se faz a partir da troca verbal, não só a imagem do orador é significativa, mas também a imagem que o orador constrói do auditório. As instituições financeiras devem saber a quem elas estão dirigindo o seu discurso, portanto, elas constroem uma imagem de seu público e constituem seu discurso para atingir/persuadir esse público-alvo.

Conforme Amossy (2018b, p. 54), “a necessidade de se adaptar ao auditório (a expressão é de Perelman) ou a importância concedida às opiniões do outro é uma condição sine qua non de eficácia discursiva". Complementa ainda a autora que a adesão do público-alvo ao discurso do orador é conquistada quando este se baseia em premissas já aprovadas por aquele, a partir, por exemplo, das evidências compartilhadas, ou seja, "o auditório é designado silenciosamente pelas crenças, opiniões, valores que o discurso Ihe atribui explícita ou implicitamente" (AMOSSY, 2018b, p. 62). Decorre daí a 
necessidade de o anunciante ter uma imagem precisa do público que pretende influenciar e compartilhar com ele valores, crenças, opiniões, visões de mundo e objetivos comuns.

Amossy (2018b, p. 172-173) afirma que "a análise argumentativa não examina o léxico em si e por si: ela se preocupa com a maneira pela qual a escolha dos termos orienta e modela a argumentação", acrescenta ainda que a seleção do léxico não é nem pode ser "desprovida de peso argumentativo", as escolhas lexicais, intencionais ou não "permitem uma exploração argumentativa".

Partindo dessas premissas, observamos que muitos são os recursos argumentativos que o anunciante pode selecionar para compartilhar evidências e persuadir o seu público-alvo como a seleção lexical, o implícito, os conectores, a analogia, o silogismo, as figuras, os modalizadores, as representações, as simbologias. Outro aspecto ponderável para as nossas análises está relacionado à identificação e atitude - aspectos da teoria da valoração (ou avaliatividade) - que apresentamos no próximo item.

\subsection{Valoração ou avaliatividade: a linguagem da avaliação}

Retomamos os pressupostos da LSF para tratar da teoria da valoração ou avaliatividade, posto que esta é uma abordagem que se presta a analisar a avaliação e a perspectiva em textos a partir de diferentes recursos linguísticos de aspecto semântico, ligados à metafunção interpessoal, o que corrobora a análise da construção de imagem à luz da multimodalidade nas propagandas de instituições financeiras.

Essa abordagem, segundo White (2004, p. 177):

está interessada nas funções sociais desses recursos, não simplesmente como formas através das quais falantes/escritores individuais expressam seus sentimentos e posições, mas como meios que permitem que os indivíduos adotem posições de valor determinadas socialmente, e assim se filiem, ou se distanciem, das comunidades de interesse associadas ao contexto comunicacional em questão. 
A partir dessa perspectiva, observamos que tal ferramenta oferece meios para evidenciar as relações estabelecidas entre os anunciantes e os leitores nos discursos das propagandas das revistas analisadas nesta tese.

A valoração ou avaliatividade constitui um dos principais sistemas inseridos na metafunção interpessoal - categoria contextual "relações" (que concerne à natureza da relação social entre os participantes da interação em termos de papéis assumidos e de diferença de poder), ou seja, em termos léxico-gramaticais, destaca-se como um dos três sistemas complementados pela negociação e o envolvimento. A valoração está diretamente interligada a Significados Identificacionais (individual e social/coletivo) assim como a Significados Acionais e a Representacionais (GONÇALVES SEGUNDO, 2011), sendo que, nesses últimos, a associação é menos intensificada.

Martin e White (2005) apresentam a valoração (ou avaliatividade) subdividida entre atitude, engajamento e gradação, como veremos a seguir.

\subsubsection{Atitude}

A atitude abrange três domínios semânticos: a emoção, o comportamento e a estética, que se subdividem nos valores de afeto, de julgamento e de apreciação. Martin e White (2005, p. 42-43) definem esses valores, resumidamente, da seguinte forma:

Afeto está relacionado ao registro de sentimentos positivos e negativos: nós nos sentimos felizes ou tristes, confiantes ou ansiosos, interessados ou entediados? $[\ldots]$

Julgamento diz respeito à atitude em relação a comportamento que admiramos ou criticamos, elogiamos ou condenamos. [...]

Apreciação envolve avaliações de fenômenos semióticos e naturais de acordo com o modo que eles são valorizados ou não em determinado campo. [... $]^{11}$

Por se tratar de sistemas semântico-discursivos, tanto o subsistema da Atitude como o próprio sistema da valoração (avaliatividade), possuem uma imensa gama de

\footnotetext{
11 "Affect is concerned with registering positive and negative feelings: do we feel happy or sad, confident or anxious, interested or bored? [...]" [N.A.: tradução livre]

"Judgement deals with attitudes towards behavior, which we admire or criticize, praise or condemn. [...]" "Appreciation involves evaluations of semiotic and natural phenomena, according to the ways in which they are valued or not in given field. [...]" [N.A.: tradução livre]
} 
possibilidades léxico-gramaticais, portanto, não são realizáveis por estruturas fixas. Martin e White (2005) apresentam uma hipótese que pode não se aplicar à totalidade das análises, mas constitui excelente recurso, inclusive, para as nossas análises, nesta tese.

- Afeto - "Envolve, por regra, um participante consciente, sobre o qual repousa a validade modal da atitude [...] abarca, usualmente, um fenômeno responsável pela ativação da emoção, denominado gatilho" (GONÇAVES SEGUNDO, 2011, p. 171). Marca o sentimento no discurso, pode representar uma qualidade, pode ter sentido positivo ou negativo e pode ser expresso por diversas categorias léxicogramaticais, como epítetos, atributos, advérbios, substantivos, verbos e adjuntos, conforme exemplo a seguir, extraído do corpus.

As pessoas que voltaram a visitar o Jardim Botânico voltaram a ter aquele ar de felicidade ao passear por suas aléias [sic] e bosques. (P11, Veja, jun. 1992), p.168.

White (2004), baseado em estudos anteriores de Martin (1997 e 2000), mostra que a valoração ainda subclassifica o afeto a partir de seis fatores, como indicado a seguir. 


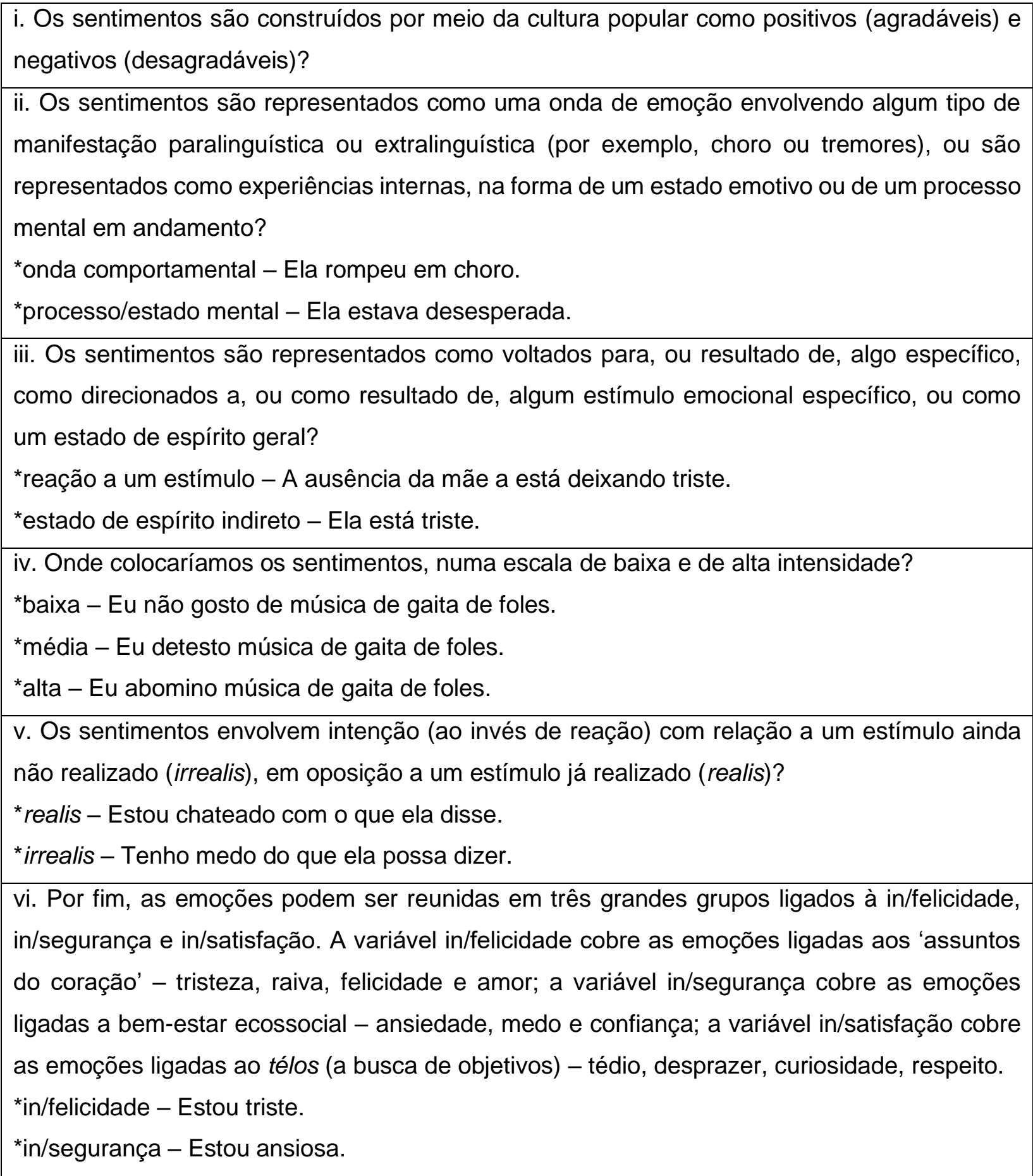

Adaptado de White (2004, p. 186-187)

Quadro 3 - Classificação do afeto em seis fatores

- Julgamento - "é o campo de significados através dos quais construímos nossas posições em relação ao comportamento humano - aprovação/condenação do 
comportamento humano através de referências à aceitabilidade e às normas sociais; avaliações do caráter de alguém, ou do quanto essa pessoa se aproxima das expectativas e exigências sociais" (WHITE, 2004, p. 187). Os julgamentos podem ser de estima social, aqueles relacionados à normalidade/capacidade/tenacidade e de sanção social, relacionados à veracidade/propriedade. Segue exemplo de julgamento de estima social retirado do corpus:

Com aquele ar de importância e de grandeza que ele nunca poderia ter perdido. (P11, Veja, jun. 1992), p.168.

White (2004) apresenta um quadro de tipologia de julgamentos contendo três colunas: estima social, positiva e negativa. Gonçalves Segundo (2011, p. 173) sugere um quadro contendo outras colunas que consideramos pertinentes: definição e analogia modal, por isso elaboramos a junção das duas propostas e obtivemos o resultado a seguir. 


\begin{tabular}{|c|c|c|c|c|}
\hline Estima social & Definição & $\begin{array}{l}\text { Positiva } \\
\text { (admiração) }\end{array}$ & $\begin{array}{l}\text { Negativa } \\
\text { (crítica) }\end{array}$ & $\begin{array}{l}\text { Analogia } \\
\text { modal }\end{array}$ \\
\hline $\begin{array}{l}\text { Normalidade } \\
\text { (costume) } \\
\text { "O } \\
\text { comportamento } \\
\text { do indivíduo é } \\
\text { pouco usual, } \\
\text { especial, } \\
\text { comum?" }\end{array}$ & $\begin{array}{l}\text { Grau de } \\
\text { especialidade } \\
\text { ou usualidade }\end{array}$ & $\begin{array}{l}\text { padrão, } \\
\text { corriqueiro, } \\
\text { mediano, } \\
\text { sortudo, } \\
\text { felizardo, } \\
\text { elegante }\end{array}$ & $\begin{array}{l}\text { excêntrico, } \\
\text { estranho, } \\
\text { dissidente, } \\
\text { azarado, } \\
\text { infeliz, cafona, } \\
\text { obscuro }\end{array}$ & $\begin{array}{l}\text { Usualidade } \\
\text { (às vezes/ } \\
\text { frequentemente/ } \\
\text { sempre) }\end{array}$ \\
\hline $\begin{array}{l}\text { Capacidade } \\
\text { "O indivíduo é } \\
\text { capaz, } \\
\text { competente?" }\end{array}$ & $\begin{array}{l}\text { Grau de } \\
\text { capacidade ou } \\
\text { competência }\end{array}$ & $\begin{array}{l}\text { habilidoso, } \\
\text { inteligente, } \\
\text { engenhoso, } \\
\text { atlético, forte, } \\
\text { poderoso, } \\
\text { lúcido, } \\
\text { centrado }\end{array}$ & $\begin{array}{l}\text { burro, lento, } \\
\text { simplório, } \\
\text { desajeitado, } \\
\text { fraco, sem } \\
\text { coordenação, } \\
\text { insano, } \\
\text { neurótico }\end{array}$ & $\begin{array}{l}\text { Dinâmico } \\
\text { (poder/ } \\
\text { conseguir/ser } \\
\text { capaz de) }\end{array}$ \\
\hline $\begin{array}{l}\text { Tenacidade } \\
\text { (resolução) } \\
\text { “O indivíduo é } \\
\text { confiável, bem } \\
\text { disposto?” }\end{array}$ & $\begin{array}{l}\text { Grau de } \\
\text { resolução ou } \\
\text { perseverança }\end{array}$ & $\begin{array}{l}\text { corajoso, } \\
\text { valente, } \\
\text { heroico, } \\
\text { confiável, } \\
\text { responsável, } \\
\text { incansável, } \\
\text { decidido, } \\
\text { perseverante }\end{array}$ & $\begin{array}{l}\text { covarde, } \\
\text { impetuoso, } \\
\text { cabisbaixo, } \\
\text { pouco } \\
\text { confiável, } \\
\text { irresponsável, } \\
\text { distraído, } \\
\text { preguiçoso, } \\
\text { disperso. }\end{array}$ & $\begin{array}{l}\text { Inclinação } \\
\text { (querer/ansiar/ } \\
\text { estar/ } \\
\text { determinado a) }\end{array}$ \\
\hline Sansão social & Definição & $\begin{array}{l}\text { Positiva } \\
\text { (elogio) }\end{array}$ & $\begin{array}{l}\text { Negativa } \\
\text { (condenação) }\end{array}$ & $\begin{array}{l}\text { Analogia } \\
\text { modal }\end{array}$ \\
\hline $\begin{array}{l}\text { Veracidade } \\
\text { (verdade) } \\
\text { "O indivíduo é } \\
\text { honesto?" }\end{array}$ & $\begin{array}{l}\text { Grau de } \\
\text { honestidade } \\
\text { ou } \\
\text { sinceridade }\end{array}$ & $\begin{array}{l}\text { honesto, } \\
\text { sincero, } \\
\text { verdadeiro, } \\
\text { autêntico, } \\
\text { genuíno, } \\
\text { franco, direto }\end{array}$ & $\begin{array}{l}\text { falso, } \\
\text { desonesto, } \\
\text { impostor, } \\
\text { enganador, } \\
\text { enrolador }\end{array}$ & $\begin{array}{l}\text { Probabilidade } \\
\text { Epistêmico } \\
\text { (possível/ } \\
\text { provável/certo) }\end{array}$ \\
\hline $\begin{array}{l}\text { Propriedade } \\
\text { (ética) } \\
\text { “O indivíduo é } \\
\text { ético, acima da } \\
\text { crítica? }\end{array}$ & $\begin{array}{l}\text { Grau de } \\
\text { transparência } \\
\text { ética ou } \\
\text { civismo }\end{array}$ & $\begin{array}{l}\text { bom, virtuoso, } \\
\text { respeitador } \\
\text { das leis, justo, } \\
\text { carinhoso, } \\
\text { sensível, } \\
\text { respeitoso }\end{array}$ & $\begin{array}{l}\text { mau, imoral, } \\
\text { lascivo, } \\
\text { corrupto, } \\
\text { injusto, cruel, } \\
\text { mesquinho, } \\
\text { bruto, } \\
\text { opressor }\end{array}$ & $\begin{array}{l}\text { Obrigação } \\
\text { Deôntico } \\
\text { (permitido/ } \\
\text { esperado/ } \\
\text { exigido) }\end{array}$ \\
\hline
\end{tabular}

Adaptado de White (2004) e Gonçalves Segundo (2011)

Quadro 4 - Tipologia de julgamentos

- Apreciação - terceiro subsistema da Atitude. Gonçalves Segundo (2011, p. 174) resume as apreciações como aquelas "que constroem avaliações, em geral, de 
caráter estético ou de valor social. Incidem sobre fenômenos semióticos ou naturais, de acordo com os valores de determinado campo".

Em Martin e White (2005, p. 56, grifo dos autores), encontramos uma subdivisão para a apreciação, "em termos gerais, as apreciações podem ser divididas em nossas 'reações' às coisas, (elas captam a nossa atenção; elas nos agradam?) sua 'composição' (equilíbrio e complexidade) e seu 'valor' (como inovador, autêntico, oportuno etc.)"12. Segue exemplo retirado do corpus:

Ex.: Bonito \& Inteligente: Extrato Real Descomplicado. Bonito porque tem a aparência elegante como nenhum outro tem. E inteligente porque descomplica a sua vida. (P4, Claudia, out. 1979), p. 161.

Os autores sugerem o seguinte quadro de tipos de apreciação:

12 "In general terms appreciations can be divided into our 'reactions' to things (do they catch our attention; to they please us?), their 'composition' (balance and complexity), and their 'value' (how innovative, authentic, timely, etc.)". [N.A.: Tradução livre) 


\begin{tabular}{|l|l|l|}
\hline & \multicolumn{1}{|c|}{ Positivo } & \multicolumn{1}{c|}{ Negativo } \\
\hline reação: impacto & $\begin{array}{l}\text { chamativo, cativante, } \\
\text { atrativo, } \\
\text { fascinante, excitante, } \\
\text { comovente, animado, } \\
\text { dramático, intenso, notável, } \\
\text { surpreendente, sensacional }\end{array}$ & $\begin{array}{l}\text { sem-graça, cansativo, seco, } \\
\text { ascético, pouco atraente, } \\
\text { unidimensional, previsível, } \\
\text { monótono, banal, comum }\end{array}$ \\
\hline $\begin{array}{l}\text { reação: qualidade } \\
\text { 'Eu gostei disso?' }\end{array}$ & $\begin{array}{l}\text { adorável, lindo, esplêndido, } \\
\text { atraente, encantador, bem- } \\
\text { vindo }\end{array}$ & $\begin{array}{l}\text { comum, feio, grotesco, } \\
\text { repulsivo, revoltante, } \\
\text { repelente }\end{array}$ \\
\hline $\begin{array}{l}\text { composição: equilíbrio } \\
\text { elaborado?' }\end{array}$ & $\begin{array}{l}\text { equilibrado, harmonioso, } \\
\text { unificado, simétrico, bem } \\
\text { proporcionado, consistente, } \\
\text { bem elaborado, lógico, bem } \\
\text { formado, curvilíneo, } \\
\text { longilíneo }\end{array}$ & $\begin{array}{l}\text { sem equilíbrio, discordante, } \\
\text { irregular, torto, imperfeito, } \\
\text { contraditório, desorganizado, } \\
\text { mau formado, amorfo, } \\
\text { retorcido }\end{array}$ \\
\hline $\begin{array}{l}\text { composição: } \\
\text { complexidade } \\
\text { 'Isso foi difícil de } \\
\text { entender?' }\end{array}$ & $\begin{array}{l}\text { simples, puro, elegante, } \\
\text { lúcido, claro, preciso, } \\
\text { intrincado, rico, detalhado, } \\
\text { preciso }\end{array}$ & $\begin{array}{l}\text { complicado, extravagante, } \\
\text { bizantino, misterioso, } \\
\text { obscuro, vago, simples, } \\
\text { monolítico, simplista }\end{array}$ \\
\hline $\begin{array}{l}\text { valorização: } \\
\text { 'Isso valeu a pena?' }\end{array}$ & $\begin{array}{l}\text { penetrante, profundo, } \\
\text { inovador, original, criativo, no } \\
\text { tempo certo, há muito } \\
\text { esperado, divisor de águas, } \\
\text { inimitável, excepcional, único, } \\
\text { autêntico, real, genuíno, } \\
\text { valioso, de valor incalculável, } \\
\text { meritório }\end{array}$ & $\begin{array}{l}\text { superficial, reducionista, } \\
\text { insignificante, derivativo, } \\
\text { convencional, prosaico, } \\
\text { ultrapassado, fora de época, } \\
\text { datado, feito em série, } \\
\text { ordinário, comum, falso, } \\
\text { espalhafatoso, sem valor, de } \\
\text { má qualidade, caro demais }\end{array}$ \\
\hline
\end{tabular}

Fonte: White (2004, p. 191)

Quadro 5 - Tipologia de apreciações

Apesar da divisão proposta nos quadros apresentados, "nem sempre, no entanto, as fronteiras entre as categorias atitudinais são claras. Há casos de ambiguidade ou dupla inscrição, além de formas linguísticas que sofrem uma mudança em seu estatuto avaliativo mediante o contexto" (GONÇALVES SEGUNDO, 2011, p. 192). Em outras palavras, assim como já mencionamos anteriormente, tanto as estruturas das categorias de afeto como de julgamento e de apreciação remetem a inúmeras possibilidades léxicogramaticais, são mutáveis, portanto, não podem ser pensadas como fixas. 


\subsubsection{Engajamento}

Para uma adequada compreensão do engajamento, é necessário considerar que "o tratamento dado aos recursos de posicionamento subjetivo dentro da abordagem da valoração tem como base a noção de que todos os enunciados verbais são, em última análise, dialógicos" (WHITE, 2004, p. 192).

O engajamento, assim como as categorias apresentadas anteriormente, é subdivido em enunciados monoglóssicos e heteroglóssicos, mas centra-se nos recursos da heteroglossia que são aqueles que "possibilitam à voz autoral alinhar-se ou desalinhar-se, em vários graus, em relação aos consumidores textuais visados ou ideais" (GONÇALVES SEGUNDO, 2011, p. 177). A heteroglossia ainda se subdivide em expansão dialógica e contração dialógica.

- Expansão dialógica - está relacionada ao sistema interpessoal no tocante ao reconhecimento e aceitação de vozes e posicionamentos dialógicos alternativos nos textos (GONÇALVES SEGUNDO, 2011). Podem ser subdistribuídos em mecanismos de: ponderação (entertain), quando se apresenta uma alternativa entre outras, invoca-se as demais possibilidades, mas não se rejeita outras alternativas. São exemplos de ponderação as expressões: aparentemente, talvez, provavelmente, pode ser que; atribuição (atribution), que se relaciona ao apoio a uma proposta/proposição atribuída a uma voz externa, considerando outras alternativas dialógicas. A atribuição pode ser de reconhecimento - quando a voz autoral assume uma atitude de neutralidade em relação ao conteúdo do discurso relatado. São expressões de reconhecimento: segundo $X$, de acordo com $X$, na opinião de X, X disse que; e de distanciamento - quando a voz autoral se distancia do conteúdo do discurso relatado, ou seja, conforme Gonçalves Segundo (2011, p. 179) "quando ocorre a rejeição da voz autoral em relação ao discurso da fonte externa [...] o que possibilita vincular resistência do escritor em relação às proposições da fonte, de modo a procurar alinhar o leitor a também resistir às 
proposições valorativas desses atores sociais". São exemplos de distanciamento: ouvi dizer que, alguns dizem que, $X$ alega que, correm rumores que.

Ao apresentar as categorias da heteroglassia, White (2004, p. 194) diferencia expansão dialógica de contração dialógica afirmando que:

[...] elas são divididas em duas categorias gerais de acordo com um amplo eixo de variação em termos de funcionalidade retórica: são caracterizadas como geradoras ou de 'expansão dialógica' ou de 'contração dialógica'. A diferença está no grau no qual um enunciado, por meio de uma ou mais palavras, levanta posições e vozes dialógicas alternativas (expansão dialógica), ou, ao contrário, age no sentido de desafiar, dispensar ou restringir o escopo dessas posições ou vozes (contração dialógica).

- Contração dialógica, que se divide em refutação e declaração.

- Refutação (disclaim): negação - segundo White (2004, p. 198), "a negação é um recurso utilizado para introduzir uma posição alternativa positiva no diálogo, reconhecê-la e engajar-se com ela, para então rejeitá-la". São exemplos de negação expressões como não, nunca, ninguém. A refutação também pode ter estruturas de contraexpectativa, que se alinham ao consumidor textual quando a inovação dialógica é construída como esperada não só pela voz autoral como também pelo leitor ideal, de forma que a proposição poderá remeter tanto a elemento de surpresa como de exceção para os dois - voz autoral e leitor ideal. Exemplos de expressões de contraexpectativa são as conjunções concessivas ou adversativas: mas, no entanto, embora, entre outras.

- Declaração (proclaim) - apresenta uma posição como altamente pertinente para descartar outras não pertinentes/possíveis. Exemplos de declaração por concordância: é claro, naturalmente, obviamente; por afirmação: afirmo que, a verdade é que, não há dúvida de que; por endosso: $X$ provou que, $X$ mostrou que, $X$ demonstrou que, revela $X$. Segue exemplo de contração dialógica retirada do corpus:

Ex.: A gente fala o que os outros bancos não falam: cheque especial foi feito para emergências. (P18, Exame, jul. 2018), p. 175. 


\subsubsection{Gradação}

Chegamos, por fim, à terceira grande categoria da teoria da valoração (avaliabilidade), a gradação.

Os recursos de gradação atenuam ou potencializam fenômenos. A gradação opera sob dois eixos:

- foco, que "concerne ao grau de comprometimento da voz autoral em relação à precisão ou à prototipicalidade das categorias com que opera [...] aplica-se a elementos lexicais que, de um ponto de vista experiencial, não se constituem como escalares" (GONÇALVES SEGUNDO, 2011, p. 184), mas deixam as definições mais claras (precisão) ou mais obscuras e amenas (abrandamento).

Ex.: É um crédito essencial que o Banco Real tem exclusivamente para seus clientes. (P9, Exame, maio 1982)

- força, que, segundo entendimento do mesmo autor, "relaciona-se à intensificação e à quantificação das categorias. [...] a força opera com categorias escaláveis por natureza [...] recobre posturas autorais relacionadas à intensidade e quantidade." (idem, ibidem). Exemplos de intensidade e quantidade: meio, muito, extremamente, pouco, demais etc. No corpus, encontramos o seguinte exemplo de gradação relacionado ao eixo força:

Ex.: Mais um banco de investimentos e quatro empresas de crédito, financiamento e investimentos, formando um dos maiores grupos financeiros do país. (P2, Veja e Leia, set. 1969)

Para Gonçalves Segundo (2011, p. 185), "os elementos de gradação podem ocupar um papel fundamental na configuração retórica, tanto no âmbito do convencimento e da persuasão, quanto do comprometimento e autoridade, intimamente conectados aos dois processos anteriores". 
Mesmo concordando com as palavras do pesquisador e reconhecendo o valor imensurável de todos os sistemas e subsistemas da teoria da valoração (ou avaliatividade) - atitude, engajamento e gradação - para as análises que ora iniciamos, iremos nos deter somente nas "três grandes dimensões relacionadas ao posicionamento subjetivo diante da realidade, envolvendo, de modo geral, o emocional, o comportamental e o estético, que instanciam, respectivamente, valores de afeto, julgamento e apreciação" (GONÇALVES SEGUNDO, 2011, p. 170), abrangidas pelo sistema da atitude. 


\section{DESCRIÇÃO E ANÁLISE DO CORPUS}

Retomando o que já foi mencionado na introdução desta tese, as propagandas selecionadas para este trabalho são da marca Banco da Lavoura, Banco Real e Santander e somam trinta e sete, dentre elas, dezenove foram escolhidas para exemplificar as funções e categorias da gramática visual e dezoito para constituir nosso corpus - denominadas P1 a P18, divididas em seis décadas, portanto, três propagandas por década, que passamos a descrever e analisar neste capítulo.

Iniciamos esta seção com um panorama genérico do suporte revista impressa para depois descrever especificamente cada um dos três títulos selecionados para esta análise.

\subsection{O suporte: revista impressa}

Apesar dos avanços tecnológicos e do grande número de computadores, tablets, notebooks e smartphones que possibilitam a leitura de jornais, livros, revistas e pages, as revistas impressas continuam ocupando lugar nas bancas e revistarias. A oferta inclui revistas técnicas, especializadas e de conhecimentos gerais direcionadas às mais variadas camadas da população: crianças, jovens, adolescentes, homens, mulheres, idosos, classe $\mathrm{C}$, elites, grupos de profissionais, nichos etc.

Há revistas em quadrinhos, de telenovelas, de variedades, de informações e até revistas científicas. Os formatos das revistas variam, por exemplo, entre 13,5 × 18,5 cm, $20,2 \times 26,6$ e $25 \times 30 \mathrm{~cm}$. A medida mais comum é a de $20,2 \times 26,6$, como são hoje as constituintes do corpus desta pesquisa.

Quando intencionamos selecionar o período de 1960 até 2018, entendemos que seis décadas seriam um tempo razoável para encontrar nos discursos veiculados nas propagandas alterações/transformações/peculiaridades significativas. Ao mesmo tempo, deparamo-nos com a dificuldade de encontrar revistas impressas que perpassassem 
todo o período que idealizamos. Encontramos registros sobre a possível primeira revista brasileira publicada em 1812 (As variedades ou Ensaios de Literatura) e outras que a seguiram, como: O Espelho Diamantino, Espelho das Brasileiras, Jornal das Senhoras etc.

As primeiras revistas publicadas no Brasil tiveram existência curta, algumas de poucas edições, outras duraram alguns anos e poucas persistem até a atualidade. Na pesquisa realizada, percebemos que permanecem em circulação apenas alguns títulos publicados a partir de 1942, os demais, do período anterior, deixaram de circular; assim, atualmente, ainda encontramos Seleções (1942), Capricho (1952), Manequim (1959). Nos anos 1960, concentra-se o maior número de títulos de revistas que persistem ainda hoje e é dentre eles que se encontram as que compõem o corpus sob análise.

Selecionamos três revistas, a revista Claudia - direcionada ao público feminino adulto, lançada em 1961, a revista Veja - direcionada ao público geral adulto, lançada em 1968, e a revista Exame - direcionada ao público executivo, lançada em 1967.

\subsubsection{Revista Claudia}

Claudia é uma revista lançada em 1961, pela Editora Abril, "tendo como públicoalvo as mulheres da classe média urbana que possuíam poder aquisitivo para comprar

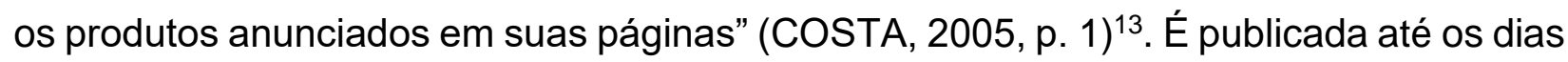
atuais no formato mediano $20,2 \times 26,6$, assim como a maioria das revistas, e impressa em cores em papel de excelente qualidade. As capas tem layout padrão, com o título no alto e uma imagem de mulher, sempre uma das beldades da época. Mulheres magras, lindíssimas e famosas, como as contemporâneas Camila Pitanga, Mariana Ximenes, Taís Araújo, Carolina Ferraz, Adriana Esteves, Luiza Brunet, Rosangela Moro, entre outras.

Claudia conta, normalmente, com 194 páginas, divididas entre propagandas, matérias, artigos, reportagens, horóscopo. As seções abordam reportagens de capa,

${ }_{13}$ Disponível em: <http://anais.anpuh.org/wp-content/uploads/mp/pdf/ANPUH.S23.1416.pdf>. Acesso em: 13 fev. 2017. 
inspiração, moda, beleza, comportamento e gente, casa e família, comida \& bebida, sempre em Claudia (subdivida em Eu e você, Claudia digital, sua opinião, onde encontrar, horóscopo). Matérias, artigos e reportagens ocupam por volta de sessenta páginas da revista (30\%, aproximadamente), as demais são destinadas às propagandas diretas ou indiretas. Por propagandas diretas entendemos aquelas que são assinadas por uma empresa determinada; as indiretas são aquelas que ensinam a se maquiar, apresentam os produtos, informam os preços e onde adquiri-los, o mesmo se repete com roupas, cabelos, comidas etc. Os anunciantes habituais são: Natura, C\&A, Vigor, Dudalina, O Boticário, Arezzo, Seara, MMartan, Gregory, Colgate, Pandora, Zara, Ana Hickmann.

A Editora Abril definiu em outubro de 1961, para sua nova publicação, uma leitora
que não sonha, consome. Mostrando em todas as suas matérias produtos que a
mulher encontraria facilmente em qualquer lugar do Brasil, funcionando como um
verdadeiro guia de compras, influencia suas leitoras a adotarem determinado
padrão de consumo, associando o ato de consumir ao de ser moderno. (COSTA,
2005, p. 1)

A Editora Abril sempre esteve muito perto da mulher brasileira. A primeira revista feminina que lançou foi Claudia, que focava inicialmente a dona de casa e, posteriormente, evoluiria para acompanhar as mudanças do perfil desse público. Para se manter 50 anos no mercado e ainda ser a maior revista feminina brasileira, Claudia teve de se adaptar às mudanças do tempo e se adequar às exigências do mercado.

O público leitor da revista, hoje, é bem heterogêneo, englobando todas as faixas etárias, as classes sociais A, B e C, com a maioria concentrada no centro-sul do país, onde está a maior parte da população.

\subsubsection{Revista Veja}

A revista Veja foi lançada em 1968, pela Editora Abril, com a proposta de ser uma revista semanal informativa nos moldes da Time. Seu título original era Veja e Leia. Nos anos iniciais, durante o período de ditadura militar, a revista causou muita polêmica e teve milhares de matérias censuradas, incluindo, uma edição apreendida. 
Na década de 1980, a revista deu início a uma estratégia de conteúdo local com a Veja São Paulo, para cobrir assuntos relevantes da cidade e do contexto urbano, além de roteiros de lazer e gastronomia - a revista patrocina até hoje um dos prêmios mais importantes voltado a restaurantes e bares de São Paulo, o "Comer e Beber". Outros títulos locais vieram anos depois, como Veja Rio, Veja BHe Veja Brasília. Posteriormente, a Editora Abril descontinuou esses títulos (MEIO E MENSAGEM, 12 set. 2018), mantendo somente a versão original.

O foco principal da revista são as matérias sobre política e economia nacionais e internacionais, mas há também reportagens sobre ciência e saúde, grandes e polêmicos acontecimentos e descobertas recentes. O formato é $20 \times 26 \mathrm{~cm}$, a qualidade de impressão é boa, mas inferior à da revista Claudia que descrevemos anteriormente.

As propagandas mais frequentes nas páginas da revista são as de cartões de crédito, de automóveis, de telefonia celular, de combustíveis e de instituições financeiras.

\subsubsection{Revista Exame}

A revista Exame, também publicada pela Editora Abril, hoje é considerada a maior e mais influente publicação de negócios e economia do Brasil. A marca Exame contempla o site exame.com, a revista Exame e o anuário Melhores e Maiores, que é o principal ranking financeiro das grandes empresas no país. "Lançada no Brasil em julho de 1968 $(\mathrm{sic})^{14}$ como caderno especial de economia, finanças e administração, tornou-se publicação autônoma em 1971 e se autodenominou 'revista do executivo'" (RAMOS, 2006, p. 5).

Exame é quinzenal, tem circulação em torno de 150 mil exemplares, sendo 115 mil assinaturas, portanto $76 \%$ de seus exemplares são vendidos por assinatura. A cada 15 dias, Exame chega a aproximadamente 700 mil leitores. Sua missão é levar à comunidade de negócios informações e análises aprofundadas sobre temas como estratégia, marketing, gestão, consumo, finanças, recursos humanos e tecnologia.

\footnotetext{
${ }^{14}$ No site da Exame, consta 1967 como ano de lançamento da revista.
} 
Segundo uma pesquisa do instituto Ipsos-Marplan, Exame é lida por 91\% dos presidentes das 500 maiores empresas instaladas no Brasil.

O formato da revista $20,2 \times 26,6$, a qualidade do papel e da impressão também são inferiores aos da revista Claudia, no entanto, das 90 páginas internas, somente 11 , aproximadamente, são dedicadas às propagandas. As demais são ocupadas por matérias, artigos e reportagens sobre agronegócio, gestão, pequenas e médias empresas (PME), internet, economia, crise e grandes empresas nacionais e internacionais. As seções são nomeadas: Brasil, Negócios, Sustentabilidade, Negócios Globais, Tecnologia, Especial, Capa, Sete Perguntas e outras seções menores, como: Carta Exame, Cartas \& E-mails, Primeiro lugar, Outro Ângulo, Só no Brasil, Vida Real, Como Fazer, Visão Global e Seu dinheiro.

Contrariamente à revista Claudia, a Exame traz propagandas de bancos, de automóveis, empreendimentos, computadores, eletrônicos, roupas sociais. Os anunciantes que circulam pelas páginas da revista, são: Itaú, Jaguar, Coelho da Fonseca, HP, Smartphone Congress, Aramis.

\subsection{Propagandas de instituições financeiras em revistas dos séculos XX e XXI: análise do corpus}

Apresentamos neste item as propagandas do Banco da Lavoura/Banco Real/Banco Santander publicadas nas revistas Veja, Claudia e Exame. Nossa busca foi realizada em revistas impressas, arquivadas na Hemeroteca da Biblioteca Mário de Andrade, no Centro da cidade de São Paulo, na Biblioteca da FEA/USP, na Biblioteca da FGV/SP e em sites especializados em propagandas de revistas.

Numa perspectiva diacrônica, ao final das análises, pretendemos verificar se o contexto sócio-histórico-econômico influencia a seleção de recursos multimodais selecionados pelo anunciante e se as revistas - Claudia, Veja, Exame - e seus distintos públicos-alvo - feminino, geral e executivo - registraram mudanças nos discursos das 
instituições financeiras e na imagem de si construída pelo Banco da Lavoura/Banco Real/Santander, por isso, apresentamos em cada década um breve contexto histórico e econômico do país e o cenário das instituições financeiras.

\subsubsection{Década de 1960}

Iniciamos nossa análise com três propagandas, sendo uma da revista Claudia (agosto de 1962), outra da revista Veja (setembro de 1969) e a outra merece um esclarecimento: a revista Exame, apesar de ter sido lançada em 1968, só começou a circular como revista autônoma em 1971, como já mencionado anteriormente. Em nossas buscas pelo corpus, só localizamos as primeiras versões dessa revista na Hemeroteca da Biblioteca Mario de Andrade, mas não pudemos consultá-las, pois, de acordo com a instituição, havia apenas "publicações em fragmentos". Nos outros arquivos, encontramos somente exemplares a partir dos anos 1970. Entretanto, há informações da Editora Abril de que a propaganda que denominamos P2 circulou em todas as revistas de economia e negócios da época, portanto, tudo indica que tenha circulado na Exame. 


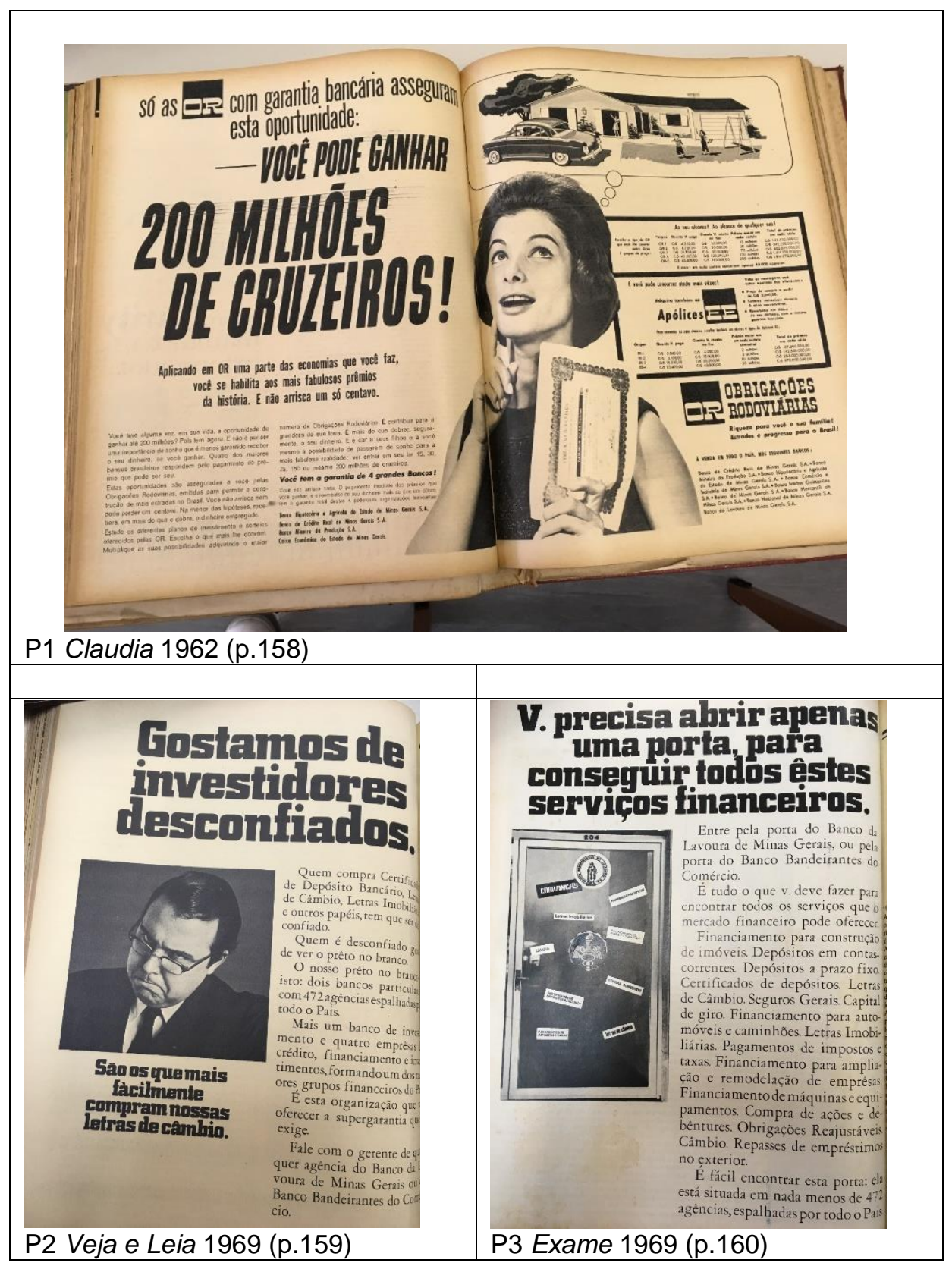

Figura 25 - Propagandas - anos 1960

\subsubsection{Breve contexto histórico do Brasil na década de 1960}

Nova década, novos tempos para o país. A primeira novidade era a construção de Brasília - uma nova capital para o Brasil; a segunda era a revalorização do interior com 
o início de uma prévia da reforma agrária; a terceira era o avanço no setor de energia elétrica que atingia altos níveis de produção de quilowatts; depois a eleição e renúncia de Jânio de Quadros e a posse de João Goulart, que desagradava tanto as elites e as lideranças políticas da época quanto os militares.

Em 1964, encerra-se o governo Goulart e surge o regime que nomeia uma sucessão de presidentes militares e, com eles, a cassação de políticos, professores, cientistas, cantores; a luta armada; a repressão e a censura. De acordo com Fausto (2006, p. 459), "[...] A constituição de 1967 incorporou a legislação que ampliara os poderes conferidos ao Executivo, especialmente em matéria de segurança nacional, mas não manteve os dispositivos excepcionais que permitiriam novas cassações de mandatos, perdas de direitos políticos etc.".

\subsection{O cenário das instituições financeiras na nova década}

Os bancos viviam exclusivamente de sua clientela, por isso, dedicavam-Ihes atendimento presencial cordial e personalizado. Era função do gerente de agência estudar a situação de cada cliente e, a partir de sua reputação no mercado, ou seja, nome e conceito que este tinha na praça, conceder-lhe o melhor produto bancário disponível na época. Os funcionários dos bancos trabalhavam mais de 12 horas diárias para realizar os trabalhos burocráticos, que eram basicamente manuais (preenchimento de formulários, anotações em fichas de papel), contavam com pouquíssimas máquinas registradoras e de autenticação mecânica.

Nessa década, incentivava-se a abertura de novas contas correntes e o aumento

nos depósitos bancários. O público-alvo dos bancos, no início dos anos 1960, era a pessoa física da classe média e assalariada, pois, até então, seu público eram as elites e as empresas.

Em 1964, ocorre a reforma bancária e "criaram-se o Banco Central do Brasil e o Conselho Monetário Nacional”, segundo Brandão (1995, p. 63). Esses órgãos tornaramse responsáveis pela fixação de taxas de juros, pelas regras de concessão de crédito, 
delimitando, portanto, a área de atuação das instituições financeiras, impactando negativamente no relacionamento banco e cliente.

Entretanto, os anos 1960 também representaram para os bancos o início da informatização. Foram criados CPDs - centros de processamento de dados - e implantaram-se novas tecnologias e sistemas, que geravam redução de custos e agilidade nas operações, resgatando a credibilidade dos bancos junto aos clientes. No final da década, os bancos já contavam até com alguns computadores.

Nas instituições financeiras, a grande revolução dos anos 1960 foi o fato de as mulheres casadas passarem a abrir conta-corrente nos bancos, mesmo sem autorização dos maridos, conquista dos movimentos de emancipação feminina - a chamada Segunda Onda do Movimento Feminista. Conforme Brandão (1995, p. 61): "A partir de 1962, [...] as mulheres casadas puderam abrir contas em bancos, mesmo sem a autorização dos maridos. Essa proibição era prevista em lei".

\subsection{A desigualdade de gêneros e a luta das mulheres}

A mulher ocupou o lugar de dona de casa, de esposa e de mãe, exclusivamente, por longo período na história. No Brasil não foi diferente. Não tinha direito ao voto, não podia estudar, não podia andar desacompanhada pelas ruas; enfim, não tinha autonomia nem liberdade, sendo vítima de injustiças e da dominação masculina. A mulher teve que reivindicar sua liberdade e até mesmo sua identidade como ser humano.

A desigualdade fez com que a mulher, a partir do século XVIII, iniciasse a luta pelos seus direitos para além do espaço doméstico (CISNE, 2014), como o direito à participação na vida pública, ao trabalho remunerado e ao acesso à educação.

Na segunda metade do século XIX, a mulher passa a se organizar em grupos e a reivindicar direitos políticos para votar e concorrer a cargos eletivos - movimento sufragista - que configurou a Primeira Onda do Movimento Feminista.

O processo de aceleração econômica do Brasil, nesse período, gerou considerável aumento no número de mulheres que passaram a trabalhar fora de casa. Mas essa 
conquista não anulou as funções domésticas da mulher. $\mathrm{Na}$ verdade, o complexo processo de apropriação empreendido pelas mulheres dos espaços públicos:

[...] caracterizou-se como um movimento essencialmente contraditório, porque ao mesmo tempo que os personagens femininos ocuparam inexoravelmente lugares antes restritos aos homens, amiudaram-se os discursos oriundos de variados campos de saber propugnando justamente a restrição desse sexo ao império do lar. (CAMPOS, 2009, p. 82)

Os lugares ocupados pela mulher no mercado de trabalho - docência primária, enfermagem, telefonia e secretária - também geraram contradições, pois essas funções "requeriam qualidades supostamente constitutivas do sexo frágil, como paciência, docilidade, sensibilidade e disposição intrínseca à submissão", segundo Campos (2009, p. 83).

Mundialmente, o movimento feminista foi se transformando e se dividindo no decorrer de sua evolução. Embora tenha havido três correntes que se opunham entre si - feminismo radical, feminismo socialista e feminismo liberal - todas elas tinham em comum a busca pela redução da desigualdade entre homens e mulheres e a luta contra o sistema patriarcal, cerne da Segunda Onda do Movimento Feminista (final dos anos 1960). Com isso, as mulheres conquistaram um papel diferente nas propagandas de bancos, ou seja, passaram a ser reconhecidas como donas de suas próprias contas correntes e as propagandas passaram a se dirigir diretamente a elas como "você", como veremos no exemplo $\mathrm{P} 1$, objeto de nossas análises.

Opostamente a isso, em propagandas do início da década de $1960^{15}$, podemos observar a mulher num papel de coadjuvante, ela vai se casar, mas a propaganda é direcionada ao pai, que é o cliente do Banco e quem vai arcar com as despesas do casamento. A mulher aparece como "ela", "sua filha", como no exemplo a seguir e em outras diversas propagandas do Banco da Lavoura dessa mesma época, em que a mulher não possuía conta-corrente e dependia totalmente do pai ou do esposo nesse quesito.

\footnotetext{
${ }^{15}$ As propagandas constam dos Anexos no final desta tese.
} 


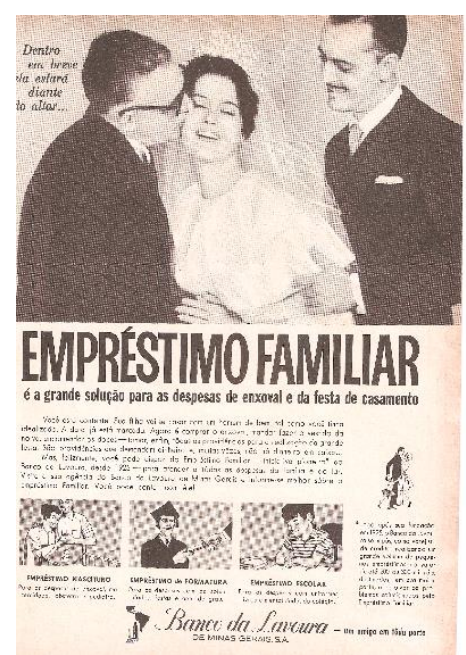

Figura 26 - A mulher na propaganda - início dos anos 1960

(Seleções, jul. 1960), p. 199.
Dentro em breve ela estará diante do altar...

\section{EMPRÉSTIMO FAMILIAR ${ }^{16}$}

é a grande solução para as despesas de enxoval e da festa de casamento

Você está contente. Sua filha vai se casar com um homem de bem, tal qual você tinha idealizado. A data já está marcada. Agora é comprar o enxoval, mandar fazer o vestido, encomendar os doces - tomar, enfim, tôdas as providências para a realização da grande festa. São providências que demandam dinheiro e, muitas vêzes, não há dinheiro em caixa.

Mas não se preocupe com isso. O Empréstimo Familiar - iniciativa pioneira* do Banco da Lavoura, desde 1925 - resolve êsse problema para você. Faça uma visita à sua agência do Banco da Lavoura de Minas Gerais e venha conversar conosco sôbre o Empréstimo Familiar. Você pode contar com êle!

BANCO DA LAVOURA - um amigo em tôda parte

\subsubsection{Análise das propagandas dos anos 1960}

As três propagandas selecionadas dos anos 1960 são em preto e branco, algo comum pelas limitações gráficas e de custo da época. Nesse período, as capas das revistas eram coloridas, mas as páginas internas sempre em preto e branco, com raríssimas exceções como as propagandas das marcas Avon, Brastemp, Santista, Volkswagem, entre outras. As divulgações de bancos eram em preto e branco, continham bastante texto e algo comum às três é que o nome do banco aparece no decorrer dos textos, sem nenhum destaque.

A primeira propaganda selecionada da revista Claudia, de 1962, é de página dupla, mostra em destaque a imagem de uma mulher elegante, alegre, pensando em bens imóvel e automóvel. O produto é OR Obrigações Rodoviárias, vendidas em todo o

\footnotetext{
${ }^{16}$ Nesta e em outras propagandas, foi mantida a ortografia da época.
} 
país em instituições financeiras como o Banco da Lavoura de Minas Gerais S/A, último na relação constante do rodapé da página, em letras pequenas, sem destaque.

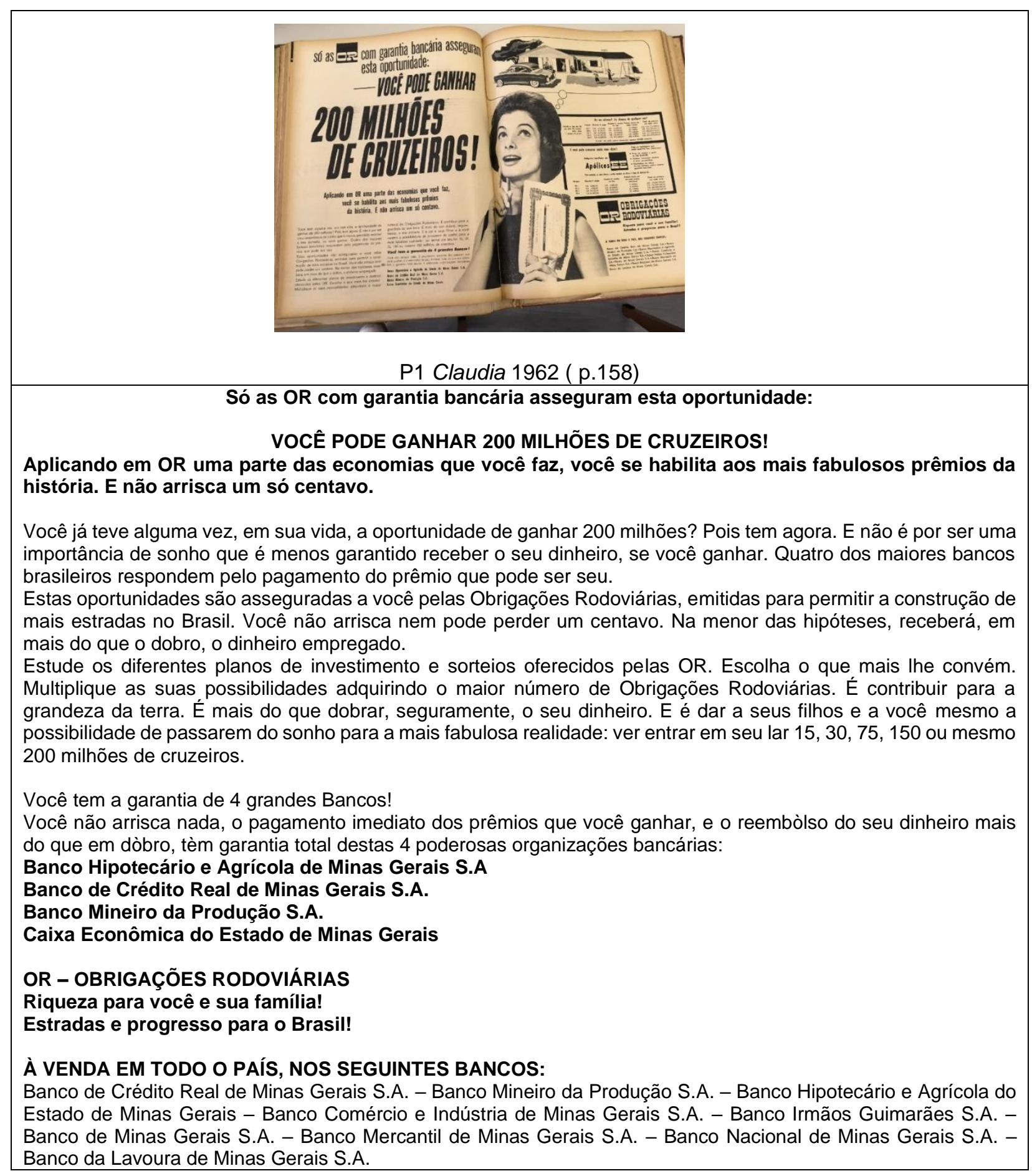


Trata-se de um texto multimodal, em que observamos texto, imagem, tabela, logomarca, a imagem visual se soma à linguagem verbal e ambas possuem significados que se completam, a fim de produzir efeito de sentido ao leitor, que, no caso, é a mulher de classe média alta - público-alvo da revista em questão - que tem poder aquisitivo para investir em determinado produto, ou seja, as "Obrigações Rodoviárias". O aspecto de persuasão da propaganda parece estar no valor do prêmio da OR que é "200 milhões de cruzeiros!". Assim como o valor é grande, o tamanho das letras e números também é grande no texto multimodal. A expressão "Você pode ganhar" completa o apelo bastante forte de persuadir a mulher a comprar a OR.

Do ponto de vista da GDV, percebemos que, com relação à função de representação, a propaganda apresenta uma representação narrativa acional transacional, em que é possível identificar o alvo do olhar da participante mulher em direção ao participante (meta), que é seu sonho de consumo de conquistar a casa e o automóvel, envoltos em um balão de pensamento que nos remete a identificar outra representação narrativa que é o processo mental, como podemos observar nas indicações a seguir:

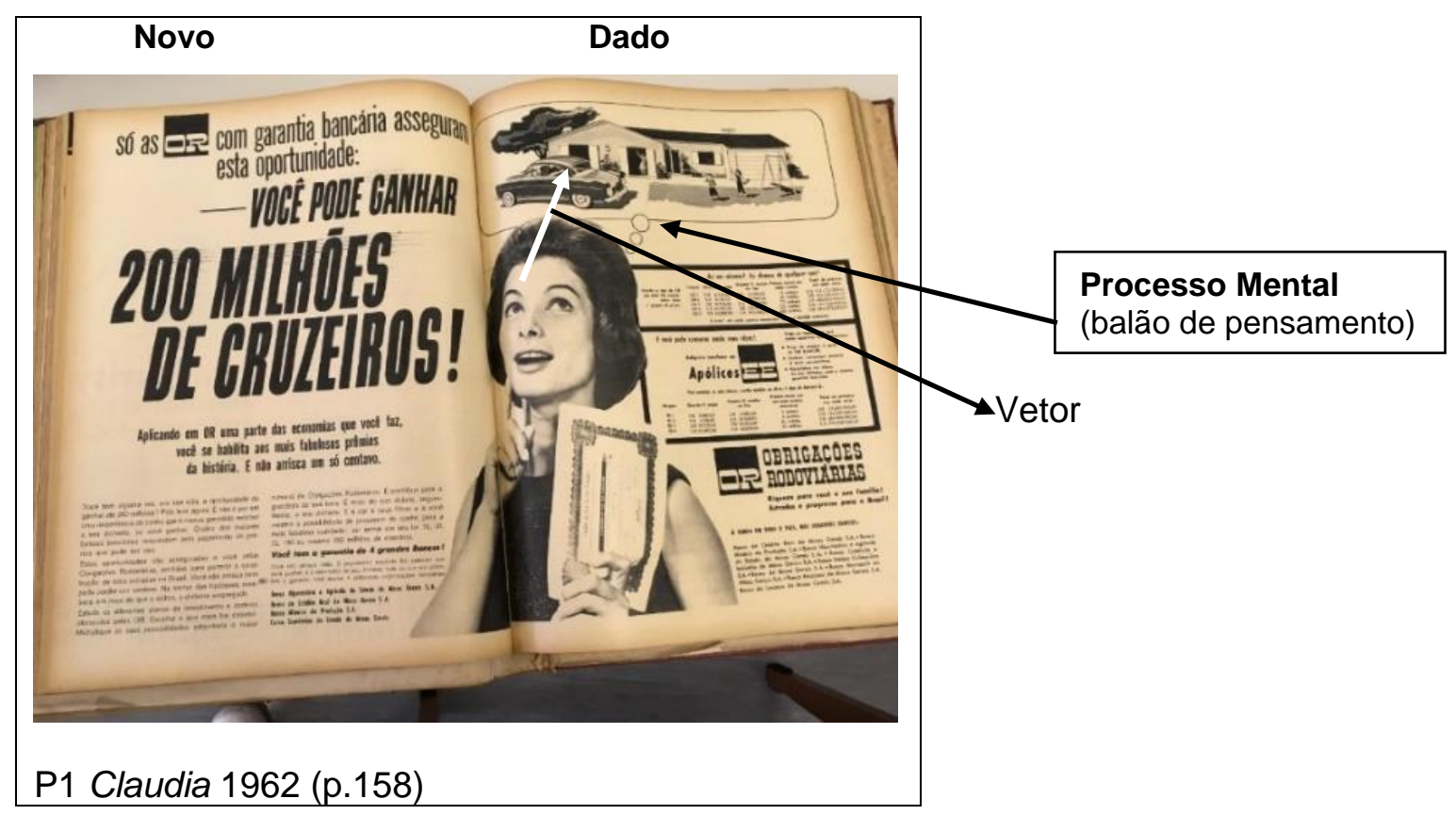

No tocante à função de interação, observamos o contato de oferta, pois a linha do olhar da participante mulher não está dirigida ao leitor, remetendo a uma relação 
impessoal. Observa-se também a distância social e o plano médio/medium shot manifestados entre o participante e o leitor, corroborando a ideia de oferta e demonstrando uma relação de nível apenas social entre participante e leitor. Ainda no âmbito da função de interação, no plano da perspectiva/atitude, o participante é captado por um ângulo de mesma perspectiva, ou seja, de igualdade com o leitor (igual poder).

Quanto à função de composição, o valor da informação ocorre por meio do dado $\times$ novo invertido ${ }^{17}$, pois o dado/conhecido é a mulher sonhando em conquistar bens (casa e carro) a partir do documento em sua mão, representado pela OR, e o novo é a possibilidade de ganhar os "200 milhões de cruzeiros" e, com eles, realizar seus sonhos. A saliência, nesta propaganda, é construída pelo destaque dado ao tamanho da OR e ao valor que ela representa "200 milhões de cruzeiros".

Podemos observar que a propaganda está focada no leitor, mas não se distancia do seu objetivo, que é a valorização do produto para vendê-lo, por isso, apresenta argumentos de persuasão representados pela seleção de um léxico formado por adjetivos de valor de afeto como "fabulosos" prêmios, "importância de sonho", "grandeza" da terra, para valorizar as OR; e ainda "riqueza" para você e sua família, como uma oportunidade/conquista para a mulher, valorizando o leitor.

Com relação à construção da imagem do anunciante - o enunciador, as instituições financeiras -, encontramos valores de apreciação como: "grandes" bancos, "maiores" bancos brasileiros e "poderosas" organizações. Imagem que merece credibilidade e proporciona segurança e garantias aos leitores - o coenunciador, e melhorias para o país, como podemos observar nos seguintes enunciados:

- É mais do que dobrar, seguramente, o seu dinheiro.

- Estas oportunidades são asseguradas a você pelas Obrigações Rodoviárias [...]

- Você tem a garantia de 4 grandes bancos.

- Estradas e progresso para o Brasil!

${ }_{17}$ Novo invertido ocorre quando o dado aparece do lado direito e novo do lado esquerdo da imagem. 
O fato de a propaganda retratar uma mulher como protagonista de uma transação bancária, no início dos anos 1960, mais especificamente 1962, remete-nos a recuperar a situação da mulher, naquela década, que já era de conquistas como poder trabalhar fora e gozar de certa autonomia, porém ainda sem autorização dos maridos para abrir contacorrente em bancos. Na cena enunciativa dessa propaganda veiculada em revista feminina, encontramos um enunciador que se dirige ao coenunciador: a mulher como "você" e um você que "faz", que se "habilita", que "ganha", que "não se arrisca a perder", que "escolhe", "multiplica", remetendo à mulher que está conquistando espaço, autônoma, que trabalha e, por isso, pode sonhar em adquirir bens. No entanto, isso se opõe a "dar aos seus filhos" e conquistar "riqueza para você e sua família", confirmando a imagem da mulher "dona dos seus pensamentos/sonhos", mas que vive para os filhos e para a família. Como podemos constatar nos enunciados a seguir:

- Aplicando em OR uma parte das economias que você faz, você se habilita aos mais fabulosos prêmios da história. E não arrisca um só centavo.

- Escolha o que mais Ihe convém.

- Multiplique as suas possibilidades adquirindo o maior número de Obrigações Rodoviárias.

- E é dar a seus filhos e a você mesmo a possibilidade de passarem do sonho para a mais fabulosa realidade $[\ldots]$

- Riqueza para você e sua família.

Passamos para a análise da propaganda P2, da Veja e Leia, direcionada ao público geral, leitor da revista. A P2 é uma propaganda de página única, impressão preto e branco, texto na maior parte da página e um participante masculino, vestido de terno e gravata, remetendo a um profissional investidor do mercado, com uma expressão peculiar de alguém que desconfia de alguma coisa. $O$ texto no topo corrobora a imagem "investidores desconfiados". O nome da instituição financeira aparece no decorrer do texto sem destaque e, algo que observamos em outras propagandas daquela década, aparecem dois nomes de bancos dividindo a mesma propaganda "Banco da Lavoura de Minas Gerais", "Banco Bandeirantes do Comércio". 


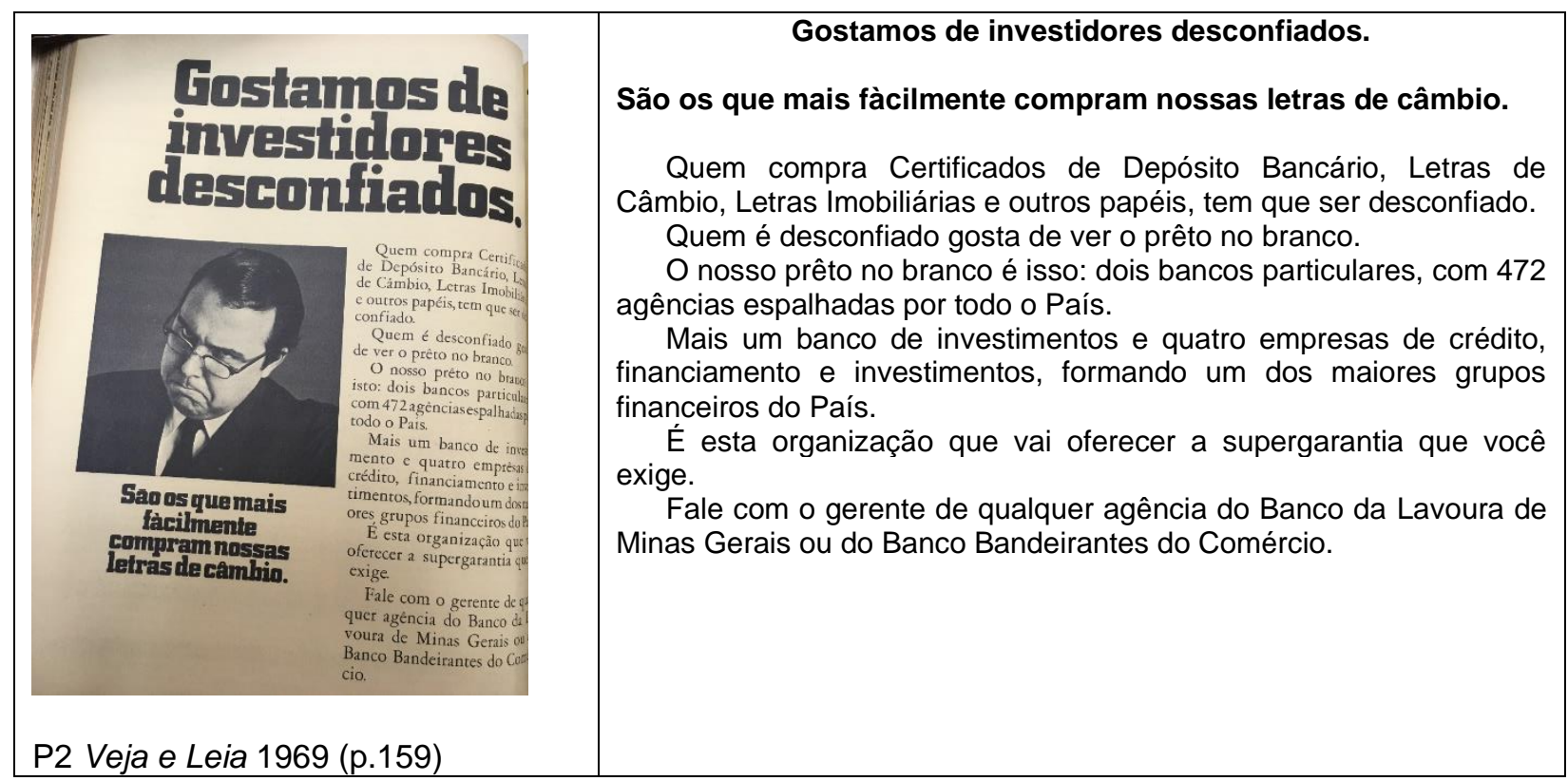

Em relação à função de representação, observamos que, diferentemente da $\mathrm{P} 1$, a representação narrativa acional é não transacional, pois identificamos um participante, mas não o alvo do seu olhar. O destaque, nesse caso, é para a expressão de desconfiado do participante e não o alvo do olhar. Essa expressão parece dizer que o participante não está direcionando o olhar para alguém ou para algum lugar e, sim, ele está com o seu próprio pensamento, provavelmente questionando informações sobre algum produto.

Quanto à função de interação, assim como em P1, observamos o contato de oferta, o participante servindo apenas para apreciação do leitor, não há contato direto do olhar. O plano médio/medium shot marca a média distância social entre o participante e o leitor. O participante aparece de lado para o leitor, demarcando uma perspectiva/atitude de médio distanciamento, e ainda é captado sob um ângulo de igualdade com o leitor.

No que tange à função de composição, observamos o valor da informação ideal $\times$ real invertido, no topo da propaganda em letras grandes e chamativas "Gostamos de investidores desconfiados" a informação real, convidando o leitor/cliente a adquirir as letras de câmbio porque o banco se interessa pelo seu perfil "de desconfiado"; e na parte inferior, informação ideal, "São os que mais fàcilmente [sic] compram nossas letras de câmbio", como o banco é confiável e transparente, o cliente constata que "é esta organização que vai oferecer a supergarantia" que ele exige para comprar o produto, "em qualquer agência do Banco da Lavoura de Minas Gerais". 


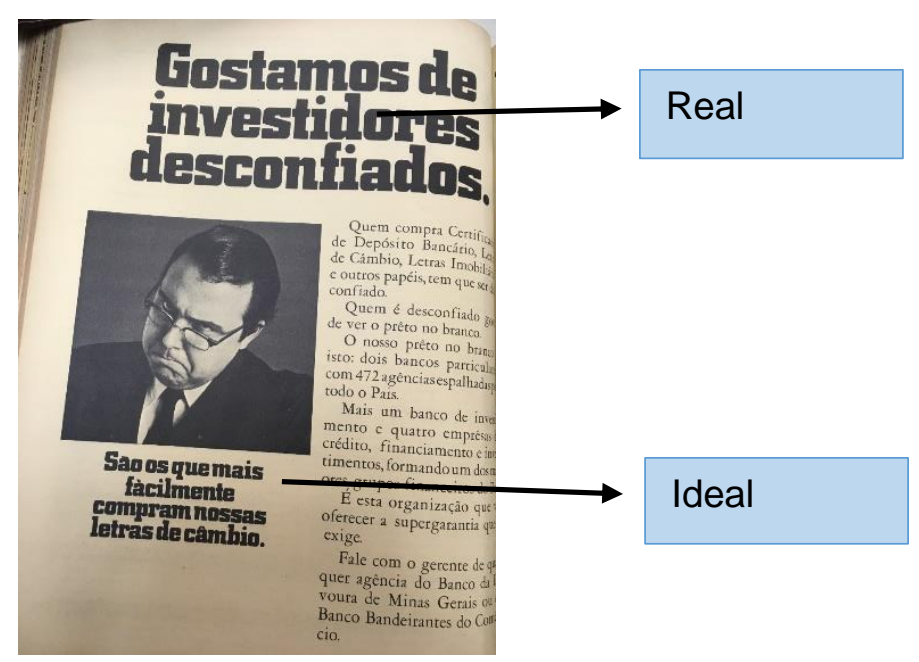

Veja e Leia 1969 (p.159)

Os parágrafos iniciais da propaganda são dirigidos ao leitor de forma genérica "os que", "quem" e "desconfiados", somente no penúltimo parágrafo é dirigido ao embreante "você", levando a uma possibilidade de análise que, à medida que a desconfiança do leitor vai diminuindo, pelas garantias e qualidades confiáveis do banco, vai diminuindo o distanciamento e aumentando a intimidade entre esses atores sociais. Essa possibilidade de análise é reforçada pelo imperativo no último parágrafo "fale com o gerente de qualquer agência do Banco...", "fale" pode significar venha, aproxime-se, converse.

- São os que mais facilmente compram nossas letras de câmbio.

- Quem é desconfiado gosta de ver o prêto no branco.

- É esta organização que vai oferecer a supergarantia que você exige.

- Fale com o gerente de qualquer agência do Banco da Lavoura de Minas Gerais ou do Banco Bandeirantes do Comércio.

Quanto à teoria da valoração, as relações estabelecidas entre anunciante e leitor, o enunciado "gostamos de investidores desconfiados" remete à atitude de afeto do enunciador para com o coenunciador. O adjetivo desconfiado aparece duas vezes vinculado ao verbo gostar. $O$ anunciante gosta de investidores desconfiados porque se garante como digno de confiança e clareza nas relações e o leitor que é desconfiado gosta de ver as coisas às claras e facilmente compra os produtos bancários.

- Quem é desconfiado gosta de ver o prêto no branco. 
- O nosso prêto no branco é isso: dois bancos particulares, com 472 agências espalhadas por todo o País.

- É esta organização que vai oferecer a supergarantia que você exige.

O enunciado "a supergarantia que você exige" remete também a um valor de apreciação positiva do enunciador que conhece seu cliente e, por isso, sabe que ele é "exigente" quanto às garantias a serem oferecidas por uma instituição financeira naquela década marcada por contestações e, consequentemente, pela necessidade de dedicação e atendimento presencial cordial e personalizado aos clientes, gerando pontos para a imagem institucional positiva do Banco da Lavoura.

A P3, propaganda impressa em preto e branco, página inteira simples, foi coletada da revista Exame - salvo restrições mencionadas na descrição das propagandas desta década - direcionada ao público-alvo executivo.

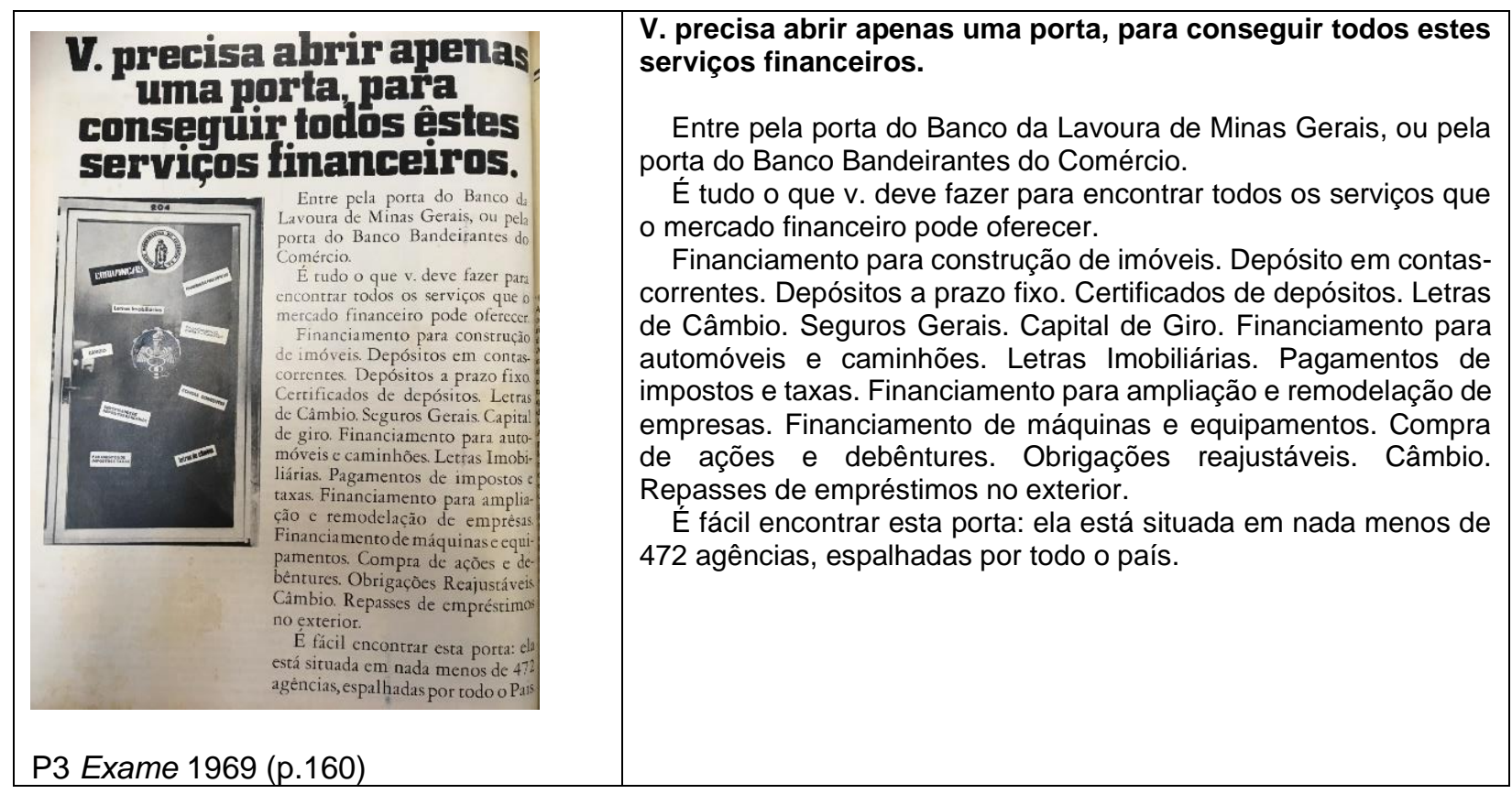

A partir de uma visão geral dessa propaganda, é possível perceber que, assim como na anterior, há mais linguagem verbal que visual. A imagem que ocupa menos de $1 / 4$ da página é de uma porta que gera, pelo menos, duas leituras: tem uma maçaneta de porta de casa e/ou ponto comercial e um número no topo representando um endereço, mas tem também um símbolo circular, no centro da porta, que lembra um segredo de cofre, metaforizando um cofre de banco. As etiquetas pregadas na parte do fora da porta 
são de alguns produtos comercializados pelo Banco da Lavoura, relacionados no texto verbal ao lado. Se admitirmos a possibilidade de porta de cofre, podemos analisar que 0 Banco da Lavoura é um lugar seguro para os seus produtos, merecedor, portanto, da confiança de seus clientes, que podem ter a tranquilidade de ver seus investimentos guardados com segurança.

No que se refere à função de representação, da GDV, de Kress e van Leeuwen (2006), essa propaganda, contrastando com as outras duas dessa década, insere-se na representação conceitual simbólica analítica, posto que traz uma identificação da parte pelo todo, ou seja, a porta representando o Banco da Lavoura. Dentre os processos dessa função, também identificamos o classificatório no conjunto de etiquetas pregadas na porta e, como o conjunto não está acompanhado de legenda para determinar os participantes, é chamado de classificatório implícito.

A imagem se dá por um contato de oferta, como nas duas propagandas anteriores, remete a objeto de contemplação para o leitor e, consequentemente, impessoalidade. No que diz respeito à distância social, apresenta o plano médio/medium shot ou relação de nível apenas social entre o participante e o leitor. No plano da perspectiva/atitude, 0 participante é captado por um ângulo frontal, participante no mesmo nível do leitor, determinando uma relação de poder de igualdade. Todos esses aspectos demarcam a função de interação de análise.

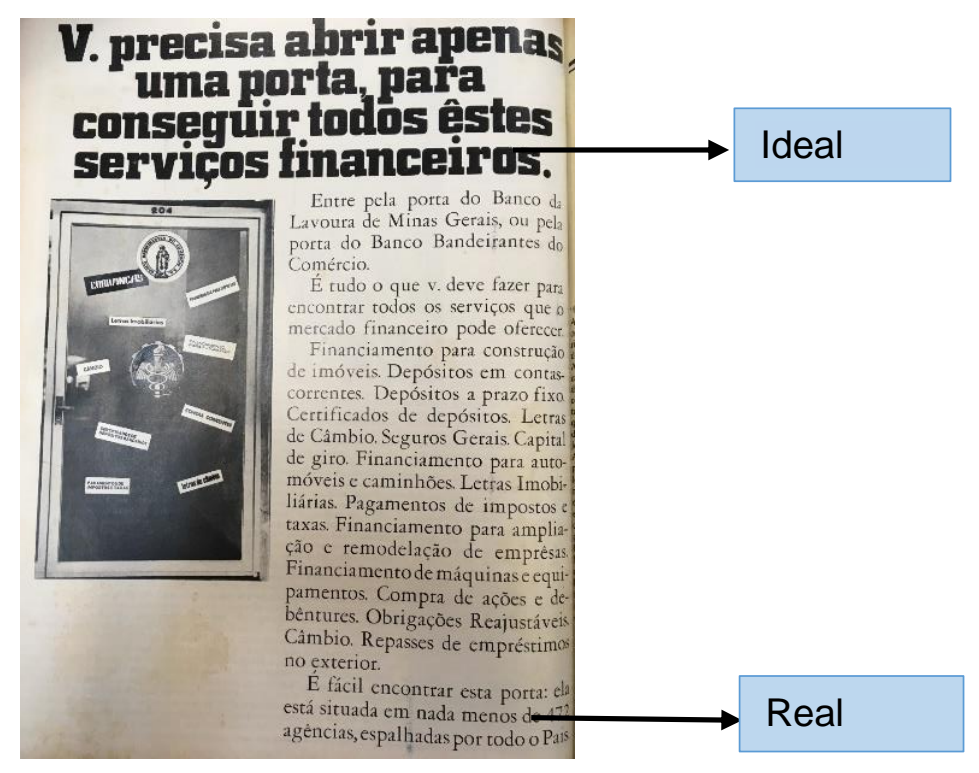

Exame 1969 (p.160) 
Relativamente à função de composição, em P3, o texto multimodal está organizado sob a ótica ideal $\times$ real. A informação do topo (ideal) destaca as possibilidades conquistadas a partir de um simples abrir de porta que é "conseguir todos estes serviços financeiros", enquanto a informação da base da propaganda destaca a facilidade de encontrar a porta "em nada menos de 472 agências, espalhadas por todo o país", conforme enunciados a seguir. A porta, apesar de não ser exageradamente grande no espaço da página, destaca-se bastante, atraindo a atenção do leitor, papel relevante na saliência.

-V. precisa abrir apenas uma porta, para conseguir todos estes serviços financeiros.

- É fácil encontrar esta porta: ela está situada em nada menos de 472 agências espalhadas por todo o país.

O enunciado inicial invoca o leitor com um aconselhamento "v. precisa abrir apenas uma porta" e, na sequência, o convida a entrar pela porta do Banco da Lavoura, o que se repete no terceiro parágrafo "é tudo o que você deve fazer". Nesses exemplos, observa-se que o coenunciador é chamado de você abreviado por "v.", uso comum em diversos textos de antigamente, principalmente em situações de informalidade/intimidade, ou seja, é uma marca de aproximação entre o anunciante e seu leitor.

Encontramos na propaganda a marca "Banco da Lavoura" e expressões como "mercado financeiro", "porta", "472 agências" remetendo ao anunciante; portanto a presença do enunciador não é marcada de forma explícita. Ela é indicada pelo fato de existir um "você" representado pelo coenunciador, que é interpelado "v. precisa abrir", "entre pela porta do Banco", pressupondo a presença de um enunciador, o que Maingueneau (2013) considera como outras marcas de presença do enunciador.

\subsubsection{Década de 1970}

As três propagandas selecionadas na década de 1970 foram recolhidas em exemplares dos anos 1971, 1977 e 1979. O ano de 1971 marca o momento em que o 
Banco da Lavoura mudou de nome para Banco Real e, em função disso, a propaganda da revista Veja, de janeiro desse mesmo ano é assinada pelo Banco da Lavoura e, as propagandas da revista Claudia (outubro de 1979) e da revista Exame (outubro de 1977) são assinadas pela nova marca Banco Real. As propagandas das revistas Veja e Exame são em preto e branco, ilustradas com desenhos representando participantes humanos, e a da Claudia é em cores e tem como participante um extrato bancário fotografado.

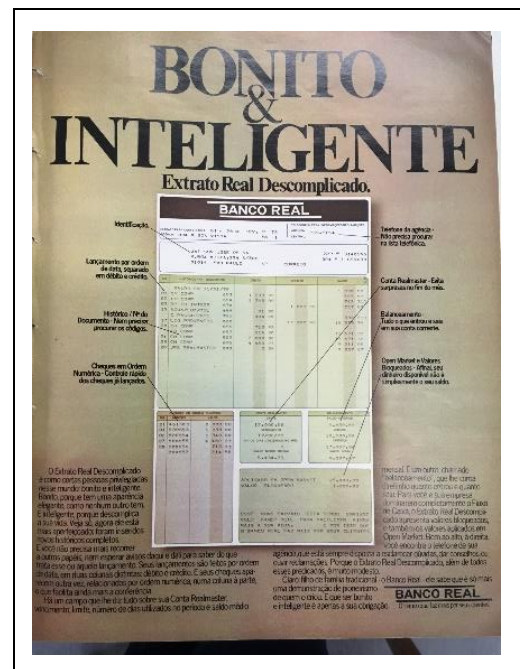

Claudia 1979 (p.161)

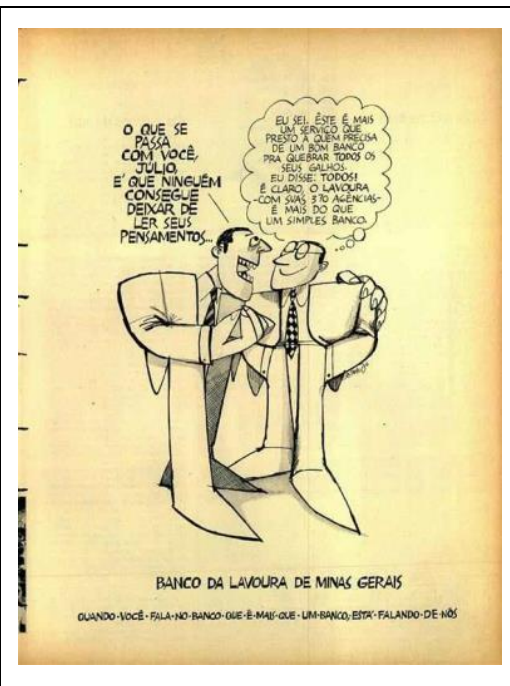

Veja 1971 (p.162)

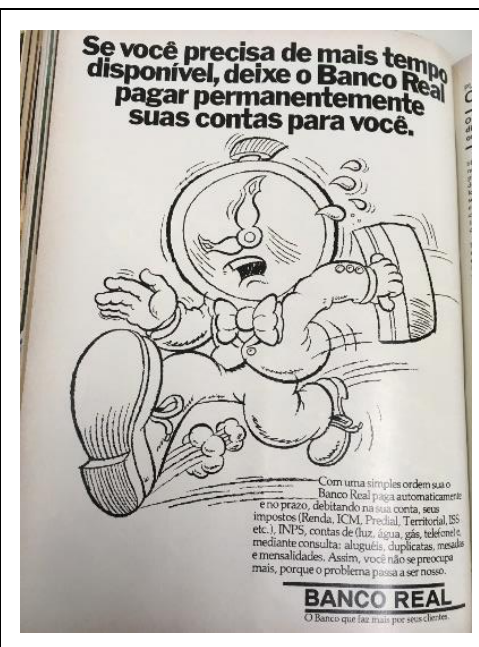

Exame 1977 (p.163)

Figura 27 - Propagandas - anos 1970

\subsubsection{Breve contexto histórico do Brasil na década de 1970}

O período de 1970 a 1979 foi marcado pela terceira vitória do Brasil na Copa do Mundo de Futebol e por um senso de nacionalismo apurado. Após a conquista do tricampeonato (1970), os 90 milhões de brasileiros cantavam unidos "pra frente Brasil, do meu coração", e o país correspondia.

Houve uma grande expansão do setor industrial e automobilístico. Conforme Brandão (1995, p. 95), "os bancos, os transportes e os sistemas de comunicação ganharam em agilidade, alimentados pela maior demanda, decorrente do desenvolvimento industrial". 
“O período chamado 'milagre' estendeu-se de 1969 a 1973, combinando o extraordinário crescimento econômico com taxas relativamente baixas de inflação. [...] A inflação média passou de $18 \%$. Isso parecia de fato um milagre. Só que o fenômeno tinha uma explicação terrena e não podia durar indefinidamente" (FAUSTO, 2006, p. 469), como de fato se provou. Em 1973, ocorreu o choque causado pela elevada alteração no preço do petróleo e, consequentemente, o aumento nas taxas de juros e redução no ritmo da atividade econômica mundial. Em consequência, o Brasil passou a estimular a exportação, iniciando um processo de abertura para a democracia. Com isso, surgia a necessidade de as instituições financeiras se lançarem a outros países.

Para as instituições financeiras, o momento era de acirrada disputa. Algumas desapareciam e as grandes tinham de se fortalecer. O Banco da Lavoura de Minas Gerais era uma das grandes, ocupava, em 1970, a sexta posição entre os 500 maiores bancos particulares do mundo (BRANDÃO, 1995) e, em 1973, tornou-se o Banco Real.

\subsubsection{Análise das propagandas dos anos 1970}

As três propagandas selecionadas da década de 1970 apresentam algumas diferenças, como: duas são ilustradas com desenhos caricaturais representações de participantes humanos e uma traz a imagem de um extrato bancário; duas são impressas em preto e branco, uma em cores; duas possuem uma chamada em destaque no topo da página, uma não possui chamada e resume-se basicamente ao diálogo entre dois participantes. As três têm o logotipo do banco na base da página, diferentemente das peças analisadas dos anos 1960.

A P4 foi publicada na revista Claudia, no final da década de 1970, e veicula a imagem de um extrato bancário da época e detalhes de cada parte do extrato, portanto são os argumentos verbais os elementos de persuasão nessa propaganda. O enunciado 
no topo da página chama a atenção da leitora ${ }^{18}$ da revista feminina, pois traz em destaque duas características almejadas pelas mulheres: beleza e inteligência. Para o reforço linguístico de que tais adjetivos podem estar sendo dirigidos também à mulher leitora da revista, em enunciados mais adiante encontramos:

- O Extrato Real Descomplicado é como certas pessoas privilegiadas nesse mundo.

- É bonito porque tem uma aparência elegante como nenhum outro tem.

- É inteligente porque descomplica a sua vida.

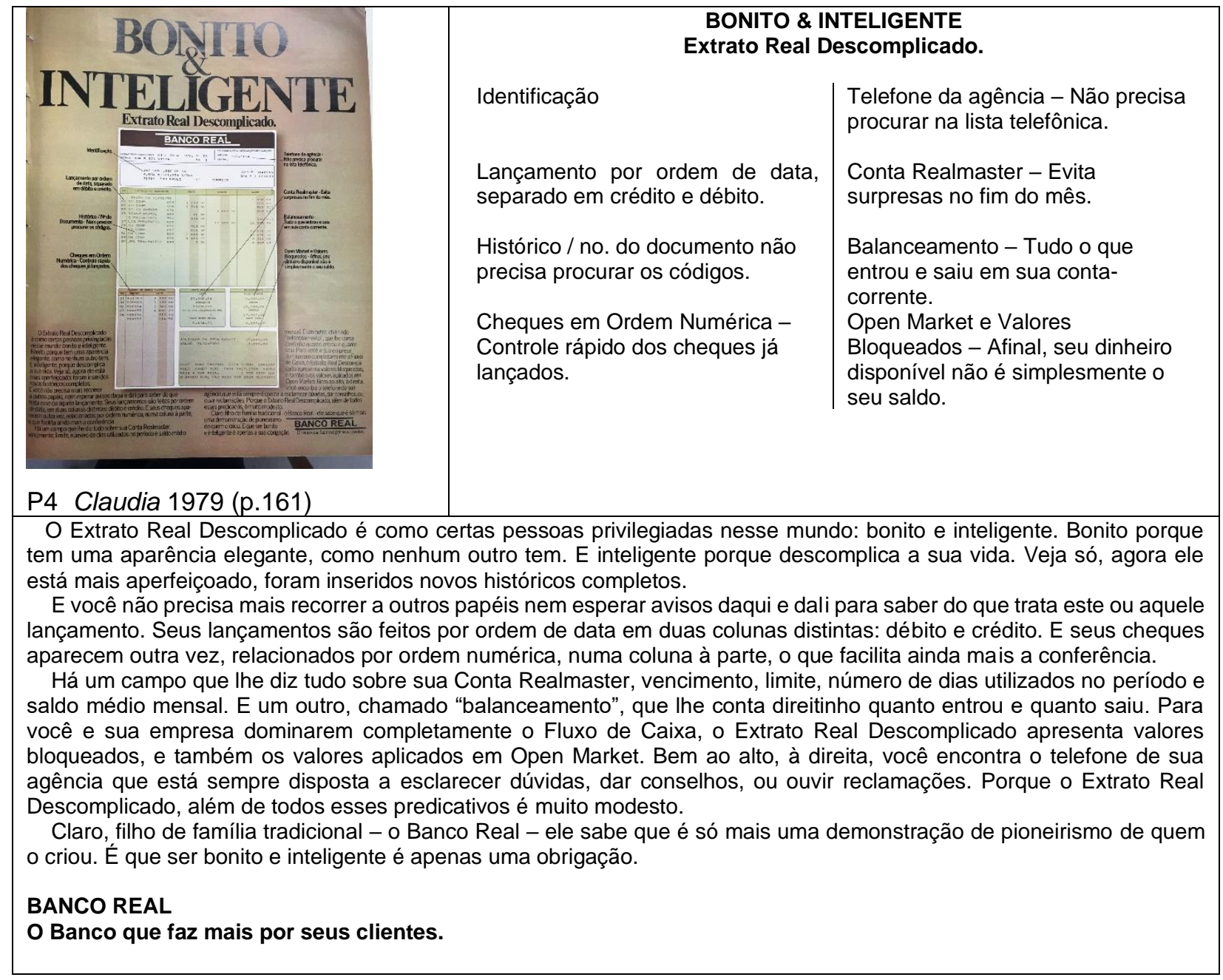

Em relação à função representacional, a propaganda está inserida na representação conceitual analítica, identificada na representação do extrato, ou seja, o extrato personifica as características do banco que:

${ }^{18}$ Apesar de não haver um indicador de que o enunciado se dirige ao público feminino, consideramos que, por se tratar de Claudia (revista feminina), a propaganda foi pensada para se dirigir à leitora da revista. 
- descomplica a sua vida.

- além de todos esses predicativos, é muito modesto.

- ser bonito e inteligente é apenas a sua obrigação.

O participante extrato de conta-corrente recebe atributos que são características importantes a uma instituição financeira que deve prestar serviços para descomplicar a vida do cliente.

No que corresponde à função interacional, observamos o contato de oferta, o participante sendo ofertado para a apreciação do leitor; na distância social, o plano fechado/closep up destaca o extrato e leva a uma percepção de intimidade entre a participante leitora (mulher) e o extrato bancário; na perspectiva/atitude, o ângulo frontal do participante corrobora essa análise de mais intimidade e de igualdade com o públicoalvo; ainda podemos perceber a modalidade naturalista, a cena do extrato de contacorrente sendo explicado em detalhes equivale à realidade, inclusive da mulher que só teve o direito de movimentar a "sua" conta-corrente a partir do final dos anos 1960, ou seja, era recente a autorização recebida do marido para que ela tivesse a própria contacorrente, como já mencionado.

Destacando a função composicional, observamos o valor da informação pelos eixos principal e marginal, o centro da atenção da leitora é o extrato de "sua" contacorrente e ela necessita conhecê-lo detalhadamente para saber que:

- você não precisa mais recorrer a outros papéis nem esperar avisos daqui e dali [...]

- Para você e sua empresa dominarem completamente o Fluxo de Caixa [...]

mais que um extrato bancário, esse documento representa a independência e autonomia da mulher do final dos anos 1970. 


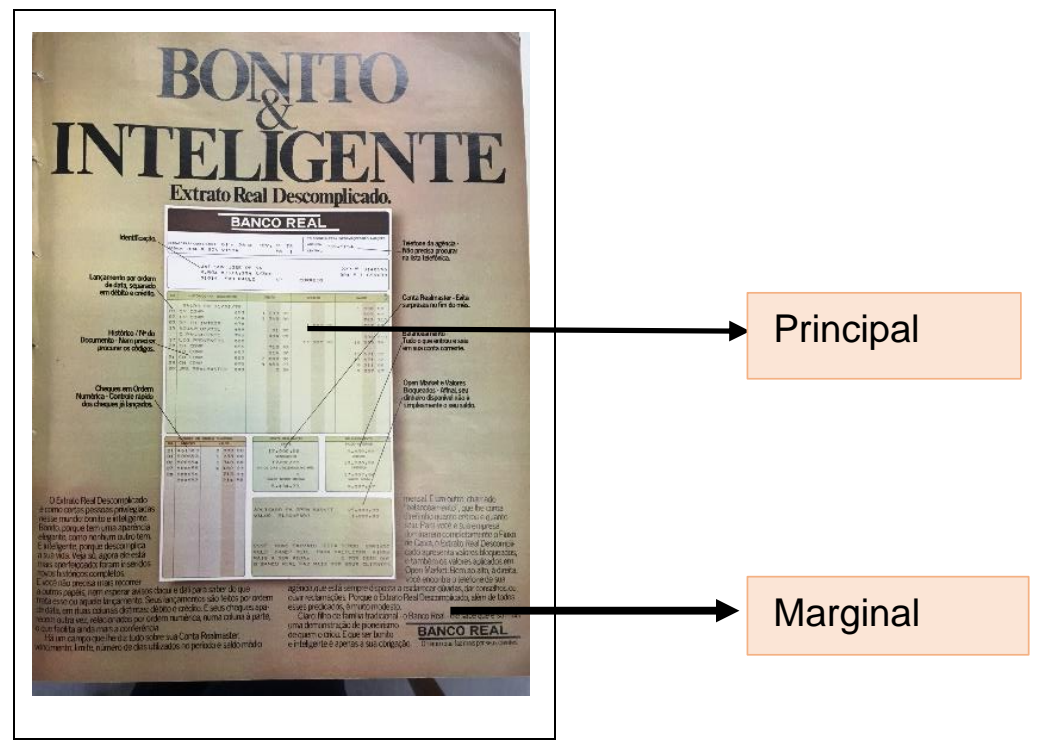

Claudia 1979 (p.161)

A saliência é perceptível pelo tamanho e destaque - valor tonal e diferença em acuidade - do extrato bancário na página multimodal.

$\mathrm{Na}$ cena enunciativa da propaganda da revista Claudia, o enunciador não marca explicitamente sua presença, mas por meio de um "eu" implícito, que se dirige a um "você" tomado como testemunha - "veja só", em um momento de enunciação marcado pelo embreante temporal "agora", além das marcas de tempo dos verbos como "você encontra", "você não precisa", "o que facilita", "ele sabe", "é muito modesto". Trata-se de um enunciado embreado, que, segundo Maingueneau (2013, p. 136), "[constitui] a imensa maioria dos enunciados produzidos. É difícil imaginar o que seria uma conversa que não remetesse ao contexto da enunciação ou que não interpelasse o coenunciador". O enunciador ainda marca sua presença em enunciados como este:

- Claro, filho de família tradicional - o Banco Real - ele sabe que é só mais uma demonstração de pioneirismo de quem o criou.

Já o coenunciador é marcado, além do "você", já mencionado, pelos embreantes "seus" "Ihe", "sua", presentes nos enunciados a seguir:

- E seus cheques aparecem outra vez [...]

- Há um campo que Ihe diz tudo sobre sua Conta Realmaster [...]

• [...] você encontra o telefone de sua agência $[\ldots]$ 
A partir dessas considerações e outras apresentadas no início da análise desta propaganda, podemos observar uma intenção do anunciante de aproximar a mulher leitora da revista - do extrato de conta-corrente - produto do anunciante - a partir dos atributos: "bonito", "inteligente", "elegante", e, com isso, identificar valores de afeto construídos pelo enunciador para uma aproximação com esse público-alvo e, consequentemente, promover sua aceitação e identificação com ele.

Passando à análise da P5, propaganda veiculada na revista Veja, no início da década de 1970, deparamo-nos com a ilustração de um cliente falando com o gerente do Banco da Lavoura, que esboça um sorriso e reflete (pensa) orgulhoso sobre as palavras do cliente. É uma propaganda com pouquíssimo texto, valorizando a representação dos dois homens em uma relação de amizade (a mão do cliente sobre o ombro do gerente).

\begin{tabular}{|c|c|}
\hline 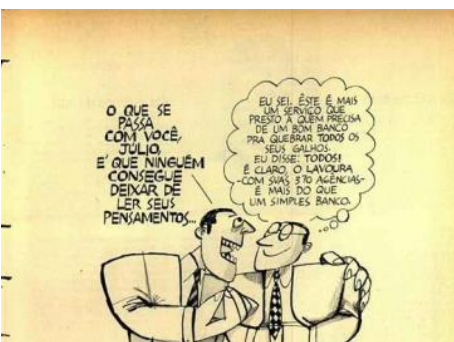 & $\begin{array}{l}\text { O QUE SE PASSA COM VOCÊ, JULIO É QUE NINGUÉM } \\
\text { CONSEGUE DEIXAR DE LER SEUS PENSAMENTOS. } \\
\text { EU SEI ÊSTE É MAIS UM SERVIÇO QUE PRESTO A QUEM } \\
\text { PRECISA DE UM BOM BANCO PRA QUEBRAR TODOS OS } \\
\text { GALHOS. EU DISSE: TODOS! É CLARO O LAVOURA COM SUAS } \\
370 \text { AGÊNCIAS - É MAIS DO QUE UM SIMPLES BANCO. }\end{array}$ \\
\hline 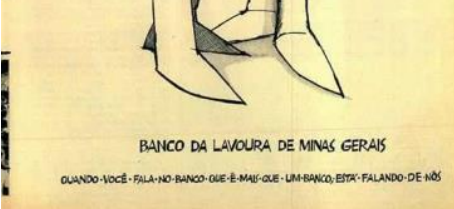 & $\begin{array}{l}\qquad \text { BANCO DA LAVOURA DE MINAS GERAIS } \\
\text { QUANDO-VOCÊ-FALA-NO-BANCO-QUE-É-MAIS-QUE-UM-BANCO; } \\
\text { ESTÁ-FALANDO-DE-NÓS }\end{array}$ \\
\hline P5 $V$ & \\
\hline
\end{tabular}

Essa propaganda retrata dois participantes- um exercendo ação sobre o outro e um vetor (o braço do cliente abraçando o gerente), função representacional, considerada por Kress e van Leuween (2006), narrativa acional transacional. Nota-se ainda, nessa página, o processo mental e o processo verbal, representados pelo balão de fala do cliente e pelo balão de pensamento do gerente. A questão de o cliente falar é esclarecida no enunciado na base da imagem:

- Quando você fala no Banco que é mais que um banco está falando de nós. 
$\mathrm{Na}$ função interacional, o contato é de oferta, a distância social é de plano aberto/long shot - a interação ocorre entre os participantes; no entanto, em relação ao leitor, verificamos que a distância social é marcada pela impessoalidade. O que se repete no posicionamento dos participantes - de lado (ângulo oblíquo) - implicando um distanciamento do leitor no que se refere a perspectiva/atitude.

Por fim, a função composicional, em que o valor da informação pode ser percebido na oposição centro/margem, os dois participantes posicionados no centro da propaganda representam a informação principal, contrapondo-se aos elementos distribuídos nas margens superior e inferior, que representam a informação complementar/marginal, como podemos notar no destaque a seguir.

Processo verbal

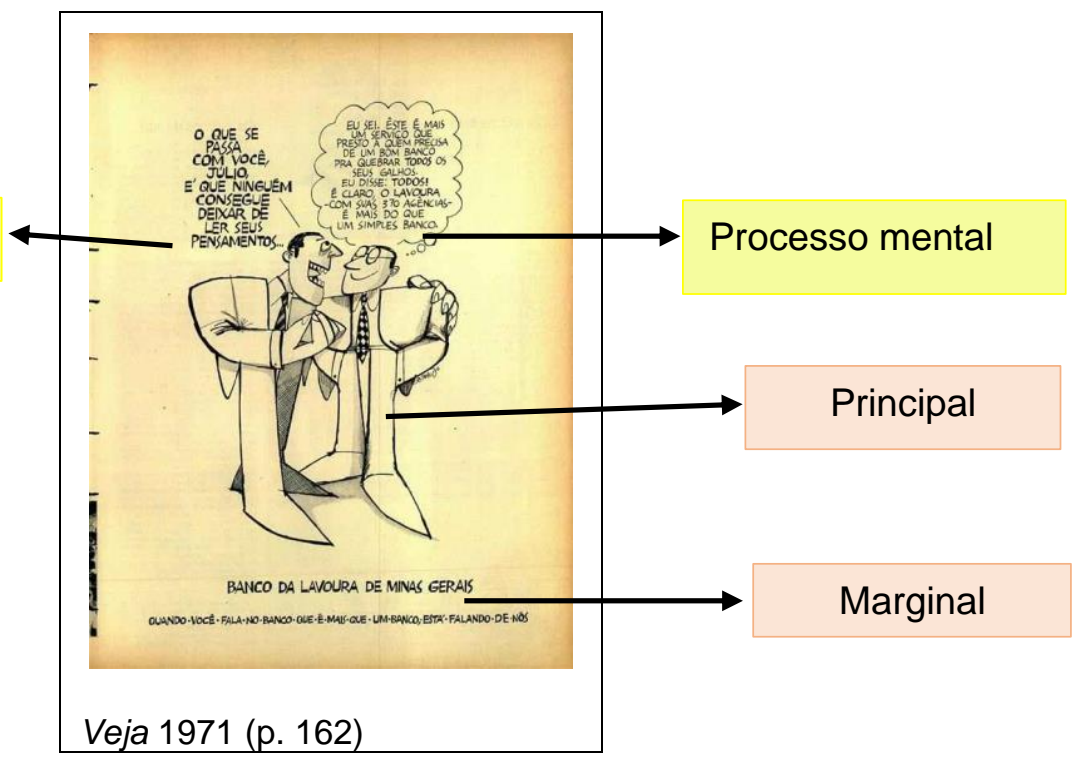

O coenunciador é representado pelo cliente (participante da esquerda) que é marcado no texto pelos pronomes "seus" e "você" (no pensamento do gerente) e "você", já o enunciador é representado pelo gerente e é marcado pelos pronomes "eu" e "nós", o verbo no presente do indicativo em primeira pessoa do singular "presto" ratifica o enunciador.

Podemos apreender, a partir da cena da P5, posições de valores do cliente - o leitor - e do gerente - o anunciante. O cliente demonstra de forma implícita ao gerente atitude de afeto, imbuída nos adjetivos transparente e confiável, a quem "ninguém consegue deixar de ler seus pensamentos"; e o gerente reforça o valor do banco a quem representa com outros valores de afeto: "um bom banco para quebrar todos os galhos" e 
"mais que um simples banco". Tanto na fala do cliente como no pensamento do gerente o banco é confiável, transparente, capaz e competente, atributos positivos para a imagem institucional construída na propaganda. E a instituição financeira, propriamente dita, na base da propaganda, assume seu posto de enunciador e, revestido da atitude de apreciação positiva, reporta-se ao coenunciador:

- Quando você fala no Banco que é mais que um banco: está falando de nós.

Nesse enunciado, "nós" não inclui o coenunciador, equivalendo, na verdade, a um "eu" restrito ao enunciador - Banco da Lavoura. Conforme Maingueneau (2013, p. 152): “No 'nós', a predominância do 'eu' é muito forte, a ponto de, em certas condições, este plural poder passar pelo singular", parecendo-nos ser este o caso, pois o Banco da Lavoura se promove como o "banco que é mais que um banco", o que se justifica pela sexta posição que ocupava entre os 500 maiores bancos particulares do mundo naquela década de acirrada disputa. Sem dúvida, o banco tinha de si uma imagem positiva de "mais que um banco", mas mesmo assim tinha de se fortalecer para não desaparecer, como era a tendência da época.

A P6, terceira propaganda dos anos 1970, foi veiculada na revista Exame, assim como a anterior, é uma ilustração de uma pessoa de terno, gravata borboleta e maleta de executivo, caricatura de um homem com cabeça em forma de relógio ou de um relógio com a base em forma de corpo de homem. Representa a pressa, gotas de suor no rosto e fumacinha nos pés indicam uma pessoa com muita pressa. Remete à metáfora "correr contra o relógio". Essa luta contra o tempo justifica-se pelo fato de os executivos estarem inseridos em uma época de grande expansão do setor industrial e automobilístico e, consequentemente, em momento de acirrada disputa pelo mercado. 


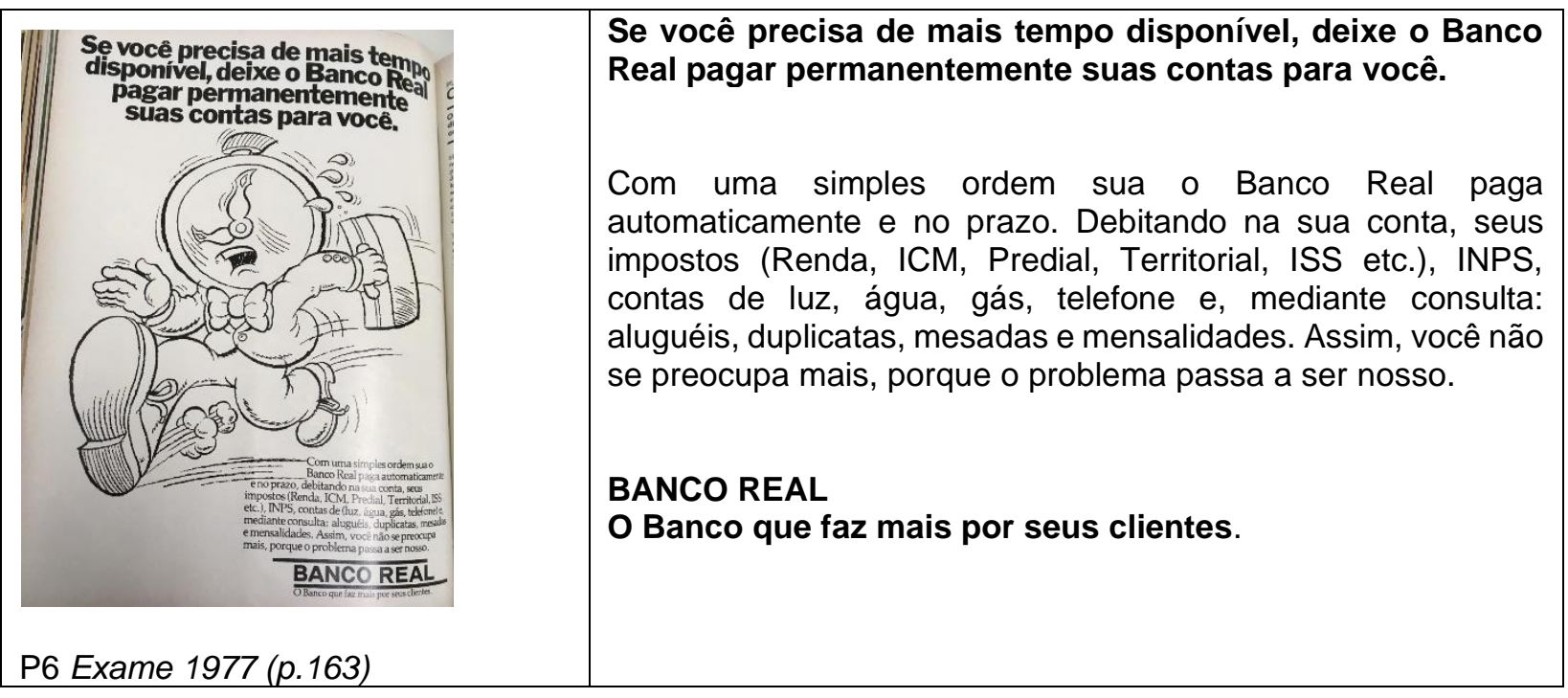

Na propaganda, há apenas um participante e um vetor, que pode ser considerado o próprio corpo do participante em movimento, como se estivesse correndo, mas não se observa contato visual na função da representação, trata-se de uma representação narrativa com processo de ação não transacional, não se observa a ação direcionada a algo ou a alguém.

Em relação à função de interação, em termos de contato, temos oferta, o participante encontra-se à mercê do olhar do leitor. A distância social entre o participante e o leitor é de médio plano/medium shot, ou seja, uma relação do tipo social entre o anunciante e seu público-alvo. A perspectiva/atitude é evidenciada pelo ângulo oblíquo, o corpo do participante está de lado, demarcando médio distanciamento; e, quanto à modalidade, observa-se a sensorial, pois a imagem provoca um efeito que vai além da realidade - um homem relógio.

Dando sequência à análise visual a partir das categorias da GDV, no tocante à representação composicional, o enunciado da parte superior da imagem contém a informação real, o cliente está na correria e precisa de mais tempo disponível.

- Se você precisa de mais tempo disponível, deixe o Banco Real pagar permanentemente suas contas para você. 
E, na parte inferior, encontra-se a informação ideal: as contas que o banco poderá pagar para o cliente, deixando-o despreocupado porque o problema passará a ser do banco.

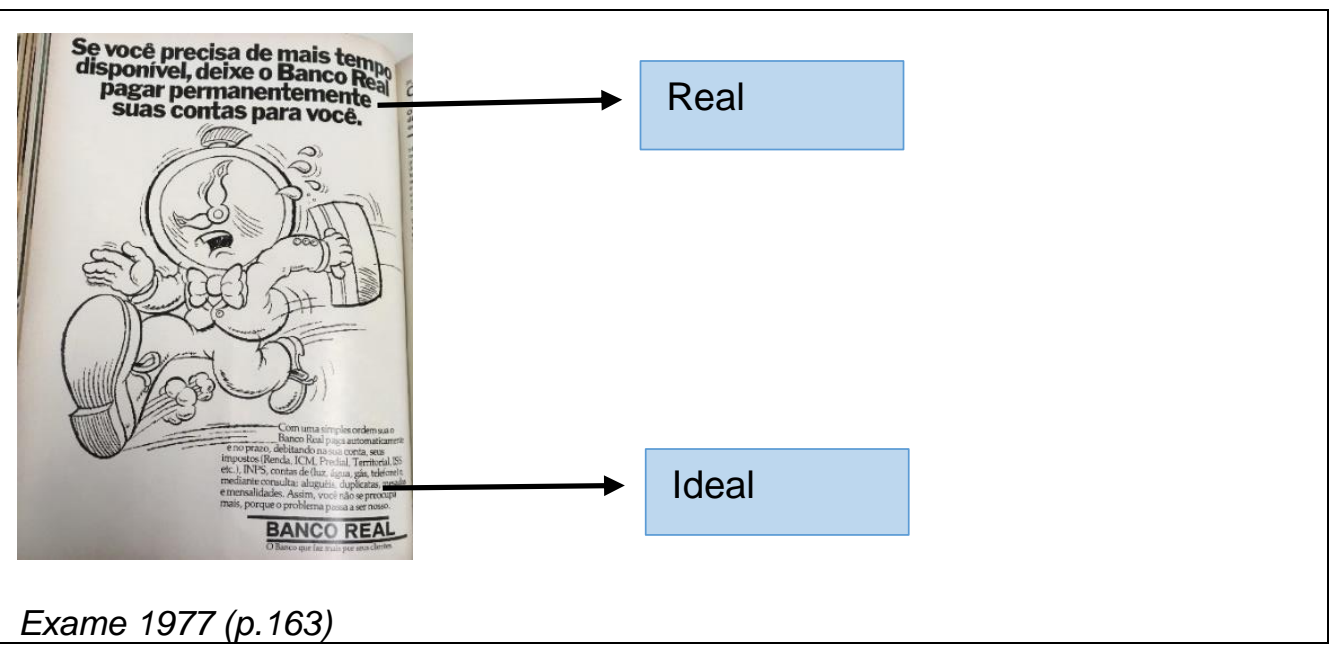

A saliência se manifesta pelo tamanho do participante e seu volume na página. Tanto na P5 como na P6, observamos que a linguagem verbal perdeu espaço e a visual ganhou nas propagandas dessa década.

Enunciador e coenunciador têm a presença marcada, destacando-se o leitor de forma mais representativa que o anunciante. Há um maior número de marcas da presença do leitor: pronomes "você", "sua", "seus" e verbo no imperativo "deixe". Já as de presença do anunciante são em menor quantidade, mas são acompanhadas de ações relevantes como: "o Banco Real" que "paga permanentemente" e "automaticamente" as contas e que "faz mais por seus clientes"; o pronome "nosso" aparece para assumir o problema do cliente.

- Assim você não se preocupa mais, porque o problema passa a ser nosso.

Em "você não se preocupa mais" evidenciamos um valor de afeto do anunciante para com o leitor que poderá ficar "despreocupado", pois o anunciante pagará suas contas.

No enunciado que inicia o primeiro parágrafo da propaganda, há uma atitude de julgamento em:

- Com uma simples ordem sua o Banco Real paga automaticamente e no prazo. 
O leitor é instituído de competência para assumir o comportamento de ordenar e a instituição Banco Real de atender à ordem do leitor e efetuar o pagamento automaticamente e no prazo.

Outro exemplo de valor atitudinal de apreciação positiva é o slogan "O Banco que faz mais por seus clientes", novamente é o enunciador se autopromovendo como eficaz, criativo, valioso, ampliando sua imagem positiva junto ao público-alvo.

\subsubsection{Década de 1980}

As propagandas a seguir circularam nas revistas Claudia, em 1980, Veja, em 1981, e Exame, em 1982. A seleção desses três exemplares foi feita pela semelhança visual, ou seja, todas trazem uma chamada: Estratégia Real, Receitas Real e Apoio Real. As da revista Claudia e Exame ainda têm como pontos comuns o fato de serem compostas por desenhos ilustrativos de cenas do cotidiano e as chamadas seguidas de dois pontos.

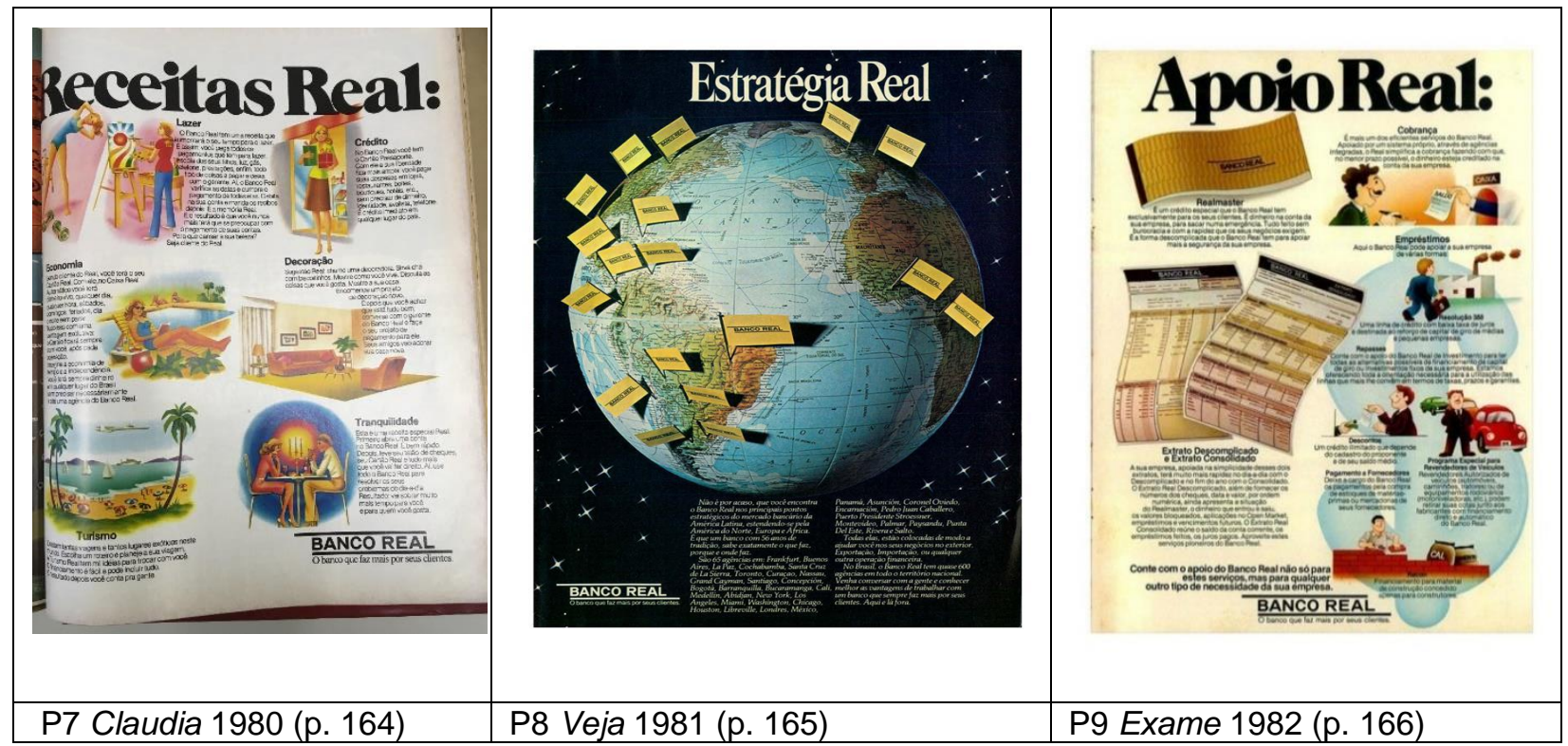

Figura 28 - Propagandas - anos 1980 
As chamadas das três propagandas da década de 1980 remetem a alguns significados figurativos ou metafóricos. A seleção do léxico "Real", nos três contextos, remete ao significado real de "realidade", "que tem existência verdadeira", ainda "aquilo que existe", ou seja, a "estratégia", o "apoio", as "receitas" ou ainda ao significado Real de "Banco Real", instituição financeira que oferece ao público geral: estratégia, oferece ao público feminino "receitas" (conselhos, sugestões) e oferece ao público executivo apoio (sustentação, amparo, ajuda).

\subsubsection{Breve contexto histórico do Brasil na década de 1980: uma década promissora para as instituições financeiras}

A década de 1980 é marcada pelo processo de abertura democrática, iniciado pelo governo anterior e mantido pelo posterior, de João Baptista Figueiredo. Fausto (2006, p. 485) esclarece que "o período de Figueiredo combinou dois traços que muita gente considerava de convivência impossível: a ampliação da abertura e o aprofundamento da crise econômica". Tempos de anistia, de volta dos presos políticos ao país, de criação de novos partidos políticos, de extinção da censura aos meios de comunicação. Novos tempos aqueles.

A economia, no entanto, não apresentava horizontes tão otimistas, o Brasil detinha uma dívida externa crescente, a inflação voltara a subir, ocorrera um grande desaquecimento das atividades industriais. O país teve que apostar no Proálcool, programa que criou o etanol como opção de combustível automotor, e a gasolina passou a ser substituída pelo álcool obtido a partir da cana-de-açúcar.

Para o sistema financeiro, o período era de consolidação, ou seja, diminuíram-se as incorporações estatizantes e os conglomerados financeiros passaram a ser fortes e sólidos. O desafio daquela década para as instituições financeiras era consolidar seus patrimônios e ampliar seus negócios dentro da realidade econômica vigente.

O povo brasileiro lutava continuamente contra a inflação. Segundo Brandão (1995, p. 125): 
A palavra aplicação fazia parte da linguagem corriqueira. Cada cidadão tornouse um minieconomista, pensando dia e noite, no seu salário corroído a cada minuto. Era preciso encontrar formas de se proteger o dinheiro da desvalorização. Recorrer aos bancos não era mais um privilégio de capitalistas, tornara-se necessidade para qualquer pessoa que possuísse um capital mínimo e desejasse preservá-lo [...].

A crise econômica acabou representando para as instituições financeiras um período de evolução, as agências ficaram superlotadas, exigindo remodelação para ganhar mais espaço. Houve necessidade de revisão de suas rotinas de trabalho, de atendimento, de prestação de novos serviços e, consequentemente, de uma nova estruturação, aliada a recursos oferecidos pela informática, que avançava rumo à modernização.

Entre 1983 e 1984, as comunicações por satélite foram introduzidas no Brasil e com elas mais possibilidades e recursos para as instituições financeiras. Um diretor do Banco Itaú sintetizou aquela época com a seguinte frase: "Quando acordamos, estávamos em outro mundo, moderno. Penetrávamos no banco do futuro" (BRANDÃO, 1995, p. 126).

Década de paradoxos a de 1980, nos anos iniciais, "abertura de caminhos, relações pessoais, busca de clientes um a um, dentro de um sistema tradicional, lento, onde os anos se passavam sem grandes modificações. Depois, a agitação das fusões, e incorporações, o crescimento" (BRANDÃO, 1995, p. 126), ou seja, a automatização dos serviços, a informatização e as descobertas de inovações.

A evolução tecnológica no sistema bancário trouxe alterações para as relações com o cliente. Segundo o autor (1995, p. 129), "A conquista do cliente não se faz mais através da relação pessoal e, ao mesmo tempo que há distância, há aproximação". Continua ainda o escritor, "o cliente vem atraído pelo marketing, pelos serviços oferecidos, pelas vantagens. Se a relação pessoal é menos intensa, há meios de fazer esse cliente sentir-se privilegiado".

Nesse processo, as instituições financeiras passam a oferecer aos seus clientes comodidade, segurança, rapidez e conforto. $O$ futuro caminha para a realidade de usar 0 banco de dentro de casa ou do escritório. Algumas instituições implantaram seus próprios caixas eletrônicos, outras optaram pelos "bancos 24 horas" compartilhados; enfim, o 
dinheiro no bolso passou a ser substituído pelos cartões de débito e de crédito e a relação cliente/banco ganhou uma nova configuração.

\subsubsection{Anos 1980: tempos de aberturas e de planos econômicos}

O ano de 1985 representou um marco importante na história da humanidade: Mikhail Gorbatchov abriu as portas da União Soviética para o mundo e, com isso, a glasnost (abertura) virou a palavra de ordem. Esse fato gerou impactos relevantes no final dessa década.

Em 1986, o Brasil lança o Plano Cruzado para tentar estancar a inflação, os preços e salários são congelados, ocorre a desindexação da economia, redução das taxas de juros e, consequentemente, da inflação. A sociedade brasileira ficou chocada, assim como as instituições financeiras, que tiveram de reconsiderar suas estratégias e revisar seu relacionamento com os clientes.

Brandão (1995, p. 142) sintetiza que "os anos 1980 foram de crise. Dívida externa, altas taxas de inflação, alta de juros, problemas estruturais da economia brasileira provocaram a desaceleração do crescimento, interrompido apenas durante os oito meses de duração do Plano Cruzado".

Outro plano econômico foi instituído em 1989 - o Plano Verão - e com ele a nova moeda, cruzado novo, gerando nova desvalorização do dinheiro brasileiro. No mesmo ano, ocorre a queda do Muro de Berlim e, consequentemente, mudanças na configuração do Leste Europeu.

As instituições financeiras buscaram se adaptar a todas essas transformações reestruturando-se continuamente com o objetivo de manter e conquistar clientes, investindo em seu relacionamento com eles. $O$ que poderemos constatar pelas análises que faremos, a seguir, das propagandas do Banco Real. 


\subsubsection{Análise das propagandas dos anos 1980}

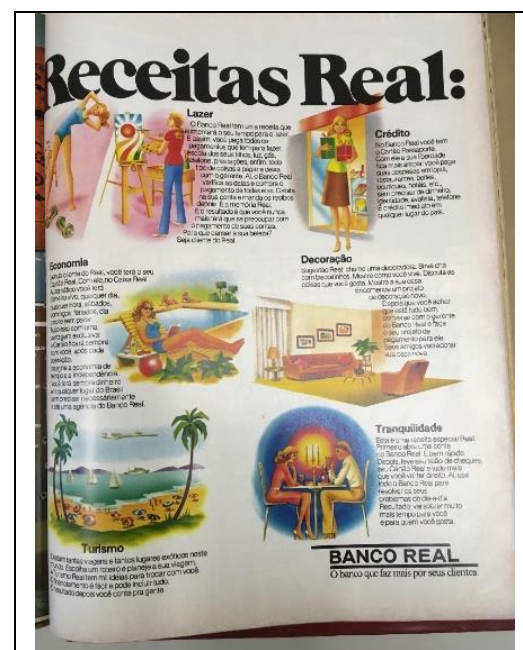

P7 Claudia 1980 (p.164)

Receitas Real:

\section{Lazer}

O Banco Real tem uma receita que aumentará o seu tempo para o lazer. É assim: você pega todos os pagamentos que tem para fazer: escola de seus filhos, luz, gás, telefone, prestações, enfim todo tipo de coisas a pagar e deixa com o gerente. Aí, o Banco Real verifica as datas e cumpre o pagamento de todas elas. Debita na sua conta e manda os recibos depois. É a memória Real. E o resultado é que você nunca mais terá que se preocupar com o pagamento de suas contas. Para que cansar a sua beleza? Seja cliente do Real.

\section{Crédito}

No Banco Real você tem o Cartão Passaport. Com ele a sua liberdade fica mais ampla: você paga suas despesas em lojas, restaurantes, boates, boutiques, hotéis etc. sem precisar de dinheiro, identidade, avalista, telefone. É crédito imediato em qualquer lugar do país.

\section{Economia}

Sendo cliente do Real, você terá seu Cartão Real. Com ele, no Caixa Real Automático você terá dinheiro vivo, qualquer dia, qualquer hora, sábados, domingos, feriados, dia e noite sem parar. Tudo isso com uma vantagem exclusiva: o cartão ficará sempre com você, após cada operação. Imagine a economia de tempo e a independência. Você terá sempre dinheiro em qualquer lugar do Brasil sem precisar necessariamente ir até uma agência do Banco Real.

\section{Decoração}

Sugestão Real: chame uma decoradora. Sirva chá com biscoitinhos. Mostre como você vive. Discuta as coisas que você gosta. Mostre a sua casa. Encomende um projeto de decoração novo. Depois que você achar que está tudo bem, converse com o gerente do Banco Real e faça o seu projeto de pagamento para ele. Seus amigos vão adorar sua casa nova.

\section{Turismo}

Existem tantas viagens e tantos lugares exóticos neste mundo. Escolha um roteiro e planeje a sua viagem. $\mathrm{O}$ Turismo Real tem mil idéias para trocar com você. O financiamento é fácil e pode incluir tudo. O resultado depois você conta pra gente.

Tranquilidade

Essa é uma receita essencial Real. Primeiro abra uma conta no Banco Real. É bem rápido. Depois, leve seu talão de cheques, seu Cartão Real e tudo mais que você vai ter direito. Aí use todo o Banco Real para resolver os seus problemas do dia-a-dia. Resultado: vai sobrar muito mais tempo para você e para quem você gosta.

\section{BANCO REAL}

O banco que faz mais por seus clientes

\section{A P7 tem uma chamada "Receitas Real" seguida de dois pontos. Essa pontuação} indica que serão enumerados alguns itens, como podemos constatar na relação de benefícios que são "receitados" ou sugeridos para a mulher nos tópicos: lazer, crédito, economia, decoração, turismo e tranquilidade. Ligados a esses itens, visualizamos desenhos de clientes (mulheres), em diversas situações do dia a dia, distribuídos por toda a página multimodal. A propaganda assemelha-se a uma receita, descrevendo passo a passo como fazer uma nova decoração, como indicado a seguir: 
- Chame uma decoradora. Sirva chá com biscoitinhos. Mostre como você [...]. Discuta as coisas

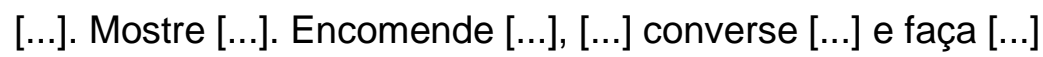

- Seus amigos vão adorar sua casa nova.

Essa descrição lembra também uma "conversa entre amigas", que é reforçada por marcadores e expressões conversacionais espalhados pelo texto, como: "É assim: você pega", "enfim todo tipo de coisas a pagar", "Aí, o Banco Real", "você conta pra gente", "Aí, use todo o Banco Real", remetendo a uma relação de intimidade/aproximação.

No que diz respeito à função de representação das imagens na propaganda em questão, podemos identificá-la como conceitual por processo classificatório, em que as situações do dia a dia são organizadas com o objetivo de demonstrar semelhanças entre elas, ou seja, "aumentar o tempo de lazer" ou "fazer sobrar mais tempo" para a mulher usufruir com a pessoa de quem ela "gosta" e "nunca mais ter que se preocupar com pagamentos de suas contas". Esse processo classificatório ocorre de forma explícita, pois cada cena é legendada indicando o que é tratado: "lazer", "crédito" para despesas diversas, "economia", "decoração", "turismo" e "tranquilidade".

Quanto à função de interação entre o participante e o leitor, há cenas sem a participante simbolizando a mulher, como a do turismo e da decoração; há cenas em que a participante está de costas ou de lado para o leitor e outra, ainda, em que a participante, apesar de estar de frente, não parece buscar nenhum contato visual com o leitor nem com ninguém. As cenas, por elas mesmas, parecem estar ali em um contato de oferta, somente para serem contempladas pelo leitor.

$\mathrm{Na}$ função de composição, quanto ao valor de informação, observa-se a chamada no topo da página (ideal) e a logomarca do banco na base da página (real):

- Receitas Real:

- Banco Real - o banco que faz mais por seus clientes. 


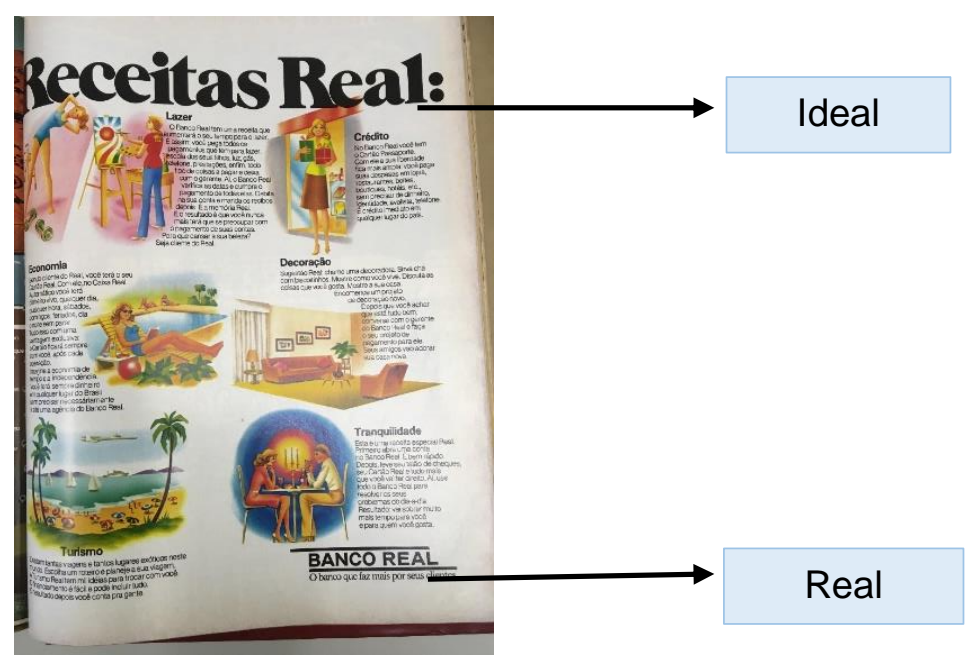

Claudia 1980 (p.164)

A saliência recai sobre o título "Receitas Real", chamando a atenção da leitora para os argumentos verbais e visuais que serão enumerados.

A linguagem verbal utilizada em P7 revela-se significativa em:

- Para que cansar a sua beleza?

- Com ele a sua liberdade fica mais ampla.

- O resultado depois você conta pra gente.

Tais enunciados não aconselham a mulher a descansar pelo "cansaço", mas, sim, a descansar "a sua beleza". Sugere que a mulher deve ampliar a sua "liberdade" e não seus horizontes ou conquistas. Sugere também que a mulher deixe todos os seus pagamentos e problemas para o Banco Real resolver e depois contar o resultado "pra gente" do Real. A seleção lexical "cansar a sua beleza", "você pega os seus pagamentos", assim como a escolha das situações do dia a dia da mulher - lazer, decoração, turismo, tranquilidade - encaminham para uma cena enunciativa de busca de aproximação/intimidade com esse público-alvo - a mulher.

Embreantes (dêiticos) de pessoa - enunciador e coenunciador, de tempo e de espaço encontram-se bastante evidentes na cena enunciativa. O enunciador evidenciase por: "O Banco Real tem", "O Banco Real verifica”, "Com ele a sua”, "conta pra gente". A expressão "a gente" apresenta uma generalização da qual se exclui o coenunciador, 
sendo assumida somente pelo enunciador, que pode estar representando "as amigas do Banco Real que querem saber o resultado" da viagem realizada por ela com os benefícios do financiamento Turismo Real. O coenunciador é marcado por "você", "seu", "sua", "seus", "suas"; o tempo presente por "converse", "discuta", "abra"; e o espaço "aqui" por "qualquer lugar do país", "qualquer lugar do Brasil".

Os valores atitudinais de afeto, como "para você e para quem você gosta" e "seus amigos vão adorar sua casa nova" e ainda "essa é uma receita essencial Real", ou seja, o banco conhece seu público-alvo, sabe o que é importante e fundamental para ele e "receita" tudo de que ele necessita, essa atitude promove aproximação entre o anunciante - banco e a seleta leitora dessa revista feminina.

Chegamos à análise da P8, segunda peça publicitária selecionada da década de 1980 e, dadas as peculiaridades da imagem multimodal, destacaremos algumas categorias da função de representação e da função de composição para o procedimento de análise, não nos ateremos à função de interação.

$\mathrm{Na}$ função de representação, abordamos aquelas categorias em que os atributos, as características e a identidade permitem identificar representações conceituais, que, por sua vez, ocorrem por processos classificatórios, analíticos ou simbólicos. 


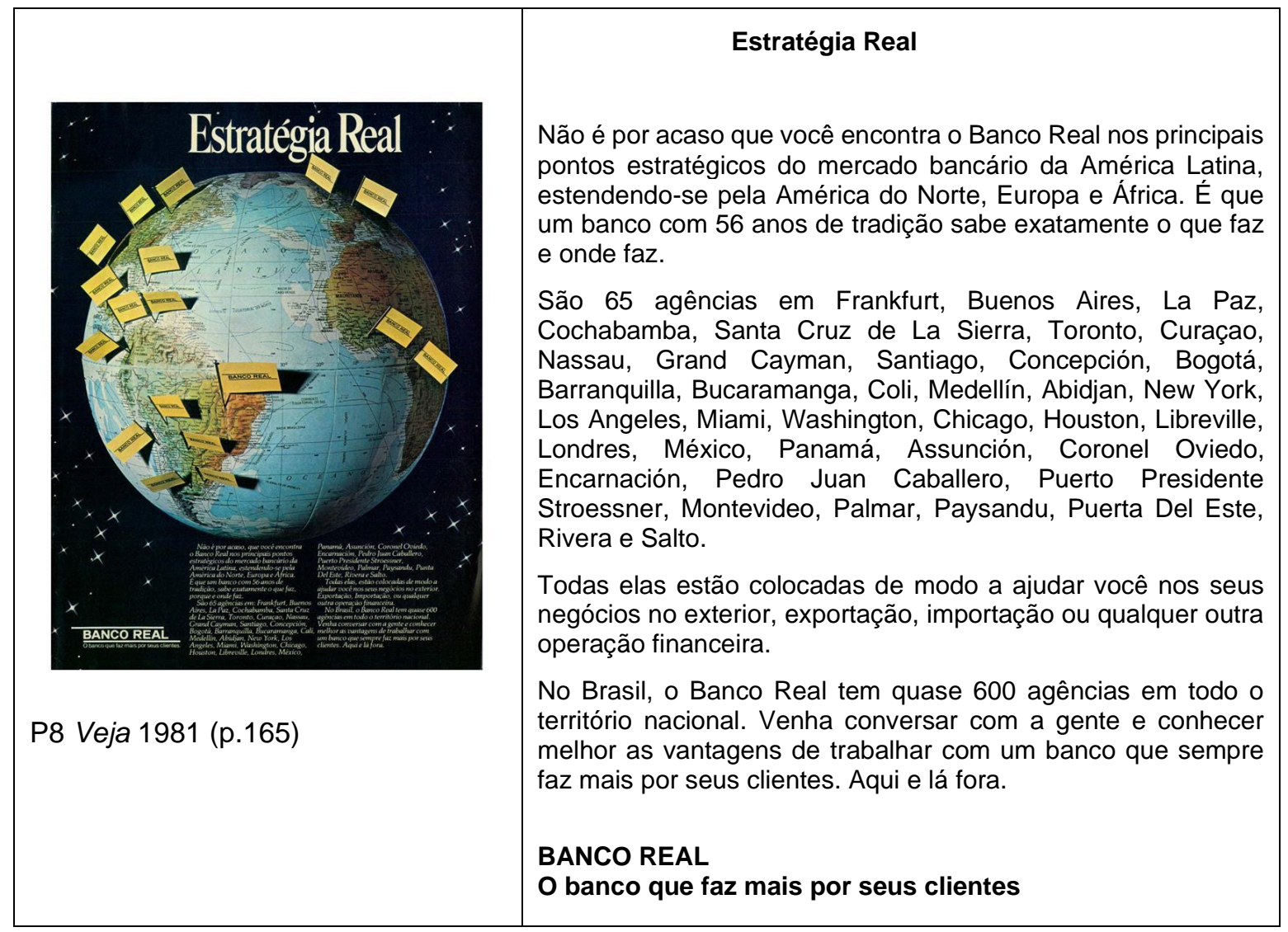

Quanto aos processos classificatórios: participantes organizados de forma simétrica, como as bandeirinhas amarelas, presentes na propaganda da revista Veja P8, indicando a localização das inúmeras agências do Banco Real em todo o globo terrestre. Essa classificação está representada na propaganda de forma implícita, pois não há indicação específica, o leitor é que deve inferir que se referem a agências do Banco Real.

Os processos analíticos, quanto à escolha de representar determinados elementos na imagem com foco em suas partes ou seu todo, refletem os objetivos de quem constrói o texto de forma a produzir determinados efeitos de sentido no público-alvo (NASCIMENTO; BEZERRA; HEBERLE, 2011). Na P8, observamos que o anunciante selecionou um globo terrestre para representar o planeta Terra e a abrangência dos pontos de atendimento do Banco Real, como reforçado no texto abaixo:

- Não é por acaso que você encontra o Banco Real nos principais pontos estratégicos do mercado bancário da América Latina, América do Norte, Europa e África. 
- São 65 agências em Frankfurt, Buenos Aires, La Paz, Cochabamba, Santa Cruz de La Sierra, Toronto, Curaçao, Nassau, Grand Cayman, Santiago, Concepción, Bogotá, Barranquilla, Bucaramanga, Coli, Medellín, Abidjan, New York, Los Angeles, Miami, Washington, Chicago, Houston, Libreville, Londres, México, Panamá, Asunción, Coronel Oviedo, Encarnación, Pedro Juan Caballero, Puerto Presidente Stroessner, Montevideo, Palmar, Paysandu, Puerta Del Este, Rivera e Salto.

Os processos simbólicos relatam o que o participante é/ou significa. Esses processos podem ser divididos em atributivos e sugestivos. Nos atributivos, o participante é destacado por meio de seu posicionamento dentro da imagem, tamanho exagerado, iluminação, nível de detalhamento, foco, tonalidade e/ou intensidade de cor. Em P8, observamos o participante - o globo terrestre - em formato exagerado em relação ao tamanho da propaganda; iluminação, foco e detalhamento bastante evidenciados no participante e intensidade de cor, indicando destaque intencional, o lado em que há maior número de bandeirinhas, ou seja, de agências do Banco Real, a iluminação é mais intensa. O texto, alocado abaixo do globo e que contém a mensagem que o anunciante deseja efetivamente transmitir, acaba se tornando menos valorizado, aparenta menor importância.

A função de composição trata da "organização dos elementos representados na imagem" (NASCIMENTO, BEZERRA, HEBERLE, 2011, p. 541) a partir do lugar que estes ocupam na página da revista. 


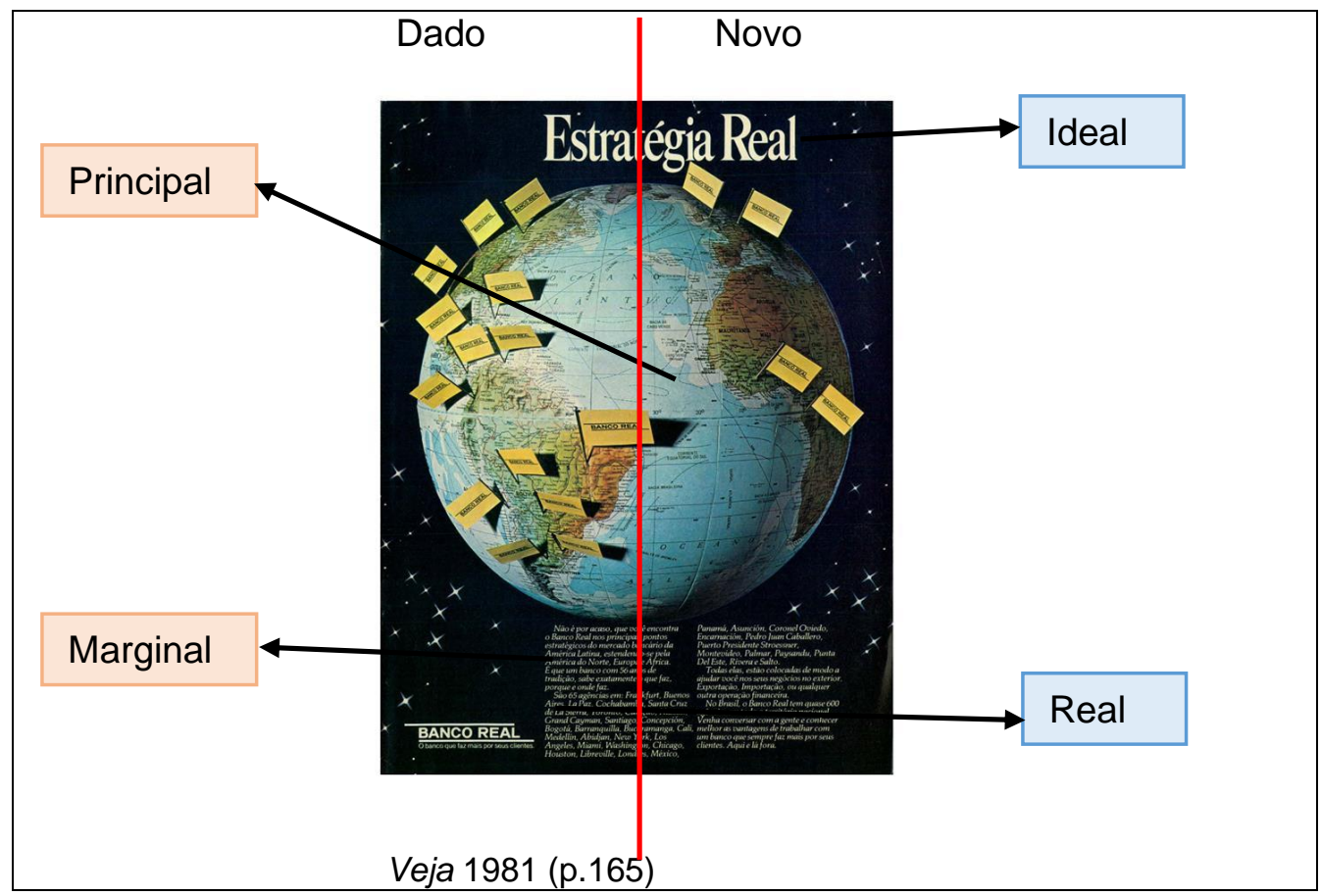

Quanto ao valor da informação - devemos avaliar seus valores a partir das várias "zonas" que se destacam na imagem: esquerda e direita, cima e baixo, centro e margem. Observando a P8, podemos compreender que a informação à esquerda, ou seja, a concentração de bandeirinhas amarelas é o dado (conhecido) que indica que, onde há maior número de agências do Banco Real, há eficiência, transparência, no entanto, a informação à direita é o novo, ou seja, a constatação de que onde as agências do Banco Real são escassas falta luz, claridade, eficácia.

Com relação às informações localizadas no topo (superior) ou base (inferior) da propaganda, também observamos valores diferentes. No topo, está o valor da informação ideal, aquela que apela para nossas emoções, no sentido de expressar o que o produto pode ser e não o que especificamente ele é (KRESS; VAN LEEUWEN, 2006).

- Estratégia Real

Enquanto, na base, está o valor da informação real, aquela que indica quem oferece o produto e onde encontrá-lo. Ex.:

- BANCO REAL - O banco que faz mais por seus clientes. 
Quanto ao centro e à margem da propaganda, podemos identificar o valor da informação principal (centro) e complementar (margem). No centro da P8, encontramos o globo terrestre com as bandeirinhas indicando a localização das agências do Banco Real, já nas margens estão distribuídos os textos contendo a chamada da propaganda, o conteúdo da mensagem do anunciante e a assinatura (logomarca do anunciante) ou ainda a escuridão.

A expressão "Estratégia Real", na parte superior da propaganda, ocupando portanto o valor da informação ideal, pode ser observada somente como a chamada/título da propaganda identificada como $\mathrm{P} 8$, mas também como fator determinante no contexto vivido pelo Brasil da década de 1980, em que as instituições financeiras, assim como o país, estavam submersos numa severa crise econômico-financeira e, apesar disso, tinham que consolidar os seus patrimônios e ampliar os seus negócios. Então, aproveitando-se das várias "aberturas" que a época vislumbrava - dos países, dos muros e da democracia - somando-se ainda ao grande desenvolvimento tecnológico, o Banco Real finca suas bandeiras

- Nos principais pontos estratégicos do mercado bancário [...]

Apesar da crise, o banco contava com 65 agências em vários países e 600 no território nacional, para ajudar o cliente e sua empresa, utilizando, para isso, a estratégia real, no sentido de realidade ou de estratégia do Real (banco), a fim de ampliar os negócios da instituição. Essa informação de valor ideal (superior), que pode ser relacionada a afastamento (frieza de relacionamento), contrasta com a de valor real (inferior), que pode ser relacionada a proximidade, ao convidar o cliente:

- Venha conversar com a gente e conhecer melhor as vantagens de trabalhar com um banco que sempre faz mais por seus clientes. Aqui e lá fora.

A leitura da imagem dessa propaganda - valor principal - dispensa a leitura do texto - valor complementar -, pois deixa claro para qualquer profissional do mundo corporativo (público leitor de uma revista semanal informativa sobre política e economia - Veja) que as bandeirinhas com a logomarca do Banco Real fincadas no globo terrestre enorme - enquadramento e saliência - representam os pontos de atendimento 
(agências), que isso é possível em função do uso de tecnologias e, ainda, que essa é a estratégia do Real para atender às necessidades de seus clientes, leitores da revista Veja, que viajam e que, portanto, podem utilizar os serviços e produtos do banco onde quer que estejam. No entanto, ao fazer uso da linguagem verbal, o anunciante sugere uma conversa pessoal e, com isso, vai construindo com seus clientes uma relação de proximidade, importante para a imagem positiva do Banco.

A propaganda P9, veiculada na revista Exame dos anos 1980, como já mencionado, assemelha-se visualmente à $\mathrm{P} 7$, mas as situações retratadas são bastante diferentes. Nessas imagens, deparamo-nos com um participante masculino envolvido em acontecimentos cotidianos, não para qualquer pessoa, mas para um executivo do mundo corporativo que necessita de serviços como: cobrança, empréstimos, descontos, pagamentos a fornecedores, programa especial para revenda de veículos e, ainda, cheque Realmaster e extrato descomplicado e consolidado, estes últimos constituem o outro participante da cena, ou de uma das cenas, porque, apesar de visualizarmos dois participantes na mesma cena, um não se relaciona com o outro, levando-nos a considerar que se tratam de duas cenas independentes. 


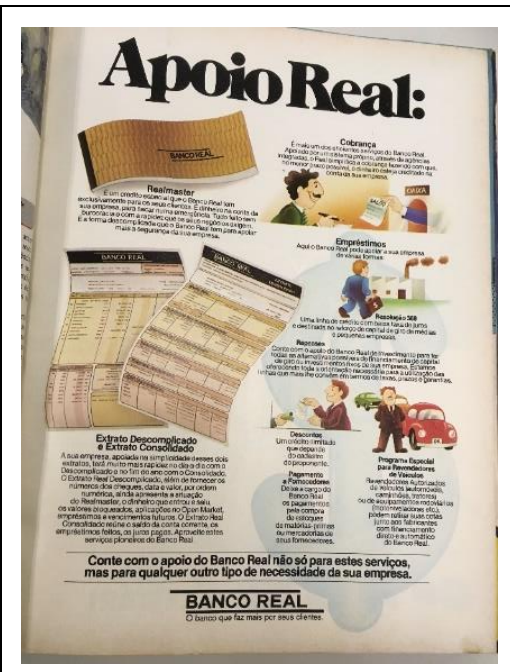

\section{Apoio Real:}

\section{Realmaster}

É um crédito essencial que o Banco Real tem exclusivamente para seus clientes. É dinheiro na conta da sua empresa para sacar numa emergência. Tudo feito sem burocracia e com a rapidez que os seus negócios exigem. É a forma descomplicada que o Banco Real tem para apoiar mais a segurança da sua empresa.

Cobrança

É mais um dos eficientes serviços do Banco Real. Apoiado por um sistema próprio, através de agências integradas, o Real simplifica a cobrança fazendo com que, no menor prazo possível, o dinheiro esteja creditado na conta da sua empresa.

\section{Empréstimos}

Aqui o Banco Real pode apoiar a sua empresa de várias formas:

\section{P9 Exame 1982 (p.166)}

\section{Resolução 388}

Uma linha de crédito com baixa taxa de juros e destinada ao reforço de capital de giro de médias e pequenas empresas.

\section{Repasses}

Conte com o apoio do Bando Real de Investimento para ter todas as alternativas possíveis de financiamento de capital de giro ou investimentos fixos de sua empresa. Estamos oferecendo toda a orientação para a utilização das linhas que mais lhe convém em termos de taxas, prazos e garantias.

\section{Extrato descomplicado e extrato consolidado}

A sua empresa, apoiada na simplicidade desses dois extratos, terá mais rapidez no dia-a-dia com o Descomplicado e no fim do ano com o Consolidado. O Extrato Real Descomplicado, além de fornecer os números dos cheques, data e valor, por ordem numérica, ainda apresenta a situação do Realmaster, o dinheiro que entrou e saiu, os valores bloqueados, aplicações no Open Market, empréstimos feitos, os juros pagos. Aproveite estes serviços pioneiros do Banco Real.

\section{Descontos}

Um crédito ilimitado que depende do cadastro do proponente.

\section{Pagamento a Fornecedores}

Deixe a cargo do Banco Real os pagamentos pela compra de estoque de matérias-primas ou mercadorias de seus fornecedores.

\section{Programa Especial para Revendedores de Veículos}

Revendedores Autorizados de veículos (automóveis, caminhões, tratores) ou de equipamentos rodoviários (motoniveladores etc.) podem retirar suas cotas junto aos fabricantes com financiamento direto e automático do Banco Real.

Conte com o apoio do Banco Real não só para estes serviços, mas para qualquer outro tipo de necessidade de sua empresa.

BANCO REAL - O banco que faz mais por seus clientes

Para melhor compreender nossa análise, o design visual da peça é constituído de desenhos/ilustrações e de imagens fotográficas alocadas de um lado e de outro da página, como se houvesse uma linha divisória bem no centro, separando a expressão "Apoio" para um lado, acima dos participantes estáticos talão de cheques e extratos de 
conta-corrente e a expressão "Real" para o outro lado, acima das cenas que envolvem o participante homem de negócios, como podemos perceber a seguir.

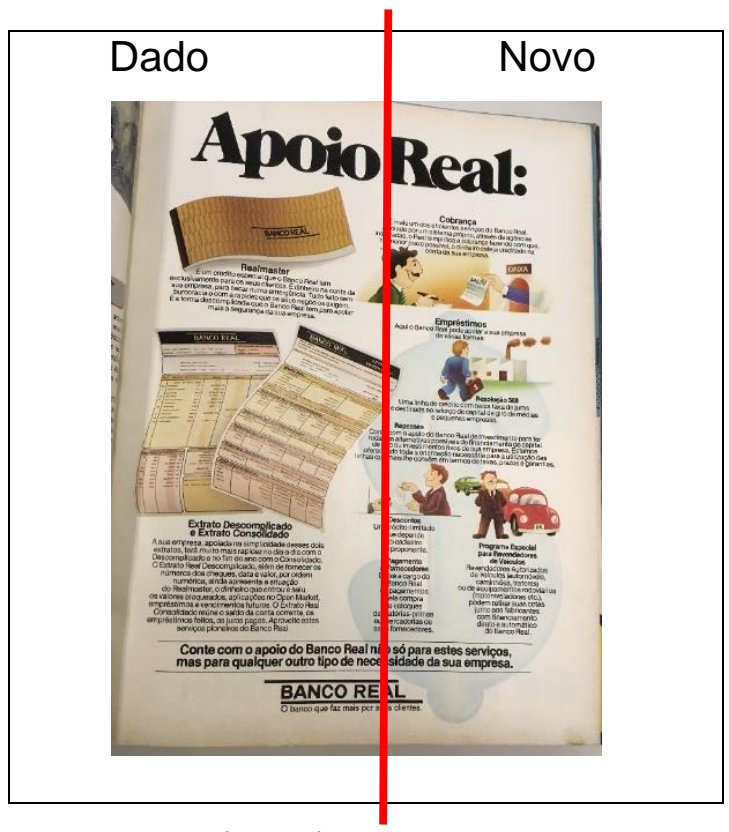

Exame $1982(p .166)$

Do ponto de vista da função de representação, podemos identificar do lado esquerdo do texto multimodal uma representação conceitual simbólica, o talão de cheques e extratos que representam 0 apoio que 0 anunciante pode oferecer ao leitor/cliente: segurança, rapidez e simplicidade. Do lado direito, identificamos a representação narrativa reacional transacional, pois, nas quatro cenas do cotidiano em que o participante está envolvido, podemos reconhecer o alvo de seu olhar (vetor): a mão do caixa do banco apresentando o extrato de saldo; a indústria para a qual o participante se dirige; o dinheiro sacado no caixa. Todas essas cenas representam situações reais para um executivo que trabalha, investe, financia bens. A persuasão ocorre tanto pela linguagem verbal como pela linguagem visual, que apresentam as vantagens concedidas pelos produtos do banco.

No que corresponde à função de interação, o contato é de oferta, participantes dispostos para serem contemplados, pois mesmo na cena em que o participante humano está de frente para o leitor, não parece buscar um contato visual com ele, está ali somente parado, olhando para a frente, orgulhoso dos veículos que está revendendo a partir do financiamento direto e automático. A distância social e perspectiva/atitude demarcadas 
são de plano médio/medium shot nos perfis do participante de lado para o leitor e até de plano aberto/long shot na cena em que se encontra de costas para o leitor, determinando distância ou média proximidade entre os atores. As cenas equivalem à realidade, portanto, trata-se da modalidade naturalista.

Quanto ao modo como os textos multimodais são organizados no espaço da página da revista em análise, observa-se o valor da informação dado/novo, uma vez que o dado (esquerda) incorpora o talão de cheques e extratos bancários e o novo (direita), as oportunidades advindas do crédito e controle daqueles. A saliência é construída pelo destaque da expressão "Apoio Real:", que chama a atenção do leitor para os argumentos apresentados para persuadi-lo a adquirir os produtos e serviços.

Segundo Maingueneau (2013), são o enunciador e coenunciador, momento e lugar que definem a cena enunciativa, ele afirma ainda que "todo enunciado implica um enunciador em relação ao qual é definido o "você", constituído como tal pelo enunciador". Nessa propaganda, percebemos a presença do enunciador a partir das marcas explícitas do coenunciador (seus, sua) e do "nós" da instituição financeira, que está oferecendo o apoio (anunciante):

- É um crédito especial que o Banco Real tem exclusivamente para os seus clientes.

- Aqui o Banco Real pode apoiar a sua empresa de várias formas.

- Conte com o apoio do Banco Real [...] para qualquer outro tipo de necessidade da sua empresa.

- Estamos oferecendo toda a orientação necessária para a utilização das linhas [...]

O momento e lugar da enunciação são marcadas como "aqui" e "agora" em embreantes espaciais e nas marcas verbais.

A imagem pretendida pela instituição financeira, nesta peça, é de "banco apoiador" que se evidencia nos valores de apreciação positiva presentes em:

- É a forma descomplicada que o Banco Real tem para apoiar a segurança da sua empresa.

- Apoiado por um sistema próprio, através de agências integradas, o Real simplifica a cobrança $[\ldots]$

- Conte com o apoio do Banco Real.

- A sua empresa apoiada na simplicidade desses dois extratos, terá mais rapidez [...] 
Outros valores apreciativos são assumidos pelo anunciante, como "rapidez", "segurança", "eficiência", "garantias", "pioneirismo". A evolução tecnológica no sistema bancário que trouxe distância nas relações pessoais com os clientes é também responsável, nessa década, pela conquista dos serviços e aproximação com as vantagens oferecidas. O Banco Real, a partir do seu discurso persuasivo, parece levar a sério a proposição de Brandão (1995, p. 126), "se a relação pessoal é menos intensa, há meios de fazer esse cliente sentir-se privilegiado".

\subsubsection{Década de 1990}

As propagandas da década de 1990 foram selecionadas em revistas dos anos 1997, 1992 e 1995. As propagandas das revistas Veja e Exame são de páginas duplas mais caras para os anunciantes - e a da Claudia é de página simples, mais baratas, mas também com menos espaço para divulgação. Duas delas tratam de datas comemorativas: a recuperação do Jardim Botânico e o Natal e a outra divulga o sistema real de vantagens progressivas.

Em P10, de Claudia, encontramos cores quentes amarelo do ouro e vermelho da sedução, sensualidade. A mulher aparece relaxadamente sentada e sorrindo. A P11, da Veja veicula a ideologia do compromisso com a sustentabilidade - marketing verde produtos ecologicamente corretos sempre agregaram valor aos produtos. P12, de Exame, veicula a linguagem matemática, visualizada pelos símbolos de mais, igual e menos. 


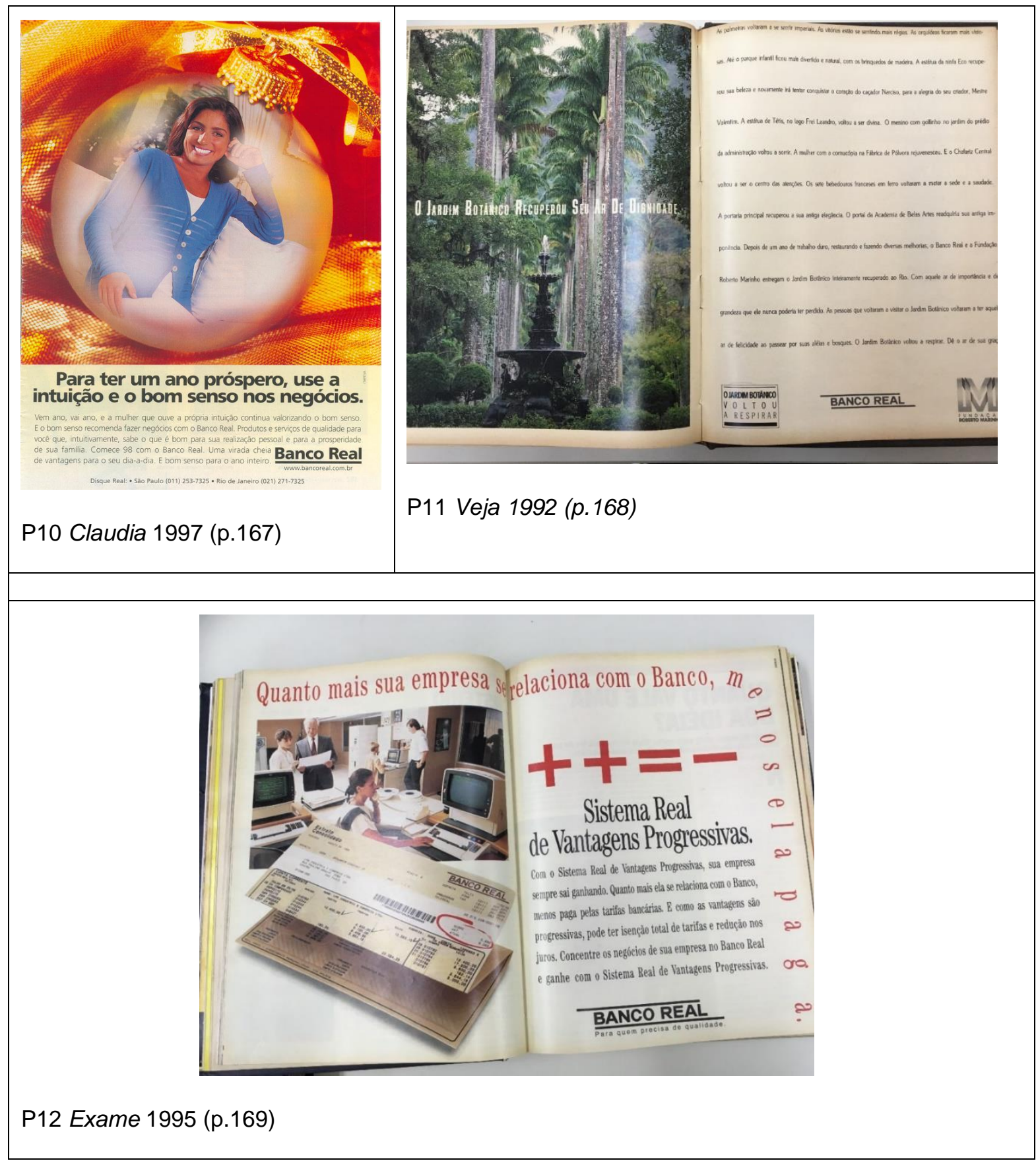

Figura 29 - Propagandas - anos 1990 


\subsubsection{Breve contexto histórico do Brasil e das instituições financeiras na década de 1990}

Houve uma grande mudança no cenário mundial no início dos anos 1990, como o fim do apartheid e a liberação de Nelson Mandela da prisão na África do Sul; a liberação da livre circulação dos alemães pelas duas "Alemanhas"; o reatamento das relações diplomáticas entre Argentina e Inglaterra. Essas mudanças somaram-se aqui no Brasil ao bloqueio das contas-correntes e aplicações em poupança com saldos acima de 50 cruzados novos (moeda corrente da época). Tais medidas reduziram a inflação e refletiram diretamente na vida das instituições financeiras.

Essa década ficou marcada na história do Brasil com o impeachment do então presidente Fernando Collor de Melo e por seus planos econômicos. Em 1994, o ministro da Fazenda Fernando Henrique Cardoso instituiu o Plano Real, baixou a inflação e estabilizou a economia do país.

As instituições financeiras puderam então respirar e trabalhar no intuito de facilitar a vida de seus clientes. As agências bancárias foram reformuladas ampliando o autoatendimento e a possibilidade de o cliente realizar suas operações financeiras sozinho. A tecnologia também propiciou ao "cliente fazer transações sem sair de casa" (BRANDÃO, 1995, p. 72) e encontrar caixas eletrônicos nos mais variados espaços como shopping centers, empresas, faculdades, parques, sem deixar de contar com um espaço aconchegante e privativo nas gerências de agências para um cafezinho e consultoria de negócios.

A década de 1990 se encerra com algumas marcas negativas, como elevada inflação em função da alta do dólar, superávit na Previdência e baixo índice de crianças na escola - cerca de $60 \%$ de crianças e adolescentes estavam fora de escola. Com isso, houve a consequente queda na popularidade do presidente Fernando Henrique Cardoso. Somando-se, ainda, a frustração pela não superação do histórico de país subdesenvolvido. 


\subsubsection{Análise das propagandas dos anos 1990}

Assim como as instituições financeiras puderam respirar e trabalhar para facilitar a vida de seus clientes, as cenas observadas nas propagandas selecionadas do início dos anos 1990 também apresentam momentos de tranquilidade e recuperação.

Em P10, publicada na Claudia, deparamo-nos com uma mulher sorrindo, refletida em uma bola de Natal, sentada relaxadamente em um sofá, como que comemorando as festividades natalinas daquele mês de dezembro.

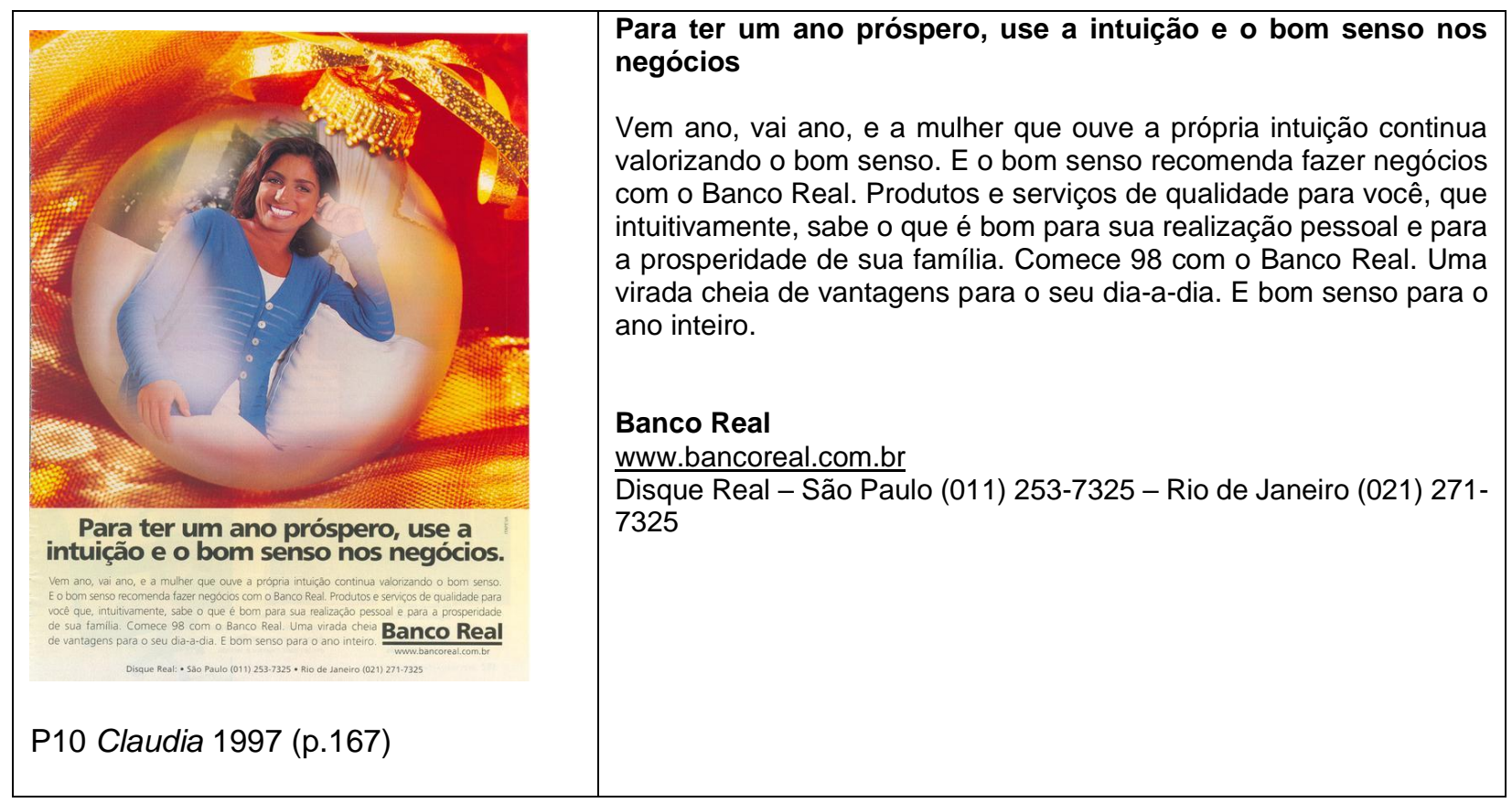

Diferentemente das três propagandas dos anos 1980, nessa peça da revista Claudia, a linguagem visual supera a linguagem verbal em proporção na página multimodal. A imagem apresenta o brilho das bolas de árvore de Natal e tons quentes entre vermelho e o dourado; a mulher envolta nas cores azul e branco, passando a impressão de paz e tranquilidade, destaca-se com um sorriso de alegria e felicidade.

Passamos à descrição e análise subsidiadas pelas categorias da GDV. Com relação à representatividade das imagens, observamos a participante mulher envolvida 
em uma interação com o leitor pelo olhar e pelo sorriso, caracterizando, portanto, a representação narrativa reacional transacional, como podemos observar na imagem a seguir.

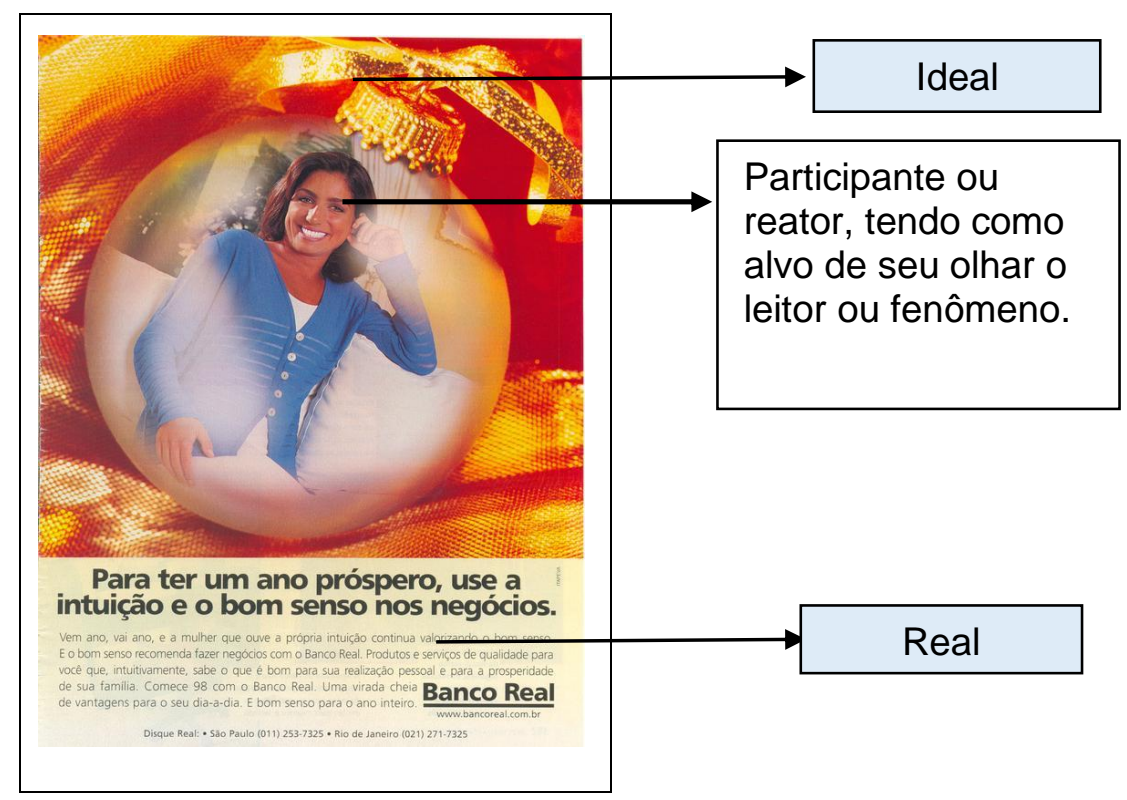

Claudia 1997 (p.167)

No que se refere à função de interação, posto que o contato se dá a partir da linha do olhar do participante para o leitor, temos demanda. Quanto à distância social, mostra proximidade e intimidade entre participante e leitor. $O$ ângulo sob o qual a participante é captada (de frente e num plano de igualdade) corrobora a aproximação e intimidade entre os atores envolvidos na cena. A função de interação também pode ser expressa pela modalidade, que, nesse exemplo, pertence à modalidade naturalista, pelas cores e pela equivalência da cena com a realidade.

Chegando à terceira função descrita por Kress e van Leeuwen (2006) - função de composição - o modo como os textos multimodais são organizados na página da propaganda analisada, observamos o valor da informação ideal/real, pois no topo visualizamos a mulher feliz, confortavelmente sentada, enquanto na base, o texto verbal apresenta as vantagens dos produtos e serviços do Banco Real para a realização pessoal e prosperidade da família da mulher que usa a sua intuição e bom senso. A saliência se dá pelo tamanho da bola e pela iluminação que destaca o amarelo (luxo, ouro) 
envolvendo a participante mulher que, na posição em que se encontra na imagem, parece estar coroada (como uma rainha) pelo pingente da bola com a fita dourada.

Apesar de o texto verbal ocupar um espaço bem menor que a imagem nessa propaganda da Claudia, a argumentação é bastante evidente e relevante. $O$ coenunciador é destacado por uma característica muito comum às mulheres que é a intuição. O apelo argumentativo é repetido diversas vezes no enunciado, as palavras "intuição/intuitivamente" aparecem três vezes e a expressão "bom senso" aparece quatro vezes, reforçando essas qualidades emocionais da mulher. A mulher é recomendada a "fazer negócios com o Banco Real", o que acentua a imagem de mulher autônoma e independente dos anos 1990. Somado a isso, a figura feminina novamente aparece relacionada à "realização pessoal", mas também à "prosperidade de sua família", vinculando a uma figura que conquista seu espaço, busca sua realização, mas não deixa de viver em função de seus familiares.

Os embreantes "você", "sua", "seu" marcam explicitamente a presença do coenunciador. O enunciador é marcado pela logomarca "Banco Real" que assina a propaganda e por quem interage e institui o coenunciador "você". A referência temporal ocorre a partir de embreantes ("comece 98" e "para o ano inteiro") que tomam como base o mês de publicação da revista "dezembro de 1997". Observa-se nesse enunciado uma referência fora do contexto "comece 98" e uma referência pelo contexto "para o ano inteiro".

Observa-se a atitude de afeto para com o leitor, a partir dos valores positivos "intuição" e "bom senso", elogios à mulher - leitora - que, possuindo esses atributos, "sabe o que é bom para sua realização pessoal e prosperidade de sua família". No intuito de acentuar tais características, o enunciador - anunciante - se despede com votos de "boa virada do ano" e "bom senso para o próximo ano inteiro":

- Uma virada cheia de vantagens para o seu dia-a-dia. [sic]

- E bom senso para o ano inteiro.

A segunda peça a ser analisada dessa década é a P11, veiculada na revista Veja, em 1992. Trata-se de uma propaganda de página dupla, composta por $50 \%$ imagem do 
Jardim Botânico e 50\% de texto valorizando a obra de recuperação de cada detalhe do parque que, metaforicamente, como um grande pulmão "volta a respirar" e ganha "ar de dignidade".

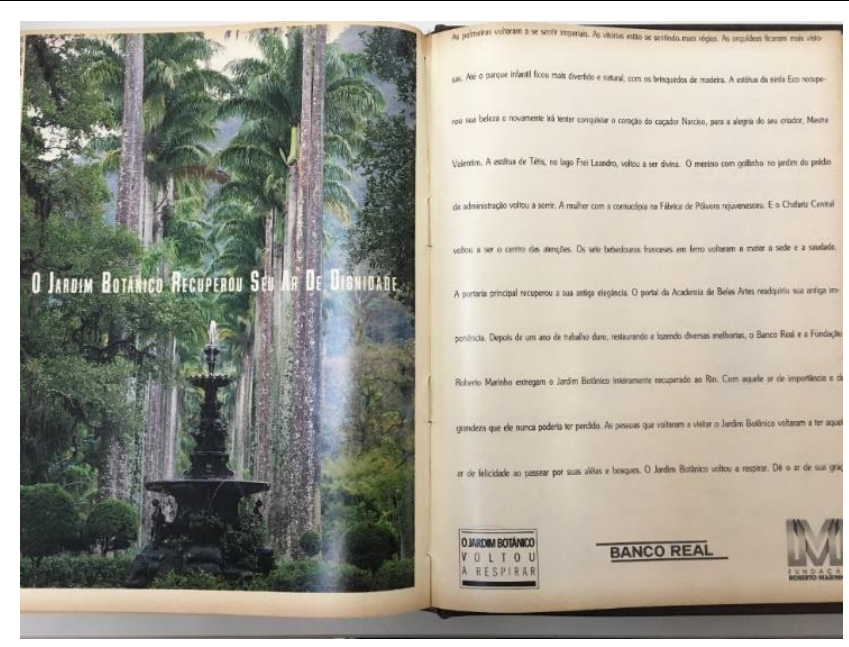

P11 Veja 1992 (p.168)

\section{O Jardim Botânico Recuperou Seu Ar De Dignidade}

As palmeiras voltaram a se sentir imperiais. As vitórias estão se sentindo mais régias. As orquídeas ficaram mais vistosas. Até o parque infantil ficou mais divertido e natural, com os brinquedos de madeira. A estátua da ninfa Eco recuperou sua beleza e novamente irá tentar conquistar o coração do caçador Narciso, para a alegria do seu criador, Mestre Valentim. A estátua de Télis, no Lago Frei Leandro, voltou a ser divina. O menino com golfinho no jardim do prédio da administração voltou a sorrir. A mulher com a cornucópia na Fábrica de Pólvora rejuveneceu. E o Chafariz Central voltou a ser o centro das atenções. Os sete bebedouros franceses em ferro voltaram a matar a sede e a saudade.

A portaria principal recuperou a sua antiga elegância. O portal da Academia de Beles Artes readquiriu sua antiga imponência. Depois de um ano de trabalho duro, restaurando e fazendo diversas melhorias, o Banco Real e a Fundação Roberto Marinho entregaram o Jardim Botânico inteiramente recuperado ao Rio. Com aquele ar de importância e de grandeza que ele nunca poderia ter perdido. As pessoas que voltaram a visitar o Jardim Botânico voltaram a ter aquele ar de felicidade ao passear por suas aléias e bosques. O Jardim Botânico voltou a respirar. Dê o ar de sua graça.

\section{O JARDIM BOTÂNICO \\ $\mathrm{O}$
$\mathrm{O}$ $\mathrm{L} O \mathrm{O}$ \\ A RESPIRAR \\ BANCO REAL}

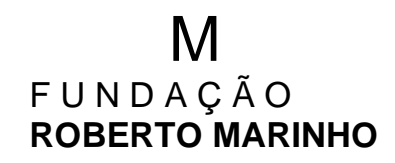


No que se refere à função de representação, essa propaganda insere-se na representação conceitual simbólica, pois apresenta o participante pelos seus atributos e identidades, há ausência de vetor e exclusão ou diminuição de detalhes do pano de fundo. Na página da esquerda, em que visualizamos o Jardim Botânico, também identificamos o processo analítico, posto que há uma relação da parte pelo todo. $O$ chafariz e as palmeiras imperiais estão representando todo o parque que tem lago, estátuas, bebedouros, entre outros atrativos.

No que corresponde à função de interação, a imagem se dá por um contato de oferta, como em outras propagandas anteriores, a beleza e o verde servindo para a contemplação do leitor. No que diz respeito à distância social, apresenta o plano fechado/closep-up ou relação de intimidade e receptividade entre o participante parque e o leitor. No plano da perspectiva/atitude, o participante é captado por um ângulo frontal, participante no mesmo nível do leitor, determinando uma relação de igualdade.

No tocante à função de composição, o texto multimodal está organizado em P11 sob o valor da informação: dado (esquerda) e novo (direita). A informação do lado esquerdo da propaganda (dado) destaca o Jardim Botânico que é conhecido pela população do Rio de Janeiro, enquanto a informação da página da direita traz a novidade descrita em detalhes, cada parte que fora recuperada, tornando o parque todo repaginado (novo).

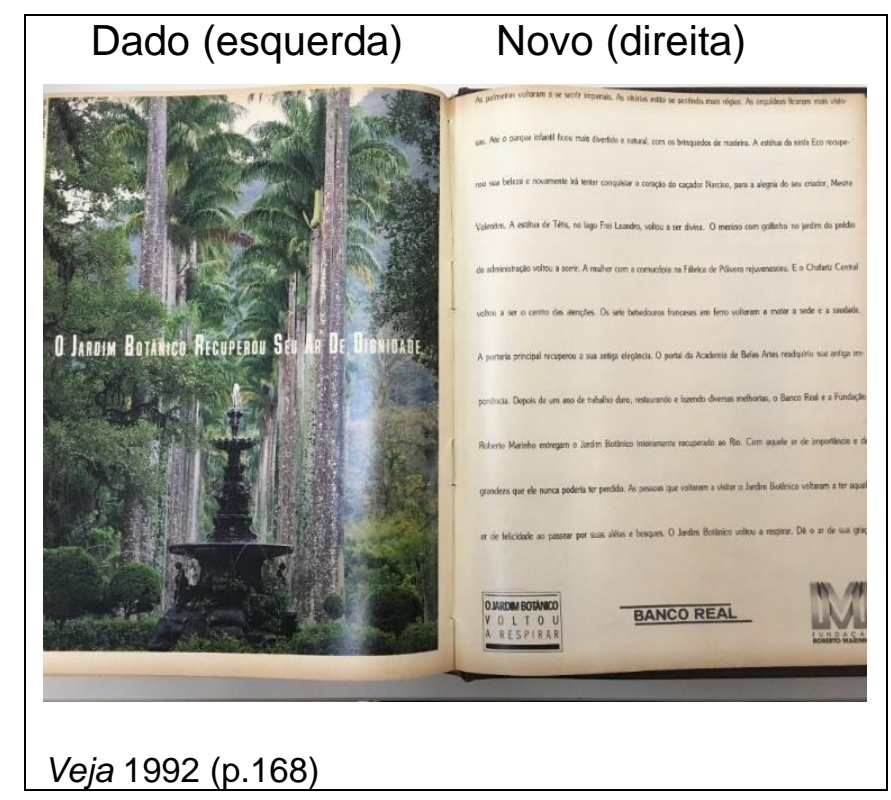


A saliência se dá pelo tamanho das palmeiras imperiais formando uma alameda convidativa para os frequentadores adentrarem ao parque, assim como pelo predomínio do verde que representa o ar puro que poderá ser respirado lá dentro.

O enunciado construído na página da direita é poético e, consequentemente, metafórico.

- O Jardim Botânico recuperou seu ar de dignidade.

- As palmeiras voltaram a se sentir imperiais.

- As vitórias estão se sentindo mais régias.

- A portaria principal recuperou a sua antiga elegância.

- Depois de um ano de trabalho duro.

Após uma vasta descrição poética das transformações realizadas, surgem os autores das "diversas melhorias", o "Banco Real e a Fundação Roberto Marinho" que tiveram "um ano de trabalho duro" para que a população pudesse voltar a frequentar o parque e a ter "aquele ar de felicidade". O tempo presente (agora) demarcado no enunciado é representado pela expressão "depois de um ano" do início do trabalho de recuperação e o aqui é a cidade do "Rio".

Como já evidenciado no parágrafo anterior, as relações estabelecidas entre o anunciante e o leitor envolvem valor de afeto positivo:

- As pessoas que voltaram a visitar o Jardim Botânico voltaram a ter aquele ar de felicidade ao passear por suas aléias [sic] e bosques.

Há ainda uma atitude de julgamento do enunciador quanto aos responsáveis que deixaram o parque deteriorar, perdendo atributos que ele "nunca poderia ter perdido", como segue:

- Com aquele ar de importância e de grandeza que ele nunca poderia ter perdido.

A próxima propaganda, terceira dos anos 1990, circulou na revista Exame. Também é de página dupla, ocupadas à esquerda por uma cena de escritório de empresa e à direita por texto verbal e sinais matemáticos. 


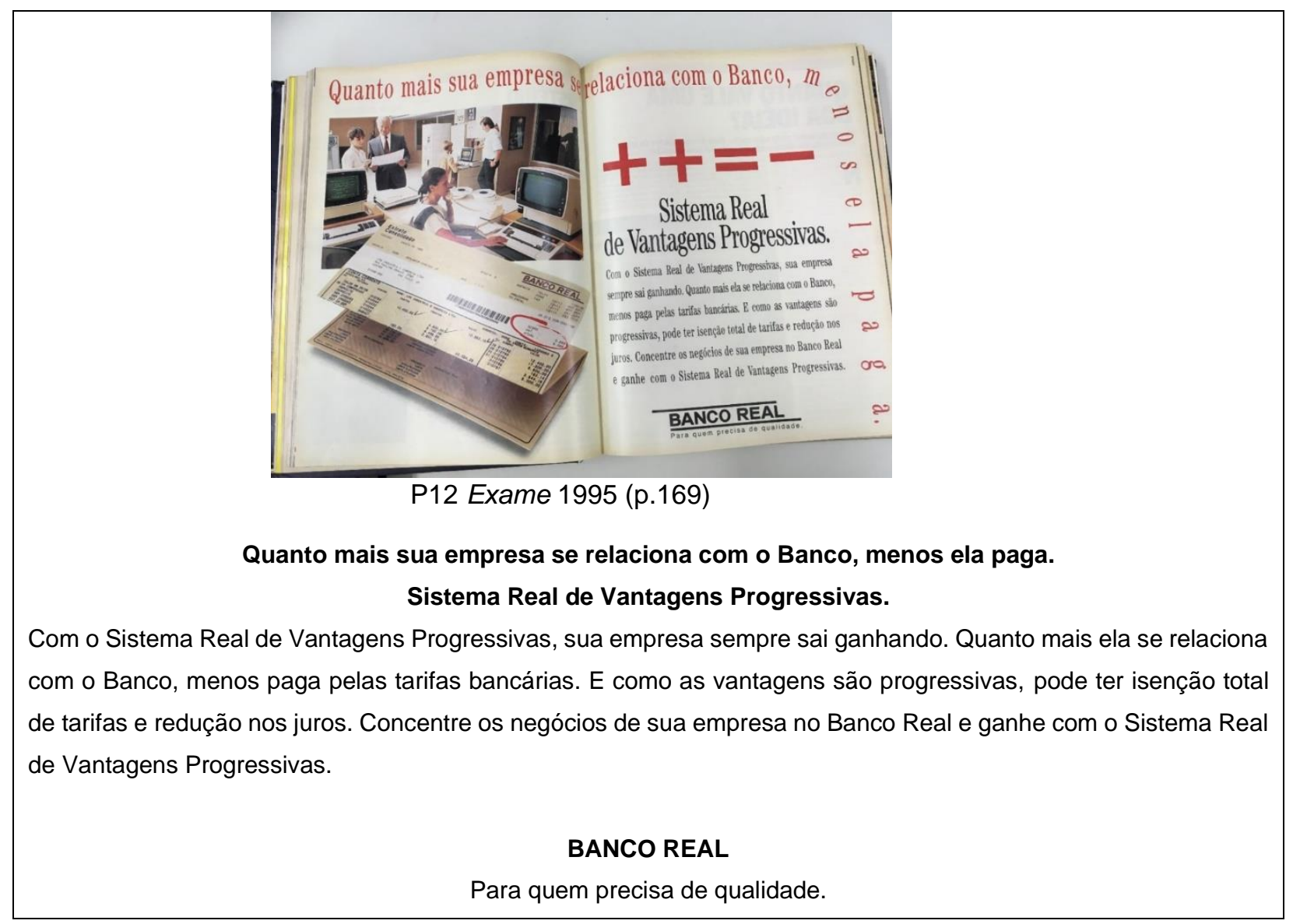

Partindo das categorias da GDV, percebemos que, no que se refere à função de representação, a $\mathrm{P} 12$ apresenta uma cena que envolve a representação narrativa reacional transacional, em que é possível identificar o alvo do olhar dos participantes humanos em direção aos participantes (metas), representados pelo documento nas mãos do senhor em pé e a tela do computador das moças sentadas, como podemos observar na indicação a seguir: 


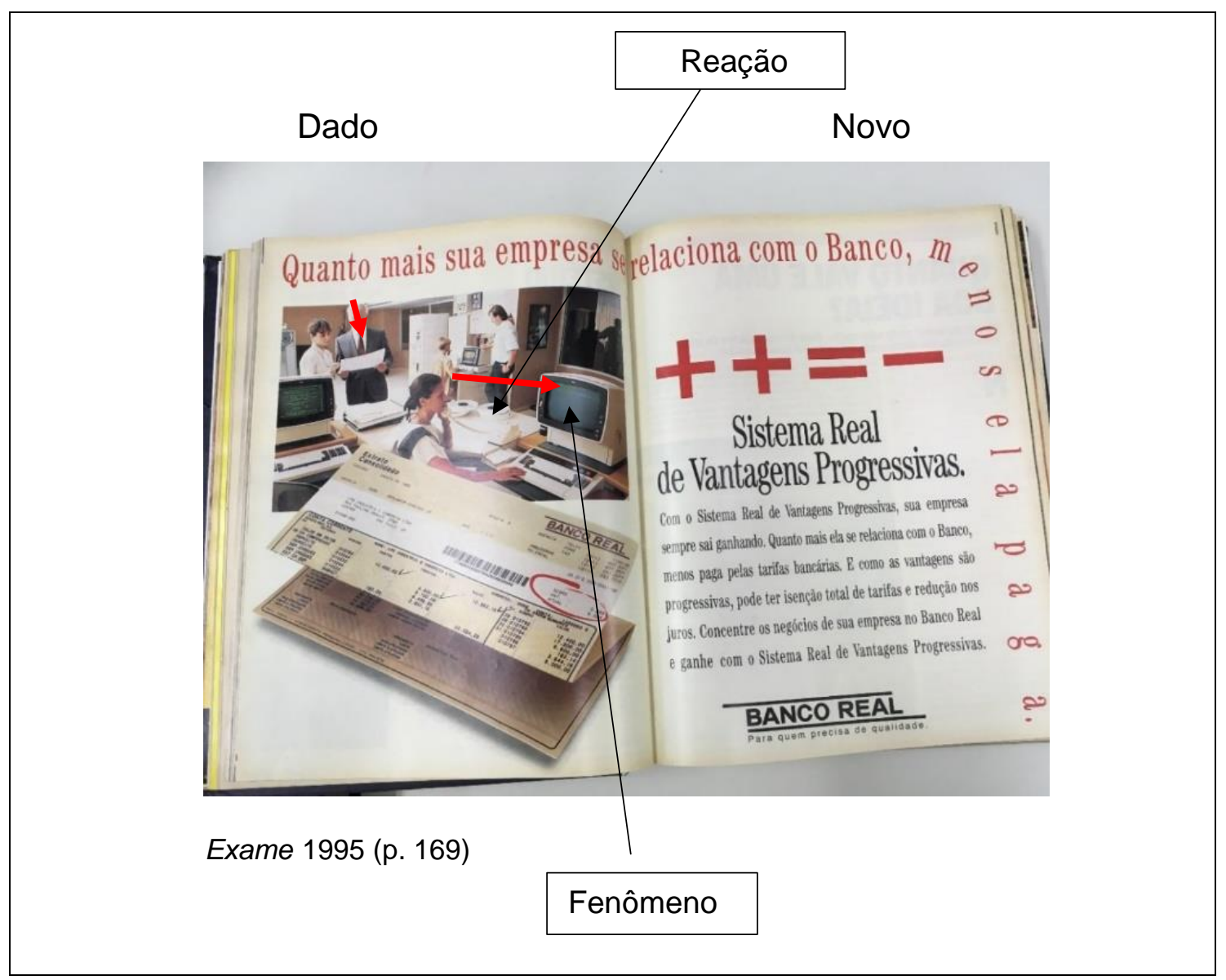

No mesmo lado da página, podemos visualizar um participante objeto (extrato de conta-corrente), que representa as transações realizadas no Banco Real, equivalentes ao relacionamento do cliente empresa com o anunciante banco. Na página do lado direito, os sinais de mais, igual e menos, ou seja, "quanto mais" a "empresa se relaciona com o banco, menos ela paga" tarifas.

No que toca à função de interação, o contato ocorre de forma indireta - oferta. A distância social é marcada pelo plano aberto/long shot; quanto à perspectiva/atitude, os participantes estão todos de lado para o leitor evidenciando distanciamento e um nível de poder de igualdade.

Quanto à função de composição, percebemos o valor da informação dado $x$ novo. O dado (conhecido) é o dia a dia empresarial que envolve consultas (em extrato impresso ou na tela do computador) e decisões a serem tomadas com agilidade e 
segurança; e o novo é o "Sistema de Vantagens Progressivas" do Banco Real - "para quem precisa de qualidade".

O Sistema de Vantagens Progressivas foi criado para as empresas, por isso, o enunciado é dirigido ao coenunciador responsável pela empresa a partir dos embreantes "sua" e "ela". A presença do enunciador ocorre por interpelações do coenunciador como nos imperativos "concentre" e "ganhe".

No tocante ao sistema de valoração (ou avaliatividade), ocorre uma atitude de julgamento de sansão social, em que a instituição financeira - Banco Real -, envolto naquele momento histórico de estabilização da economia e baixa da inflação, assume 0 comportamento de justiça para com seu público-alvo, concedendo a ele "isenção de tarifas" e "redução nos juros". Construindo junto ao leitor da revista - executivos do mercado econômico e financeiro - uma imagem altamente confiável e crível.

\subsubsection{Década de 2000}

A seguir, as três propagandas selecionadas nas revistas da década de 2000, sendo duas do ano 2003 (Claudia e Exame) e uma de 2008 (Veja). Todas corroboram a tendência do século $X X I$, que são propagandas de página dupla, já presentes em décadas anteriores, coloridas e compostas por figuras humanas. 


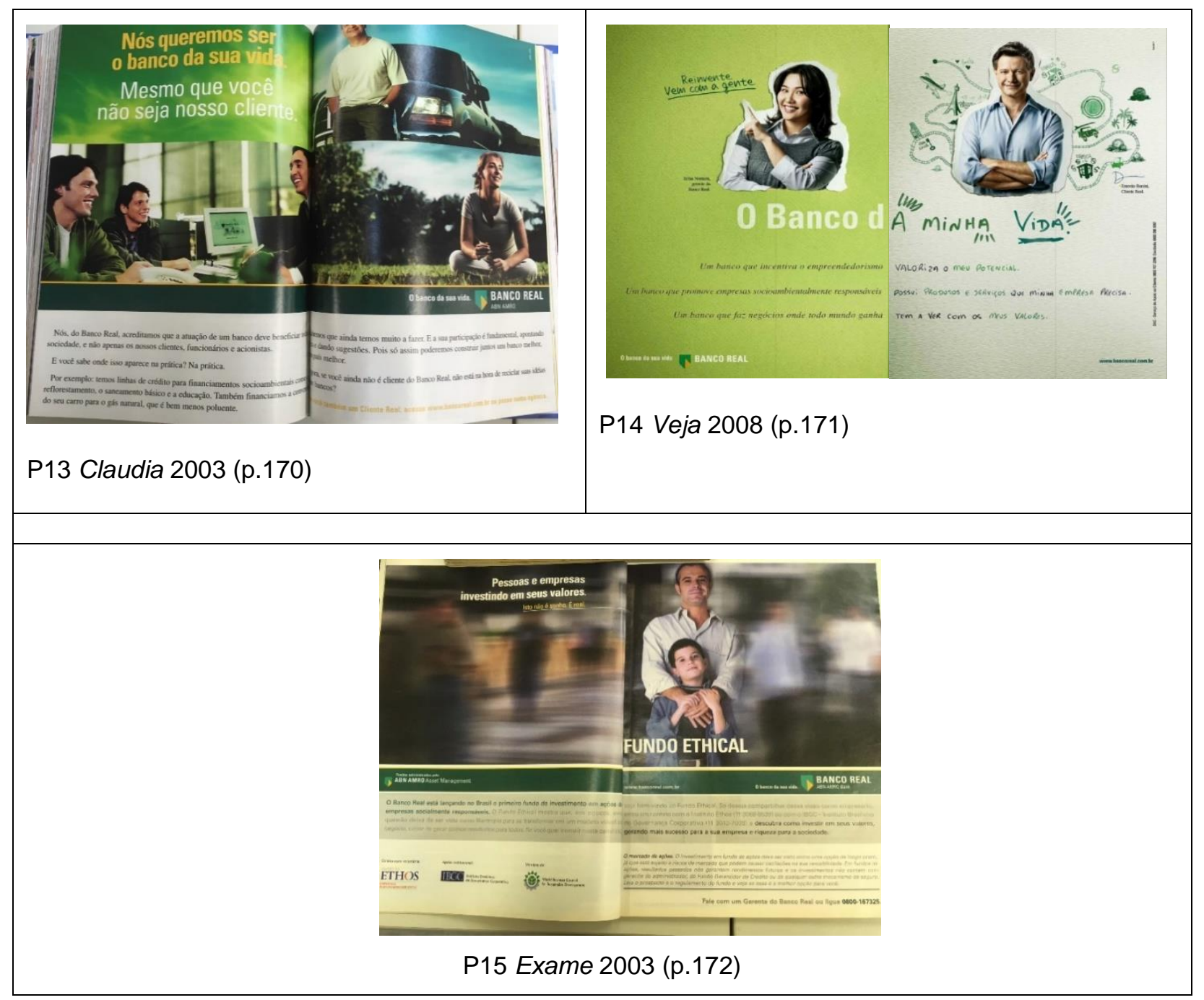

Figura 30 - Propagandas - anos 2000

\subsubsection{Breve contexto histórico do Brasil na década de 2000}

As crises dos anos 1990 levaram o Brasil a iniciar essa nova década com uma série de grandes desafios: baixar a inflação, melhorar o quadro de impopularidade do presidente Fernando Henrique Cardoso, melhorar o índice de crianças nos bancos escolares, diminuir o analfabetismo, gerar melhorias no setor da saúde e ainda superar o subdesenvolvimento do país. 
Segundo Jaguaribe (2000) ${ }^{19}$, em seu artigo "Brasil: dilemas e desafios", "O futuro é sempre especificamente imprevisível. A continuada aceleração da história, desde o início dos tempos modernos [...], torna particularmente impossível qualquer antecipação do que concretamente venha a ser o século XXI". Apesar disso, arrisca-se a pensar em duas grandes tendências: o processo de globalização e a formação de uma nova ordem mundial.

Retomado o crescimento econômico do país, houve o avanço da formalização do emprego, a diminuição da pobreza e uma significativa redução da desigualdade social e, com isso, surgiu uma nova nomenclatura no país, uma nova classe média. Esta nova nomenclatura e o novo status social decorreram de fatores político-econômico-sociais como redução de custos dos bens, aumento da renda, diminuição da desigualdade social, crescente incorporação da mulher no mercado de trabalho e diminuição do tamanho das famílias (KREIN, 2014) ${ }^{20}$. Esses fatores resultaram na ampliação do acesso ao consumo de uma maior parte da população: a nova classe média.

Para o mundo e para o país, essa foi a década da transformação. "Nunca tantas mulheres foram eleitas democraticamente para chefias do Estado, em tantos países tão importantes, quanto nos anos [20]00"21. Em matéria intitulada "37 revoluções: a década da transformação", a revista Superinteressante, denomina os anos 2000 como "a década mais revolucionária da história", pois nela os indivíduos ficaram "mais conectados, mais ricos, mais siliconados, mais rápidos". Acrescenta ainda que essa década divide o planeta em "antes e depois", a internet invadiu a casa e a vida das pessoas, inclusive pelos celulares; criou-se a possibilidade de assistir à vida de pessoas anônimas pela televisão; houve grande desenvolvimento da tecnologia; criação de novas redes sociais, como Orkut; aprovação da primeira lei para garantir o direito das mulheres a uma vida livre de violência - Lei Maria da Penha.

\footnotetext{
19 Disponível em: <http://www.scielo.br/scielo.php?script=sci_arttext\&pid=S0103-40142000000100010>. Acesso em: 14 mar. 2019.

20 Disponível em: <http://www.scielo.br/scielo.php?script=sci_arttext\&pid=S0103-40142014000200020>. Acesso em: 14 mar. 2019.

${ }^{21}$ Disponível em: <https://super.abril.com.br/ciencia/37-revolucoes-a-decada-da-transformacao/>. Acesso em: 14 mar. 2019.
} 
Para as instituições financeiras, a consequência positiva de toda a transformação ocorrida nessa década foi a expansão do uso de cartões de crédito e débito, chegando a ser quadriplicado. $O$ acesso à internet também otimizou os pagamentos de contas online e a necessidade de novamente remodelar as agências bancárias, aumentando o espaço de caixas eletrônicos e diminuindo o espaço de atendimento pessoal e personalizado. Mais máquinas, menos pessoas para atender o cliente, que passa a necessitar de mais eficácia nas propagandas para manutenção da aproximação entre o banco e clientes.

\subsubsection{Análise das propagandas dos anos 2000}

As três peças publicitárias selecionadas dos anos 2000 têm em comum imagens no topo da página e texto verbal na base. As imagens veiculam participantes humanos em situação de negociação comercial ou em lugar de descanso na natureza reflorestada ou ainda exibindo bens de consumo socioambientalmente responsáveis - como o automóvel na propaganda de Claudia, enfim, as pessoas parecem representantes da nova classe média em ascensão naquela década. As três propagandas falam de valores éticos e socioambientais.

$\mathrm{Na}$ busca pela aproximação com o leitor, o anunciante interpela-o com o desejo de "ser o banco da sua vida" e, diferentemente da maioria das propagandas analisadas até aqui, o enunciador aparece de maneira direta, explícita e clara nos embreantes "nós" e "nosso" repetidas vezes e em verbos na primeira pessoa do plural do presente do indicativo como: "acreditamos", "temos", "financiamos", "sabemos", constantes da propaganda a seguir, veiculada na revista Claudia, em agosto de 2003. 


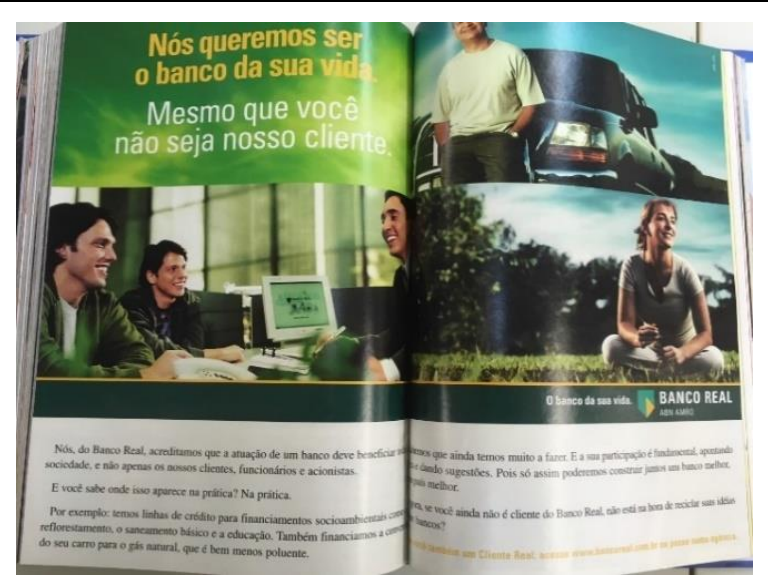

P13 Claudia 2003 (p.170)

Nós queremos ser o banco da sua vida.

Mesmo que você não seja nosso cliente.

Nós, do Banco Real, acreditamos que a atuação de um banco deve beneficiar toda a sociedade, e não apenas os nossos clientes, funcionários e acionistas.

E você sabe onde isso aparece na prática? Na prática.

Por exemplo: temos linhas de crédito para financiamentos socioambientais como o reflorestamento, o saneamento básico e a educação. Também financiamos a conversão do seu carro para o gás natural, que é bem menos poluente. Sabemos que ainda temos muito a fazer. E a sua participação é fundamental, apostando e dando sugestões. Pois só assim poderemos construir juntos um banco melhor, um país melhor.

Agora, se você ainda não é cliente do Banco Real não está na hora de reciclar suas ideias sobre bancos?

Seja você também um cliente Real: acesse www.bancoreal.com.br ou passe numa agência.

Os participantes da primeira cena, na página da esquerda, interagem, aparentemente em um contexto de visita à gerência de uma agência do Banco Real (cliente ou não cliente). Nessa cena, podemos identificar a função de representação narrativa reacional transacional envolvendo três participantes e vetores representados pelos olhares que dirigem um ao outro (reator e fenômeno). Os outros dois participantes, nas cenas da página da direita, um em cada cena, olham sorridentes para alguém ou algo não identificado. Nesse caso, observamos representações narrativas acionais não transacionais.

No que se refere à função de interação, o contato é de oferta; a distância social é de plano médio/medium shot - relação de nível social entre os participantes e o leitor. O ângulo oblíquo da maioria dos participantes e de igualdade em todas as cenas confirma a relação de médio distanciamento e igualdade entre o participante da cena retratada e o participante interativo ou leitor. A modalidade é naturalista. 
No que diz respeito à função de composição, o valor da informação encontra-se dividido entre ideal $\times$ real, no topo visualizamos cenas do dia a dia de pessoas que partilham do ideal de "reflorestamento, o saneamento básico, a educação" e ainda a "conversão de seu carro para gás natural que é menos poluente"; na base do texto multimodal encontramos a descrição das ações/práticas do banco como linhas de crédito para financiamentos socioambientais, mas "que ainda tem muito a fazer" e, por isso, convida o leitor a participar apoiando e sugerindo, pois somente assim é possível "construir juntos um país melhor".

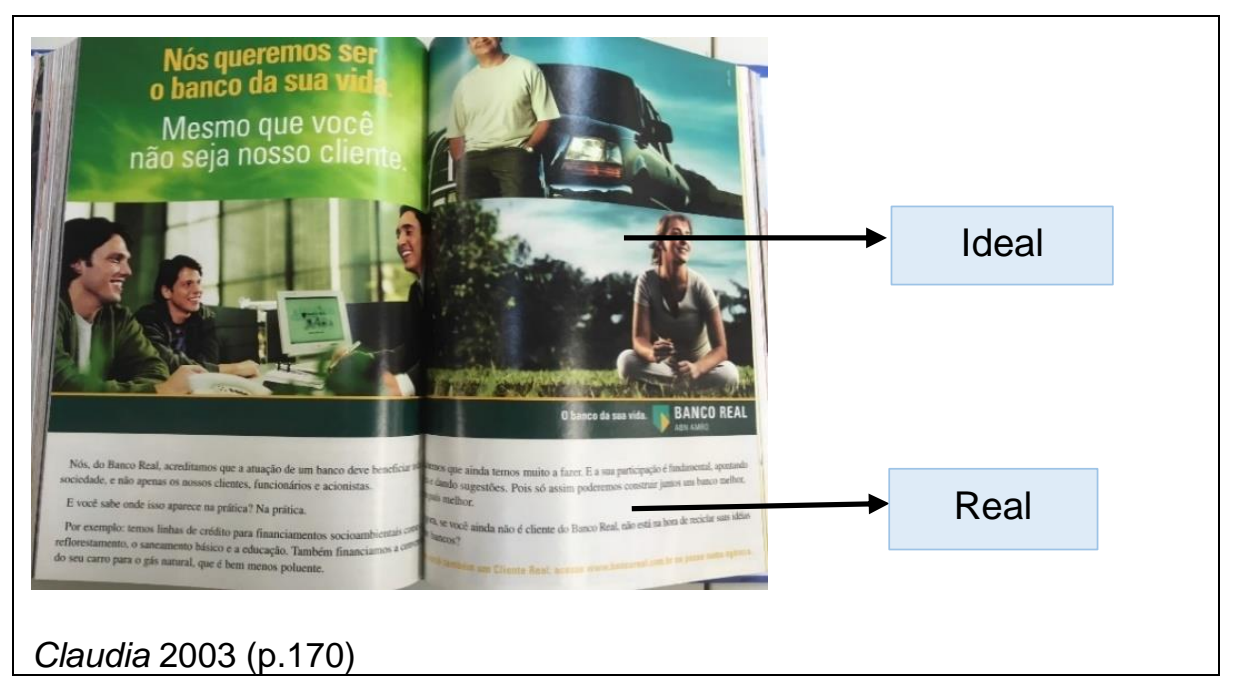

O coenunciador, assim como o enunciador, é bastante evidenciado nos enunciados da propaganda: "você", "seu" e "sua". O coenunciador é ainda questionado pelo enunciador duas vezes:

- E você sabe onde isso acontece na prática? Na prática.

- Agora, se você ainda não é cliente do Banco Real não está na hora de reciclar suas ideias sobre bancos?

Os embreantes de "aqui" - país - e "agora" - tempo presente do indicativo, também estão marcados no enunciado.

Deparamo-nos nessa peça publicitária com o valor de julgamento de estima social das pessoas do banco para com a sociedade a partir de ações práticas de 
responsabilidade socioambiental, representadas por "financiamentos socioambientais" e financiamento para a "conversão do seu carro para o gás natural".

- Nós, do Banco Real, acreditamos que a atuação de um banco deve beneficiar toda a sociedade, e não apenas os nossos clientes, funcionários e acionistas.

- Temos linhas de crédito para financiamentos socioambientais como o reflorestamento, o saneamento básico e a educação.

- Também financiamos a conversão do seu carro para gás natural, que é menos poluente.

Essa atitude de julgamento acaba resultando em atitude de apreciação que constitui o anunciante Banco Real e que, apesar de estar fazendo muito, reconhece que "ainda tem muito a fazer" e convida a participação do público-alvo "apostando" e "dando sugestões":

- Pois só assim poderemos construir juntos um banco melhor, um país melhor.

Tais atitudes contribuem para a construção de uma imagem institucional de eficácia, ética, responsabilidade social, virtuosidade, confiabilidade. $O$ anunciante mostra sua identidade pelo modo como envolve o leitor na prática dessas ações sociais por meio de um discurso franco e transparente em que "juntos", num trabalho em equipe, construirão um país melhor.

A segunda propaganda da década, publicada em agosto de 2008, na Veja, contrariamente à anterior, traz a declaração dos atores da cena:

- O Banco da minha vida.

O texto da sequência está dividido em dois blocos, um com argumentos da moça e o outro com argumentos do rapaz. A participante feminina faz um convite ao leitor:

- Reivente. Vem com a gente. 
Relativamente à função de interação, encontramos o contato por demanda - os participantes olhando diretamente para o leitor - demarcando uma relação pessoal. Quanto à proximidade ou distanciamento entre os participantes e leitor, observa-se o plano médio/medium shot - relação social. No campo da perspectiva/atitude, nota-se mais intimidade em função de o participante ter sido captado de frente para o leitor e o nível de poder é de igualdade entre eles. Modalização naturalista.

Do ponto de vista da função de composição, o valor da informação encontra-se dividido entre ideal $\times$ real, no topo, visualizamos os participantes e, na base, texto verbal relacionando os benefícios e valores reconhecidos nas falas dos próprios participantes em cena.

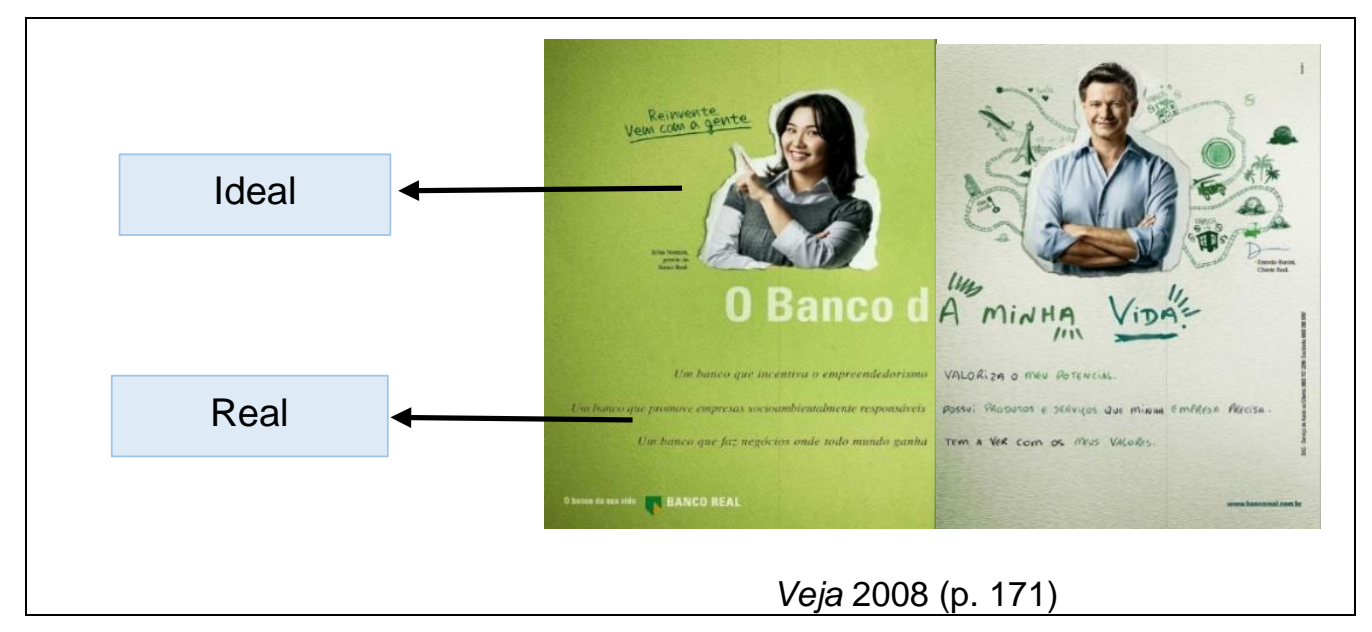

No tocante aos valores, notamos atitude de apreciação positiva por parte dos participantes da cena que declaram o Banco Real como "o banco da minha vida", pois encontram nessa instituição mais do que produtos e serviços, mas incentivo, ações socioambientais, ética nos negócios e, o mais importante, os "valores", com os quais o público-alvo se identifica.

$\mathrm{Na}$ década em que diversas mulheres assumem o poder e aumentam sua participação no mercado de trabalho, elas são representadas na propaganda em análise, dividindo o espaço "meio a meio" com o homem. Identificação parece ser a palavra de ordem nesse contexto histórico. $O$ anunciante se identificando com os valores do seu público-alvo. 
Essa terceira peça selecionada dos anos 2000 para análise (P15) é do produto Fundo Ethical, que, diferentemente dos exemplos anteriores, aparece com destaque. A imagem visual ocupa grande proporção do espaço da propaganda de página dupla e é de dois participantes - aparentando uma relação de pai e filho - e a chamada "Pessoas e empresas investindo em seus valores". Metaforicamente, pode-se pensar em "valores passados de pais para filhos".

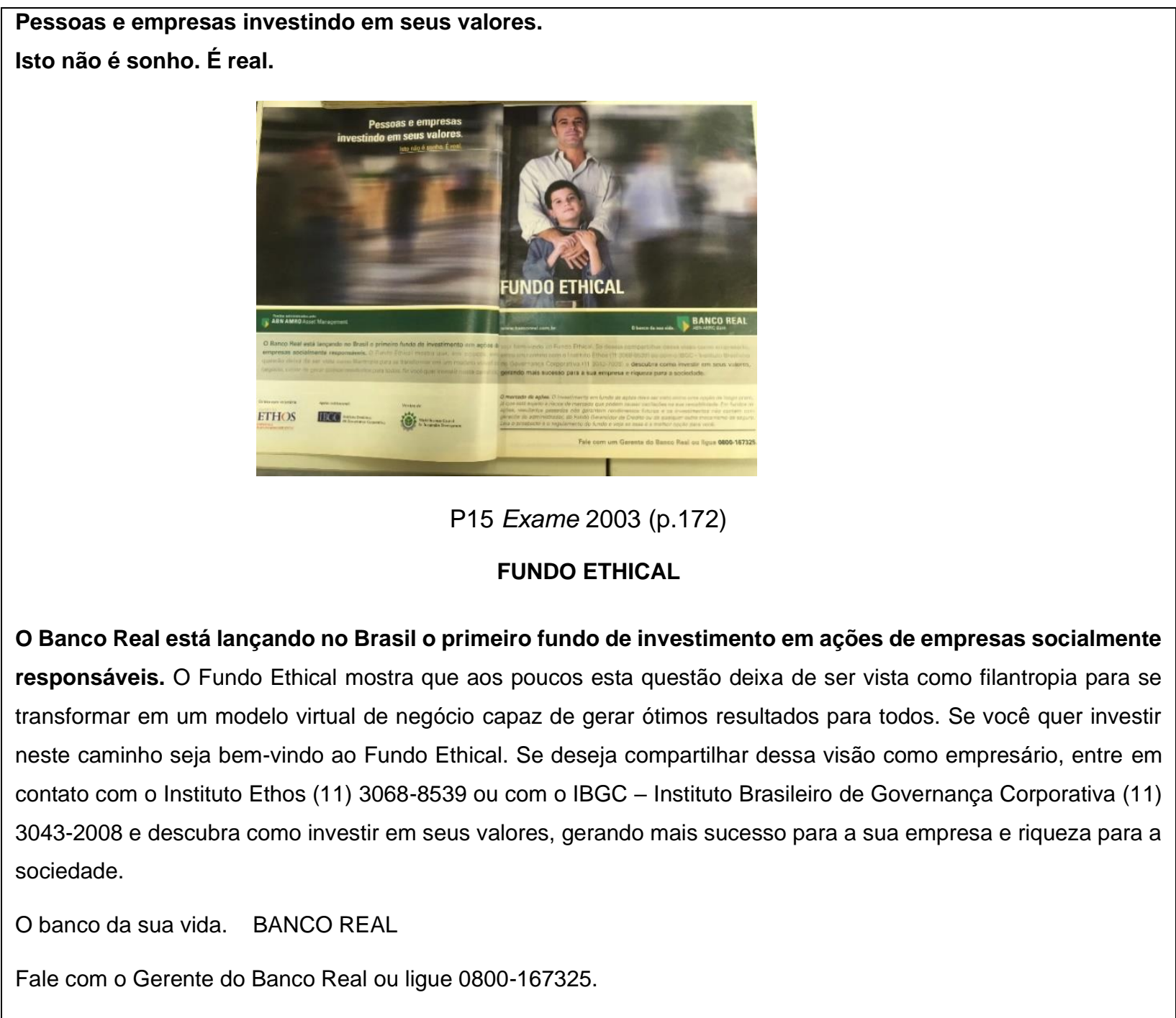

Relativamente à função de representação narrativa reacional transacional, observa-se o olhar dos participantes dirigido ao leitor/observador. 
Quanto à função de interação, encontramos o contato por demanda - os participantes olhando diretamente para o leitor - demarcando uma relação pessoal. No tocante à proximidade ou distanciamento entre os participantes e leitor, observa-se o plano médio/medium shot - relação social. No campo da perspectiva/atitude, nota-se mais intimidade em função de o participante ter sido captado de frente para o leitor e o nível de poder é de igualdade entre eles. Modalização naturalista, como em P14.

Do ponto de vista da função de composição, o valor da informação encontra-se dividido entre ideal $\times$ real, no topo, visualizamos os participantes e, na base, texto verbal relacionando os benefícios e valores reconhecidos nas falas dos próprios participantes em cena.

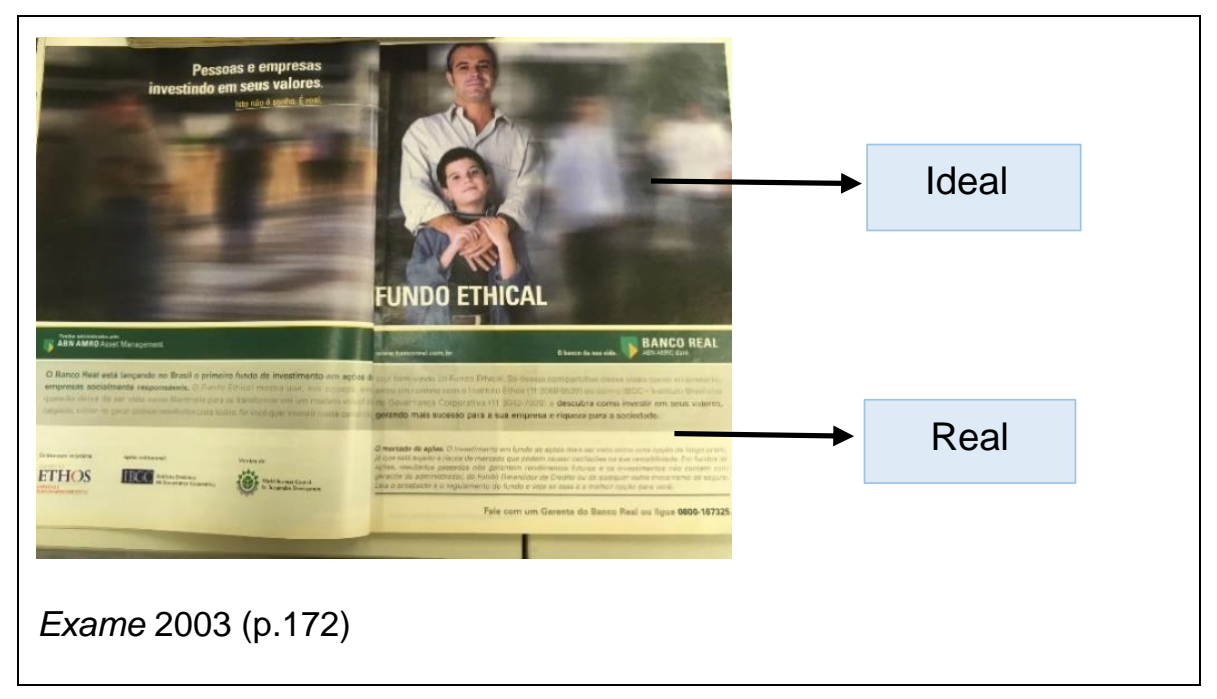

O enunciado que também compõe a imagem "Isso não é sonho. É real" remete a algumas interpretações. Uma delas é de que atrás dos participantes principais há vultos de pessoas em movimento, porém uma nebulosidade proposital leva a cena a uma possibilidade de sonho, então, a cena de fundo representa o sonho e a imagem nítida dos participantes representa o real (a realidade). Outra interpretação pode estar relacionada somente ao plano linguístico em que "pessoas e empresas investindo em seus valores" é real, realidade tão perfeita que leva a acreditar que é sonho.

No plano de enunciação, ocorrem embreantes como "você", "seus", "sua", e os imperativos "entre", "seja" e "descubra" corroboram a enunciação e marcam a presença 
do coenunciador, tempo e espaço da cena. O enunciador é marcado pela instituição do "você" - o coenunciador.

O enunciado trata de investimento, não em ações ou outros produtos bancários, mas em valores que geram "sucesso para as empresas e riqueza para a sociedade". No slogan observamos uma atitude de apreciação positiva do Banco Real, que se intitula o "Banco da sua vida", inscrição identificada também na propaganda P14, analisada anteriormente.

\subsubsection{Década de 2010}

As três últimas peças a serem analisadas são respectivamente dos anos $2010 \mathrm{e}$ 2018, todas da marca Santander, grupo espanhol que incorporou o Banco Real no ano de 2008, mas somente em 2010 teve o nome Santander em todas as fachadas das agências do antigo Real.

Apesar da tendência de página dupla, as duas propagandas de 2018 são de páginas simples. Exceto a da revista Claudia, as demais são compostas somente por textos, senão total, basicamente verbais.

A logomarca Santander é composta por um fundo vermelho e o nome e símbolo em branco. Essas características adentram as propagandas e passam a representar 0 banco. Nas propagandas abaixo, observamos um aumento gradativo de vermelho nas peças $\mathrm{P} 16, \mathrm{P} 17$ e $\mathrm{P} 18$, chegando à totalidade da página em vermelho com texto verbal em branco. Essa tendência foi observada nas propagandas de 2018 tendo continuidade no primeiro semestre de 2019, inclusive nas propagandas televisivas. Isso pode ser justificado pela descrição a seguir extraída do website do banco ${ }^{22}$ :

Em 2004, o Santander iniciou um processo de unificação de marcas que o levou a consolidar todas as que existiam até então em uma única e inconfundível,

22 Disponível em: <www.santander.com.br>. Acesso em: 13 jun. 2019. 
implantada em todos os países onde o banco opera. O Santander é uma marca única global que transmite uma imagem homogênea e consistente, com um único código de comunicação. Tornando-nos reconhecíveis como Grupo nos mercados perante clientes, acionistas, analistas e a sociedade em geral. Uma gestão muito exigente da identidade corporativa reforça nosso valor no mercado e ajuda 0 Santander a ser um dos primeiros bancos do mundo.

O descritivo acrescenta ainda que "a cor vermelha impregna todos os elementos de comunicação com solidez, energia e determinação".

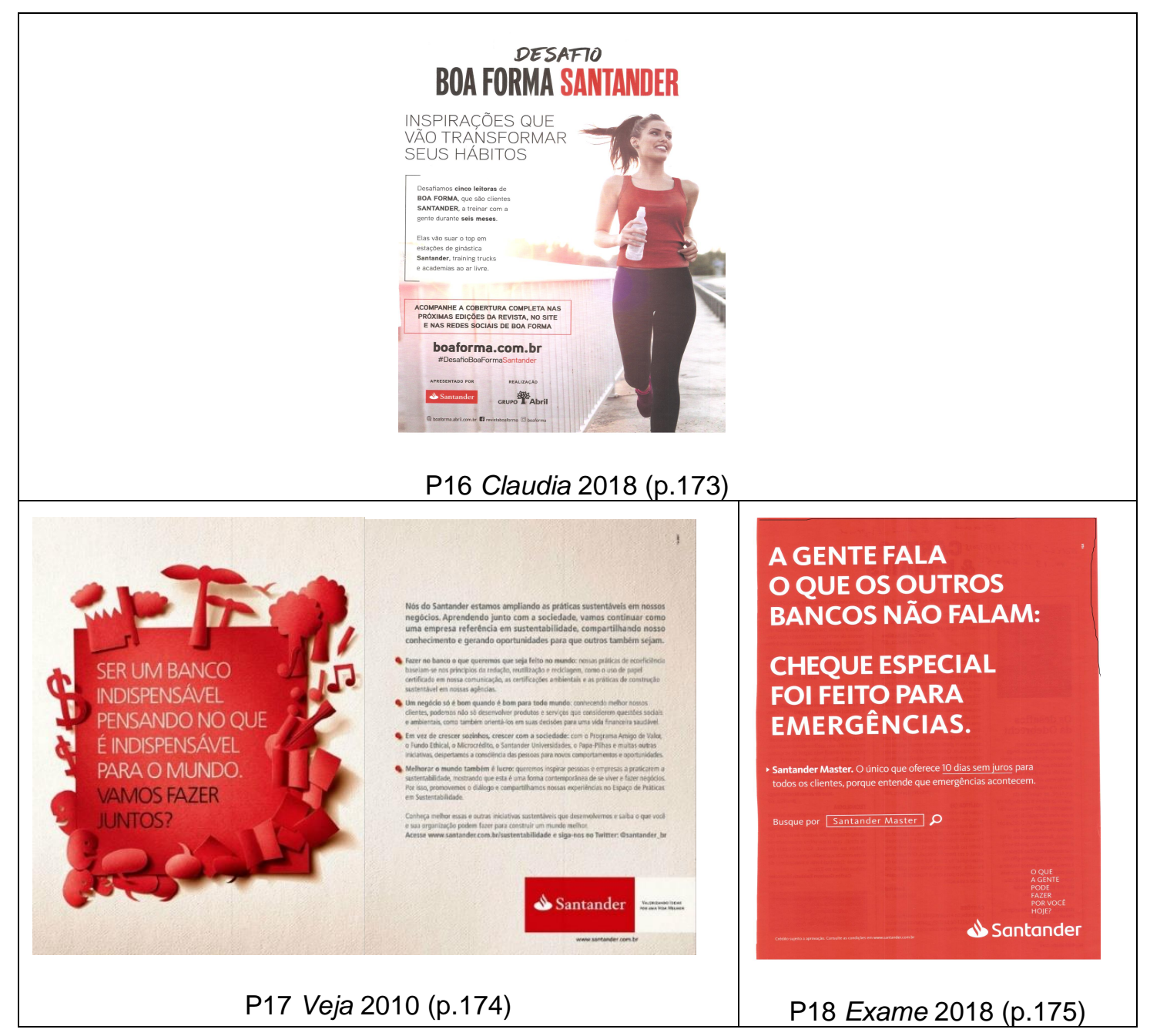

Figura 31 - Propagandas - anos 2010

\subsubsection{Breve contexto histórico do Brasil na década de 2010}


O Brasil inicia os anos 2010 com crescimento econômico de quase $10 \%$, descobertas de petróleo, com o pré-sal, e estabilidade financeira. O país emerge também no mercado internacional. A outra grande novidade da década é que o país elegeu a primeira mulher como presidente da república - Dilma Rousseff. Com ela adentraram à política outras nove mulheres - ministras. Diante dessa realidade, expressões como "empoderamento econômico" e "luta de gênero" ganharam força com tratados, convenções e garantias dos direitos das mulheres.

O cenário das instituições financeiras eleva o Brasil ao reconhecimento internacional de mais avançado no uso das Tecnologias da Informação. A evolução e os investimentos na tecnologia promoveram acessibilidade para milhões de pessoas aos serviços bancários. A Febraban (Federação Brasileira de Bancos) declarou que "a evolução do mercado bancário não teria sido possível sem TI, tornando o banco acessível para milhões de pessoas, em locais remotos e em qualquer horário do dia" (OLIVEIRA, $2015)^{23}$, e da noite, na verdade. Houve um grande salto dos canais digitais e as pessoas passaram a utilizar essa nova forma de fazer transações bancárias e, mais distante e fria vai se tornando a relação banco $\times$ cliente.

Gustavo Fosse, diretor Setorial de Tecnologia Bancária da Febraban, afirmou em 2015 que: "Estamos vivendo a era dos bancos digitais, que cada ano ganham cada vez mais a preferência do consumidor brasileiro" (OLIVEIRA, 2015). Não há dúvida, os brasileiros vivem a era dos bancos digitais e do celular, com o avanço tecnológico, é possível realizar qualquer transação bancária. As idas às agências, a conversa com o gerente e o cafezinho cada vez mais escassos, instauraram o distanciamento entre as instituições financeiras e seu público-alvo.

\subsubsection{Análise das propagandas dos anos 2010}

A P16 é uma propaganda veiculada no exemplar da revista Claudia de março de 2018. Traz uma corredora, identificada no enunciado como representante de leitoras da

${ }^{23}$ Disponível em: <www.santander.com. Acesso em: 14 mar. 2019. 
revista Boa Forma e de clientes do Santander desafiadas a treinar durante seis meses. A propaganda divulga um desafio proposto pelo banco e realizado pelo Grupo Abril, talvez a explicação para a divulgação constar das páginas da revista Claudia, nosso objeto de análise. A peça publicitária não divulga nenhum produto do Santander, mas vincula a imagem do banco a uma ação relacionada à prática de atividade física, boa forma e vida saudável das mulheres clientes, construindo uma imagem institucional positiva do banco que, além de se preocupar com questões "socioambientais" e com "valores éticos e morais", também se preocupa com a qualidade de vida das mulheres - leitoras das revistas femininas.

\begin{tabular}{|c|c|}
\hline 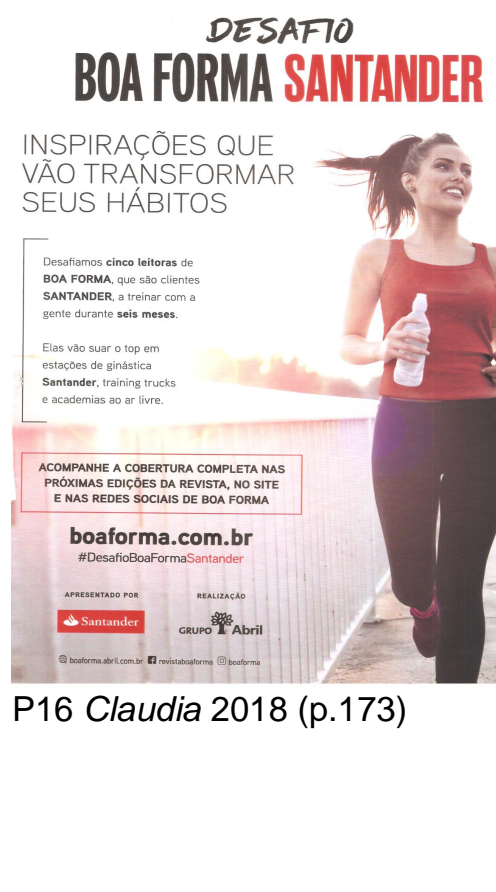 & $\begin{array}{l}\text { DESAFIO } \\
\text { BOA FORMA SANTANDER } \\
\text { INSPIRAÇÕES QUE VÃO TRANSFORMAR SEUS HÁBITOS } \\
\text { Desafiamos cinco leitoras de BOA FORMA, que são clientes } \\
\text { SANTANDER, a treinar com a gente durante seis meses. } \\
\text { Elas vão suar o top em estações de ginástica Santander, training } \\
\text { trucks e academias ao ar livre. }\end{array}$ \\
\hline
\end{tabular}

No que tange à função de representação, observamos a representação narrativa com processo de ação não transacional, pois a ação envolve apenas uma participante (a corredora) e um vetor (orientado pela orientação corporal na atividade da corrida).

Quanto à função de interação, o contato é de oferta, pois não há contato direto do olhar da participante com o leitor, mas, sim, o oferecimento da participante para a contemplação por parte de quem observa - relação impessoal. A captação da participante se dá por um ângulo frontal e plano médio/medium shot, remetendo a uma 
distância de vínculo apenas social. No tocante à perspectiva/atitude, a imagem é proporcionada por um ângulo igualitário entre o leitor e o participante. A modalidade tem um valor de realidade naturalista.

Em relação à função de composição, no lado esquerdo da página multimodal, encontra-se a informação nova e, no lado direito, o dado/conhecido, portanto, podemos perceber o valor informacional de dado $\times$ novo invertido.

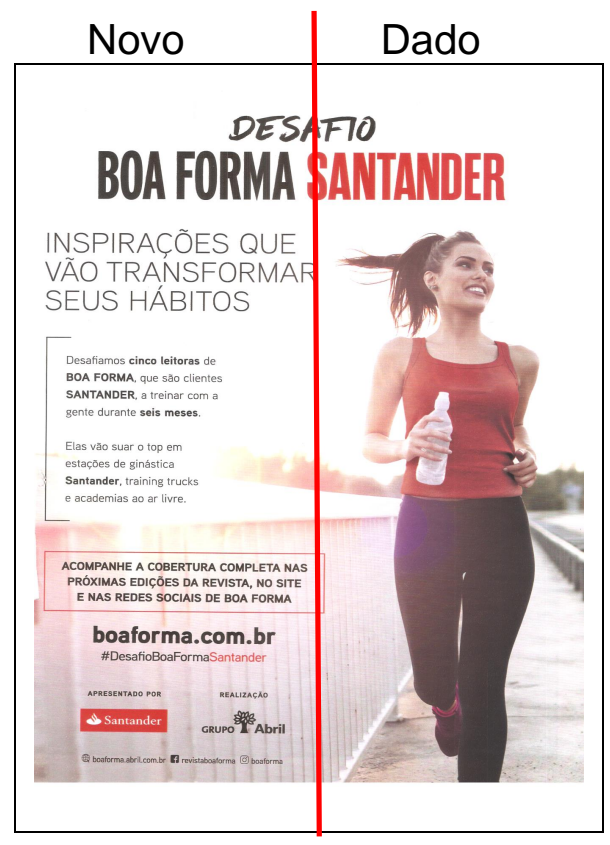

Claudia 2018 (p.173)

Enunciador e coenunciador, momento e lugar da enunciação estão claramente definidos na situação de enunciação de P16. O enunciador aparece a partir do verbo "desafiamos" que remete ao embreante "nós". "Acompanhe" é uma marca de interpelação do coenunciador que exemplifica o plano embreado de enunciação e mostra que o enunciador "realiza uma enunciação que visa a atuar diretamente sobre o coenunciador por força da própria enunciação", de acordo com Maingueneau (2013, p. 129). O embreante "a gente" remete ao enunciador - anunciante - e apresenta uma generalização, convidando a leitora a integrar uma equipe/grupo, no qual o enunciador está incluído. 
O valor atitudinal de afeto pode ser constatado a partir seleção do léxico "inspirações", se tomarmos os sentidos - conselho, sugestão, influência, do anunciante para com a leitora. A expressão pode ter valor de conselho positivo, influência positiva que vai "transformar os hábitos" da mulher para que tenha "vida saudável", "qualidade de vida", "boa forma física". O enunciado "elas vão suar o top" tem igual valor de afeto, pois "elas vão suar", figurativamente, significa elas têm garra, elas vão se esforçar, elas são guerreiras; "o top", por ser uma vestimenta feminina ou própria da mulher: "elas vão lutar sem perder a feminilidade". É a instituição financeira se colocando lado a lado com a leitora para ajudá-la a transformar seus hábitos, sua vida. O Banco se identificando com a cliente para merecer sua confiança.

A P17, a seguir, veiculada na revista Veja de maio de 2010, é de página dupla, trazendo do lado esquerdo a mensagem: "Ser um banco indispensável pensando no que é indispensável para o mundo. Vamos fazer juntos?", destacada em uma placa vermelha cercada por representações de árvores, pássaros, lápis, notas musicais, símbolo de dinheiro, nuvem, livro, indústria, balões de diálogo, carinhas conversando. Na página da direita, um longo enunciado que corrobora a mensagem de práticas sustentáveis propostas pelo Santander.

Observamos que a P17 e a P16, desta década, mantêm a proposta das propagandas da década de 2000: valores socioambientais, práticas saudáveis, sustentabilidade. 


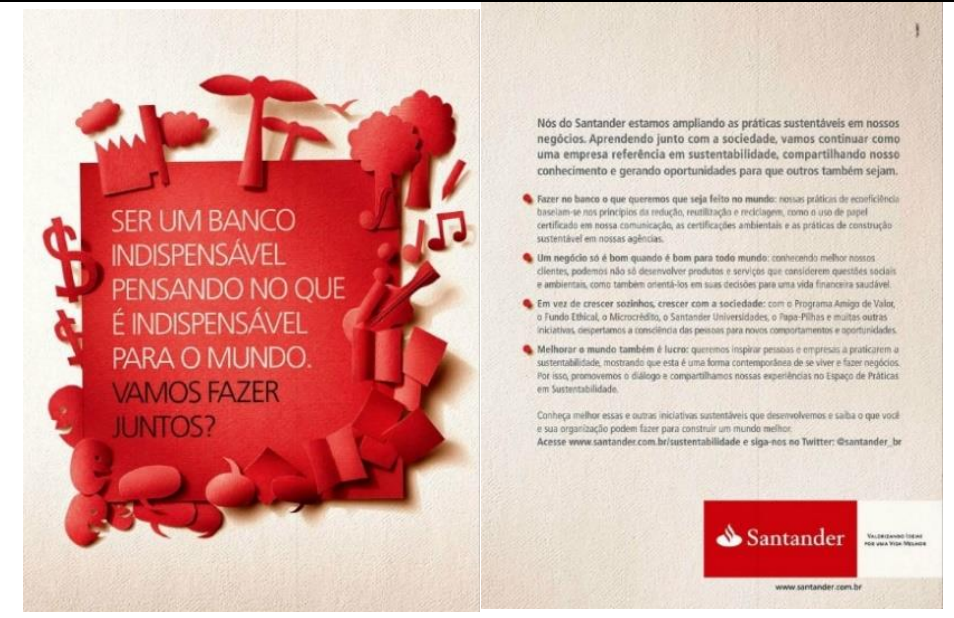

P17 Veja 2010 (p.174)

\section{SER UM BANCO INDISPENSÁVEL PENSANDO NO QUE É INDISPENSÁVEL PARA O MUNDO. VAMOS FAZER JUNTOS?}

Nós do Santander estamos ampliando as práticas sustentáveis em nossos negócios. Aprendendo junto com a sociedade, vamos continuar como uma empresa referência em sustentabilidade, compartilhando nosso conhecimento e gerando oportunidades para que outros também sejam.

- Fazer no banco o que queremos que seja feito no mundo: nossas práticas de ecoeficiência baseiam-se nos princípios de redução, reutilização e reciclagem, como o uso de papel certificado em nossa comunicação, as certificações ambientais e as práticas de construção sustentável em nossas agências.

- Um negócio só é bom quando é bom para todo mundo: conhecendo melhor nossos clientes, podemos não só desenvolver produtos e serviços que considerem questões sociais e ambientais, como também orientálos em suas decisões para uma vida financeira saudável.

- Em vez de crescer sozinhos, crescer com a sociedade: com o Programa Amigo de Valor, o Fundo Ethical, o Microcrédito, o Santander Universidades, o Papa-Pilhas e muitas outras iniciativas, despertamos a consciência das pessoas para novos comportamentos e oportunidades.

- Melhorar o mundo também é lucro: queremos inspirar pessoas e empresas a praticarem a sustentabilidade, mostrando que esta é uma forma contemporânea de se viver e fazer negócios. Por isso, promovemos o diálogo e compartilhamos nossas experiências no Espaço de Práticas em Sustentabilidade.

Conheça melhor essas e outras iniciativas sustentáveis que desenvolvemos e saiba o que você e sua organização podem fazer para construir um mundo melhor.

Acesse www.santander.com.br/sustentabilidade e siga-nos no Twitter: @santander.br

Santander

No que se refere à função de representação na imagem de $\mathrm{P} 17$, observamos a representação conceitual por processos classificatórios, identificada pelos objetos distribuídos em torno da placa vermelha (página da esquerda) como pertencentes a uma determinada categoria (práticas sustentáveis) de forma implícita, posto que não há legenda verbal orientando a respeito do que se trata. No entanto, notamos também a representação conceitual por processos analíticos, pois os elementos representados foram dispostos em uma relação de parte/todo, por exemplo, as árvores representam o 
reflorestamento; o lápis e o livro representam a educação e a preservação da natureza; a indústria não poluente representa a qualidade de vida das pessoas; o cifrão representa economia de dinheiro ou lucros; os balões de fala representam o diálogo ou o compartilhar experiências/conhecimentos.

Passamos à função de composição, dadas as especificidades de P17, que dispensa a análise da função de interação. Quanto à organização dos elementos representados na imagem analisada conforme o espaço que ocupam na página multimodal, o valor da informação ocorre por meio do dado $\times$ novo. O dado é a imagem conhecida do leitor: as práticas sustentáveis são indispensáveis para o mundo e precisam ser realizadas coletivamente, isto é, todos "juntos". O novo é o enunciado da página da direita em que o Santander elenca, como em uma lista de prioridades, como ampliar as práticas sustentáveis nos negócios, declara-se como uma empresa de referência em sustentabilidade e se coloca à disposição para compartilhar seus conhecimentos para que outros também sejam referência nesse quesito, como podemos perceber nos enunciados a seguir:

- Fazer no banco o que queremos que seja feito no mundo [...]

- Um negócio só é bom quando é bom para todo mundo [...]

- Em vez de crescer sozinhos, crescer com a sociedade [...]

- Melhorar o mundo também é lucro: queremos inspirar pessoas a praticarem a sustentabilidade

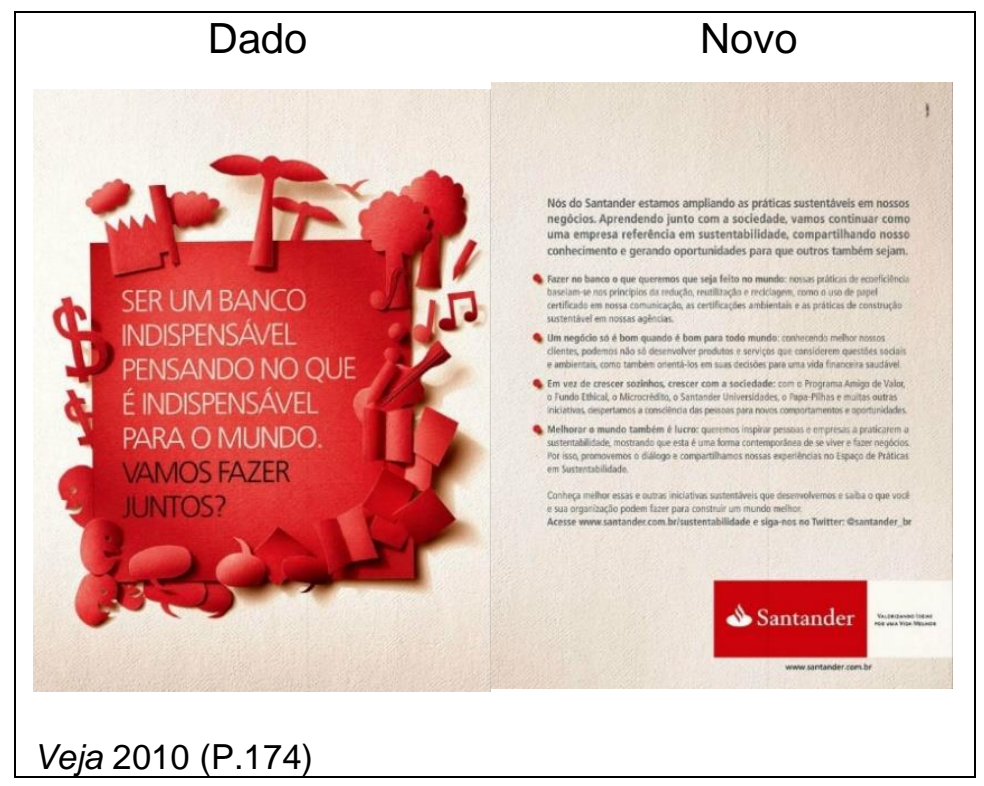


Quanto ao enquadramento, percebemos que os elementos que compõem a imagem são representados por meio de uma interligação, constituindo uma grande mancha vermelha. A imagem sugere que os elementos não devem ser vistos como informações separadas, mas, sim, interligados e juntos compõem a mensagem visual.

A saliência se dá pelo tamanho e volume da mancha vermelha e pela intensidade da cor vermelha.

Na página da direita, o enunciado destaca o enunciador, assim:

- Nós do Santander estamos ampliando as práticas sustentáveis em nossos negócios.

Num trecho de quatro linhas localizamos os embreantes pronominais "nós", "nossos" e "nosso" e os embreantes verbais "estamos aprendendo", "vamos", "compartilhando" e "gerando". O coenunciador aparece representado pelos termos: "outros", "todo mundo", "nossos clientes", "suas", "pessoas", "você" e pelos verbos "conheça", "saiba" e "acesse".

O anunciante se autodenomina "indispensável" na vida do leitor porque tem a humildade de "aprender junto com a sociedade" e por ter se tornado "uma empresa referência em sustentabilidade", que quer compartilhar seus conhecimentos:

- Vamos fazer juntos?

O enunciado "queremos inspirar pessoas e empresas a praticarem sustentabilidade" suscita o valor atitudinal de afeto para com o leitor, a quem o anunciante deseja exercer influência para que ele assuma práticas sustentáveis, que lhe trarão felicidade e satisfação pela oportunidade de também, em conjunto com o Santander, "melhorar o mundo". É o banco buscando identificação de valores éticos com seu cliente.

A P18 é a terceira peça publicitária dos anos 2010 e última a ser analisada nesta pesquisa. Como já mencionado, a imagem é composta por um fundo vermelho intenso e letras brancas de tamanhos variados, dependendo do destaque que se pretende dar a elas. 


\begin{tabular}{|c|c|}
\hline 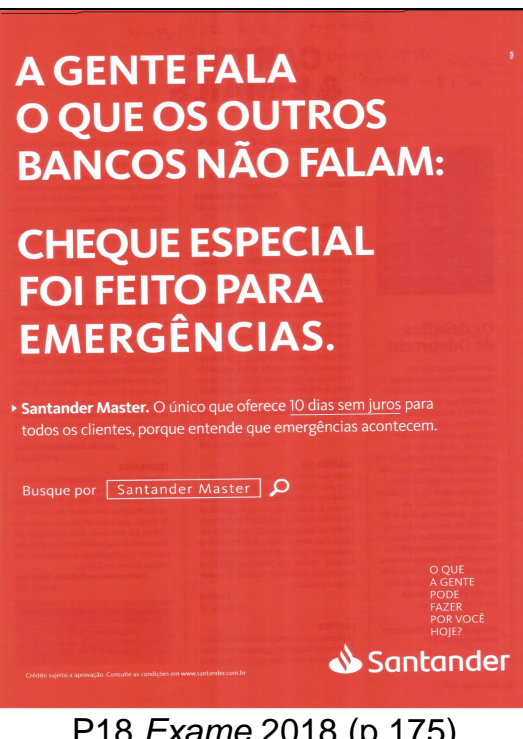 & $\begin{array}{l}\text { A GENTE FALA O QUE OUTROS BANCOS } \\
\text { NÃO FALAM: } \\
\text { CHEQUE ESPECIAL FOI FEITO PARA } \\
\text { EMERGÊNCIAS. } \\
\text { Santander Master. O único que oferece } \underline{10 \text { dias }} \\
\text { sem juros para todos os clientes, porque entende } \\
\text { que emergências acontecem. } \\
\text { Busque por Santander Master } \\
\text { O que a gente pode fazer por você hoje? }\end{array}$ \\
\hline
\end{tabular}

Quanto à análise da linguagem visual em P18, iremos nos restringir a um dos aspectos da função composicional - o valor de informação - que observamos se tratar do dueto ideal x real, em que a informação ideal corresponde à declaração do anunciante: - A gente fala o que os outros não falam:

E a informação real corresponde a um questionamento do anunciante ao leitor:

- O que a gente pode fazer por você hoje?

Na sequência, a logomarca do banco é descrita da seguinte forma: "a chama é um símbolo que evoca o 'S' da inicial do 'Santander' e transmite triunfo, liderança, lucidez e dinamismo. O logotipo é a palavra 'Santander', o nome que representa o Banco e reflete sua origem e trajetória". ${ }^{24}$

${ }^{24}$ Disponível em: <www.santander.com. Acesso em: 14 mar. 2019. 


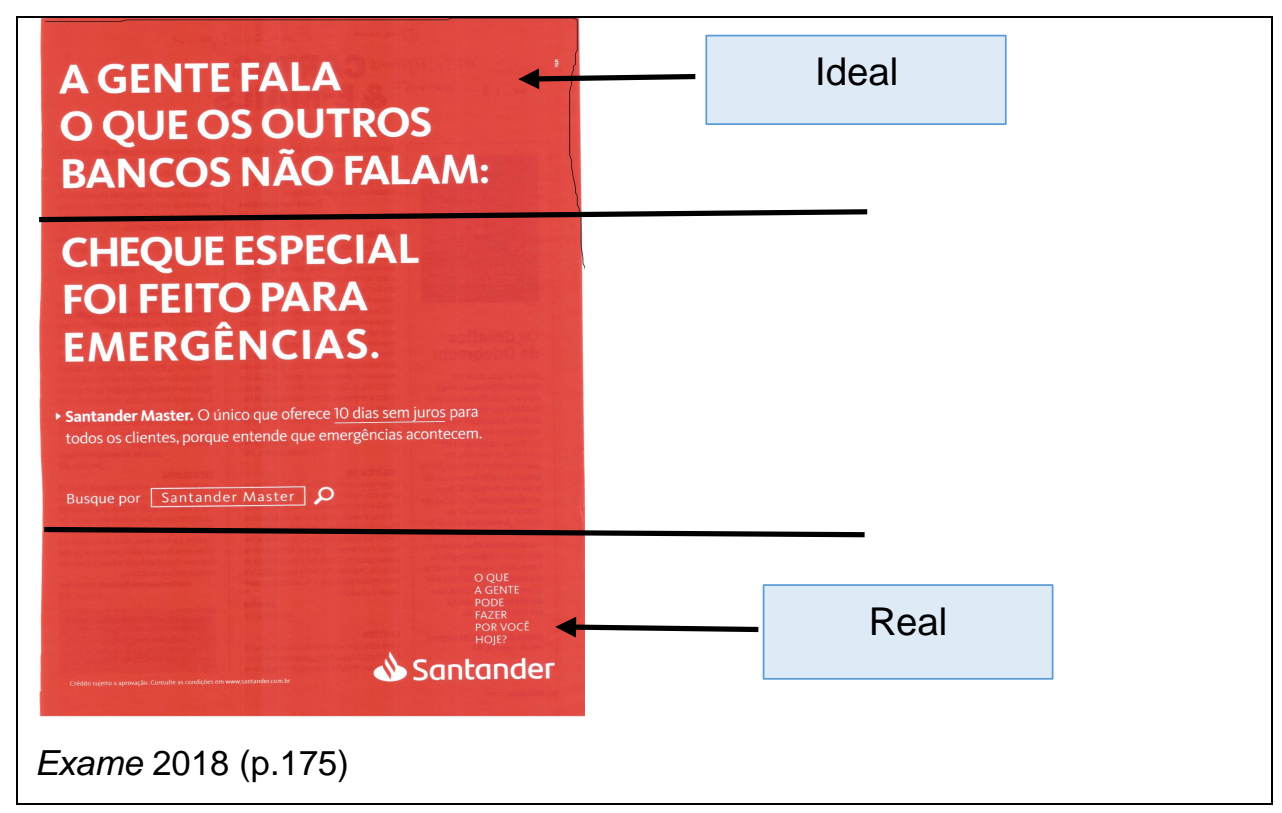

Quanto à análise dos aspectos linguísticos, o enunciado do topo da página invoca a curiosidade do leitor quanto ao que vai falar o anunciante, que os outros bancos não falam? Na sequência vem a resposta:

- Cheque especial foi feito para emergências.

Essa ação do anunciante de "falar o que os outros não falam" remete à transparência, à atitude de afeto: de lealdade, de quem não engana o seu público-alvo, aproximando o leitor, gerando confiabilidade. E, ainda na sequência, o banco afirma oferecer dez dias sem juros, porque entende que "emergências acontecem", ou seja, compreende o cliente, partilha de suas necessidades e identifica-se com ele. Nessa ação de conceder 10 dias sem juros ocorre uma atitude de julgamento de sansão social, em que a instituição financeira - Banco Santander -, envolto num momento histórico de bancos digitais e do avanço tecnológico que distancia o anunciante do leitor, assume o comportamento de justiça para com seu público-alvo, concedendo a ele "10 dias sem juros" no uso de seu limite bancário. Isso remete a uma maior aproximação do leitor que sente receber garantias e segurança por parte do anunciante - Banco Santander.

Percebemos ao longo das análises que a seleção feita das imagens incorpora em sua grande maioria as pessoas, sejam reais ou representadas; as representações 
narrativas se marcam nas peças analisadas; o contato de demanda em algumas imagens; a disposição das informações (ideal $x$ real/dado $x$ novo/central $x$ marginal) destacando sempre as mais relevantes ao leitor; a demarcação da posição do enunciador e do coenunciador; enfim, todos esses dados comprovam um cuidado e preocupação em explorar dessa comunicação tão eficaz (propagandas impressas em revistas) vantagens e aproximação entre os atores sociais envolvidos. A interação de média distância constatada na grande maioria das propagandas nos remete e atribuir como próprias dessa modalidade de relacionamento: empresa $x$ cliente, ou seja, o médio distanciamento, nesse caso justifica-se por envolver um relacionamento comercial.

A partir das análises, não encontramos dados que remetam à hipótese de frieza no relacionamento dos anunciantes - instituições financeiras - e os leitores das revistas selecionadas. Pelo contrário, observamos a valorização de recursos multimodais que remetem a atitudes de afeto e apreciação, marcando a identificação e aproximação, o que iremos esmiuçar nas nossas considerações finais. 


\section{CONSIDERAÇÕES FINAIS}

O desejo de contribuir para o aprofundamento das análises de propagandas de instituições financeiras publicadas em revistas impressas e entender a construção da imagem a partir dos discursos dessas instituições pertencentes a uma área do mercado de tanta objetividade e lógica (economia e finanças), tão opostamente veiculados em um gênero discursivo multimodal marcado pela sedução, encantamento e tantas simbologias (a propaganda), motivou-nos a esta pesquisa.

Lançamo-nos à busca pelo corpus (no meio físico e virtual) e visualizamos uma instituição que se mantém perene, apesar das mudanças em sua marca - Banco da Lavoura/Banco Real/Banco Santander, que veicula suas propagandas no meio midiático impresso direcionado a públicos pertencentes aos diversos segmentos da sociedade público geral, público feminino e público executivo - há muito tempo. Determinamos, então, o nosso recorte: propagandas da marca sequencial Banco da Lavoura/Banco Real/Banco Santander, veiculadas nas revistas Claudia, Veja e Exame, da década de 1960 até 2018.

Para cumprir tal tarefa, constatamos a necessidade de pinçar categorias, sistemas e teorias que dessem sustentação a essa empreitada. Deparamo-nos com as categorias da gramática do design visual, a partir dos pressupostos de Kress e Van Leeuwen (2006); com o sistema da valoração (ou avaliatividade) atitudinal, de Martin \& White (2005); com as teorias sobre a linguagem e o discurso da propaganda de Sandmann (2012); com a construção de imagem e seus recursos argumentativos de Amossy (2018) e a cena enunciativa de Maingueneau (2013), dentre outros. Previmos na metodologia uma pesquisa sócio-histórica-econômica que contemplasse as seis décadas selecionadas contando com autores como Brandão (1995) e Fausto (2006).

A partir das análises realizadas, constatamos que a mídia desempenha relevante papel de ampliar visões e diminuir distâncias, transformando o individual em coletivo, participando ativamente da construção do imaginário social (GREGOLIN, 2003). No interior das diversas mídias, encontramos as revistas impressas, que, apesar do tempo 
e da evolução tecnológica, trouxeram agilidade à notícia e às informações, continuam sendo atrativas para os indivíduos e para a sociedade, pois fazem parte do processo histórico e social do país e da produção de sentidos para as pessoas.

As propagandas, por sua vez, corroboram as prerrogativas das revistas e acrescentam ao seu papel a difícil tarefa de persuadir, convencer e levar à ação pela palavra, muitas vezes, pela provocação e pelo choque do leitor (SANDMANN, 2012). A propaganda veicula ideologias, que se transformam no decorrer do tempo e da história, assim como os valores da sociedade. Essas ideologias se marcam nas propagandas, às vezes, pela simples busca de sintonia dos anunciantes com os valores do público-alvo ou daquele período e pela promoção de visões de mundo que representam ideologias.

As propagandas veiculam enunciados, portanto consistem em situações enunciativas que trazem marcas linguísticas de pessoas "eu" e "você" enunciador/anunciante e coenunciador/leitor - e de tempo e espaço "agora" e "aqui". Nesse contexto, o anunciante, no papel de enunciador, ocupa diversos papéis que abrangem desde aquele que constrói a enunciação, visando a atuar diretamente sobre o coenunciador - o leitor, até aquele que emite posicionamentos e juízos de valores modais (MAINGUENEAU, 2013), como constatamos em exemplos do corpus, que remeteram à construção de imagem positiva das instituições financeiras.

Além de enunciados, as propagandas veiculam imagens, desenhos, gráficos, cores, formatos, símbolos e representações, que reproduzem verdadeiras imagens da realidade e dos interesses de instituições sociais, sendo, novamente, ideológicas (KRESS, VAN LEEUWEN, 2006). A gramática do design visual subsidia as análises dos textos multimodais das propagandas oferecendo categorias e modalidades de indiscutível relevância para a nossa pesquisa. Em todas as peças, foi possível identificar que as imagens não são dispostas indistintamente, pelo contrário, elas corroboram a mensagem verbal, que é de informação e esclarecimento ao leitor, mas também de cuidado e atenção.

Com relação ao público-alvo de cada uma das publicações selecionadas, nota-se uma preocupação personalizada para aquele público específico, tomamos como base, por exemplo, a mulher leitora. As seis propagandas veiculadas na revista Claudia - 
analisadas nesta tese - direcionam-se especificamente à mulher que, primeiro, sonha em adquirir bens e tem a garantia e segurança de grandes bancos que poderão tornar possível a sua conquista (década de 1960); dez anos depois, já dona da própria contacorrente, recebe uma descrição passo a passo do funcionamento de seu extrato, que assim como ela é "bonito e inteligente" e "de aparência elegante". O anunciante, parecendo ler suas necessidades, leva a mulher da classe média urbana a uma maior independência e autonomia a partir do domínio das informações contidas no seu extrato de conta-corrente (década de 1970). Na década seguinte (1980), a mulher recebe, como em um gênero textual/discursivo bastante comum ao universo feminino, "receitas" de produtos e investimentos que podem aumentar o seu tempo de lazer para maior dedicação a quem ela gosta.

$\mathrm{Na}$ propaganda da década de 1990, a mulher vê seus atributos valorizados "intuição e bom senso" e, com os produtos de qualidade do Banco, ela terá uma virada de ano cheia de vantagens e um ano novo próspero nos negócios. Na próxima propaganda analisada, o anunciante, almejando ser o banco da vida de seus clientes, declara-se à mulher leitora "queremos ser o banco da sua vida", convidando-a a construir "juntos" um banco melhor, um país melhor a partir de práticas socioambientais (década de 2000). E, na última peça, diante da realidade do "empoderamento econômico", o anunciante procura tocar a leitora com uma inspiração para transformação de hábitos que garantirão boa forma física e qualidade de vida da leitora que "que não sonha, consome". As propagandas das instituições financeiras ora analisadas, evoluíram "para acompanhar as mudanças do perfil desse público" - a mulher.

Esse tratamento personalizado - de média proximidade, de poder de igualdade e relação de nível social - criado a partir da leitura das estruturas visuais das propagandas veiculadas em Claudia se repete igualmente nos textos multimodais criados para os dois outros públicos - geral e executivo - das revistas Veja e Exame, contemplando dois de nossos problemas da pesquisa: a seleção dos recursos multimodais - verbais e visuais - e o perfil do público-alvo para quem são construídas as propagandas que interferem na construção da imagem de aproximação/identificação das instituições financeiras nas publicações impressas. 
Semelhante resultado foi obtido nas análises da categoria atitudinal do sistema de valoração ou avaliatividade (MARTIN, WHITE, 2004, 2005). Apesar da constatação de um ou outro domínio semântico comportamental ou estético, a grande representação coube à emoção. Atitudes valorativas de afeto permearam quase a totalidade dos enunciados das propagandas analisadas: "gostamos de investidores desconfiados", "bonito e inteligente", "aparência elegante", "pessoas privilegiadas", "você não se preocupa mais", "para você e para quem você gosta", "seus amigos vão adorar a sua casa nova", "para que cansar a sua beleza", "intuição e bom senso", "voltaram a ter aquele ar de felicidade".

Os exemplos em que observamos valor de apreciação são de apreciação positiva e ocorreram em casos em que as instituições financeiras se apresentam como "grandes bancos", "poderosas organizações", "é esta organização que vai oferecer a supergarantia que você exige", e ainda em "pois só assim poderemos construir juntos um banco melhor, um país melhor". Em uma das últimas peças analisadas, o valor de apreciação invertese do anunciante para o público-alvo, como os exemplos anteriores, do valor de apreciação do público-alvo para o anunciante: "o banco da minha vida", que "valoriza o meu potencial" e, principalmente, que "tem a ver com os meus valores".

As ocorrências de valor de julgamento tanto de estima social: "com uma simples ordem sua o Banco Real paga automaticamente e no prazo" quanto de sanção social: sua empresa "pode ter isenção total de tarifas e redução de juros", são positivas e beneficiam a pessoa - o leitor. Valores morais, éticos e socioambientais são bastante tocados nas propagandas dos anos 2000 e 2010, ratificando a imagem positiva que as instituições financeiras pretendem construir de si nas propagandas de revistas impressas.

Entendemos que o contexto sócio-histórico-econômico influencia a seleção de recursos para a construção da imagem das instituições financeiras, na medida em que as tecnologias vão evoluindo, as redes sociais vão tomando conta das relações entre as pessoas, e assim o distanciamento físico entre o anunciante e o leitor se torna inevitável. As propagandas têm de ser mais efetivas, mais ousadas, mais agressivas, mais investidas de recursos persuasivos, pois passam a exercer o importante papel de encurtar a distância e criar aproximação/identificação entre o anunciante e o público-alvo, 
podendo chegar a um contato de extrema proximidade: "o que a gente pode fazer por você hoje?".

Respondendo a nosso último e, talvez, mais importante questionamento: a imagem de si que as instituições pretendem construir nas propagandas das revistas impressas é de identificação com os valores dos seus clientes a partir de quesitos como segurança, credibilidade, pioneirismo, confiança e transparência "a gente fala o que os outros bancos não falam" - Santander. 


\section{REFERÊNCIAS}

AMOSSY, Ruth. Imagens de si no discurso: a construção do ethos. 2. ed. São Paulo: Contexto, 2018a.

. Argumentação no discurso. São Paulo: Contexto, 2018b.

ANDRADE, Carlos Drummond de. Anúncios. Jornal do Brasil, 16 out.1971.

BONIFÁCIO, Carla Alecsandra de Melo. A tradição discursiva e a gramática do design visual no anúncio publicitário. Dissertação (Doutorado em Linguística) Centro de Ciências Humanas, Letras e Artes (CCHLA), Universidade Federal da Paraíba. João Pessoa, 2011. DOI: <https://repositorio.ufpb.br/handle/tede/6344>.

BRANDÃO, Ignácio Loyola. Itaú 50 anos. São Paulo: DBA, 1995.

CARMO, Claudio Márcio do. Um olhar antropológico sobre a gramática do design visual: criando um espaço de intersecção com a antropologia do movimento. In: ALMEIDA, Danielle Barbosa Lins de (Org.). Novas perspectivas em análise visual do texto ao contexto. São Paulo; Campinas: Mercado de Letras, 2016.

CAMPOS, Raquel Discini de. Mulheres e crianças na imprensa paulista. São Paulo: Unesp, 2009.

CHARAUDEAU, Patrick. Discurso das mídias. São Paulo: Contexto, 2010. . Linguagem e discurso: modos de organização. São Paulo: Contexto, 2014.

CHILDS, Harwod L. Relações públicas, propaganda e opinião pública. Rio de Janeiro: FGV, 1967.

CISNE, Mirla. Feminismo e consciência de classe no Brasil. São Paulo: Cortez, 2014.

COSTA, Maria Paula. Revista Claudia: imagens femininas na moderna sociedade brasileira (1961-1985). ANPUH - XXIII SIMPÓSIO NACIONAL DE HISTÓRIA.

Londrina, 2005. Disponível em: <http://anais.anpuh.org/wp-

content/uploads/mp/pdf/ANPUH.S23.1416.pdf>. Acesso em: 13 fev. 2017.

DIONÍSIO, Angela Paiva. Gêneros multimodais e multiletramento. In: KARWOSKI, Acir Mario; GAYDECZKA, Beatriz BRITO; Karim Siebeneicher (Org.) Gêneros textuais: reflexões e ensino. Palmas; União da Vitória: Kaygangue, 2005.

DONDIS, Donis A. Sintaxe da linguagem visual. 2. ed. São Paulo: Martins Fontes, 1997. 
FAUSTO, Boris. História do Brasil. 12. ed. São Paulo: Edusp, 2006.

FÁVERO, Leonor Lopes; KOCH, Ingedore F. Villaça. Linguística textual: introdução. 4. ed. São Paulo: Cortez, 1998.

FUZER, Cristiane; CABRAL, Sara Regina Scotta. Introdução à gramática sistemicofuncional em língua portuguesa. Campinas: Mercado de Letras, 2014.

GARCIA, Nelson Jahr. O que é propaganda ideológica. São Paulo: Brasiliense, 1982.

GONÇALVES SEGUNDO, Paulo Roberto. Tradição, dinamicidade e estabilidade nas práticas discursivas: um estudo da negociação intersubjetiva na imprensa paulistana. Tese (Doutorado) - Faculdade de Filosofia, Letras e Ciências Humanas - Universidade de São Paulo, São Paulo, 2011.

, Paulo Roberto. Linguística sistêmico-funcional e análise crítica do discurso:

explorando convergências e explicitando especificidades. Estudos Linguísticos, v. 43 (3), p. 1282-1297, set./dez. 2014.

GOUVEIA, Carlos A. M. Texto e gramática: uma introdução à Linguística SistêmicoFuncional. Matraga, v. 16, n. 24, Rio de Janeiro, p. 13-47, jan./jun. 2009.

GREGOLIN, Maria do Rosário (Org.). Discurso e mídia: a cultura do espetáculo. São Carlos: Claraluz, 2003.

GUIMARÃES, Elisa. A articulação do texto. 7.ed. São Paulo: Ática, 1999.

HALLIDAY, Michael. Language as social semiotic: the social interpretation of language and meaning. London: Edward Arnold, 1978.

; MATTHIESSEN, Christian. Introduction to functional grammar. 3. ed.

London: Hodder Arnold, 2004.

HOUAISS, Instituto Antônio. Dicionário Houaiss eletrônico da língua portuguesa.

Rio de Janeiro: Objetiva, 2009.

IASBECK, Luiz Carlos Assis. A arte dos slogans: as técnicas de construção das frases de efeito no texto publicitário. São Paulo: Annablume, 2002.

JAGUARIBE, Helio. Brasil: dilemas e desafios. Estudos Avançados, São Paulo, v. 14, n. 38, jan./abr. 2000.

KERSCH, Dorotea; COSCARELLI, Carla Viana; CANI, Josiane Brunetti (Org.).

Multiletramentos e multimodalidade: ações pedagógicas aplicadas a linguagem.

Campinas: Pontes, 2016. 
KRESS, Gunther; VAN LEEUWEN, Theo. Reading images: the grammar of visual design. 2. ed. London: Routledge, 2006.

MAINGUENEAU, Dominique. Análise de textos de comunicação. Trad. Maria Cecília P. de Souza-e-Silva e Décio Rocha. 6. ed. São Paulo: Cortez, 2013.

MARTIN, James Robert; WHITE, Peter Robert Rupert. The language of evaluation: appraisal in English. New York: Palgrave MacMillan, 2005.

MEYER, Michel. Questões de retórica: linguagem, razão, sedução. Trad. Antonio Hall. Lisboa: Edições 70, 2014.

MOSCA, Lineide do Lago Salvador (Org.). Velhas e novas retóricas: convergências e desdobramentos. Retóricas de ontem e de hoje. 2. ed. São Paulo: Humanitas FFLCH/USP, 2001.

MOTTA, Ana Raquel; SALGADO, Luciana (Org.). Ethos discursivo. 2. ed. São Paulo: Contexto, 2015.

MUNIZ, Eloá. Publicidade e propaganda: origens históricas. Caderno Universitário, n. 148. Canoas: Ulbra, 2004.

NASCIMENTO, Roseli Gonçalves; BEZERRA, Fábio Alexandre; HEBERLE, Viviane Maria. Multiletramentos: iniciação à análise de imagens. Análise \& ensino. Pelotas, v.14, n.2, p.529-552, jul./dez.2011.

PAES DE BARROS, Claudia Graziano. Capacidades de leitura de textos multimodais. Polifonia, EDUFMT, Cuiabá, n. 19, p. 161-186, 2009. DOI:

$<$ https://www1.ufmt.br/ufmt/unidade/userfiles/publicacoes/da1fb711700d927dbf8296e04 64aeb96.pdf>.

QUEIROZ, Adolpho. Uma sinopse da propaganda brasileira. In: QUEIROZ, Adopho (Org.). No espaço cênico da propaganda política: mídia, comunicação e marketing político nas campanhas presidenciais brasileiras. Taubaté: Papel Brasil, 2011.

RAMOS, Cleonice Men da Silva. Ethos da revista Exame e labirintos dos gêneros constituintes. 2006. Dissertação (Mestrado em Semiótica e Linguística Geral) Universidade de São Paulo, São Paulo, 2006.

RIBEIRO, Ana Elisa. Textos multimodais: leitura e produção. São Paulo: Parábola, 2016.

ROJO, Roxane. Textos multimodais. Campinas: Unicamp, s/d.

ROSSINI, Naiane Neves; TASSIANE, Taisa Pivetta; OLIVEIRA FILHA, Elza Aparecida de. Análise da publicidade na revista Claudia. XII Congresso de Ciências da Comunicação na Região Sul. Londrina, PR, 2011. 
SANDMANN, Antonio. A linguagem da propaganda. São Paulo: Contexto, 2012.

SANTANDER no Brasil. Disponível em: <www.santander.com.br/institucionalsantander/santander-no-brasil>. Acesso em: 31 jul. 2018.

SANT'ANNA, Armando. Propaganda. São Paulo: Pioneira, 1981.

SEGATTO, Lisane Schafer; KNOLL, Graziela Frainer. Análise dos recursos multimodais em texto publicitário impresso. Signo, Santa Cruz do Sul, v. 38, n. 64, p. 66-83, jan./jun. 2013. Disponível em: <http://online.unisc.br/seer/index.php/signo>. Acesso em: 30 nov. 2016.

VAN DIJK, Teun A. Discurso e contexto: uma abordagem sociocognitiva. Trad. Rodolfo llari. São Paulo: Contexto, 2012. . Discurso e poder. São Paulo: Contexto, 2015.

WOLF, Mauro. Teorias das comunicações de massa. 4. ed. São Paulo: Martins Fontes, 2009.

WHITE, Peter. Valoração: a linguagem da avaliação e da perspectiva. Linguagem em (Dis)curso. Tubarão, v. 4, n. esp., p. 178-205, 2004. 
ANEXOS 


\section{ANEXO A - Corpus}

P1 Banco da Lavoura-Claudia, ago. 1962, ano II, n. 11, p. 86-87

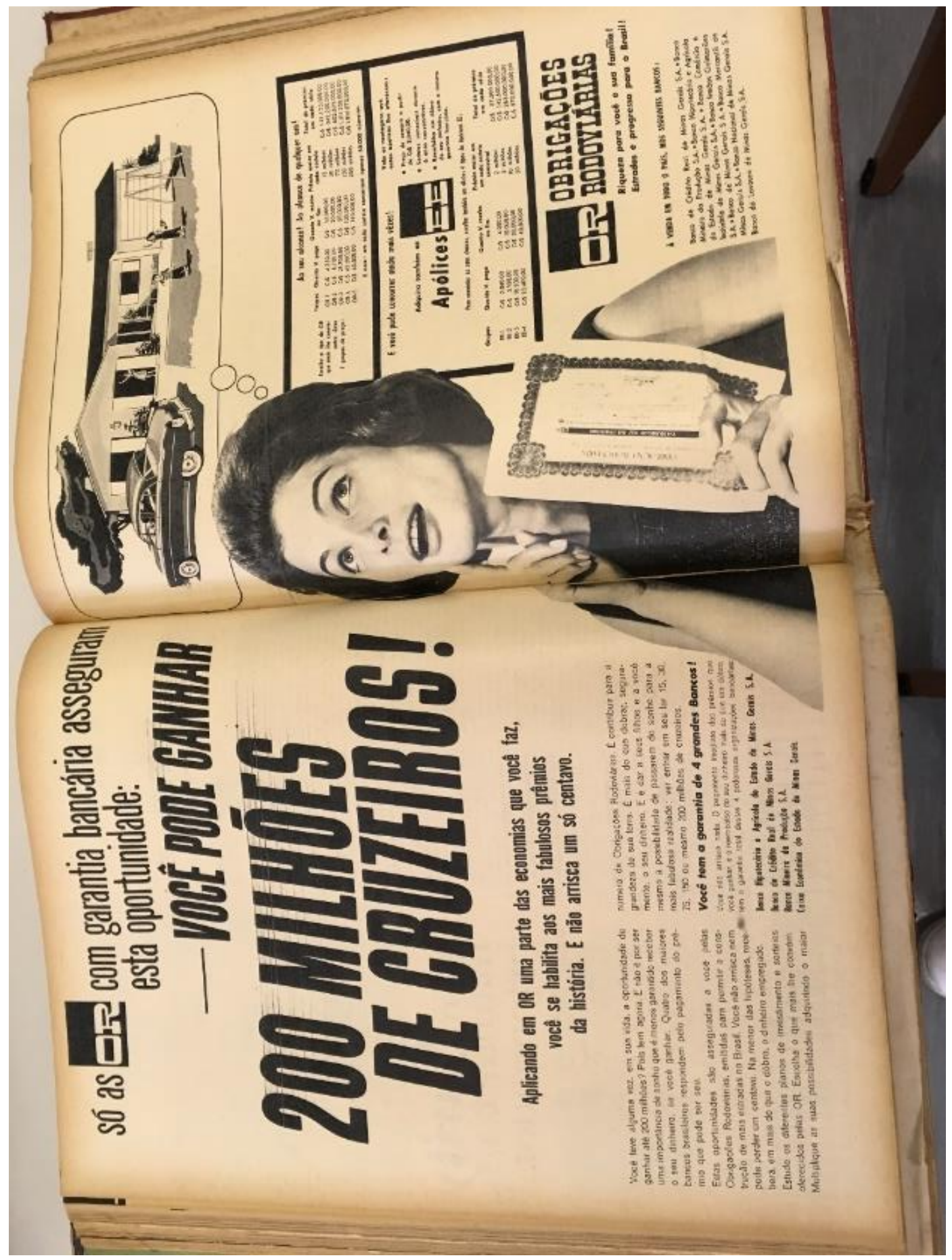


P2 Banco da Lavoura - Veja e Leia,17 set. 1969, n. 54, p. 72

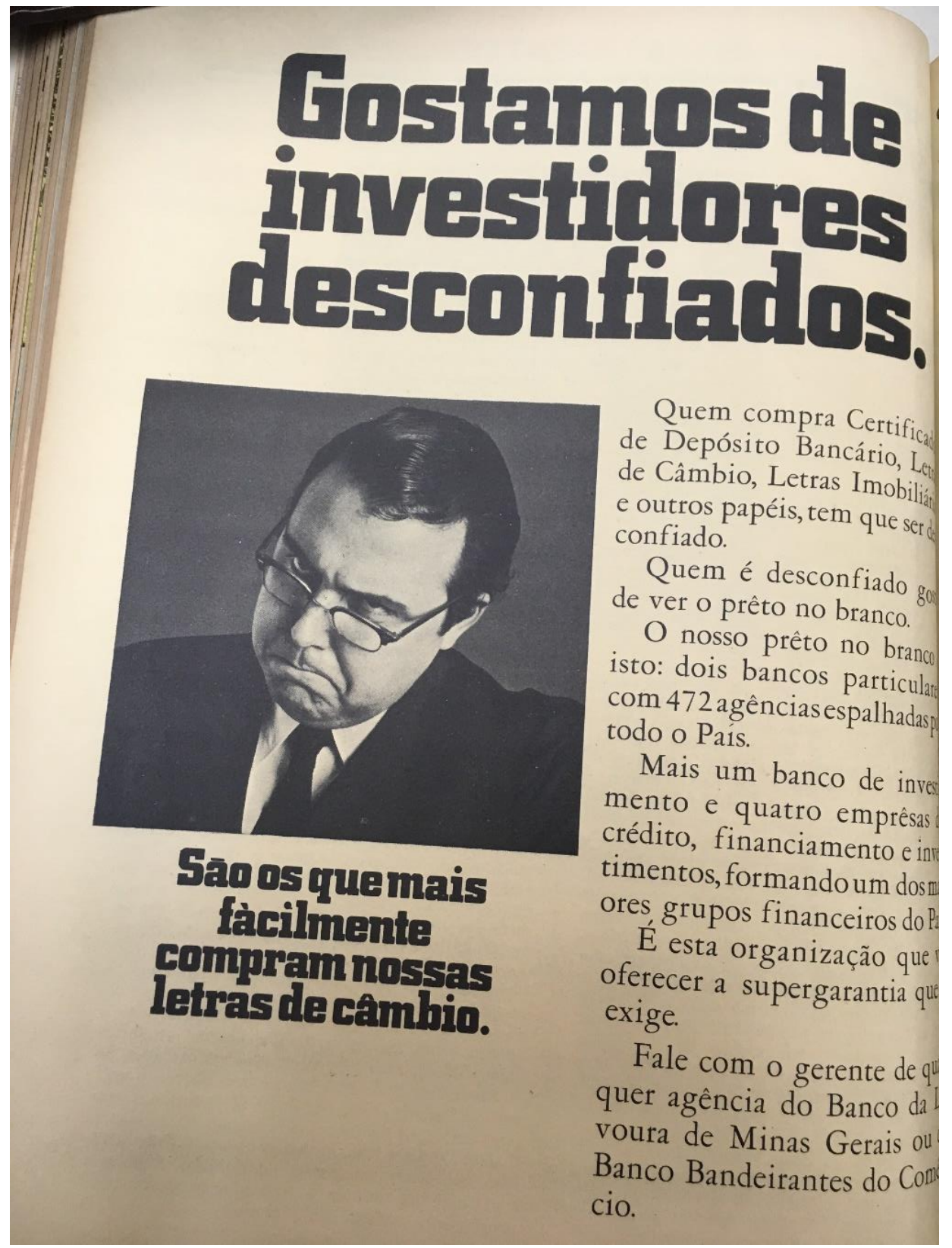


P3 Banco da Lavoura - Exame, set. 1969

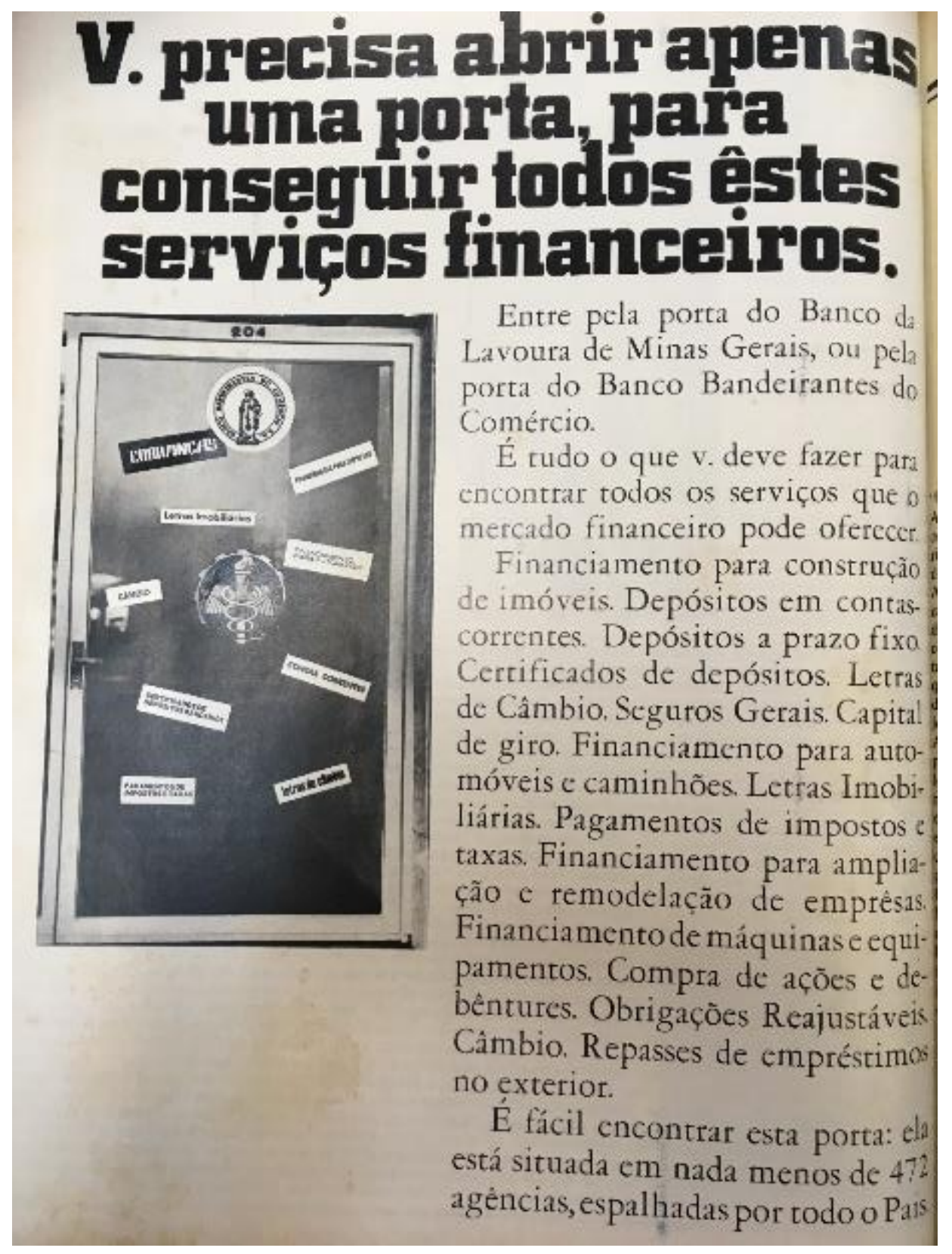


P4 Banco Real - Claudia, out. 1979, n. 217, p. 85

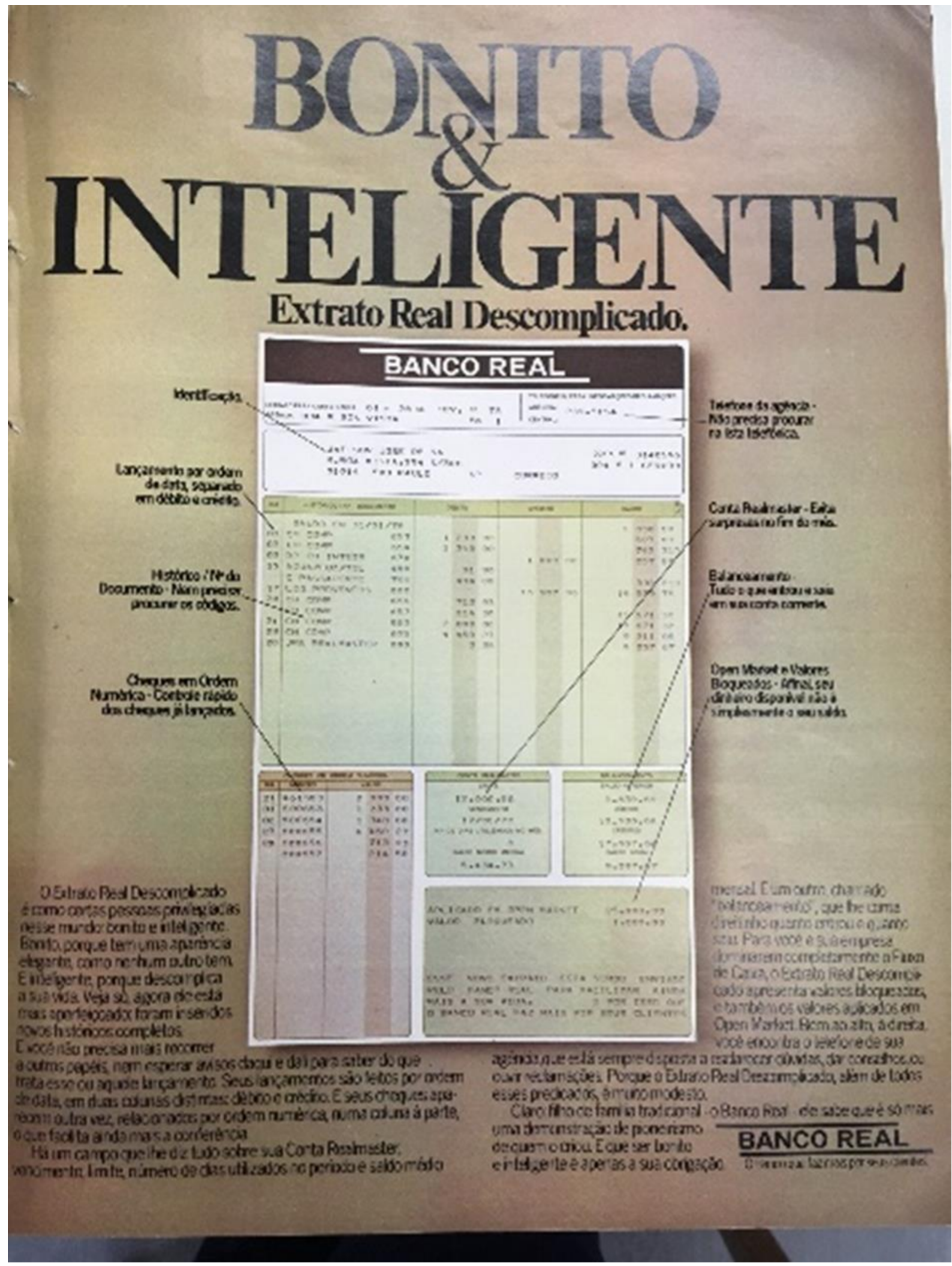


P5 Banco da Lavoura - Veja, jan. 1971

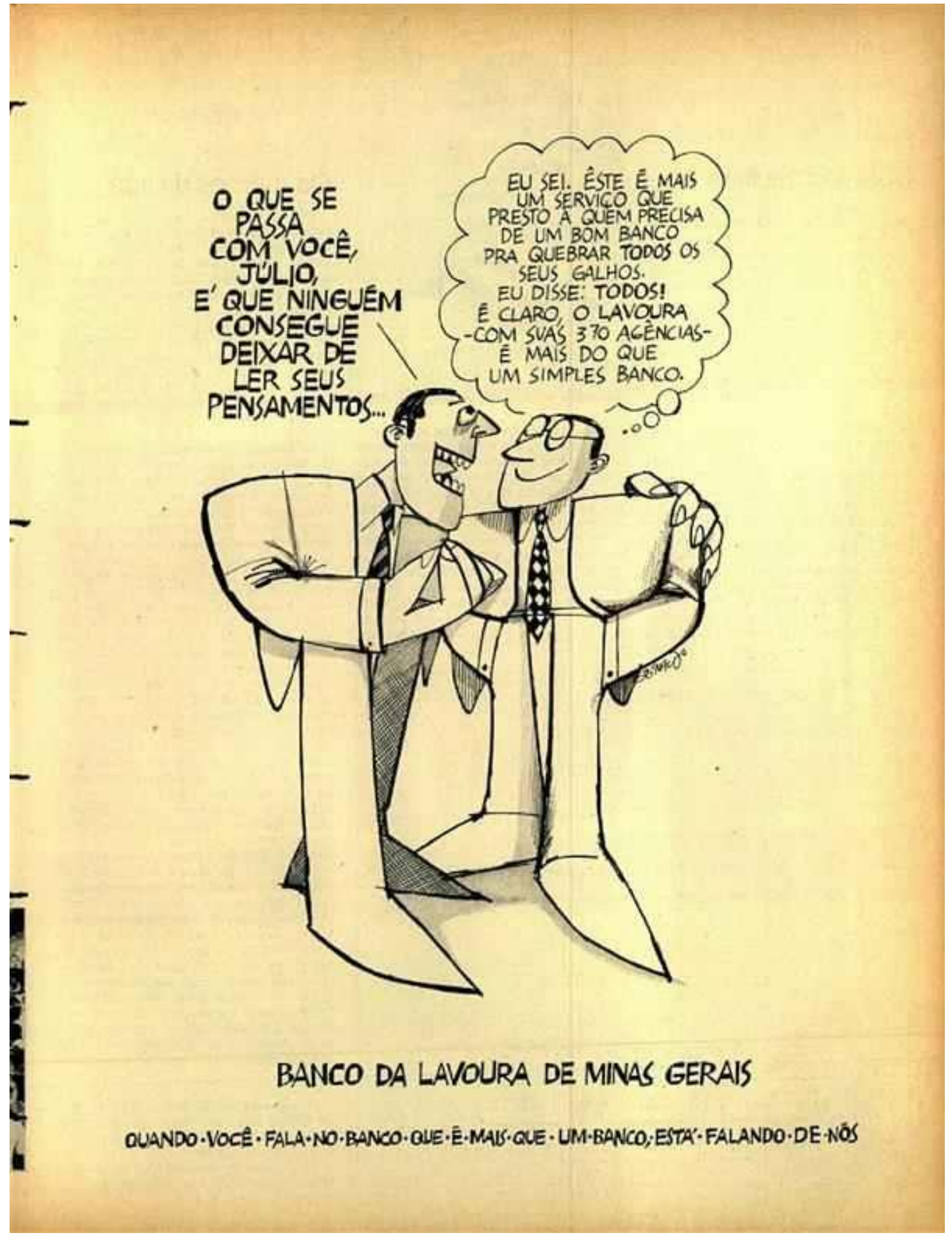


P6 Banco Real - Exame, 26 out. 1977, n. 138, p. 54

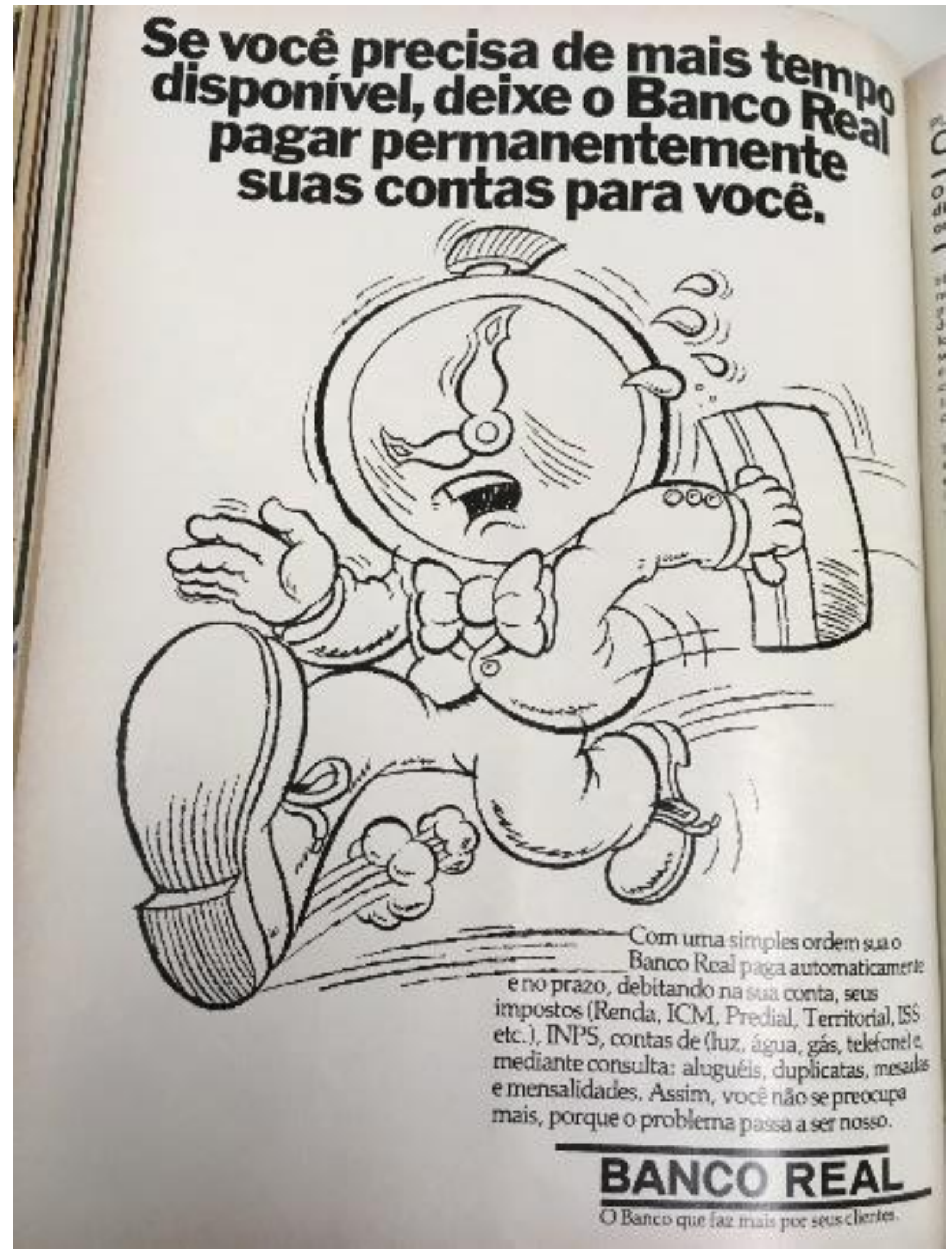


P7 Banco Real - Claudia, ano XIX, n. 229, out. 1980, p. 325

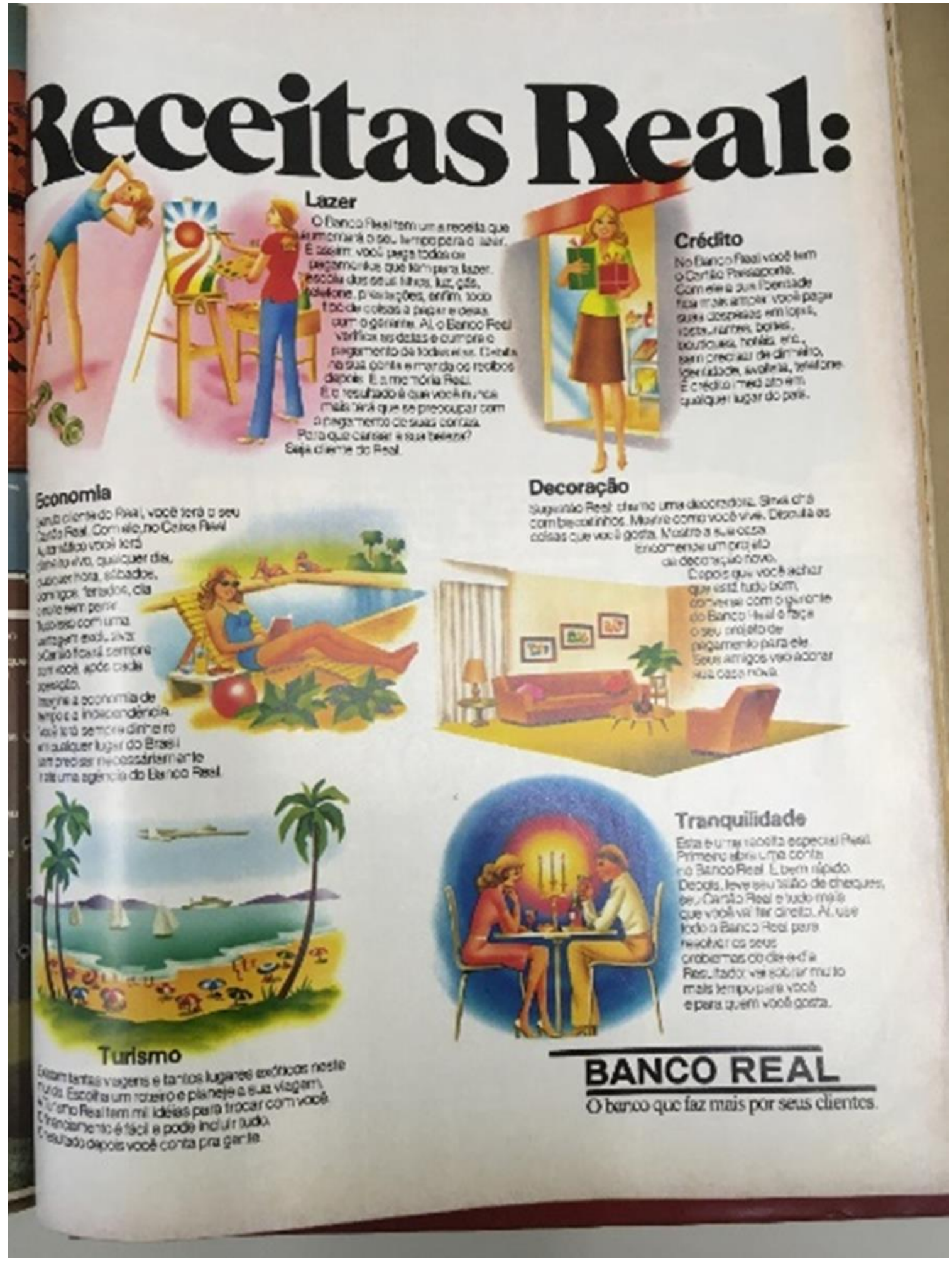


P8 Banco Real-Veja, n. 693, 16 dez. 1981

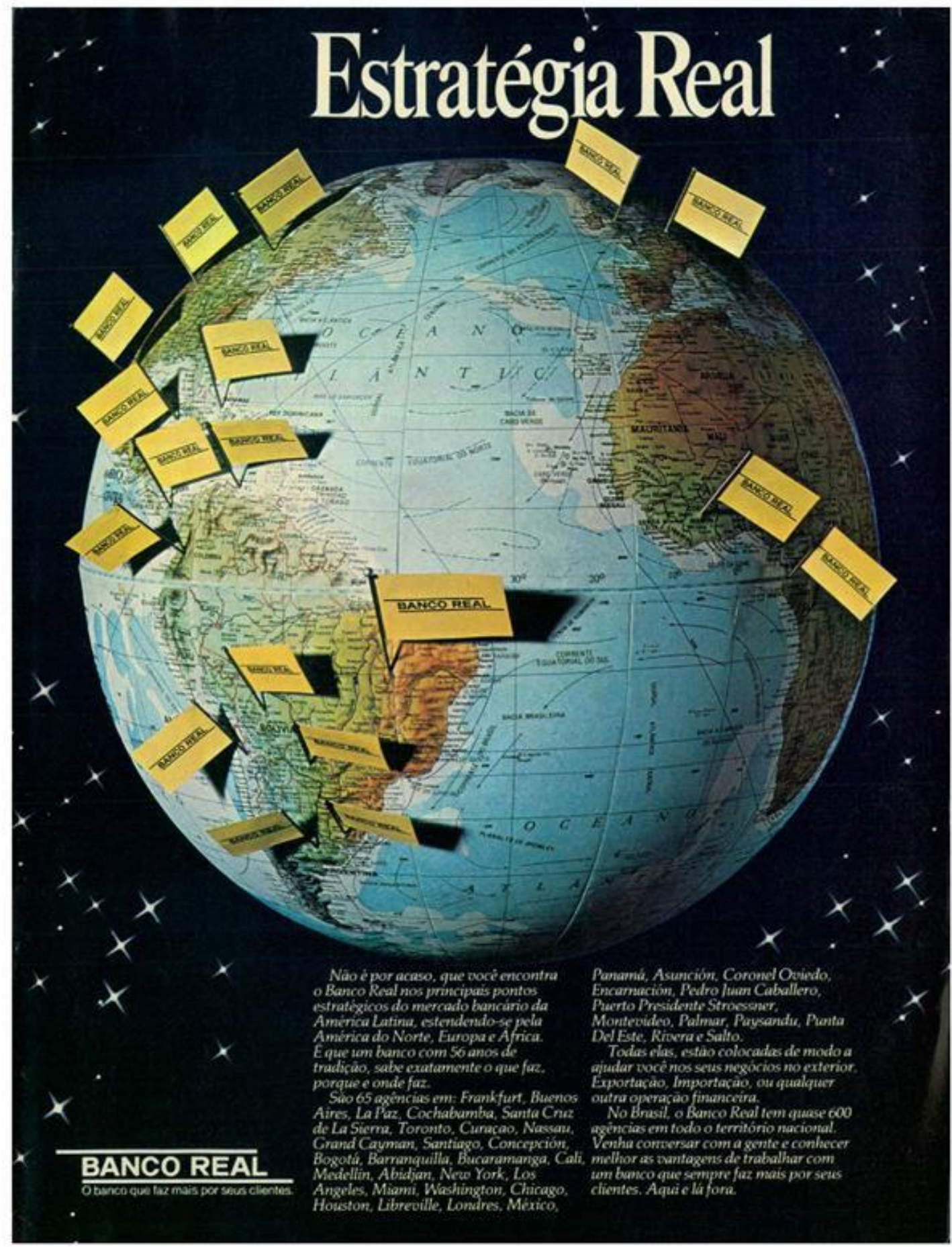


P9 Banco Real - Exame, n. 250, 5 maio 1982, p. 99

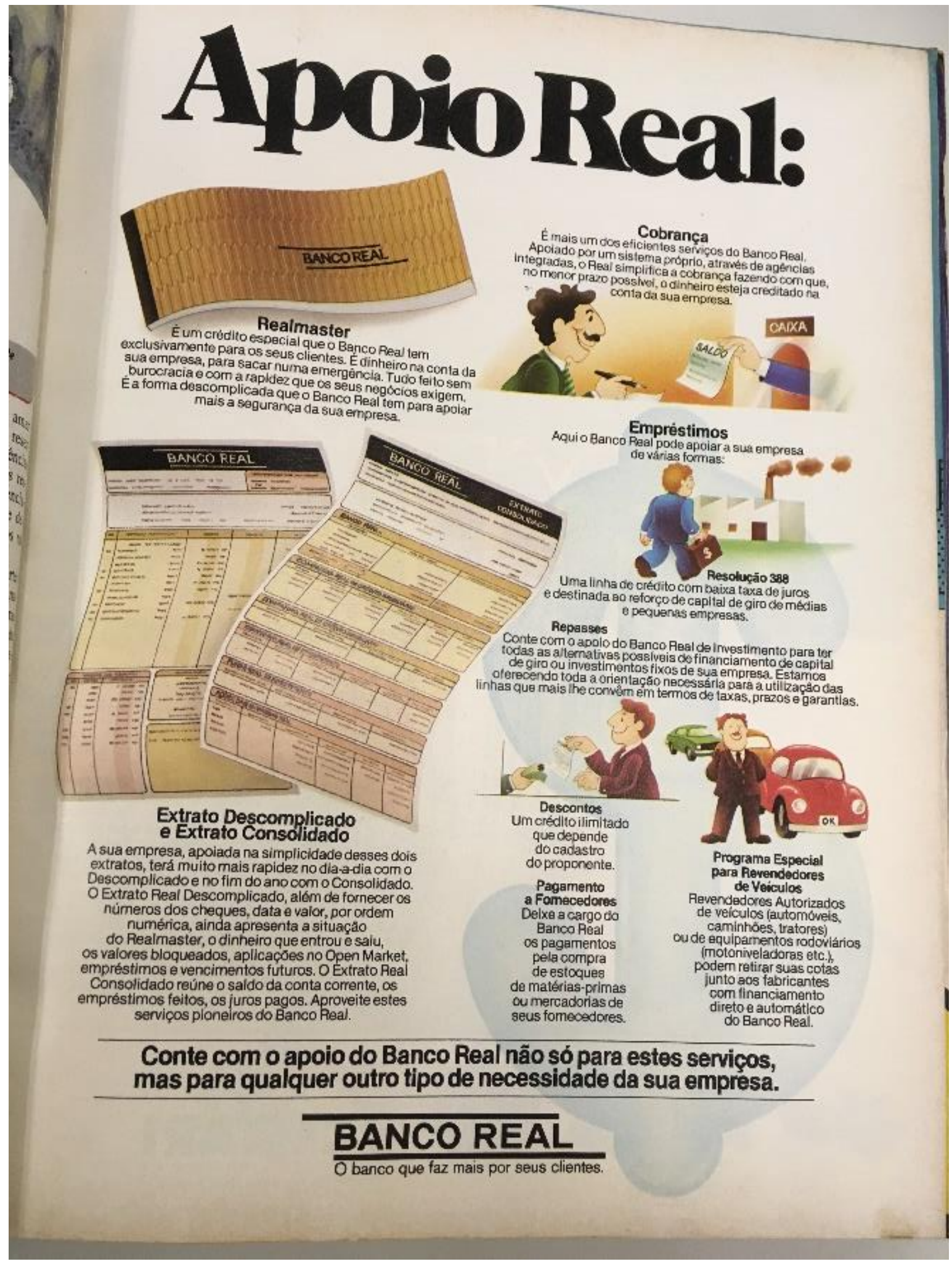


P10 Banco Real - Claudia, dez.1997

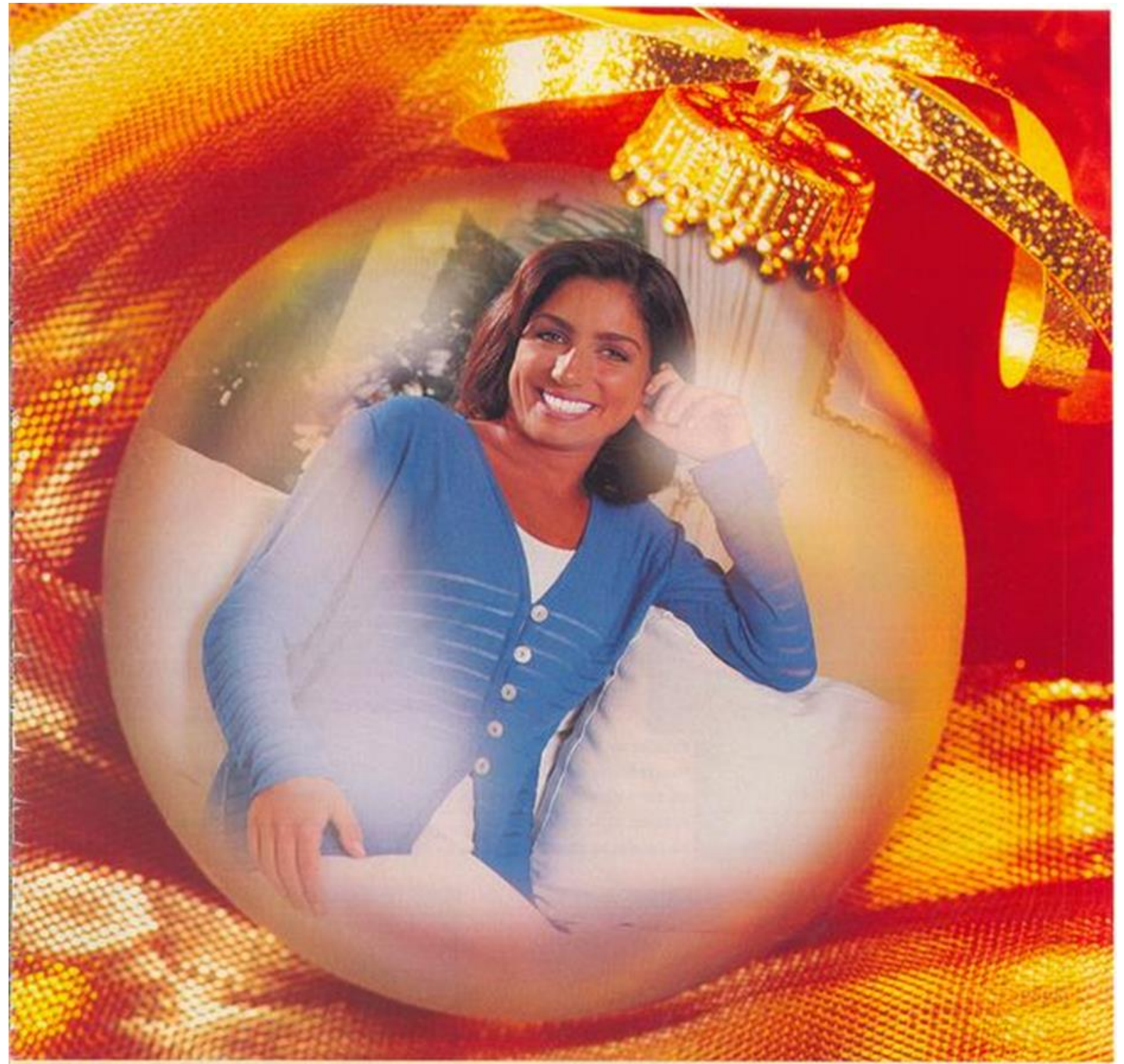

\section{Para ter um ano próspero, use a intuição e o bom senso nos negócios.}

Vem ano, vai ano, e a mulher que ouve a própria intuição continua valorizando o bom senso. E o bom senso recomenda fazer negócios com o Banco Real. Produtos e serviços de qualidade para você que, intuitivamente, sabe 0 que é bom para sua realizaçăo pessoal e para a prosperidade de sua familia. Comece 98 com o Banco Real. Uma virada cheia de vantagens para o seu dia-a-dia. E bom senso para o ano inteiro.

Banco Real 
P11 Banco Real - Veja, jun. 1992, ano 25, n. 26, ed. 1240, p. 56-57

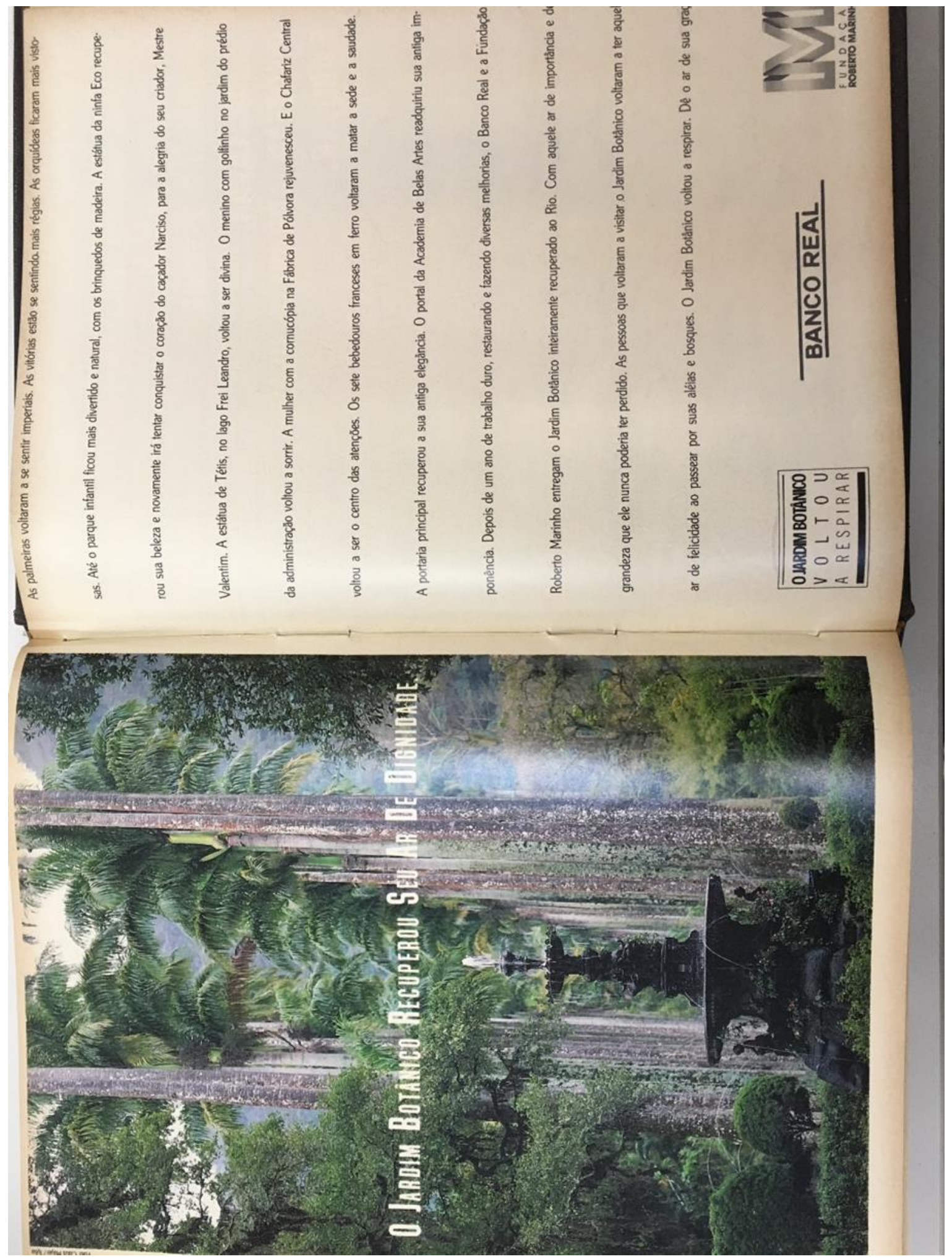


P12 Banco Real - Exame, ano XXVIII, n. 21, ed. 594, 11 out. 1995, p. 90-91

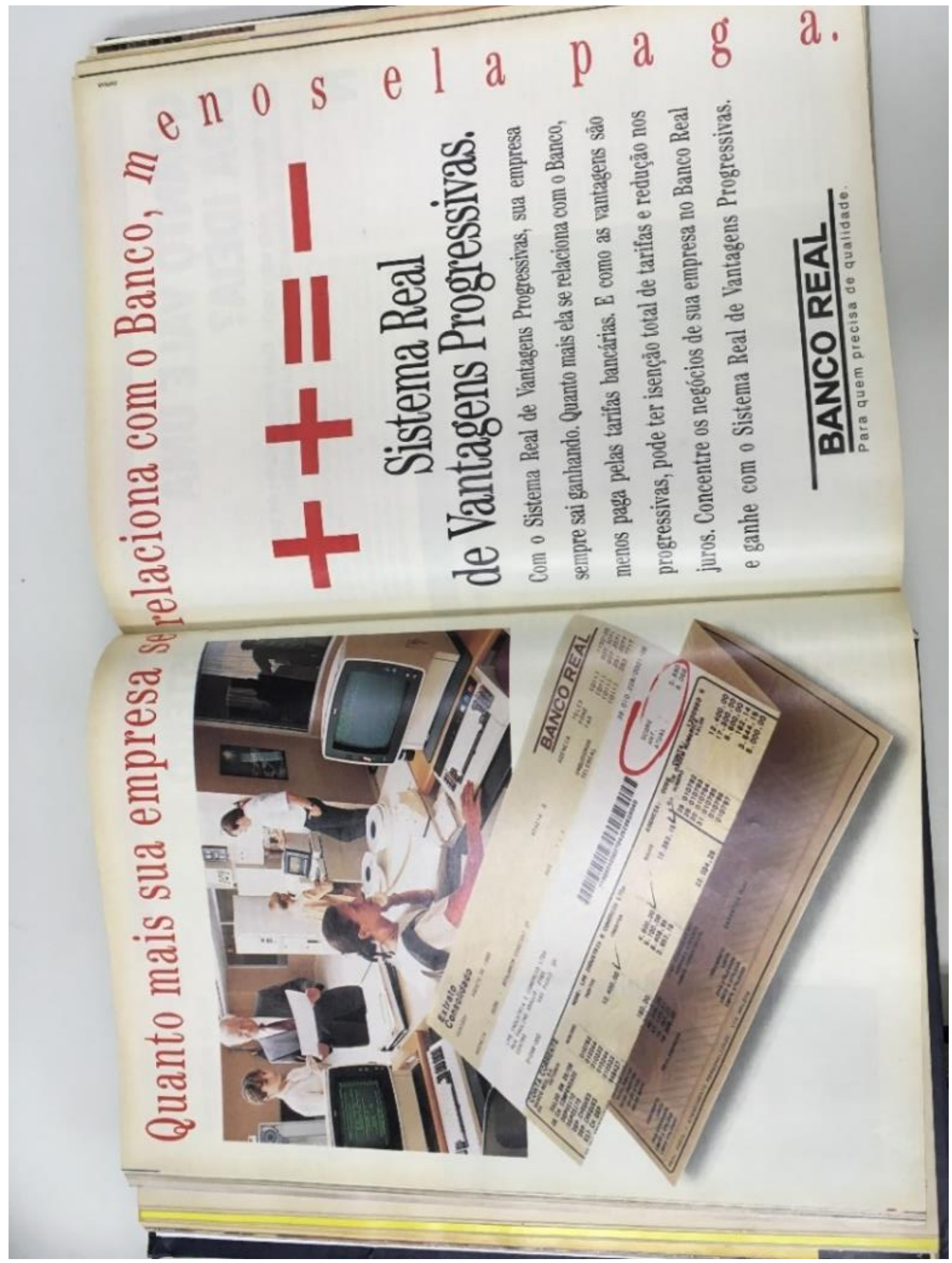


P13 Banco Real - Claudia, ago. 2003

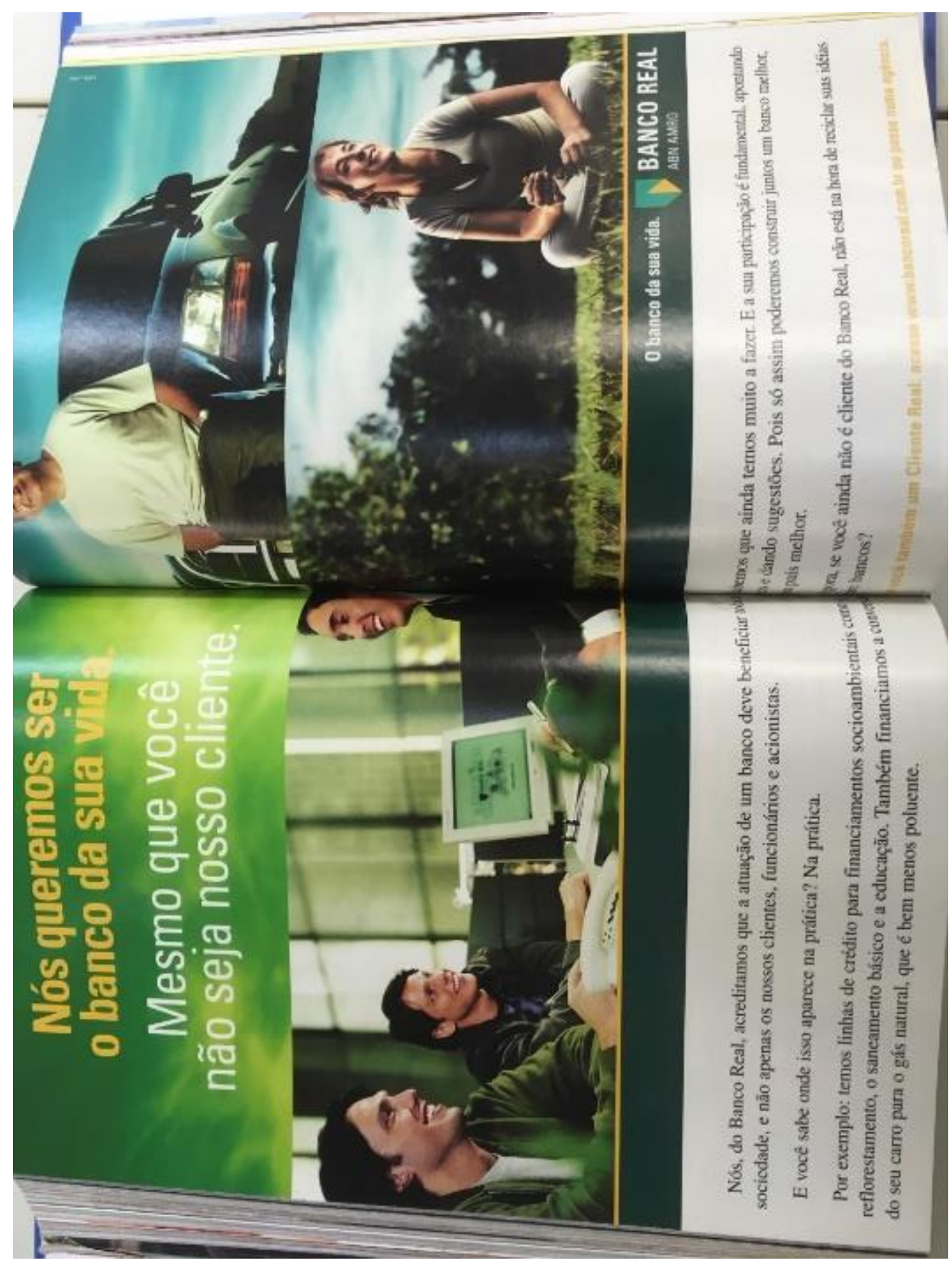


P14 Banco Real - Veja, ago. 2008

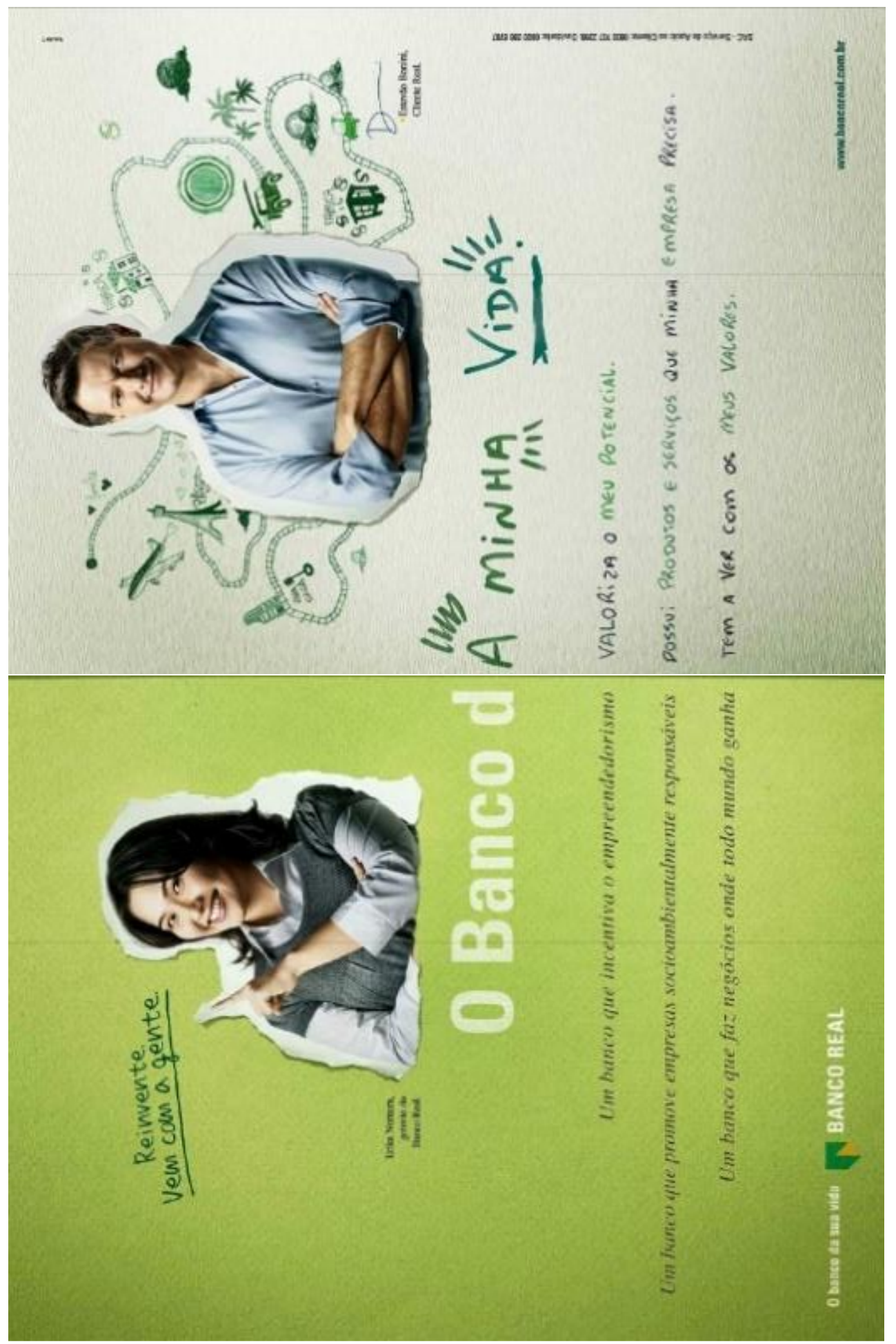


P15 Banco Real - Exame, fev. 2003

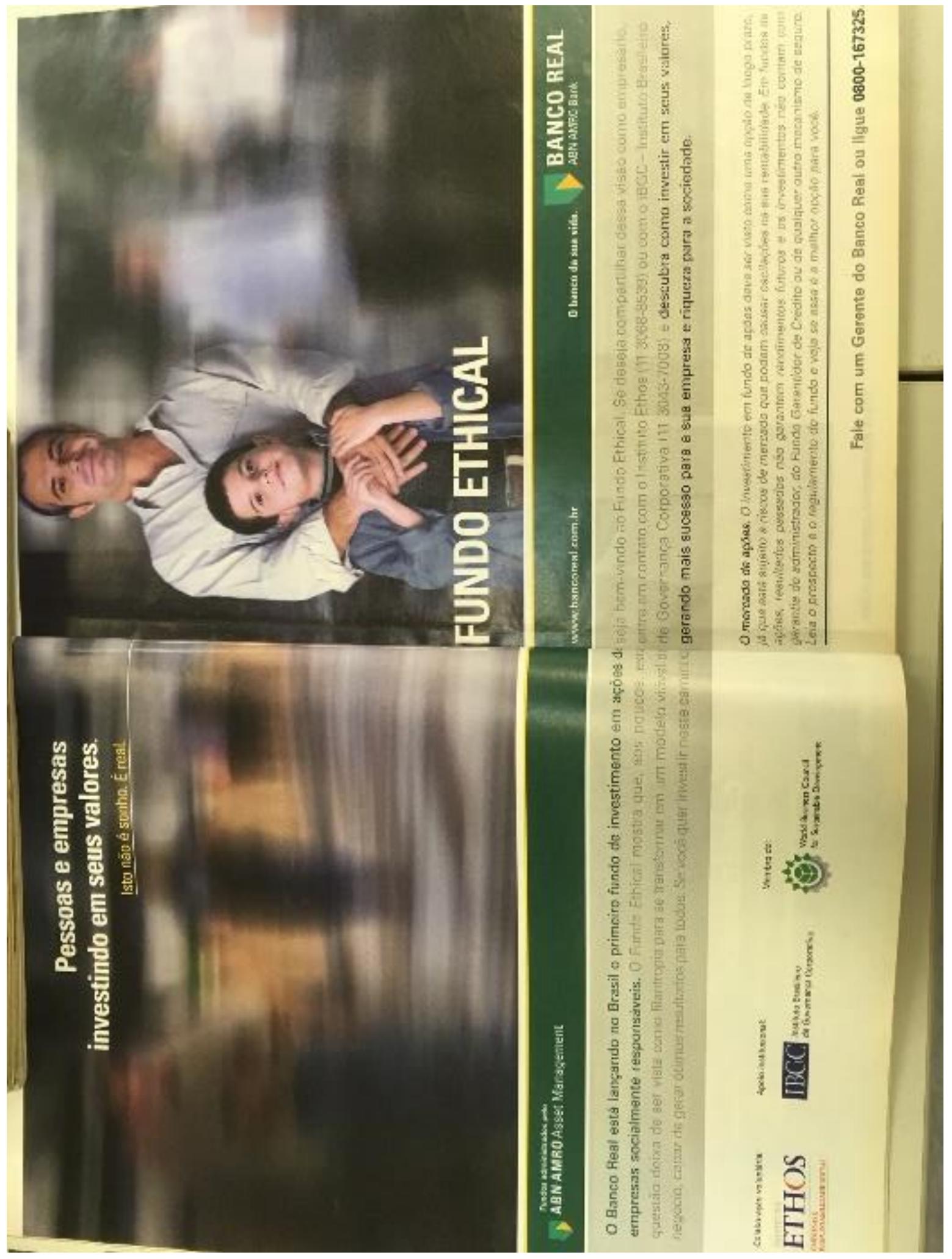


P16 Banco Santander - Claudia, mar. 2018

\section{DESAFTO BOA FORMA SANTANDER}

INSPIRAÇÕES QUE VÃO TRANSFORMAR SEUS HÁBITOS

Desafiamos cinco leitoras de BOA FORMA, que são clientes SANTANDER, a treinar com a gente durante seis meses.

Elas vão suar o top em estações de ginástica

Santander, training trucks e academias ao ar livre.

\section{ACOMPANHE A COBERTURA COMPLETA NAS PRÓXIMAS EDIÇÕES DA REVISTA, NO SITE E NAS REDES SOCIAIS DE BOA FORMA}

\section{boaforma.com.br}

\#DesafioBoaFormaSantander

APRESENTADO POR

REALIZAÇÃo

Santander 89 GRUPO 1 Abril

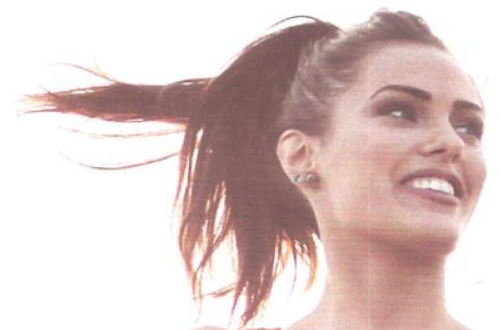


P17 Banco Santander - Veja, maio 2010

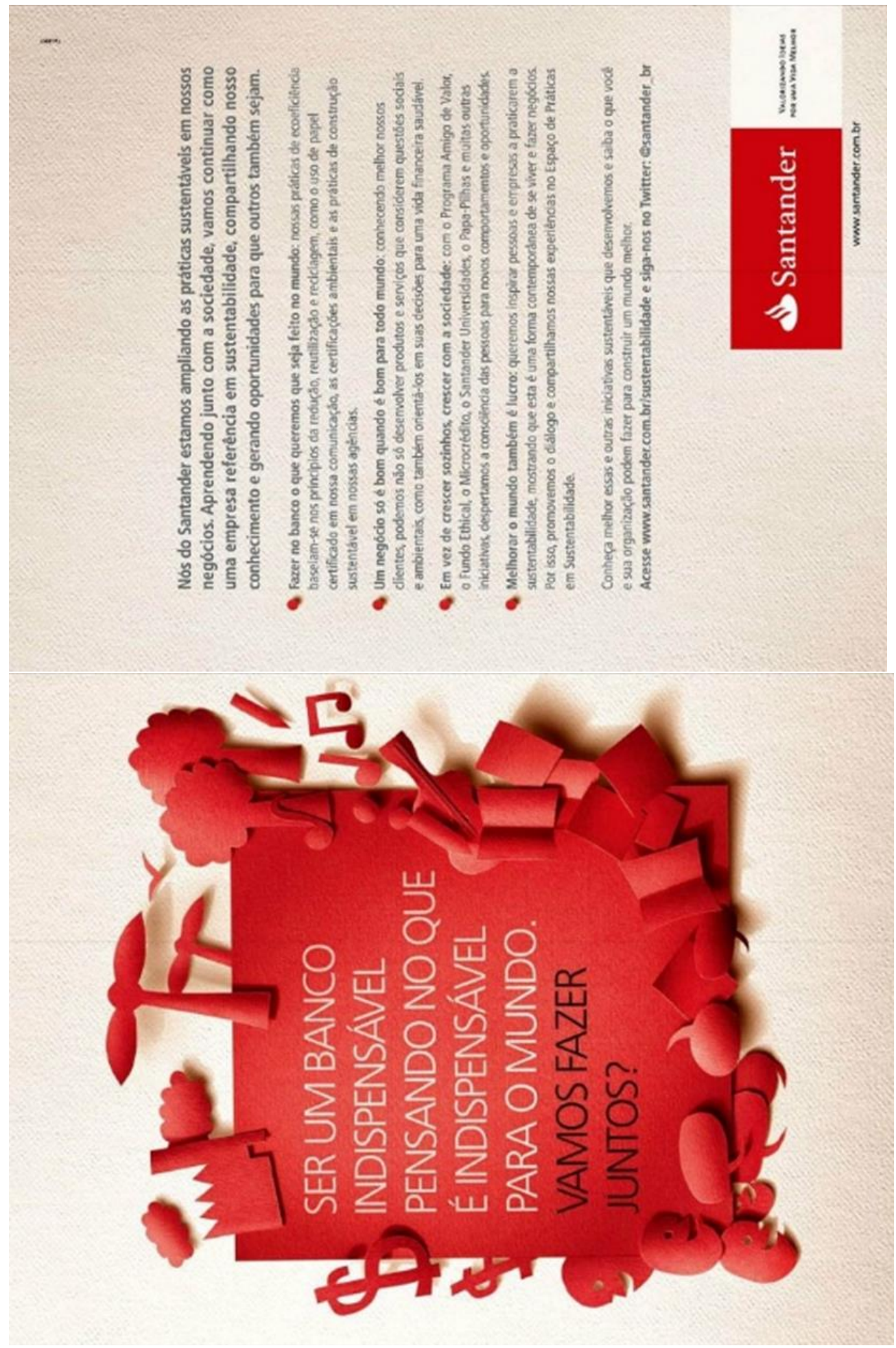


P18 Banco Santander - Exame, jul. 2018

A GENTE FALA

O QUE OS OUTROS

BANCOS NÃO FALAM:

CHEQUE ESPECIAL

FOI FEITO PARA

EMERGÊNCIAS.

- Santander Master. O único que oferece 10 dias sem juros para todos os clientes, porque entende que emergências acontecem.

Busque por Santander Master

O QUE

A GENTE

PODE

FAZER

POR VOCÊ

HOJE? 


\section{ANEXO B - Exemplificações}

Figura 1 - Veja, jan. 1989

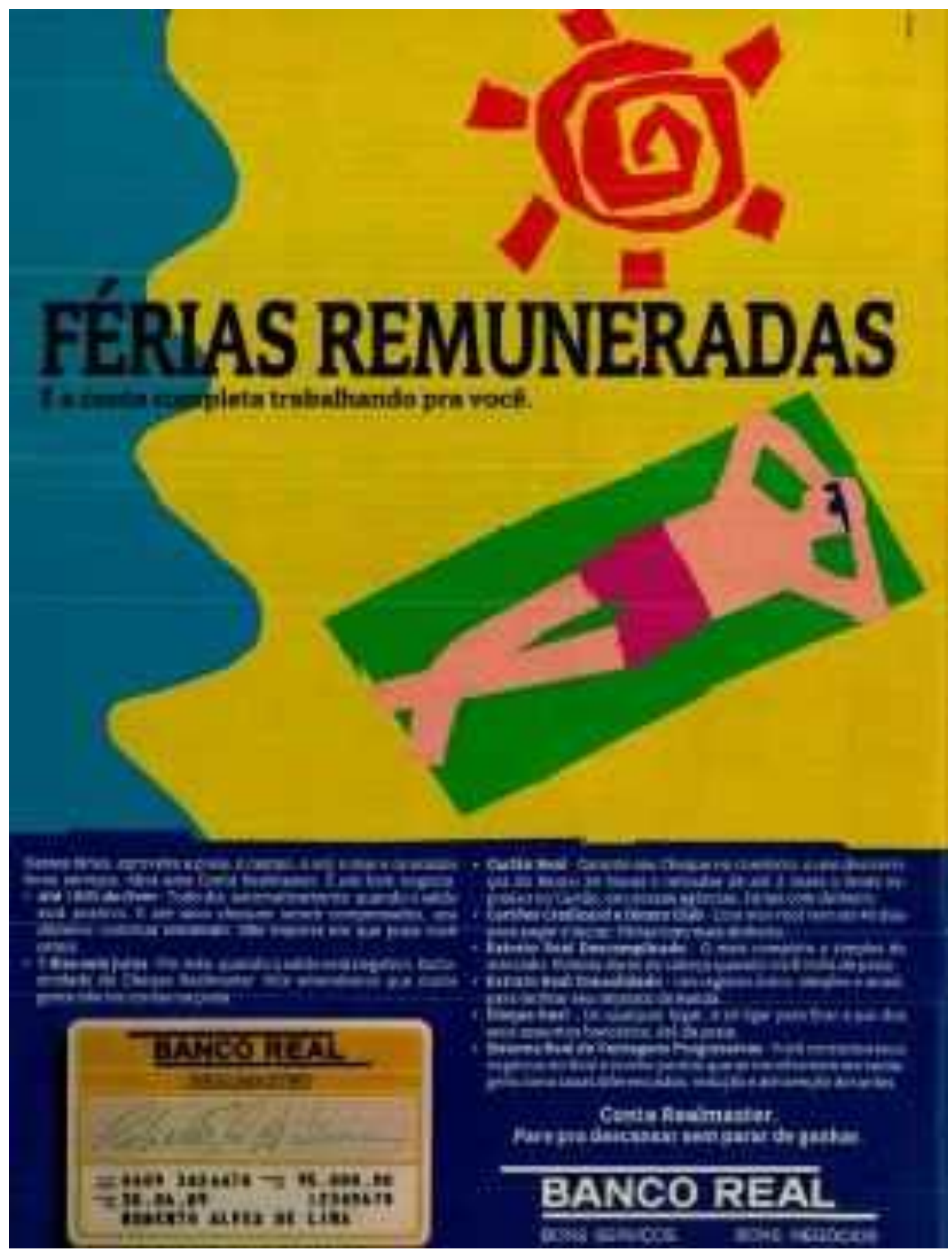


Figura 2 - www.propagandaemrevista.com.br

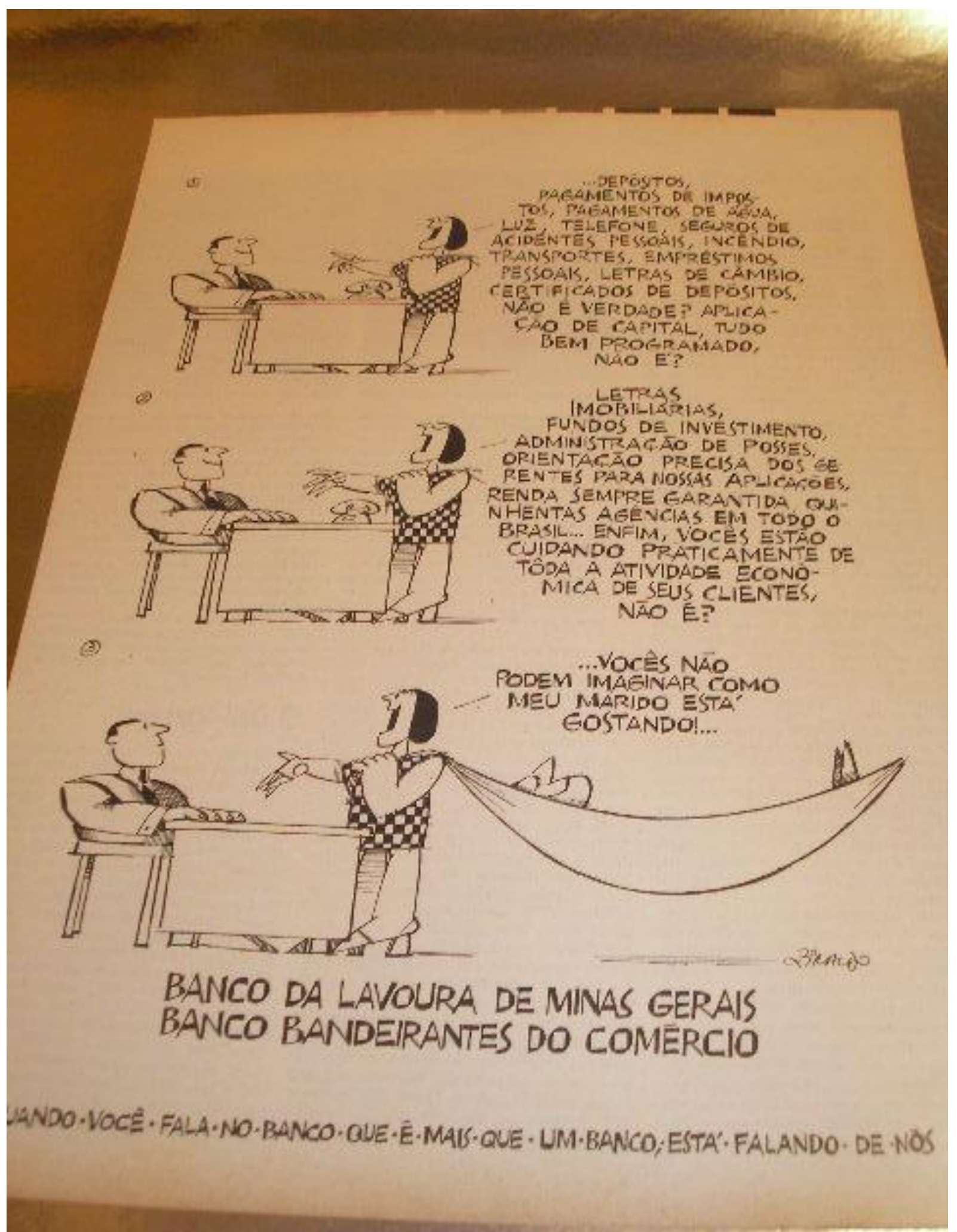


Figura 3, 11 e 15 - Veja, dez.2003

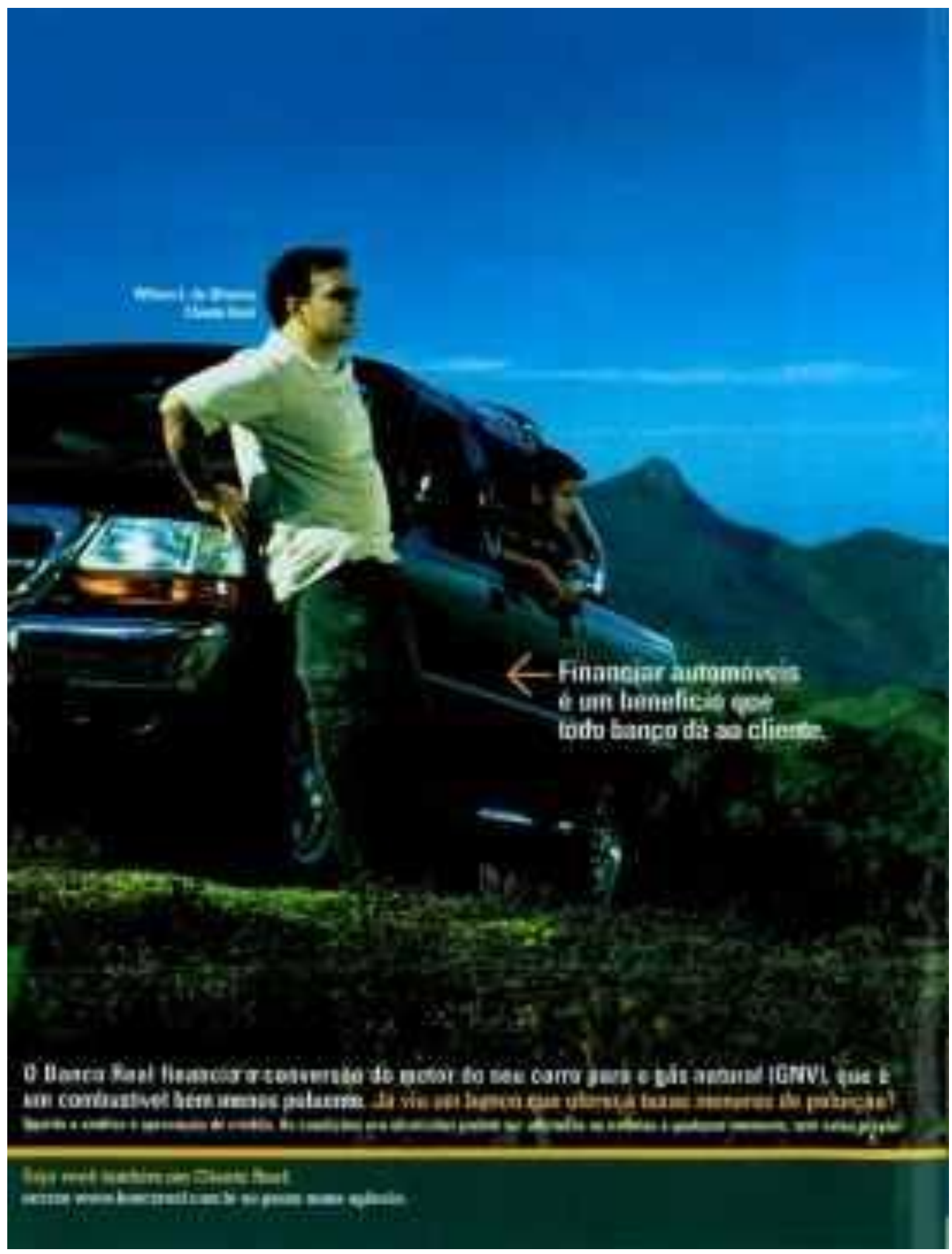


Figura 4 - Veja, jan.2001

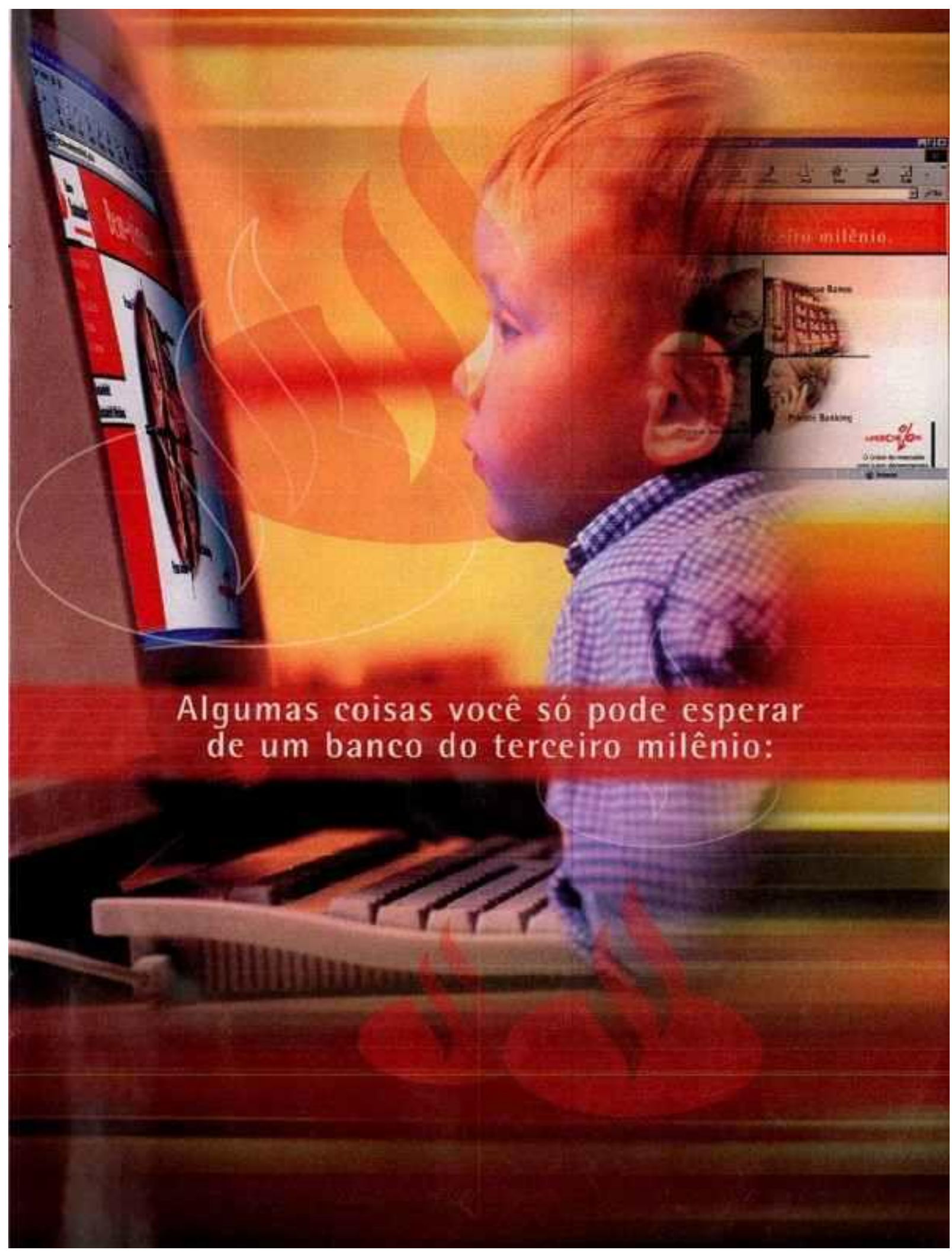


Figura 5 - Exame, dez. 1970

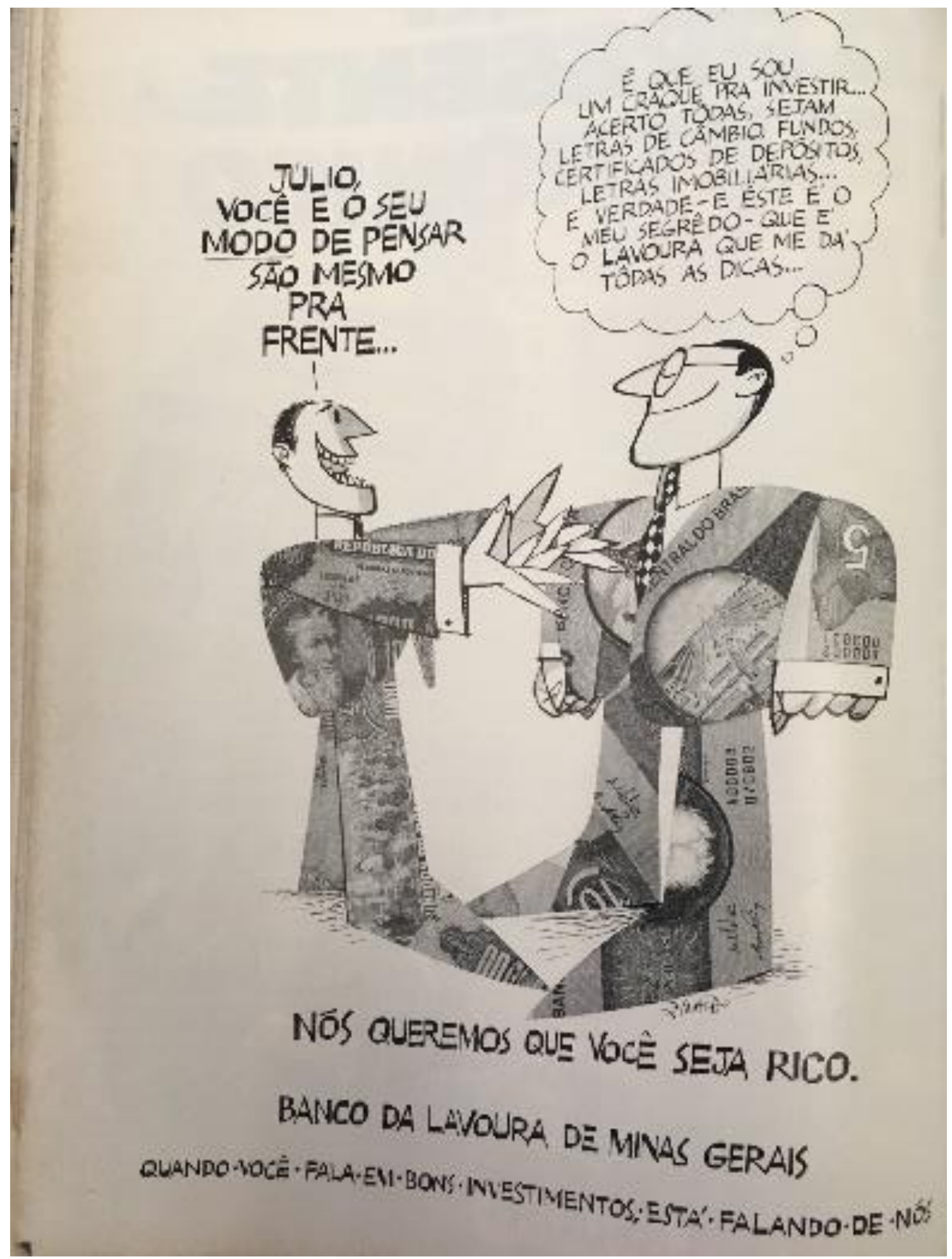


Figura 6 - Veja, jun. 2006
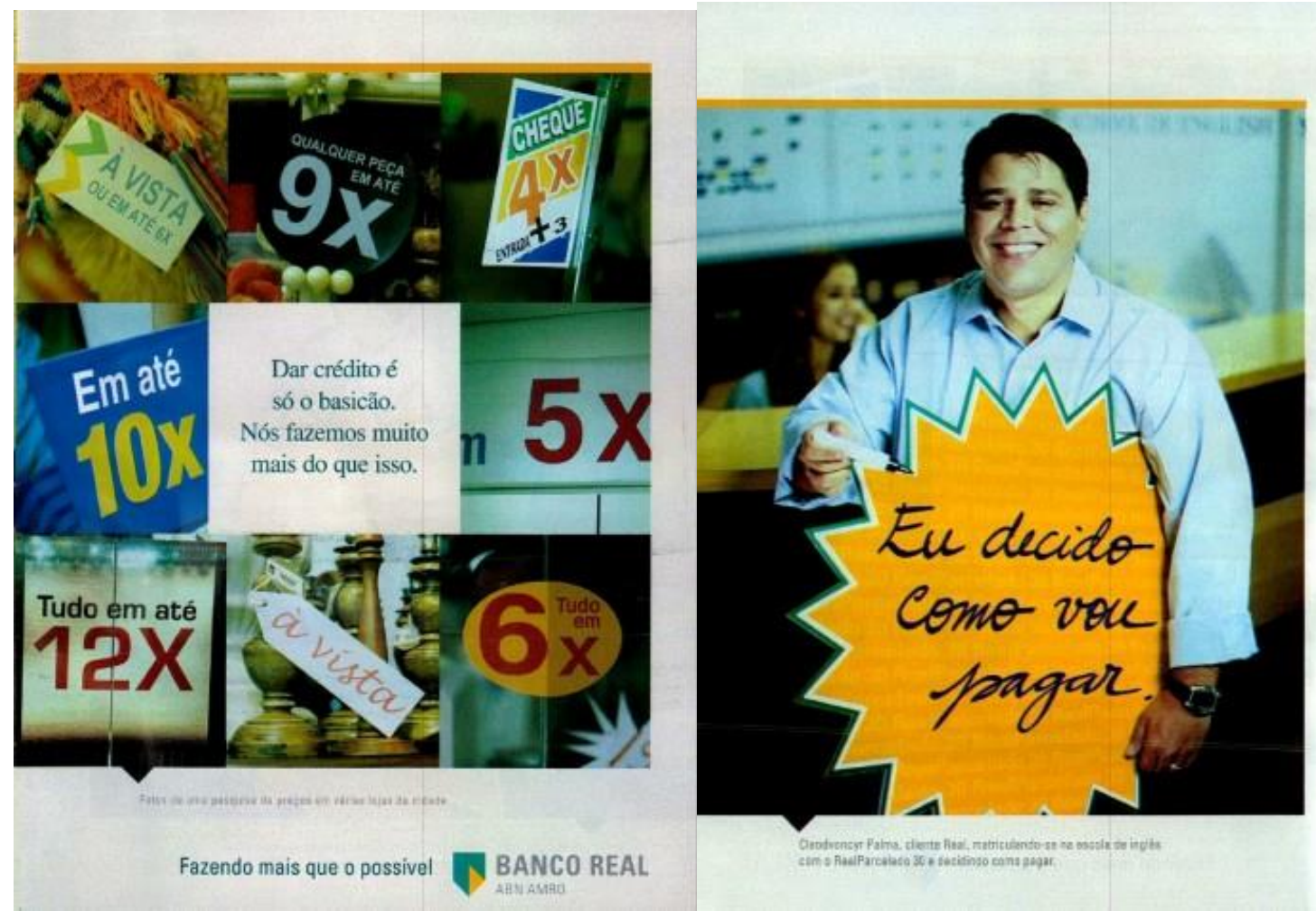
Figura 7 - Veja, jun. 2001

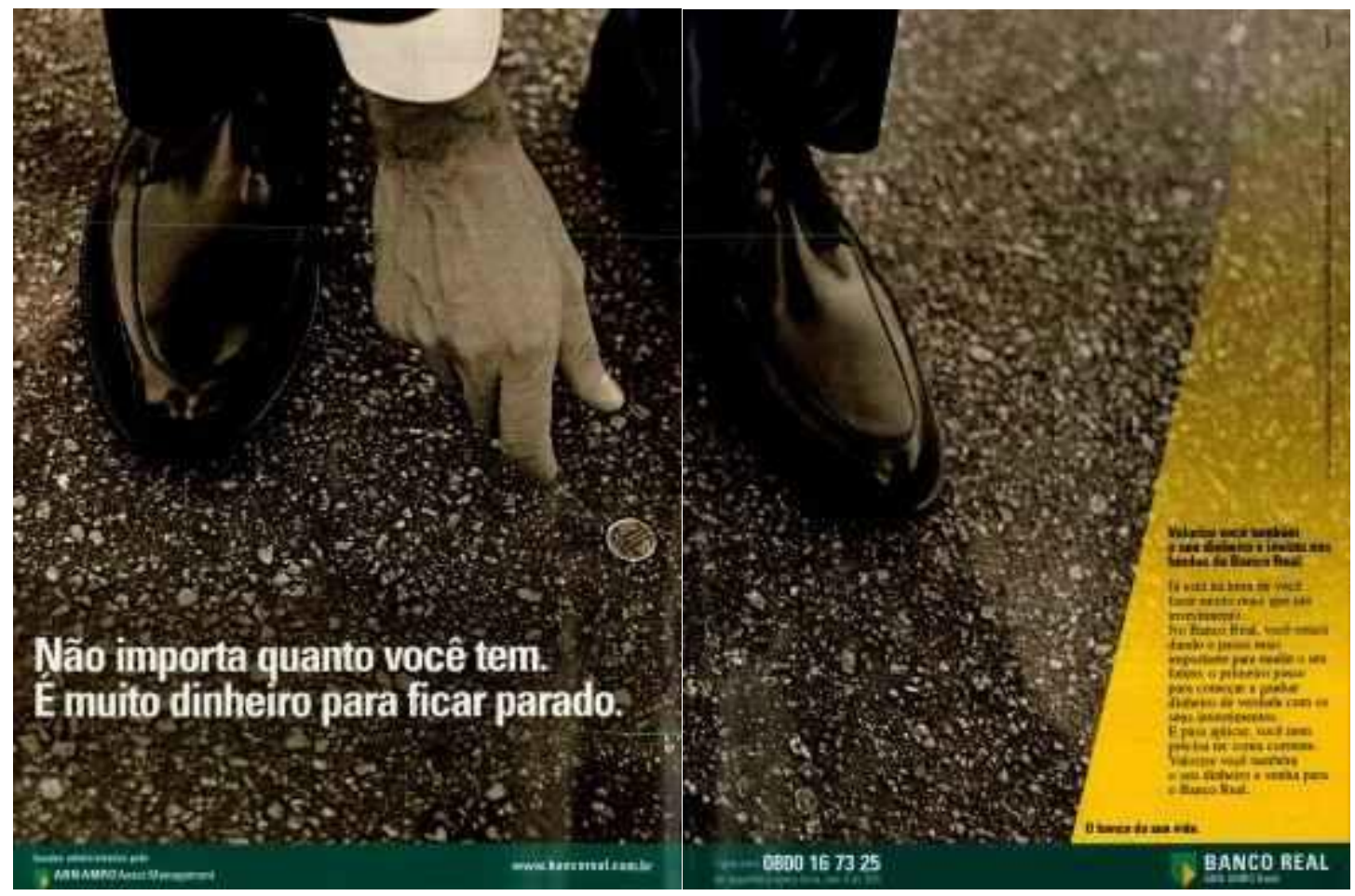


Figura 8 - Claudia, jul. 1997

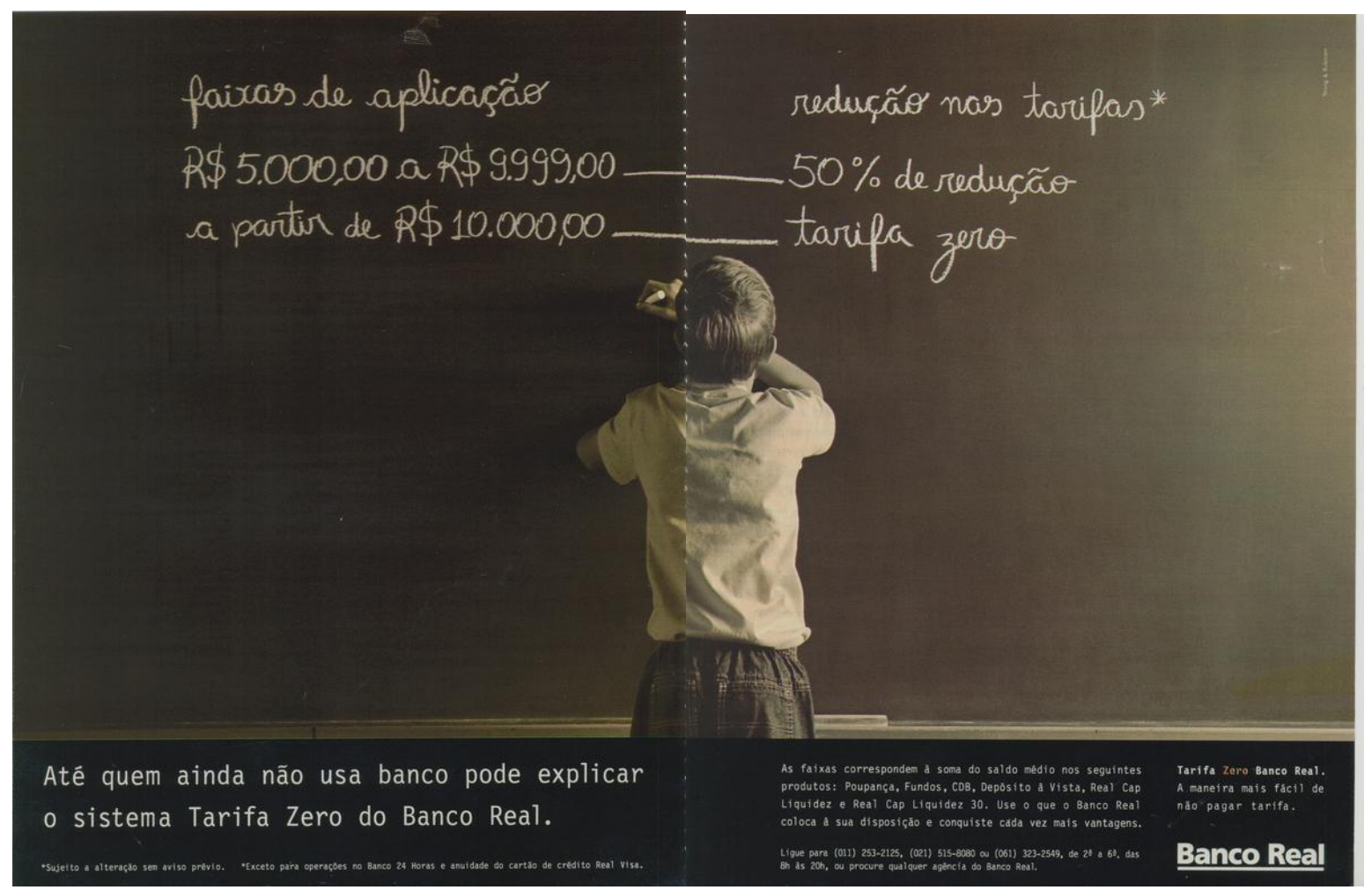


Figura 9, 13 e 14 - Veja, out. 1996

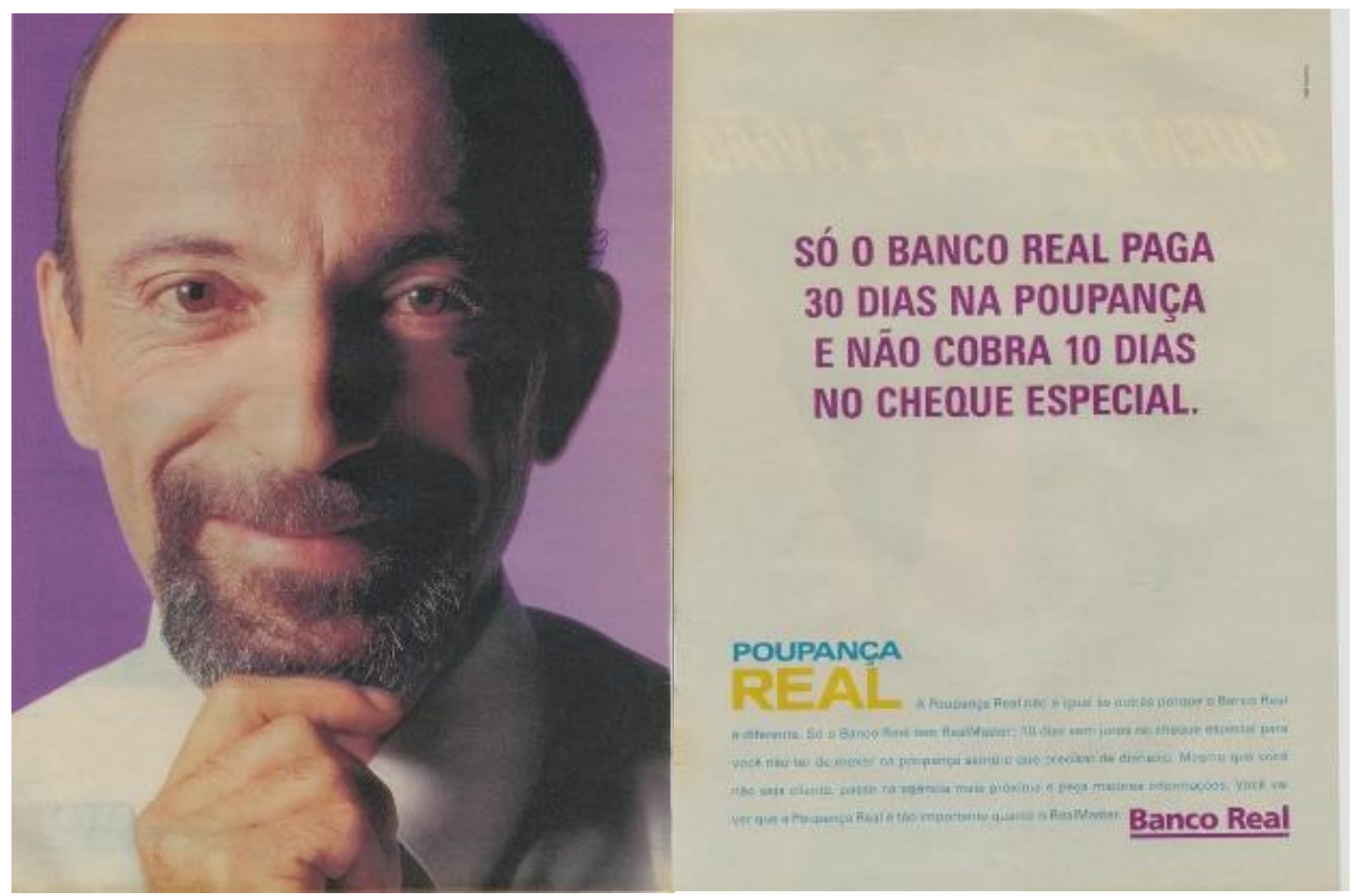


Figura 10 - Veja, mar. 2000

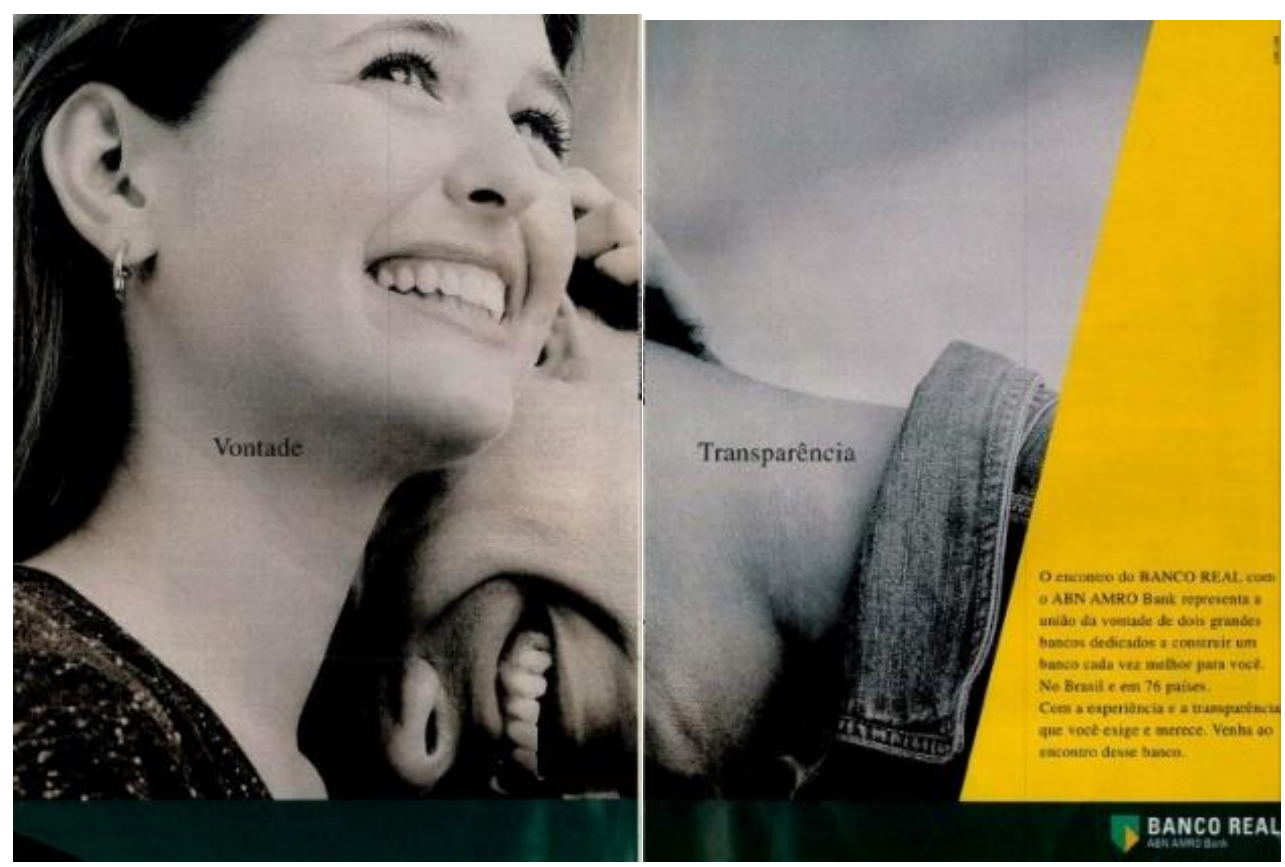


Figura 12 - Veja, mar. 2002

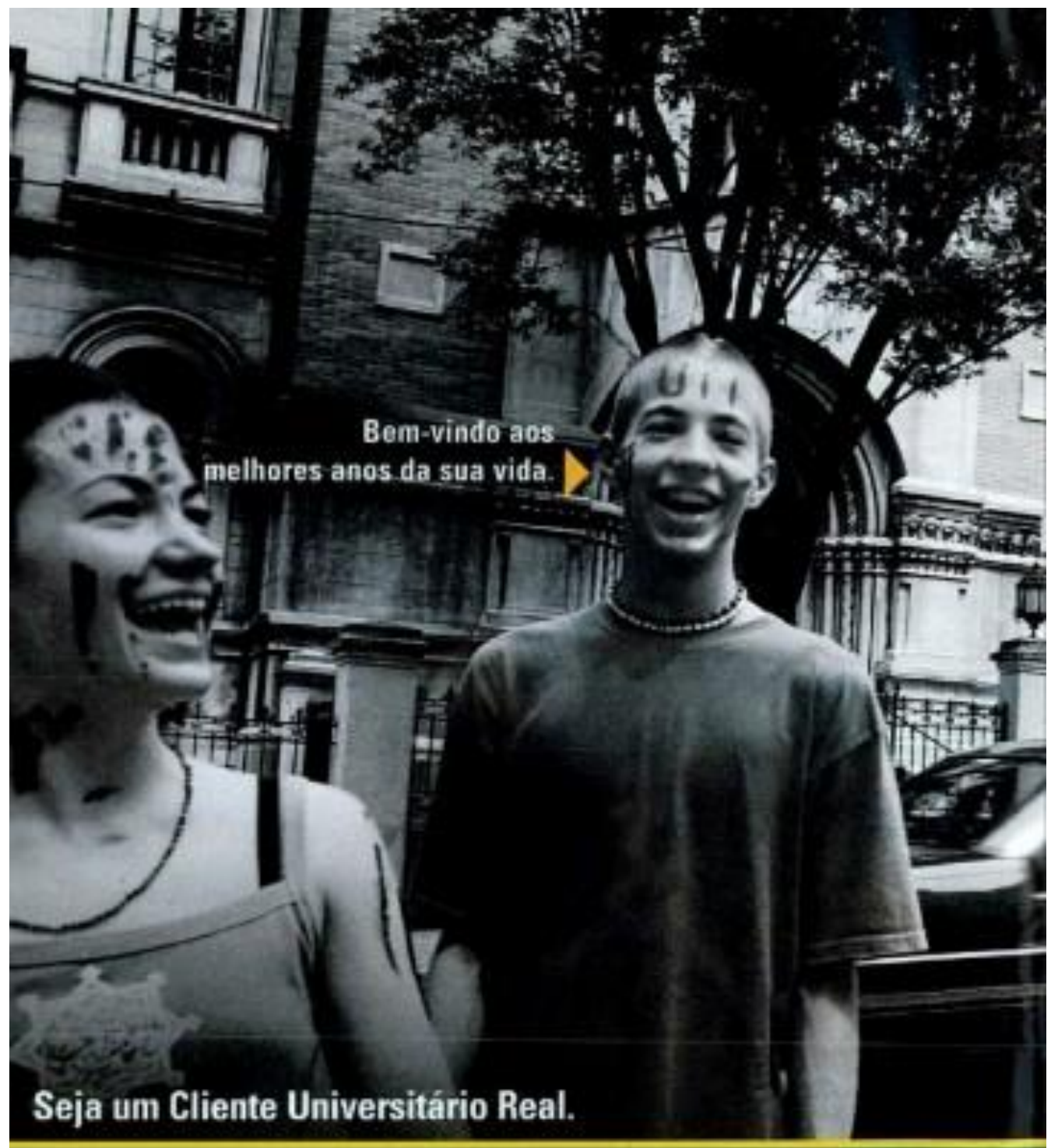

Abra vocè tambèm sua conta: ligue 08007702001. acesse www hancorealcombr ou passe numa apcincia.

Pesca no vesihular? Parahéas, Agres pave no Banos Rral. Vict apreveia e Programa Daiversicirio Real e itre sui conta correate sem precisor compowar reada.
Voct pode pedir seu limete Realmasser", que di 10 das ien jusos, por més, no heyae espocial. Pode salicitar scu carbo Real Visat. Fode asar o Real Inicreat 
Figura 16 - www.propagandaemrevista.com.br

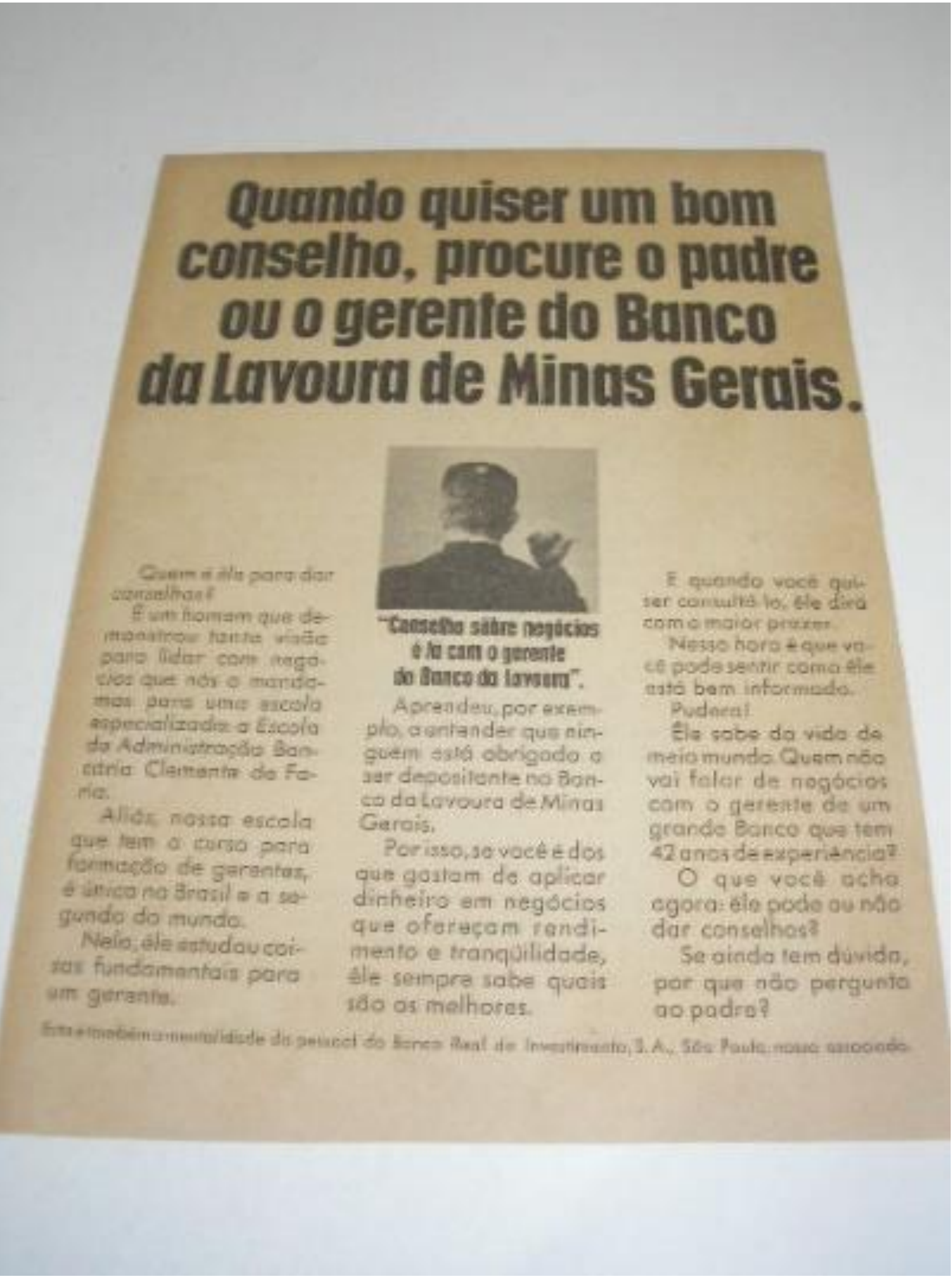


Figura 17 - Exame, ago. 1985

\section{tem soluçōes compó um Banco completo}

Coavenins, Tributas, Begures. Imwentimentes.

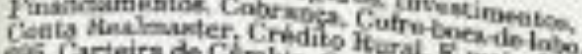

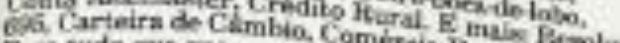

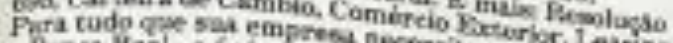

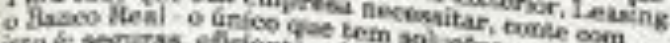

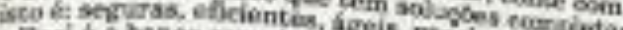

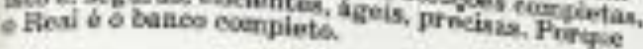

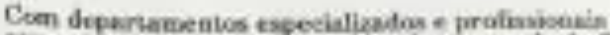

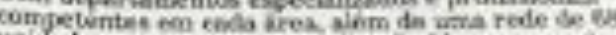

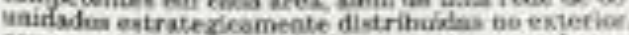

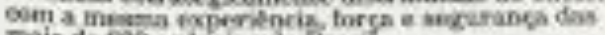

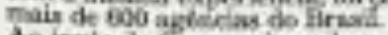

Ao inves die scar quetenando a catwech a procurs da.

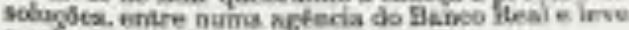

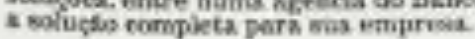

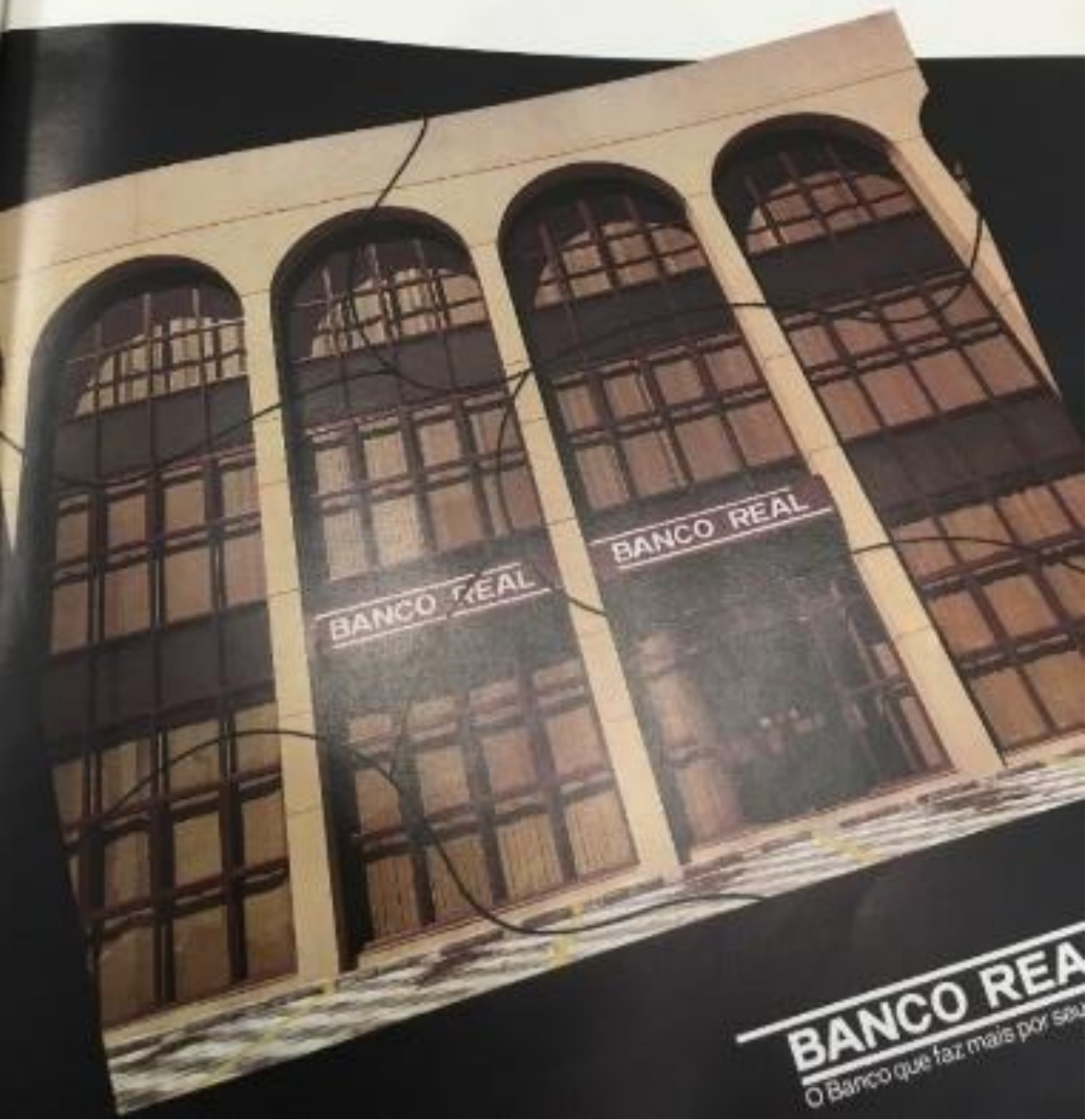


Figura 18 - Veja, jun. 2002

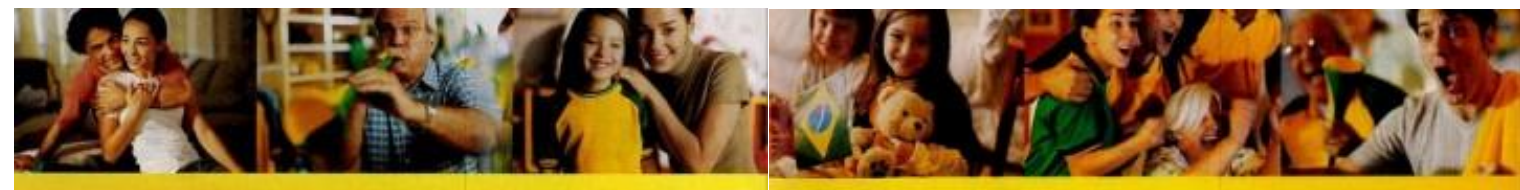

Num país de índios, I BANCO REAY europeus, africanos e asiáticos, pode faltar tudo, menos raça.
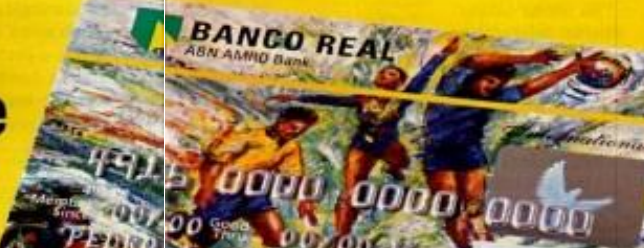

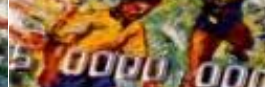

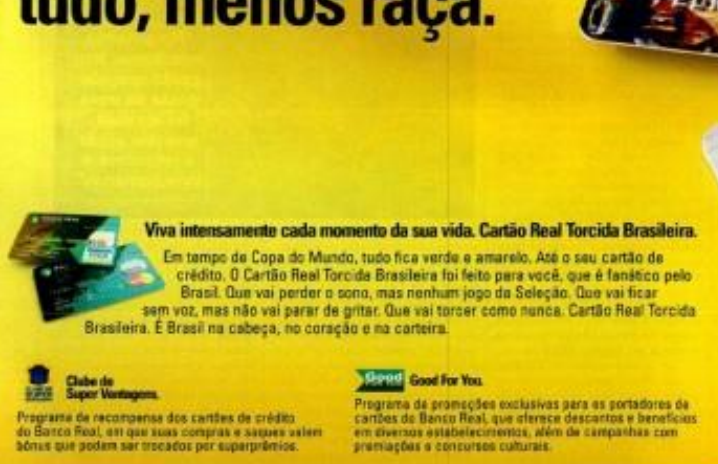

0800144040 
Figura 19 - Veja, dez. 1985
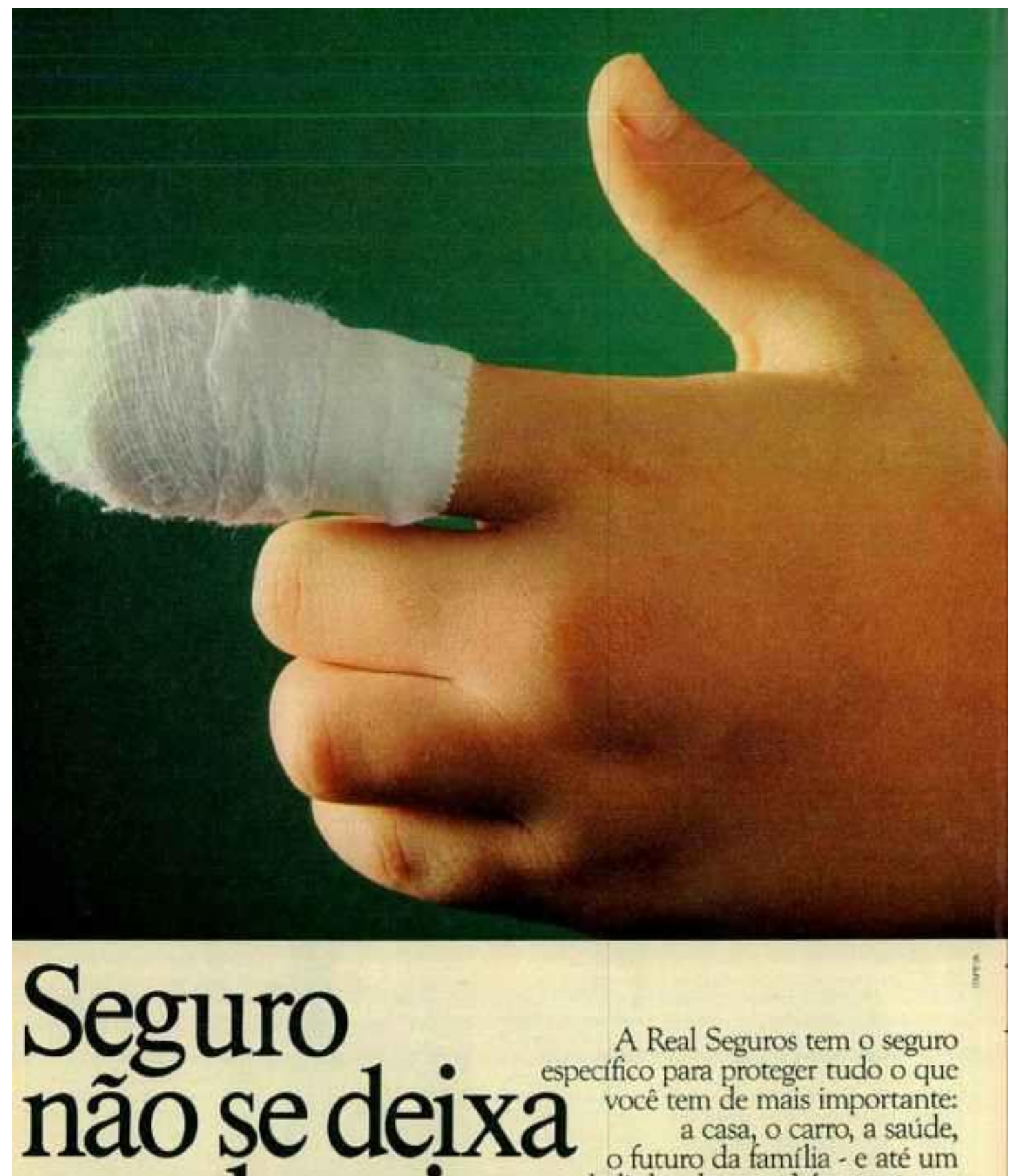

A Real Seguros tem o seguro específico para proteger tudo o que você tem de mais importante: a casa, o carro, a saúde, o futuro da família - e até um

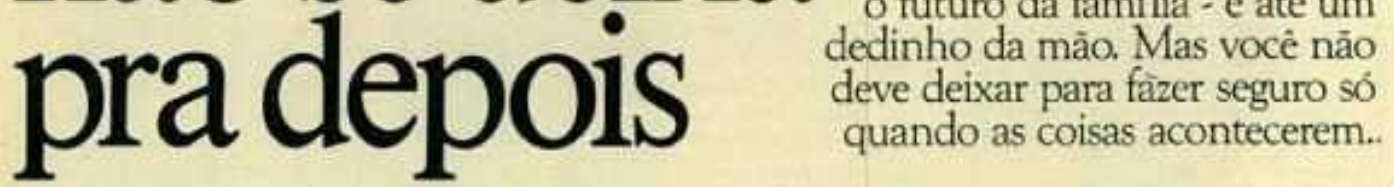
Com o seu corretor de seguros ou em qualquer agència SEGUROS 
Figura 20 - Veja, jun. 1983

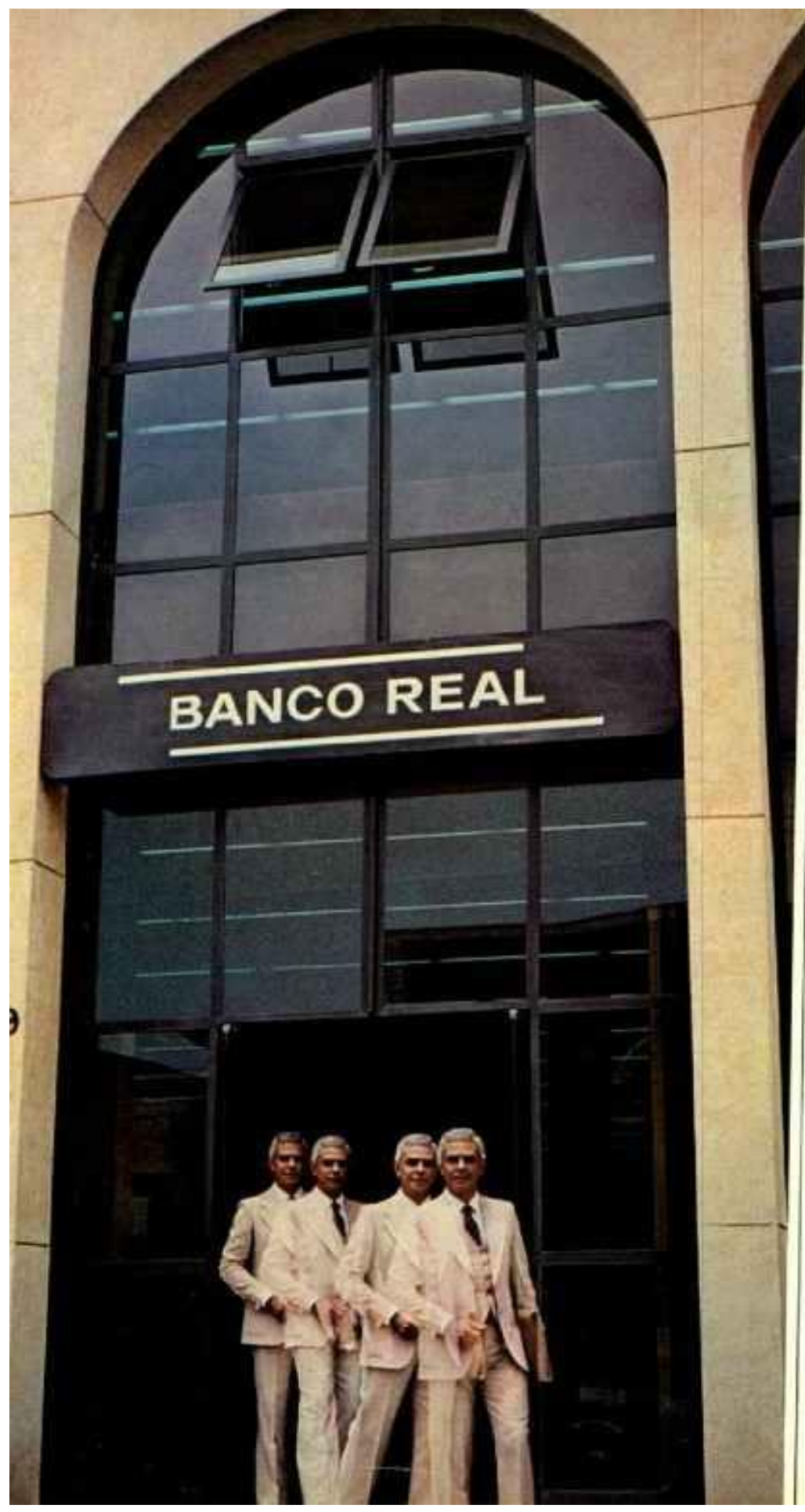

\section{Sistema Realmaster deVantagem Progressiva.}

\section{Um Banco inteiro trabalhando para você.}

- Barico Real coloca a sua disposiçâo o Sisterna Pealmaster de Vantacen Progressiva.

Um sistema de serviços bancánios pioneiro no mercado brasileiro A partir de agora quanto mas produtcs e serviços do Banco Real voce usar, mais oroximo voce va estar do Cbente Realmaster.

Para ganhar dinheiro com isso. Logo de saida vocet iem uma reduçán na taxa de crédio pessoal. que vai aumentando na medida em que voce concentra seus negocios no Banco Real.

Tem também emprestimo sem avasista e ainda ganhta o Cartado Real-para usar o Reaimatic,

descontar cheques em qualquer agéncia do Banco Reale ser identificado no metcado como Ciente Reaimaster

Nào Derca tempo.

o Sisterna Realmaster ce

Vantagem Progressiva esta

esperando por voce em todas as

agèncias do Banco Peal

Entre e converse como gerente.

Afinal vocé lem um Banco inteiro

trabalhando para voce.

Assim, sobra meis tempo e dinheiro

para viver meithor

\section{BANCO REAL}

orianco gue taz mais pcr save cliensises.

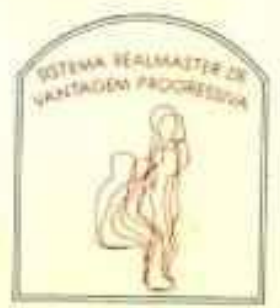


Figura 21 - Veja, jan. 2001

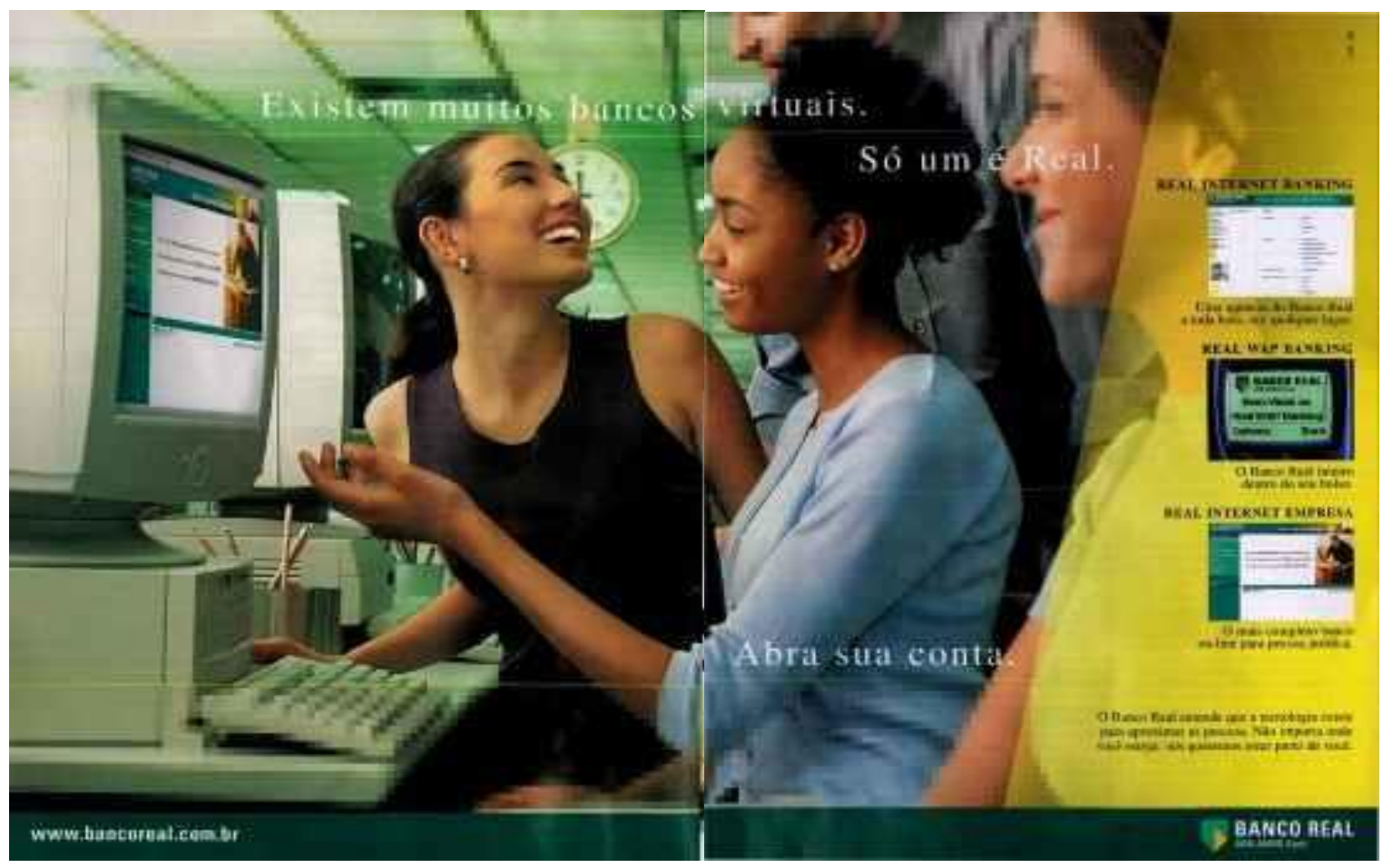


Figura 22 - Veja, jun.1982
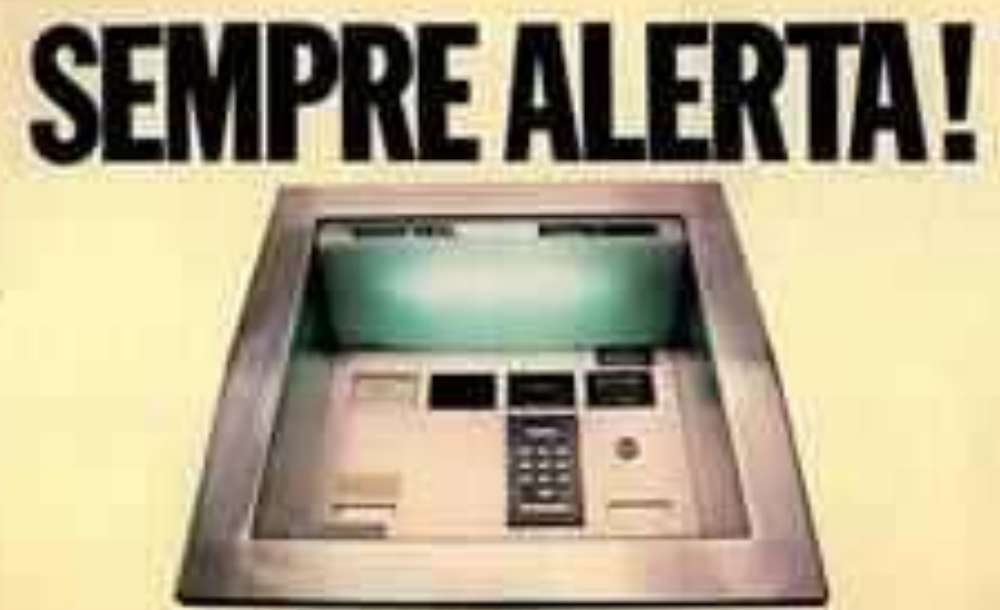

ESTR ACENCA DO BAYCO REAL WUICA FECHA.

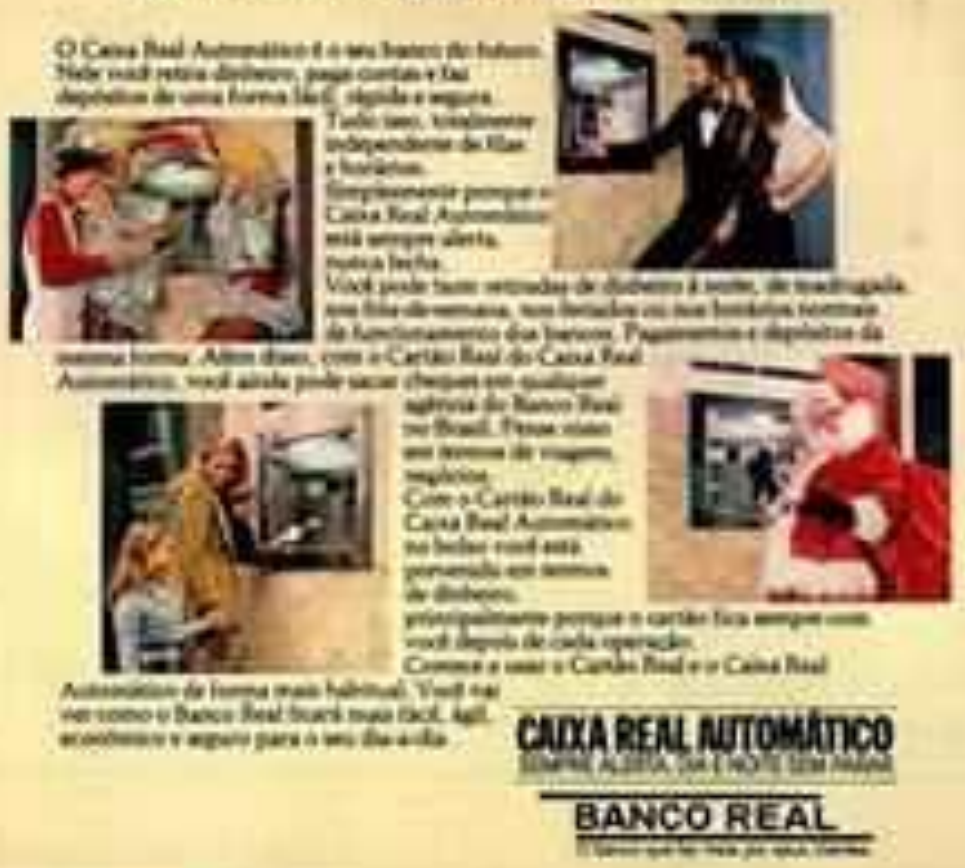


Figura 23 - Claudia, 1984

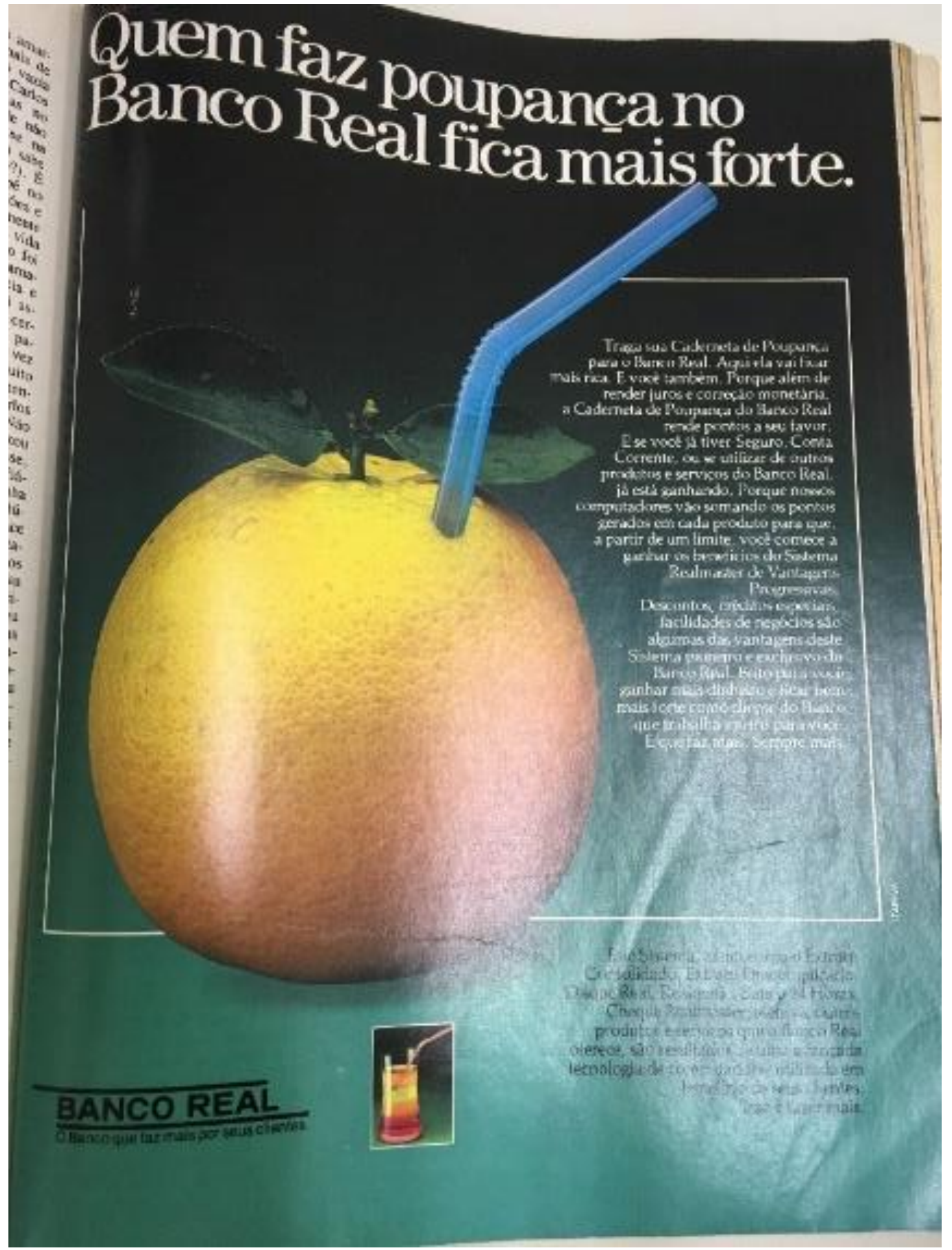


Propaganda utilizada somente para exemplificação (Exame, jan. 1977, p. 50)

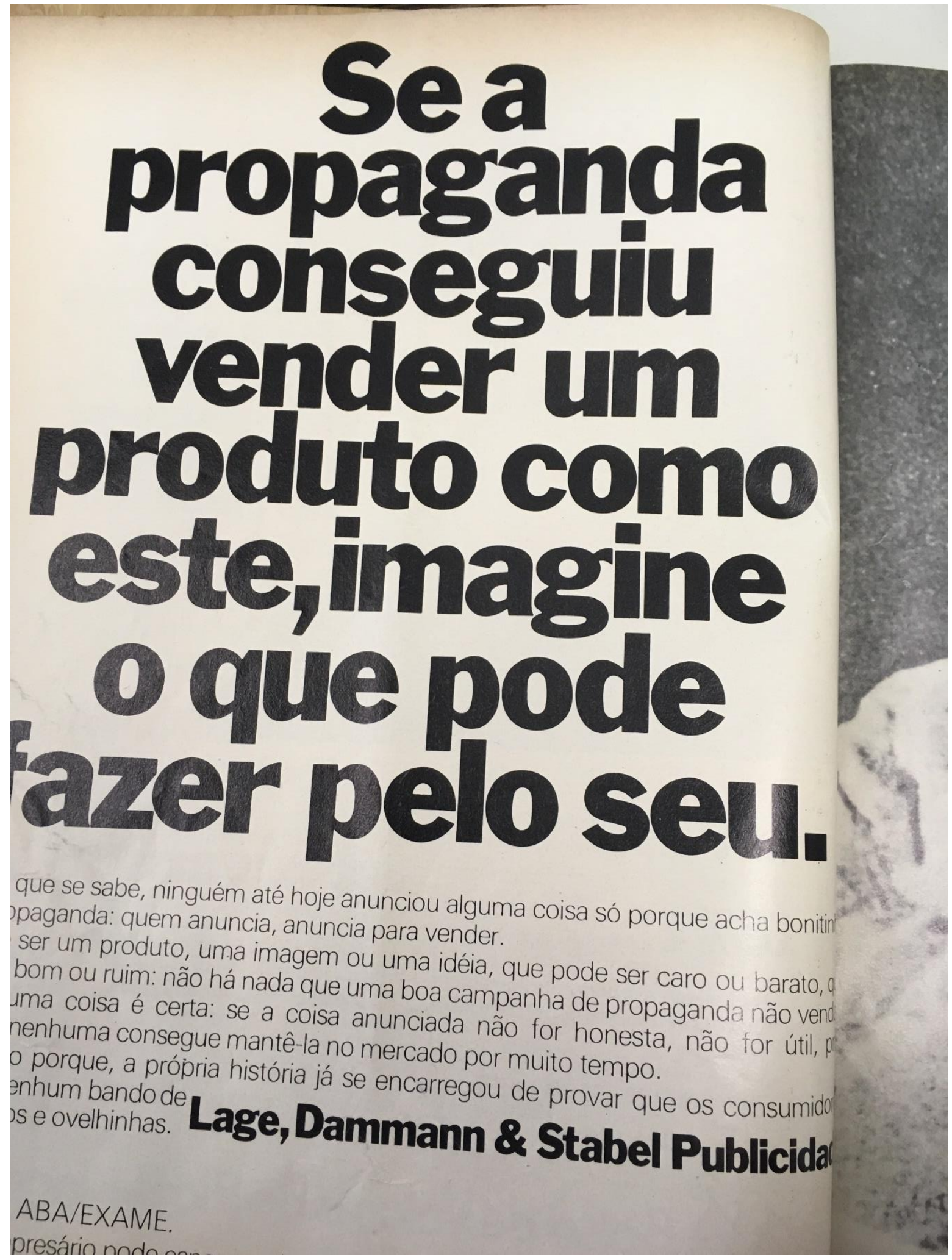


Propaganda utilizada somente para exemplificação (Veja, abr. 1992, p. 88-89)

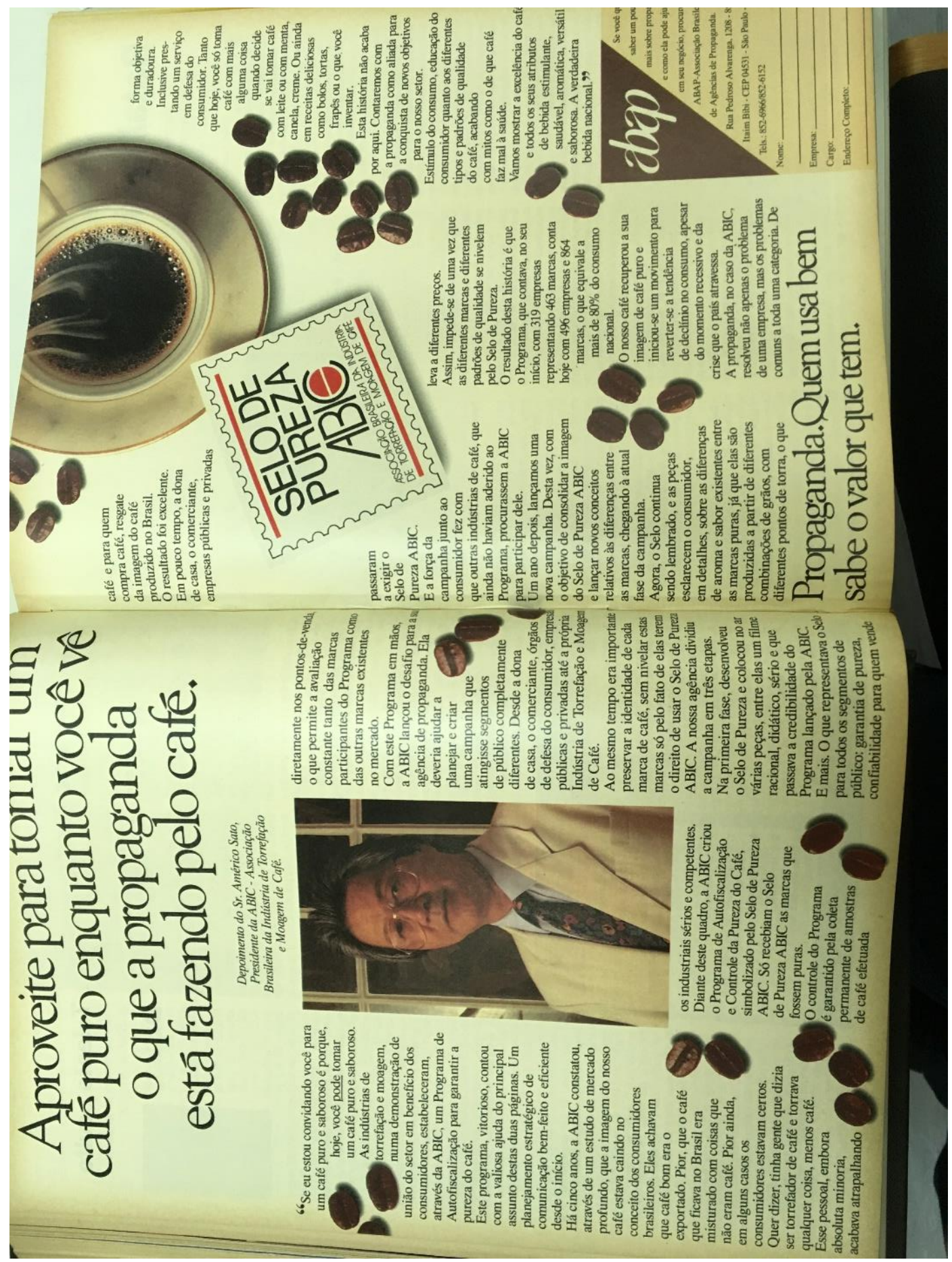


Propaganda utilizada somente para exemplificação (Claudia, ano XXII, n. 251, ago. 1982, p. 226)

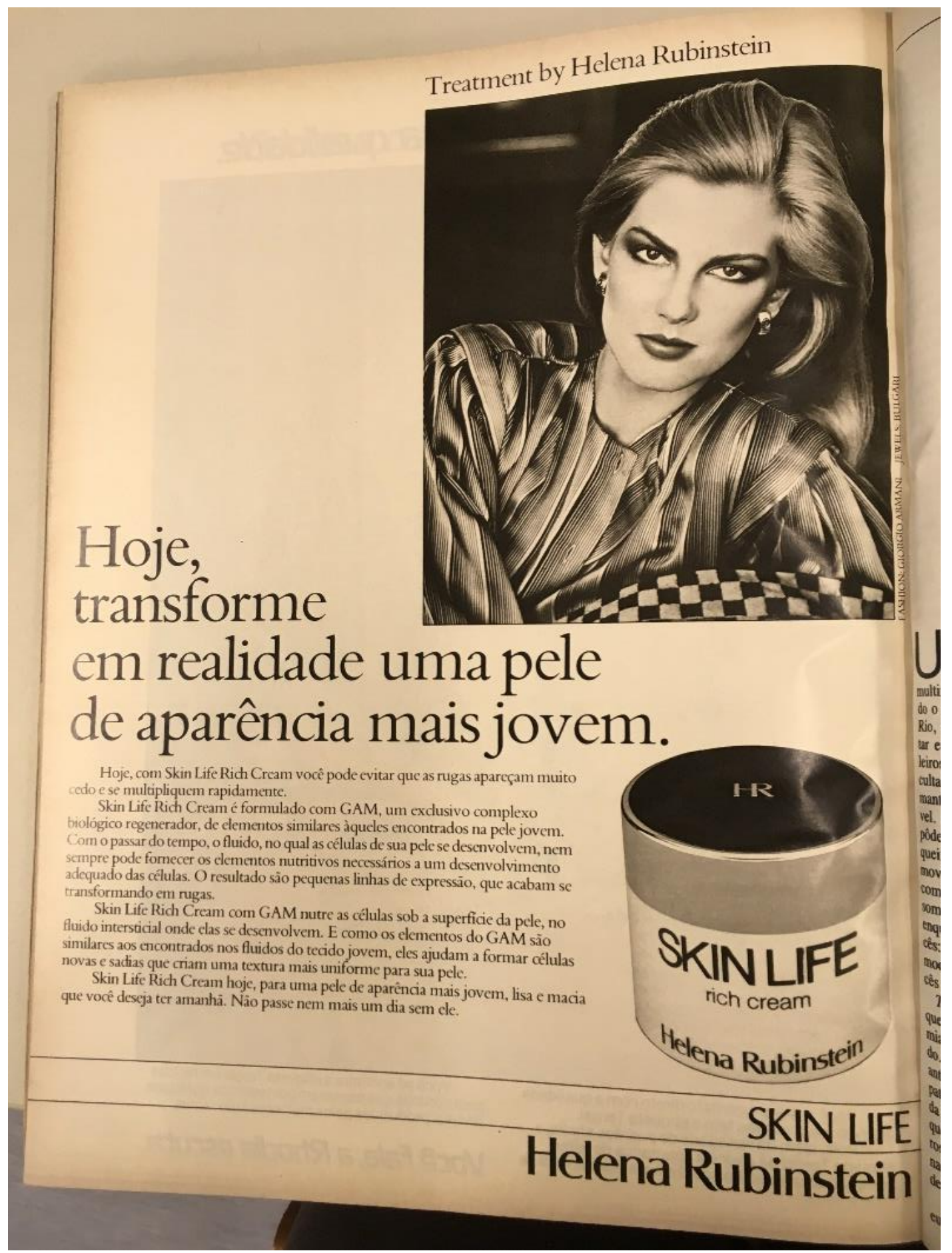


Propaganda utilizada somente para exemplificação (Claudia, nov. 2016, p. 2-3)

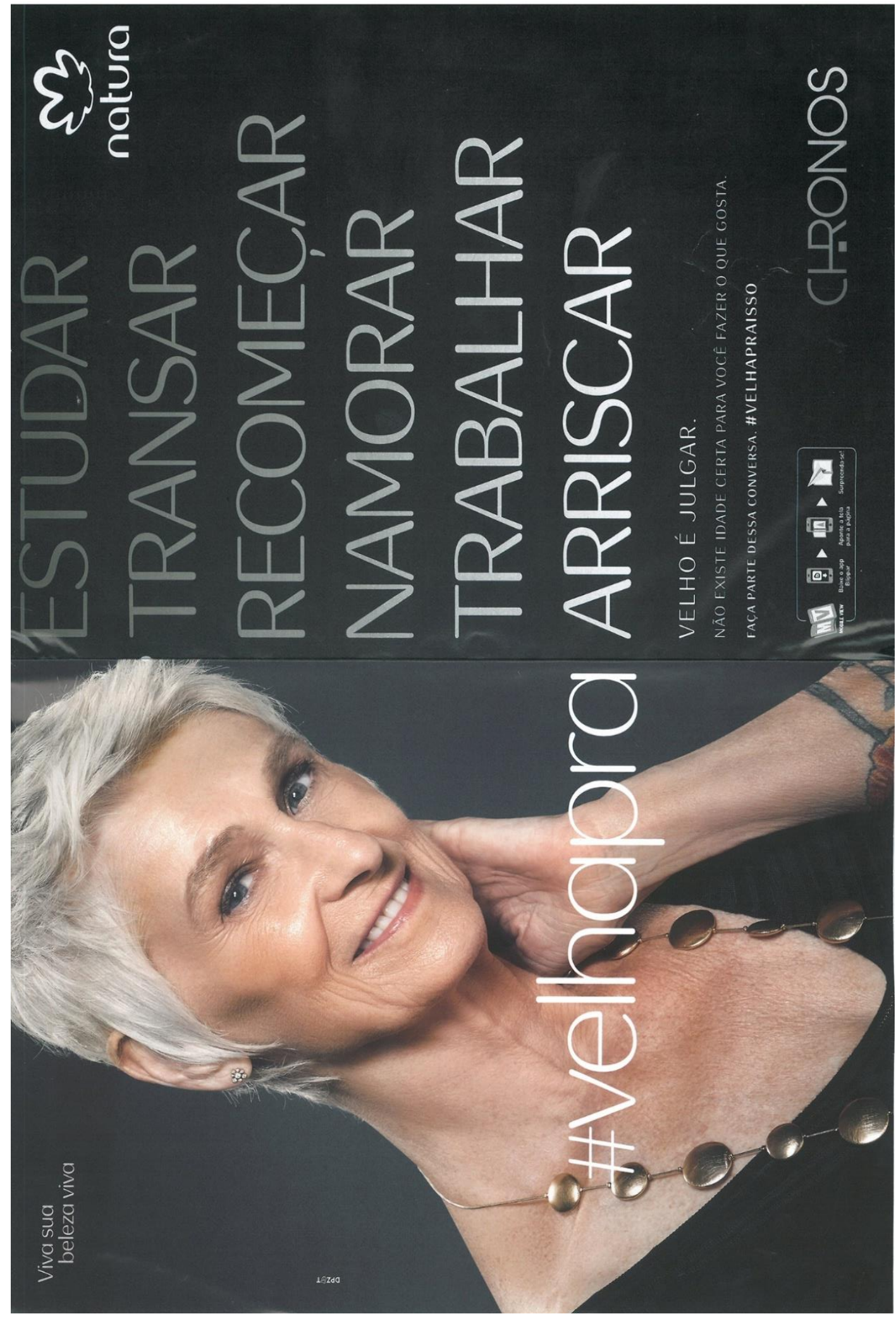


Propaganda utilizada somente para exemplificação (Seleções, jul. 1960, n.222)

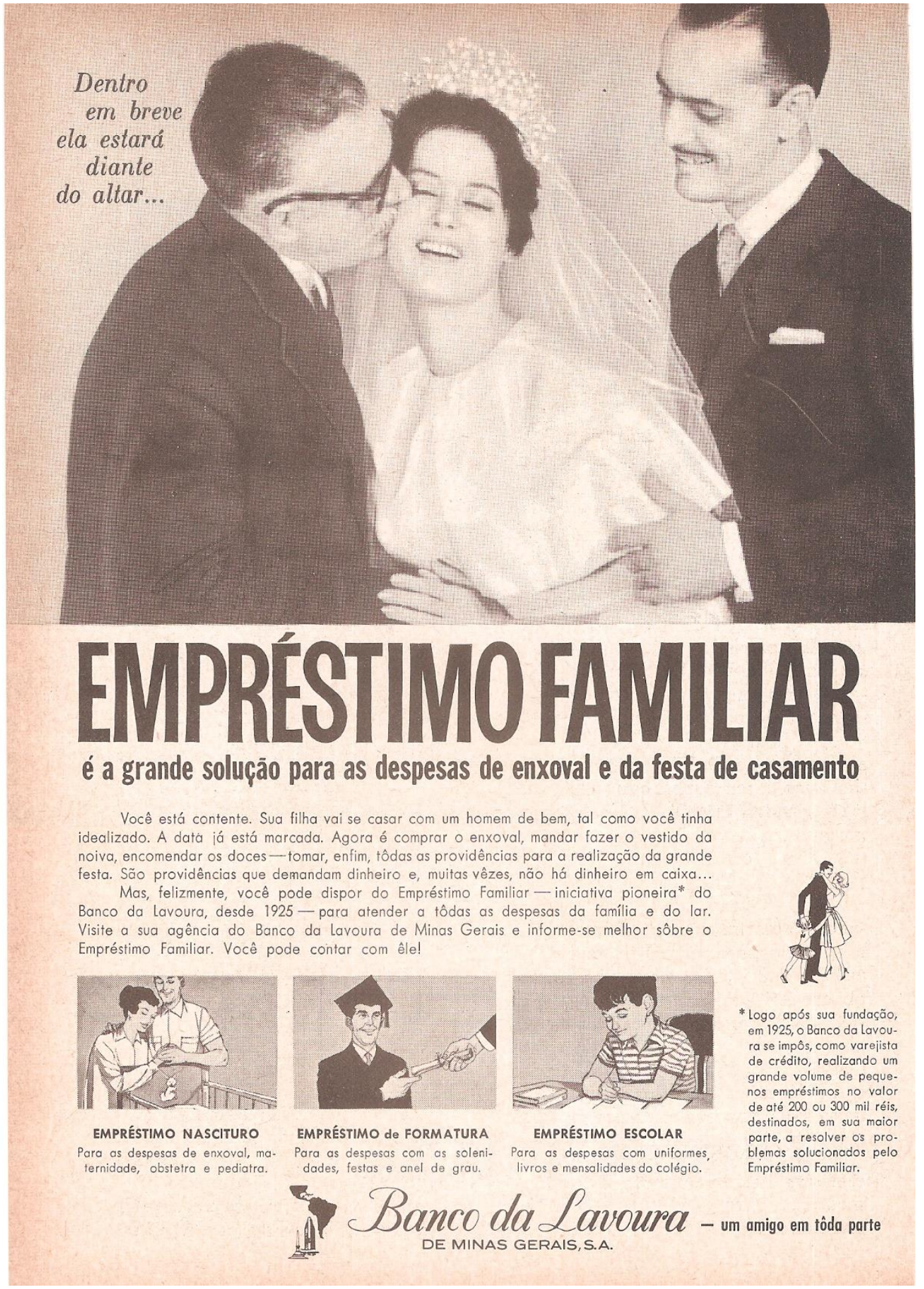




\section{ENTREGA DO EXEMPLAR CORRIGIDO DA DISSERTACÃO/TESE Termo de Ciência e Concordância do (a) orientador (a)}

Nome do (a) aluno (a): LUCIMAR REGINA SANTANA RODRIGUES

Data da defesa: $\underline{26 / 09 / 2019}$

Nome do Prof. (a) orientador (a): MARIA LÚCIA DA CUNHA VICTÓRIO DE OLIVEIRA ANDRADE

Nos termos da legislação vigente, declaro ESTAR CIENTE do conteúdo deste EXEMPLAR CORRIGIDO elaborado em atenção às sugestões dos membros da comissão Julgadora na sessão de defesa do trabalho, manifestando-me plenamente favorável ao seu encaminhamento e publicação no Portal Digital de Teses da USP.

São Paulo, 25/11/2019

$$
\text { mavie L.min 6. U.O. Anelecele }
$$

